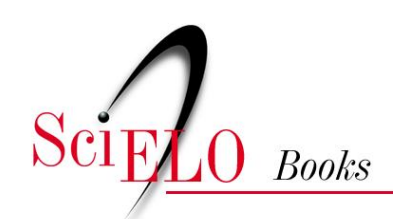

\title{
Observatório da vida estudantil primeiros estudos
}

\author{
Sônia Maria Rocha Sampaio \\ (org.)
}

SAMPAIO, SMR., org. Observatório da vida estudantil: primeiros estudos [online]. Salvador: EDUFBA, 2011, 273 p. ISBN 978-85-232-1211-7. Available from SciELO Books $<\underline{\text { http://books.scielo.org }>\text {. }}$

\section{(9) $(0 \bigcirc$}

All the contents of this chapter, except where otherwise noted, is licensed under a Creative Commons Attribution-Non Commercial-ShareAlike 3.0 Unported.

Todo o conteúdo deste capítulo, exceto quando houver ressalva, é publicado sob a licença Creative Commons Atribuição - Uso Não Comercial - Partilha nos Mesmos Termos 3.0 Não adaptada.

Todo el contenido de este capítulo, excepto donde se indique lo contrario, está bajo licencia de la licencia Creative Commons Reconocimento-NoComercial-CompartirIgual 3.0 Unported. 


\title{
OBSERVATÓRIO DA VIDA ESTUDANTIL
}

\author{
Primeiros Estudos
}


UNIVERSIDADE FEDERAL DA BAHIA

Reitora

Dora Leal Rosa

Vice-Reitor

Luiz Rogério Bastos Leal

\section{$\int_{E D U B A}$ \\ EDITORA DA UNIVERSIDADE FEDERAL DA BAHIA}

Diretora

Flávia Goullart Mota Garcia Rosa

Conselho Editorial

Alberto Brum Novaes

Angelo Szaniecki Perret Serpa

Evelina de Carvalho Sá Hoisel

Cleise Furtado Mendes

Caiuby Alves da Costa

Charbel Ninõ El-Hani

Dante Eustachio Lucchesi Ramacciotti

José Teixeira Cavalcante Filho

Maria Vidal de Negreiros Camargo 


\section{Observatório DA VIDA estudantil}

Primeiros Estudos

SÔNIA MARIA ROCHA SAMPAIO organizadora

Edufba | Salvador, 2011 
(C)2011 by Autores.

Direitos de edição cedidos à EDUFBA. Feito o depósito legal.

Projeto Gráfico, Editoração Eletrônica

Alana Gonçalves de Carvalho Martins

Revisão

Cida Ferraz

Normalização

Lucas Vieira

Sistema de Bibliotecas - Ufba

Observatório da vida estudantil : primeiros estudos / Sônia Maria Rocha Sampaio, organizadora ; prefácio Naomar de Almeida Filho ; posfácio Alain Coulon. - Salvador : Edufba, 2011.

$273 \mathrm{p}$.

ISBN 978-85-232-0778-6

1. Estudantes universitários - Bahia. 2. Estudantes universitários Condições sociais. 3. Ensino superior - Bahia. 4. Universidade Federal da Bahia. 5. Universidade Federal do Recôncavo da Bahia. I. Sampaio, Sônia Maria Rocha. II. Almeida Filho, Naomar de. III. Coulon, Alain.

CDD - 378.098142

Editora filiada à:

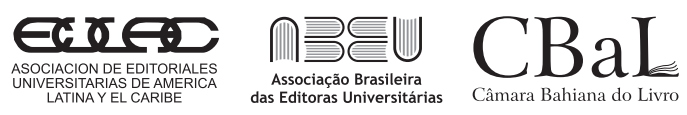

Edufba

Rua Barão de Jeremoabo, s/n, Campus de Ondina, 40170-115,

Salvador-BA, Brasil

Tel/fax: (71) 3283-6164

www.edufba.ufba.br | edufba@ufba.br 


\section{SUMÁRIO}

Prefácio

A VIDA UNIVERSITÁRIA COMO OBJETO DE PESQUISA E

O CAMPUS UNIVERSITÁRIO COMO ETNOPAISAGEM

7

Apresentação

O OBSERVATÓRIO DA VIDA ESTUDANTIL

uma contribuição aos estudos sobre vida e cultura universitária

13

ENTRE A ESCOLA PÚBLICA E A UNIVERSIDADE

longa travessia para jovens de origem popular

27

ESTUDANTES DE ORIGEM POPULAR E AFILIAÇÃO INSTITUCIONAL

53

QUESTÕES CONTEMPORÂNEAS NO COTIDIANO DA UNIVERSIDADE algumas implicações temporais

71

UM NOVO UNIVERSITÁRIO

estudantes de origem popular na Ufba

93

PRECÁRIO, MAS AMOROSO

uma breve discussão sobre a interdição temporária do Espaço Raul Seixas 
VIDA AFETIVO-AMOROSA E VIDA UNIVERSITÁRIA

ambiguidades e contradições

133

MÃES E UNIVERSITÁRIAS

transitando para a vida adulta

145

JUVENTUDE E POLÍTICA

observando a Ufba

169

ACESSIBILIDADE E VIDA UNIVERSITÁRIA

pontuações sobre a educação inclusiva

187

TREINAMENTO EM HABILIDADES SOCIAIS

uma ferramenta útil para atuar em ações afirmativas?

209

O BACHARELADO INTERDISCIPLINAR DA

UNIVERSIDADE FEDERAL DA BAHIA

o que dizem os estudantes?

229

A EVASÃO NA EDUCAÇÃO SUPERIOR

entre debate social e objeto de pesquisa

249

Posfácio

263

Sobre os Autores

269 


\section{Prefácio}

\section{A VIDA UNIVERSITÁRIA COMO OBJETO \\ DE PESQUISA E O CAMPUS UNIVERSITÁRIO \\ COMO ETNOPAISAGEM}

NAOMAR DE ALMEIDA FILHO

Fascinante esta ideia do Observatório da Vida Estudantil (OVE). Traz a marca de uma inovação metodológica no plano acadêmico e demonstra compromisso com a transformação por que passa a universidade brasileira, neste momento em que nos dão asas.

A consolidação de empreendimento institucional tão importante e criativo como este Observatório se revela na produção acadêmica de evidente qualidade científica, apesar de precoce, compilada neste livro. À guisa de introdução a esta rica coletânea de ensaios e relatórios de pesquisa, Sônia Maria Rocha Sampaio, Coordenadora do OVE, articula reflexões, evidências, análises e interpretações em torno de questões pontuais conformadoras de uma cena complexa de produção de conhecimento, compreendida a partir de uma abordagem etnometodológica tributária da matriz teórica do interacionismo simbólico.

Nos capítulos iniciais deste volume, chama a atenção a categoria 'origem popular', utilizada como conceito de diferenciação social capaz 
de integrar as desigualdades econômicas, sociais e políticas do conceito clássico de classe e os aspectos imateriais e simbólicos dos diversos usos da noção de 'pobreza'. Ana Maria Freitas Teixeira, pesquisadora da Universidade Federal de Sergipe, utiliza a metáfora de uma longa travessia para descrever e qualificar o itinerário entre a escola pública e a universidade, cumprido por jovens pobres, em busca de mobilidade social pela educação superior. Ava da Silva Carneiro, mestre em Psicologia POSPSI/UFBA, analisa a adaptação à educação superior dos estudantes de origem popular, construindo afirmação vivencial nos processos de afiliação institucional. Fábio Nieto Lopez, também mestre em Psicologia, traz uma discussão geral sobre a ideia de migração de um interior ao outro, do interior territorial ao interior institucional, focalizando em paralelo algumas implicações temporais das travessias heteroambientais. Matheus Batalha Moreira Nery, doutor pelo Programa de Pós-Graduação em Psicologia (POSPSI/UFBA), aborda a chegada de estudantes de origem popular à universidade, resultado da travessia (metafórica, como vimos), identificando no perfil social e cultural da comunidade discente (transformado pelas Ações Afirmativas) um novo universitário.

Os capítulos que formam o corpo intermediário do volume abordam questões da subjetividade e do cotidiano construídas na experiência de passagem pela universidade, valorizando marcos pontuais do ambiente institucional concreto, dentro de um referencial teórico da cotidianidade. Fábio Nieto Lopez, Sônia Maria Rocha Sampaio e uma equipe de bolsistas de Iniciação Científica da UFBA, analisam efeitos simbólicos provocados pela interdição temporária de um espaço de aprendizagem, o Pavilhão Raul Seixas do Campus São Lázaro. Ana Maria de Oliveira Urpia, também doutoranda do POSPSI UFBA, traça um paralelo entre a experiência da maternidade e a exposição ao novo ambiente, analisa a formação na universidade como transição para a vida adulta e contempla o fenômeno de uma adolescência cada vez mais tardia nas sociedades ocidentais contemporâneas. Rita de Cássia Nascimento Leite, docente da Universidade Federal do Recôncavo da Bahia e uma estudante de graduação abordam os vínculos afetivos e 
as relações amorosas surgidas e cultivadas durante a vida universitária, ressaltando suas ambiguidades e contradições. Finalmente, novamente Sônia Maria Rocha Sampaio (agora com um grupo de ex-alunos de graduação do Instituto de Psicologia da UFBA) observa a constituição de iniciativas de participação da juventude na política estudantil, como parte importante da experiência de vida universitária.

A parte final, mas não conclusiva, deste volume alinha elementos relevantes e pertinentes para definir, mas não delimitar, o espaço epistemológico e metodológico da vida universitária como campo rico, plural e diversificado de investigação científica. Josineide Vieira Alves, docente da UFRB, Letícia Silveira Vasconcelos, integrante do OVE da UFBA e estudantes do IPSI da UFBA abordam a questão das dificuldades de acessibilidade no ambiente universitário, em tese, como conjunto de obstáculos para a plena inserção na vida universitária daqueles que tiveram acesso formal à instituição, restando a esta garantir-lhes o acesso real à universidade. Djenane Brasil da Conceição e Maria Goretti Pontes, ambas docentes da UFRB, formulam uma interessante proposta de utilizar treinamentos em habilidades sociais como complemento ao desenvolvimento de competências necessárias à formação dos alunos participantes em ações afirmativas. Opiniões e atitudes dos estudantes do Bacharelado Interdisciplinar da UFBA são estudadas por Sônia Maria Rocha Sampaio, Lélia Custódio da Silva (integrante do OVE/UFBA) e um bolsista de IC da UFBA focalizando em especial os processos de escolha de uma modalidade curricular inovadora. Finalmente, Georgina Gonçalves dos Santos, pesquisadora da UFRB em parceria com Lélia Custodio da Silva, refletem sobre o necessário duplo enfoque da evasão na educação superior como, simultaneamente, um debate social politicamente relevante e oportuno e um objeto de pesquisa merecedor de inquérito científico rigoroso e competente.

O posfácio de Alain Coulon demonstra a pluralidade e riqueza de ângulos e vertentes com que educadores, cientistas políticos, sociólogos, antropólogos, estudiosos da gestão e outros scholars podem (e assim o têm feito) abordar o tema da vida estudantil na Universidade. 
Apesar desse empenho, longe nos encontramos de superar o potencial criativo da realidade observada. Muitas e diversas maneiras, formatos e estratégias de superação das vicissitudes da vida estudantil encontramse em gestação e em produção; serão certamente identificadas e estudadas no processo de aproximação ao conjunto temático de questões. De fato, é preciso reconhecer que a principal instituição contemporânea do conhecimento e da cultura que, há quase um milênio, ganhou o nome de Universidade, define-se justamente por suas múltiplas facetas. Por este motivo, Clark Kerr (2005) chegou a propor mudar seu designativo para multiversidade.

Não obstante tanta diversidade, ressalta o caráter de transição na formação dos sujeitos desempenhado pela educação superior (ALEXANDER, 2002) e o papel de iniciação na cultura ocidental contemporânea propiciado pela vida universitária (COULON, 2008). Deixemme tomar um exemplo ilustrativo dessa diferenciação. Trata-se das etapas ou modos de escolaridade: primeiro, no nível inicial de educação, tipicamente os alunos estão numa mesma sala, com um mesmo professor. O tradicional tratamento de "Tia” revela a flagrante personalização de relações, com base num vínculo arcaico, tipo familial. Na segunda etapa da formação, nos níveis escolares médios, muda o padrão de educação: os alunos ainda tendem a ter aulas na mesma sala, mas com vários professores. No que se convencionou chamar de terceiro grau, ou nível superior de educação, multiplicam-se os espaços de aprendizagem e os agentes do processo: estudantes mudam constantemente de ambiente físico, contando com vários mestres. Evidentemente, essa diversificação de padrões territoriais e relacionais se faz acompanhar por diferenciação equivalente de produção simbólica, de regras de conduta, de circulação significante, de culturas, enfim. (WOODS, 1999)

Fazendo jus à prerrogativa da crítica no espaço acadêmico, gostaria de comentar que o termo observatório implica uma metáfora por referência a método. Pode-se fazer a distinção ou contraste entre os espaços históricos (ou míticos) da pesquisa científica: laboratório, observatório, campo. O laboratório constitui o espaço do controle da pes- 
quisa científica mediante a artificialização total ou parcial do ambiente experimental, nele realizando intervenções e interferências em maior ou menor grau. O observatório é um dispositivo panóptico no sentido foucaultiano (FOUCAULT, 1996) que implica distanciamento, tendo o observatório astronômico como paradigma, além da capacidade de monitoramento ou sensoriamento global.

Nesta perspectiva, define-se campo como espaço ativo de observação, coleta de dados e produção de fatos. O campo da pesquisa, em franco contraste aos espaços anteriores da ciência, por sua vez, tem sido muito comum nas ciências ditas culturais, em especial na Antropologia. Nesse sentido, campo indica imersão, participação (oposto ao distanciamento) e completa ou parcial falta de controle (oposto ao ambiente experimental). Vêm daí os conceitos metodológicos instrumentais de trabalho de campo, diário de campo etc.

A instituição universitária tem a vida estudantil como elemento gerador de sua dinâmica política, social e simbólica, nas práticas do cotidiano. $\mathrm{O}$ campus é um campo. $\mathrm{O}$ campus universitário constitui um campo de pesquisa. Tem-se reavaliado o conceito clássico de campo etnográfico, referido a ambientes distantes e isolados, como as míticas comunidades "selvagens", preferindo-se, em vez de campo, falar de "etnopaisagens" (APPADURAI, 1996). Portanto, será pertinente e epistemologicamente justificável tomar a universidade como objeto de investigação das ciências e o campus universitário como uma complexa e plural etnopaisagem.

Múltiplas visões para múltiplas questões ou diversas miradas para uma mesma questão fundamental? Canteiro de abordagens etnográficas das tribos universitárias? Ponto de imersão nos novos ambientes institucionais de produção de conhecimento? Lugar de monitoramento necessário e bem-vindo dos processos de afiliação e reconstrução identitária das universidades? Espaço de exploração das fronteiras do cotidiano das instituições hipercomplexas de conhecimento? Mirante privilegiado do mutante panorama cultural, social e institucional da vida em universidades? Tudo isso e muito mais. De fato, ao Observa- 
tório da Vida Estudantil, diz respeito tudo o que se apresentar como digno de interesse do olhar crítico e produtivo da pesquisa social e cultural nessa peculiar invenção chamada universidade, no microcosmo da UFBA e da UFRB.

\section{REFERÊNCIAS}

ALEXANDER, Kern. The Object of the University: Motives and Motivations. In: F. King Alexander \& Fern Alexander (Eds.) The University: International Expectations. Montréal: McGill-Queens University Press, 2002, p. 3-21.

APPADURAI, Arjun. Modernity at Large: Cultural Dimensions of Globalization. Minneapolis: University of Minnesota Press, 1996.

COULON, Alain. O ofício de estudante: a entrada na vida universitária. Salvador: EDUFBA, 2008.

FOUCAULT, Michel. Vigiar e Punir. Petrópolis: Vozes, 1996.

KERR, Clark. Os usos da universidade: universidade em questão. Brasília: UnB, 2005.

WOODS, Peter. Investigar a Arte de Ensinar. Porto: Porto Editora, 1999. 


\section{Apresentação \\ O OBSERVATÓRIO DA VIDA ESTUDANTIL ${ }^{1}$ \\ uma contribuição aos estudos sobre vida \\ e cultura universitária}

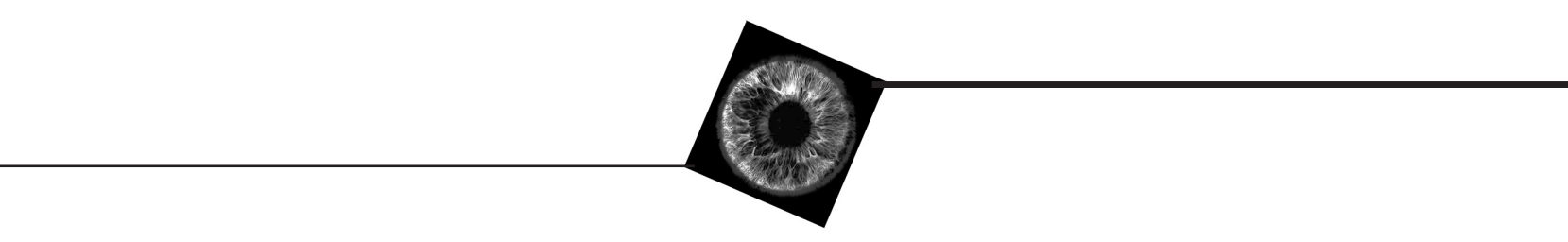

SÔNIA MARIA ROCHA SAMPAIO

\section{INTRODUÇÃO}

Apresentamos aqui ideia, objetivos, metodologia de trabalho e perspectivas atuais do Observatório da Vida Estudantil (OVE), que atua em duas IFES do Estado da Bahia - a Universidade Federal da Bahia (UFBA) e a Universidade Federal do Recôncavo da Bahia (UFRB). O OVE se propõe a acompanhar os diferentes modos de vivenciar a experiência de ser um estudante da educação superior, utilizando-se de metodologia e técnicas de coleta e análise flexíveis no âmbito da pesquisa qualitativa. Seu objetivo é descrever desafios encontrados e aprendizados realizados por esses jovens em seus processos formativos, guiado pelos significados que eles constroem acerca de suas próprias experiências e por uma postura implicada com o contexto em que as pesquisas se desenvolvem: o ambiente acadêmico. Adotar esta perspec- 
tiva, entretanto, significa compreender que os estudantes não constituem um grupo homogêneo e que a diversidade de novos aspectos que afetam a vida estudantil não se limita aos modos por eles adotados para se adaptarem e dar curso à sua vida acadêmica; ela abrange igualmente hábitos e mudanças relativos à saúde, alimentação, lazer, às práticas culturais e sexuais e suas relações com a família e a comunidade.

A universidade brasileira não tem o hábito de dar visibilidade a seus atores. Docentes, gestores, estudantes e pessoal técnico-administrativo, aqueles que constroem o cotidiano acadêmico, não são objeto de estudo sistemático que utilize metodologias sensíveis para expressar aspectos de sua cultura e subjetividade que se desenvolvem no interior da vida universitária. Para melhor desempenhar suas funções e solidificar laços com a sociedade, a universidade carece de um maior entendimento dos itinerários e dilemas enfrentados por diferentes grupos de jovens e adultos que nela convivem ou que dela dependem.

Eleger a relação juventude-universidade como tema de pesquisa é enfrentar um conjunto extremamente diverso de fenômenos complexos. A universidade, historicamente, habituou-se a ver nos estudantes apenas usuários de serviços educacionais. Esteve fechada, por longo tempo, a questões emergentes relativas a esse segmento, falhando em enxergar-se como o espaço-tempo de desenvolvimento onde se dá uma das transições mais importantes da vida de um indivíduo: a passagem para a vida adulta e as tarefas que daí decorrem. Por outro lado, a convivência universitária, pulverizada desde os anos da ditadura militar, foi agravada pela situação de penúria material a que foi submetida essa instituição, impedida de dar atenção a projetos que não fossem voltados estritamente para a formação acadêmica. Aspectos da formação integral da juventude foram negligenciados e hoje pouco se sabe do cotidiano vivido por seus estudantes.

O Observatório da Vida Estudantil surge como linha do grupo de pesquisa - Aproximações: a perspectiva ethno em Psicologia do Desenvolvimento do Programa de Pós-Graduação em Psicologia da UFBA, em 2007. Nos dois anos seguintes, agregando pesquisadores, estudan- 
tes de pós-graduação, de iniciação científica e de extensão em torno da ideia de explorar diferentes aspectos da vida de estudantes universitários, constitui-se como grupo de pesquisa independente, ampliando seu raio de ação para a UFRB, em consequência da aproximação de pesquisadores desta nova universidade, exatamente num momento de expansão e interiorização da educação superior no Estado da Bahia.

\section{A EXPERIÊNCIA FRANCESA DO OBSERVATOIRE DE LA VIE ÉTUDIANTE}

A iniciativa de acompanhar a inserção de jovens em sua nova vida, a partir do momento em que ingressam na educação superior, não é uma novidade. Já em 1989, o então Ministro da Educação da França, cria o Observatoire de La Vie Étudiante que tem como missão fornecer informação, o mais completa, detalhada e objetiva possível, acerca das condições de vida dos estudantes e sua relação com o desenvolvimento de seus estudos. Como projeto institucional amplo, propõe-se, igualmente, auxiliá-los em suas decisões, sem esquecer-se de alimentar a reflexão política e social acerca desse importante segmento da população jovem.

A criação dessa estrutura nacional, disseminada em todo o país, através de observatórios locais e regionais, se dá a partir do extraordinário crescimento do número de estudantes franceses, considerado como verdadeira explosão da população de jovens que ingressavam no ensino superior nessa época. Efetivamente, ao menos do ponto de vista do acesso, a França conseguiu democratizar seu sistema de ensino, contando, já em 2006, com cerca de 2.250 .000 estudantes universitários num país com uma população total de cerca de 63 milhões de pessoas ${ }^{2}$. Ao mesmo tempo, o ensino superior francês conheceu uma multipli-

2 Em dados da Pesquisa Nacional de amostra de Domicílios (PNAD), do mesmo ano, o número de estudantes brasileiros matriculados no ensino superior, era de 5.874.000, representando apenas $10,7 \%$ do total de indivíduos matriculados em todos os níveis de ensino. A maioria das matrículas $(75,5 \%)$ sendo na rede particular. Dados a serem referenciados a uma população total de cerca de 187,2 milhões de habitantes. Mais de $60 \%$ dos que concluem o ensino médio no Brasil não continuam os estudos. 
cação de possibilidades de formação e ampliou sua dispersão geográfica. Esses fatores levaram a mudanças importantes com diversificação cada vez maior das condições de vida e de estudo dessa população. $\mathrm{O}$ Observatório Nacional, que opera em permanente relação com todas as instâncias que produzem ou recolhem informações e conhecimentos sobre a vida estudantil, realiza, a cada três anos, pesquisa nacional sobre as condições de vida dos estudantes. Seus resultados ocasionam aprofundamentos temáticos e regionais a depender da prioridade dos resultados encontrados.

Institucionalizados, do ponto de vista de sua estrutura, os observatórios franceses dispõem de um conselho composto de organizações representativas dos estudantes, de personalidades e técnicos ligados ao ensino superior e representantes comunitários. Possui ainda conselho científico composto por pesquisadores escolhidos nas universidades e centros de pesquisa com a função de desenhar, orientar e controlar a qualidade dos estudos realizados pelo observatório. Tanto o conselho quanto o comitê científico são apoiados no trabalho de uma equipe operacional que assegura o funcionamento cotidiano do observatório.

No quadro do projeto Euro Student, que tem como finalidade comparar as condições europeias acerca das condições de vida dos estudantes, o observatório colabora, desde 1994, com diversos países que realizam pesquisas do mesmo tipo: Alemanha, Áustria, Bélgica, Espanha, Finlândia, Holanda, Inglaterra, Irlanda, Itália, Letônia, Noruega e Portugal. Os temas privilegiados por esses levantamentos são: características sociodemográficas, acesso ao ensino superior, sucesso nos estudos, locais de moradia, auxílios governamentais, custo dos estudos e internacionalização. Os últimos resultados foram disponibilizados, em 2005, no documento Eurostudent Report, Social and Eco-

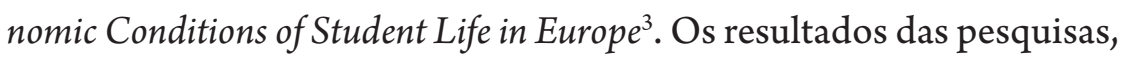
realizadas entre 2005 e 2007, que envolveram, dessa vez, 20 países europeus, serão divulgados brevemente.

3 Disponível em: <http://eurostudent.eu/download_files/documents/Synopsis_of_Indicators_EIII.pdf $>$. 
O Brasil, que ainda se debate com enormes dificuldades relacionadas à democratização do ensino universitário, não dispõe de volume satisfatório de estudos que fundamentem políticas para o suporte a esse público, orientadas para dar consistência aos discursos que apontam para a necessidade incontornável de dotar nosso país de modos de vida acadêmica mais ampla e fértil.

É importante sublinhar que a ideia do OVE resulta de longa interlocução com pesquisadores da Universidade de Paris VIII e fundamenta-se na compreensão da universidade como ambiente de formação, mas, igualmente, espaço de desenvolvimento e transição para a vida adulta. (CAMARANO; MELLO; KANSO, 2006)

\section{O OVE E AS POLÍTICAS DE AÇÕES AFIRMATIVAS}

Nos últimos 10 anos, uma discussão tem sido recorrente no ambiente acadêmico: a chegada às universidades públicas brasileiras de setores sociais antes excluídos. A universidade pública não podia continuar ignorando os milhões de brasileiros pobres que reivindicavam passagem para o que é um direito de todos: a educação superior.

Mas isso não vai se dar facilmente: o debate meritocracia x justiça social continua se dando em diferentes setores da vida brasileira em torno da propriedade ou dos formatos das políticas de ações afirmativas. Entretanto, várias universidades ${ }^{4}$, dentre elas a Universidade $\mathrm{Fe}$ deral da Bahia, implantaram sistemas de cotas, desenvolvendo e aprimorando políticas que ofereçam melhores condições de permanência a

4 Os dados que encontramos diferem quanto ao número exato de instituições públicas federais e estaduais brasileiras que adotam algum tipo de programa de ações afirmativas, seja a reserva (social e/ou racial) de vagas ou o sistema de bonificação. Segundo estudo, divulgado em 2010, do Grupo de Estudos Multidisciplinares da Ação Afirmativa, do Instituto de Estudos Sociais e Políticos (Iesp), ligado à Universidade Estadual do Estado do Rio de Janeiro (UERJ), as ações afirmativas estão presentes em 71,4\% de nossas universidades públicas. A primeira iniciativa data do ano 2000. G1, [S.1.], 30 ago. 2010. Vestibular e educação. Disponível em: <http://g1.globo.com/vestibular-e-educacao/ noticia/2010/08/acoes-afirmativas-estao-em-714-das-universidades-publicas-dizestudo.html>. Acesso em: 30 ago. 2010. 
esse novo segmento de estudantes que, desde o seu ingresso, necessita de apoio para prosseguir e concluir com sucesso o curso de escolha ${ }^{5}$.

Aberto à discussão de diferentes temas que envolvam qualquer segmento de estudantes da educação superior, o OVE privilegiou, inicialmente, uma população específica: os estudantes ingressos na universidade através das políticas de ações afirmativas. $\mathrm{O}$ significativo aumento do número desses estudantes e as novas e saudáveis questões pedagógicas, culturais e sociais, que sua presença provoca no cotidiano acadêmico, trouxeram para o Observatório a demanda de se aproximar de suas realidades e dilemas. No momento em que a universidade brasileira ensaia os passos de uma profunda mudança, mais que nunca é necessário acompanhar as populações de jovens que nela ingressam, especialmente aqueles de origem popular, para compreender o que impacta suas vidas num período que compreende sua transição para a etapa adulta da vida.

Uma preocupação do OVE, que fortalece a relevância da realização de estudos com esse segmento estudantil, é avaliar a qualidade da sua efetiva integração a todos os aspectos relevantes da vida acadêmica, superando a mera inclusão quantitativa. Os resultados desses trabalhos têm ainda a intenção, via divulgação científica e debates qualificados, de auxiliar os gestores a desenhar políticas adequadas que ofereçam a esses estudantes suporte e canais de comunicação ao longo de sua trajetória acadêmica, sistematizando informações úteis para o aprimoramento das políticas de assistência estudantil. Importante lembrar que a universidade brasileira está convocada a empreender uma grande reforma em sua concepção e articulação com o conjunto da sociedade, especialmente com os setores historicamente dela excluídos, o que reforça a relevância do acompanhamento das populações de jovens que nela ingressam especialmente aqueles de origem popular. Avançar nessas discussões constitui importante passo em direção à democratização do bem público universitário e, portanto, parte do direito à cidadania plena.

$5 \quad \mathrm{O}$ ato de criação de duas instituições recentes - Universidade Federal do Recôncavo da Bahia (UFRB) e a Universidade Federal do ABC (UFABC) - já previu a adoção do sistema de cotas. 
Vale sublinhar, entretanto que, inicial e prioritariamente voltado para essa população específica de estudantes, a continuidade dos trabalhos de pesquisa do OVE prevê sua abertura para temas e segmentos da população universitária não privilegiados nessa fase inicial. Sabemos que não apenas os estudantes pobres enfrentam dificuldades para se manter na universidade; a própria escolha do curso a seguir é objeto de insegurança para muitos estudantes que não ingressam pelas políticas de ações afirmativas, bem como os dilemas enfrentados ao longo da aprendizagem das regras que regem o trabalho intelectual requerido para prosseguir no curso escolhido. Além disso, temas como a inserção política, os modos de acesso à cultura e o pertencimento a grupos identitários baseados em cor da pele, gênero ou preferência sexual, são temas contemporâneos e que podem vir a se tornar foco de novos estudos.

\section{AS ESCOLHAS TEÓRICO-METODOLÓGICAS DO OVE}

Inscritas prioritariamente no campo dos estudos qualitativos, de cunho etnográfico, as pesquisas realizadas pelo OVE são tributárias das abordagens fenomenológicas representadas pelo interacionismo simbólico e pela etnometodologia.

O interacionismo simbólico, considerado como uma das fontes da etnometodologia defende a ideia de que aquilo que os atores fazem do mundo social se constitui, em última instância, como objeto essencial da pesquisa nas ciências do homem. Radicais, os interacionistas recusam vertentes teóricas conservadoras que defendem o isolamento dos dados do seu contexto para torná-los mais objetivos, da mesma maneira que recusam o isolamento do pesquisador da cena de observação. Para essa corrente, o distanciamento do objeto é contraditório; somente a familiaridade com os atores legitima a possibilidade de falar sobre eles. (Le BRETON, 2004)

O interacionismo simbólico não concentra seus esforços teóricos em pesquisas sobre noções abstratas, como "sistema social" ou "sociedade", mas propõe se debruçar sobre a concretude das relações interin- 
dividuais, concebendo a realidade como aquilo que se objetiva nas e a partir das relações que se produzem no interior dos grupos e das instituições, orientando seus objetivos, desta forma, para o social en train de se faire.

Reivindicando contato direto, uma relação de imersão no campo e privilegiando estudos que utilizam técnicas que se distinguem por sua flexibilidade e leveza e pelo face a face com os atores, indica a observação participante como sua estratégia privilegiada de pesquisa, servindo-se de entrevistas sob diferentes formas e de documentos pessoais, a exemplo dos diários. Nessa perspectiva, por imersão, o pesquisador torna-se parte ativa do objeto que analisa.

A outra perspectiva teórico-metodológica adotada - a etnometodologia (COULON, 1995; 1996; 2008; GARFINKEL, 1967; SANTOS, 2007), compreende os indivíduos como autores que vivenciam e modificam a realidade ao seu redor, através de suas interações diárias nesse contexto e, ao invés de buscar explicações para seus comportamentos, privilegia as descrições do ambiente de atuação destes atores e as interpretações que fazem acerca dos fatos sociais.

Entretanto, ao adotar a abordagem microssocial dos fenômenos, a etnometodologia não os desvincula de seus contextos ampliados, entendendo que o problema estudado é um fenômeno complexo, onde entra em jogo um grande número de parâmetros habitualmente situados no nível macro. (COULON, 1996)

Outro ponto que justifica a opção pela etnometodologia é o lugar que ocupa a educação como seu objeto de investigação privilegiado. É Coulon (1995) quem vai estabelecer com clareza esta relação, na medida em que a etnometodologia permite apreender os fenômenos que escapam às maneiras clássicas de fazer pesquisa nesse domínio. Para o autor, o fato de tratar de questões de aprendizagem, de fracasso, de exclusão e de interiorização de regras pelos sujeitos sociais aumenta as chances da etnometodologia contribuir com as ciências da educação, apresentando novas e promissoras compreensões acerca desses fenômenos, pois é no cotidiano das instituições educativas, nas malhas das 
interações entre alunos e professores que se constituem as bases das dificuldades vividas por muitos estudantes.

A metodologia proposta está calcada na elaboração de diários de campo por parte de todos os envolvidos nos estudos, em entrevistas compreensivas (KAUFFMAN, 1996) e na observação participante e direta das experiências dos atores em foco, técnicas características da etnografia, alternativa sensível par dar conta dos problemas de pesquisa privilegiados pelo OVE. A abordagem etnográfica é utilizada, com frequência, quando o tema pesquisado envolve fatores sociais complexos culturais, políticos, subjetivos - e quando a proximidade do investigador é condição para acessar, de forma compreensiva, o objeto estudado.

Assim, a postura indicada ao pesquisador, é a de descrever o contexto onde ocorre a produção de sentidos, não se tratando apenas do simples ato de registrar aquilo que se vê em campo como em um inventário, mas de um trabalho rigoroso de analisar e interpretar aquilo que se observa. "A descrição etnográfica é a realidade social apreendida a partir do olhar, uma realidade social que se tornou linguagem e que se inscreve numa rede de intertextualidade”. (LAPLANTINE, 2004, p. 31)

A experiência do campo consiste em uma atitude de distanciamento e estranhamento em relação àquilo que nos é familiar, exige uma suspensão da atitude natural e a observação, mais atenta possível, de tudo o que encontramos e que se relaciona ao foco do trabalho. Dessa forma, a pesquisa etnográfica: "Não consiste em 'comunicar informações' já possuídas por outros, nem em exprimir um conteúdo pré-existente e previamente dito, mas em fazer surgir o que ainda não foi dito, em suma, em revelar o inédito”. (LAPLANTINE, 2004, p. 38)

Através da descrição etnográfica, que possui um caráter de recorte e de concentração da atenção sobre um episódio, num dado momento, podemos apreender os fenômenos sociais enquanto totalidades localizadas, datadas e historicizadas, para chegar a uma descrição, o mais completa possível, dos significados compartilhados pelos membros de um determinado grupo e dos processos de construção desses significados pelos participantes. 
O trabalho do pesquisador, nesse caso, é de natureza não apenas descritiva, como também interpretativa, o que requer um esforço constante para maximizar a possibilidade de apresentar o contexto e as biografias que o compõem, da forma mais próxima da ótica e da subjetividade das pessoas em situação. Para ter acesso a essas perspectivas ou definições que os atores fazem da realidade, ele deve trabalhar no ambiente onde se desenrolam as ações, nas situações "naturais", forma privilegiada de religar essas perspectivas ao ambiente no qual elas emergem. Essas situações "naturais", é bom sublinhar, são o ambiente mais profícuo para a compreensão do fenômeno que se quer estudar, espaço onde estão autorizadas, e são desejáveis, a construção de relações dialógicas entre o self do pesquisador e os selves dos participantes da pesquisa, considerados não como os "informantes" da tradição etnológica clássica, mas “interlocutores”. (OLIVEIRA, 2006)

\section{O OBSERVATÓRIO DA VIDA ESTUDANTIL E SUAS AÇÕES ATUAIS}

O Observatório da Vida Estudantil, atualmente, trabalha em várias frentes de pesquisa, agregando pesquisadores, estudantes de pós-graduação, bolsistas de Iniciação Científica e de Extensão e, mais recentemente, bolsistas de Iniciação Científica Jr. O grupo congrega, atualmente, cerca de 25 participantes que atuam ativamente em seus diferentes projetos

No centro das atenções atuais do OVE encontra-se o projeto Aproximando a Educação Básica da Educação Superior: uma proposta de pesquisa-ação-formação, contemplada como projeto de inovação educacional pela Fundação de Amparo à Pesquisa do Estado da Bahia (FAPESB), em 2009 e que representa um primeiro movimento interinstitucional do OVE, compartilhando com pesquisadores da UFRB a ideia de considerar a vida e a cultura de estudantes universitários como objeto de estudo.

Resultados de pesquisas anteriores do OVE em escolas públicas de Salvador haviam apontado a fragilidade da educação básica em promo- 
ver nos alunos o interesse em continuar seus estudos, ingressando em um curso superior. É dessa forma que surge, dentro do Observatório, a linha de pesquisa $\mathrm{Da}$ Educação Básica ao Ensino Superior, que propõe estreitar os vínculos entre a universidade e as escolas de ensino médio, formula o projeto aprovado pela FAPESB e obtém, assim, recursos para o seu pleno funcionamento, na forma de consumo e capital, tanto para o grupo de pesquisa quanto para as escolas envolvidas. Seu objetivo central é promover vinculação duradoura entre universidades e escolas de ensino médio para estimular alunos, professores, gestores e famílias, a adotarem a ideia da educação superior como projeto de continuidade de estudos. Esse objetivo materializa a missão da universidade de responsabilidade social e implicação com o desenvolvimento da educação no Estado da Bahia.

A investigação realiza-se, experimentalmente, em quatro escolas de porte médio e grande em três cidades: 02 em Salvador, 01 em São Félix e 01 Santo Antônio de Jesus e reúne em torno dela, professores bolsistas de cada uma das escolas que realizam tarefas compartilhadas com a equipe do OVE.

Na perspectiva do Observatório são desenvolvidos ainda 02 projetos de mestrado, 03 projetos de doutorado, 05 planos de trabalho de Iniciação Científica, 04 de Extensão e 16 planos de Iniciação Científica Jr. Os temas dos projetos passeiam pela realidade da vida dos estudantes residentes, relações de tempo e espaço que envolvem estudantes que chegam do interior, condições dos usuários das estruturas de assistência, impacto de programas que visam a permanência de estudantes de origem popular, percurso acadêmico daqueles que ingressam em cursos de alto prestígio e aspectos do desenvolvimento social, político e afetivo de estudantes universitários.

Parte significativa desses trabalhos, finalizados ou em curso, dão corpo a essa primeira publicação do Observatório da Vida Estudantil UFBA/UFRB.

Importante lembrar que a tradução brasileira do livro do Professor Alain Coulon - A Condição de Estudante: a entrada na vida universitá- 
ria. ${ }^{6}$ - pela EDUFBA, em 2008, o curso $A$ atualidade do Interacionismo Simbólico e da Etnometodologia ministrado por ele, nesse mesmo ano, e as visitas que fez ao nosso grupo de pesquisa, à UFBA e à UFRB, consistiram em poderosos catalisadores para os estudos sobre vida e cultura universitária que iniciávamos, propiciando a bolsistas e pesquisadores uma profusão de novas ideias, boa parte materializada nesta publicação ${ }^{7}$.

Além disso, o OVE não teria ampliado e avançado na qualidade de sua produção se, nesses anos, não vivêssemos um momento muito especial na Universidade Federal da Bahia, que amplia a oferta de cursos e de vagas; utiliza a capacidade ociosa de sua infraestrutura, com turmas em cursos noturnos; propõe novos arranjos curriculares e volta-se para a interiorização da educação superior em nosso Estado, em cujo cenário manteve-se solitária por cerca de 60 anos. Essa espécie de canteiro gigante de obras e ideias é uma mina de novas questões para a pesquisa nesse campo. É preciso, então, atribuir às propostas que nasceram na UFBA o crédito pela inovação e o sonho. Foi num feliz encontro, entre o Reitor Naomar de Almeida Filho e o Prof. Alain Coulon, que ideias ainda vagas tomaram corpo e caminharam. O Observatório da Vida Estudantil tem muito a agradecer aos dois.

\section{REFERÊNCIAS}

CAMARANO, A. A.; MELLO, J. L.; KANSO, S. Do nascimento à morte: principais transições. In: CAMARANO A. A. (org.). Transição para vida adulta ou vida adulta em transição? Rio de Janeiro: IPEA, 2006.

COULON, Alain. Etnometodologia e Educação. Petrópolis : Vozes, 1995. . L'Ethnométhodologie . Paris: PUF, 1996.

. A Condição de Estudante: a entrada na vida universitária. Salvador:

EDUFBA, 2008

6 Le Métier d'Etudiant: l'entrée dans la vie universitarie.

7 Esta afirmativa pode ser avaliada pelo número de citações dessa obra feitas pela maioria dos autores que dela participam. 
GARFINKEL, Harold. Studies in Ethnomethodology. Englewood Cliffs, N J: Prentice-Hall, 1967.

KAUFMANN, Jean-Claude. L'entretien compréhensif. Paris: Nathan, 1996. LAPLANTINE, François. A Descrição etnográfica. São Paulo: Terceira Imagem, 2004.

Le BRETON, David. L'interactionnisme symbolique. Paris: Quadrige/PUF, 2004.

OLIVEIRA, Roberto Cardoso de. O Trabalho do Antropólogo: olhar, ouvir, escrever. In R.C. de Oliveira, O Trabalho do Antropólogo. Brasília: Paralelo 15; São Paulo: Editora Unesp, 2006. p.17-35

SANTOS, Georgina Gonçalves dos. Récits d'éducateurs: un regard sur la politique et la pratique de prise en charge d'enfants ayant l'expérience de la rue à Salvador, Bahia Brésil. 2007. Tese (Doutorado em Ciências da Educação). Université de Paris VIII, U.P. VIII, França. 


\section{ENTRE A ESCOLA PÚBLICA \\ E A UNIVERSIDADE \\ longa travessia para jovens de origem popular ${ }^{1}$}

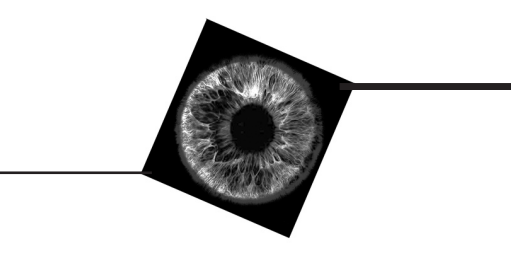

ANA MARIA FREITAS TEIXEIRA

\section{INTRODUÇÃO}

Ao longo do século XX, a noção de juventude ganhou maior visibilidade nas investigações, particularmente naquelas desenvolvidas por pesquisadores das Ciências Sociais e da Educação. Essa multiplicação de análises, ancoradas em diferentes recortes teórico-metodológicos, sobre questões relacionadas à juventude, parece guardar certa vinculação com os desdobramentos produzidos pelas transformações sociopolíticas mais amplas, que afetam transversalmente espaços de socialização,

1 Este artigo é produto de pesquisa que venho desenvolvendo sobre ensino superior e escolarização nos meios populares voltada, mais especificamente, para as transições entre ensino médio e ensino superior. A pesquisa tem contado com o auxílio da Pró-Reitoria de Pós-Graduação da Universidade Federal de Sergipe, através do Programa de Bolsas de Iniciação Científica, viabilizando a participação de duas estudantes do Curso de Pedagogia como bolsistas de iniciação científica do CNPq: Laís S. Santos e Hellen Rejane S. Sacramento e de um estudante do Curso de Ciências Sociais: João Ribeiro S. Júnior, como bolsista voluntário. 
cujos papéis mostravam-se, até então, claramente delineados, tais como a família, a escola e o trabalho. Dito de outra forma: tratar dos desafios e perspectivas da juventude contemporânea significa tratar dos processos de escolarização básica, do acesso ao ensino superior, da inserção no mercado de trabalho, da violência, enfim, de metabolismos múltiplos de desigualdade social, matrizes de seletividade e mobilidade socioeconômica.

Em verdade, enfrentar as questões postas pelo debate atual sobre juventude implica fortalecer a crítica a pressupostos que tendem a naturalizar essa categoria, o que indica a insuficiência de abordagens assentadas simplesmente em critérios cronológicos. Simultaneamente, categorizar "juventude" é tarefa complexa, se consideramos que se trata de arbitrários culturais socialmente elaborados para definir em que dado momento, e mediante quais rituais de passagem, é possível transpor uma etapa da vida em direção a outra. Assim, não há como negar que, em espaços-tempos distintos, são múltiplas as juventudes: "São muitas as juventudes e entre elas sempre há territórios de resistências por força da criatividade [...]”. (NOVAES; VANUCCHI, 2004, p. 11)

Antes definida a partir de padrões etários, hoje ela se refere principalmente ao período "[...] marcado por ambivalências, pela convivência contraditória de elementos de emancipação e subordinação, sempre em choque e negociação" (NOVAES; VANUCCHI, 2004, p. 12), durante o qual o sujeito elabora seu próprio amadurecimento.

A esse respeito Pais (1990, p. 140)2 nos adverte:

A juventude começa por ser uma categoria socialmente manipulada e manipulável e, como refere Bourdieu, o facto de se falar dos jovens como uma 'unidade social', um grupo dotado de 'interesses comuns' e de se referirem esses interesses a uma faixa de idades constitui, já de si, uma evidente manipulação. 
De fato, os jovens, em geral, são tomados nas representações de juventude como um todo homogêneo que compartilha as mesmas situações, expectativas, desejos e problemas. Em que pese a existência de similaridades relativas, é inegável que há diferenças sociais entre eles, o que nos permitiria adotar o termo "juventudes".

Entre similaridades e diferenças, situa-se, igualmente, o que se convencionou chamar de "problemas dos jovens" (arranjar um emprego, enfrentar o vestibular, escolher uma profissão, as drogas, a relação com a família, o sexo etc.), ainda que estes últimos em nada possam ser considerados como um conjunto homogêneo, e mesmo que não se saiba com clareza o que as juventudes encaram como problemas. Apesar disso, podemos dizer que as juventudes enfrentam esses "problemas de jovens" de maneira igualmente heterogênea.

É dentro dessa configuração complexa que nos interessa focar, dentre as múltiplas juventudes, um grupo social em particular: os jovens de origem popular, e um "problema" específico no campo dos debates da sociologia da juventude e da educação, qual seja o do acesso e permanência desses jovens no ensino superior. Isso significa refletir sobre o caminho percorrido entre o ensino médio e o ensino superior, entre o curso médio na escola pública, o vestibular e a universidade. Seguramente, esse caminho não se inicia no momento em que ocorre o ingresso no nível médio, mas se inscreve em toda a trajetória socioeducacional que o antecede, ainda que o ensino médio seja identificado, em geral, como a antessala do vestibular, estágio crucial para o ingresso na universidade.

Além disso, as intensas e múltiplas mutações sociais que marcam a contemporaneidade, comumente chamadas de globalização, têm influenciado nos padrões educacionais, tornando indispensáveis níveis mais elevados de escolarização de modo tal que o certificado de conclusão do ensino médio tornou-se pré-requisito indispensável para quase todas as funções produtivas.

O desafio, contudo, está em superar os entraves relativos ao acesso, permanência e conclusão, nessa etapa da Educação Básica brasilei- 
ra, desafio este revelado quando os dados estatísticos oficiais registram que, da população brasileira jovem de 18 a 24 anos de idade, apenas $36,8 \%$ possuem essa escolaridade. ${ }^{3}$

Somam-se a isso as desigualdades regionais: para esse indicador, o Nordeste registra o percentual de $29,2 \%$ contra $43,8 \%$ para o Sudeste. Se restringirmos a faixa etária ao intervalo entre 15 e 17 anos (quando os jovens deveriam estar cursando o nível médio), as estatísticas apontam que, dentre os mais pobres, apenas 30,5\% frequentavam essa etapa da Educação Básica, em 2008, enquanto entre os mais ricos o índice estava em $70,4 \%$.

Diante desse cenário, privilegiamos em nossa investigação o grupo social composto por jovens de classes populares (poderíamos dizer "jovens pobres"), oriundos de famílias que convivem com limitados níveis de escolarização, baixo padrão de renda, vinculados a ocupações que exigem baixos níveis de qualificação, residentes em bairros periféricos e/ou em cidades afastadas da capital; enfim, longe de deterem a herança do capital econômico e cultural dominante (BOURDIEU, 2001). Para esse grupo, a passagem pelo ensino médio em escolas públicas é um traço relevante, não só como um dos elementos que compõe seu perfil numa ótica quantitativa, mas, sobretudo, em virtude do que significa ser um egresso da escola pública, quando tornar-se estudante universitário é parte dos seus planos de vida. Como, então, esses jovens, parcela de uma tão ampla constelação de estatísticas dos deserdados $^{4}$, que indica o improvável ingresso dessa população no ensino superior público, contradizem esses prognósticos ${ }^{5}$ ?

Se voltarmos aos estudos de Willis (1991) e Boudon (1981), observaremos a importância de compreender alguns aspectos das experiências escolares dos jovens oriundos das classes populares, tais como o papel da história familiar, dos amigos, parentes e vizinhos. Para esses

3 Pesquisa Nacional por Amostra de Domicílios (PNAD, 2008).

4 Poderíamos igualmente refletir sobre a condição de deserdados, considerando as contribuições de Elias; Scotson (2000) sobre outsiders e estabelecidos.

5 Registramos aqui nossa inspiração nos trabalhos de Jean-Pierre Terrail (1990), em especial, Destins ouvriers. 
autores, o valor atribuído por esses jovens à educação e, por conseguinte, ao prolongamento da escolarização formal, resulta da combinação instável entre os riscos e benefícios frente à trajetória escolar e profissional daqueles que lhes são mais próximos.

Não podemos, de fato, esquecer que, em geral, esses jovens carregam uma história familiar de escolarização incompleta, precária e fragmentada, que poderia favorecer entre eles certa resistência à cultura escolar e baixa valorização da educação, fato esse que, ao nosso ver, se constitui numa frágil explicação para as dificuldades que enfrentam para o ingresso no ensino superior.

O que encontramos, ao longo da pesquisa, é que os jovens e suas famílias não parecem desvalorizar a educação, seja por que o mercado de trabalho tem exigido níveis cada vez mais elevados de certificação, seja pela educação ser tomada como um valor em si mesma. Portanto, é preciso cuidado redobrado para não cair na armadilha sedutora e falsa de considerar que as experiências e trajetórias escolares desses jovens estão definidas pelo que poderíamos chamar de "destino de classe", pela situação social de cada família. (TERRAIL, 1990) O jovem assume papel ativo na construção de sua trajetória escolar (e profissional). O sentido atribuído à escola, ao alongamento da escolarização, em que pesem os obstáculos a serem transpostos, vai se construindo no jogo de forças entre investimento e pertencimento, uma tensão que se configura de diferentes formas, conforme os recursos (materiais e não-materiais) disponíveis aos jovens. É nesse movimento que as três dimensões da vida estudantil, mencionadas por Dubet (1998; 2001), quais sejam o sentido de utilidade dos estudos, a integração na vida escolar e a identificação subjetiva com os estudos, se constituem e interferem nos sentidos e relações estabelecidas com o processo de escolarização.

Prosseguindo nessa direção, outro aspecto que, igualmente, não deve ser negligenciado trata do processo de tornar-se um estudante universitário, ou seja, o caminho da afiliação, tal como nos assinala Coulon (2005). Viver a vida de aluno do ensino médio numa escola pública quando se é um jovem "pobre", oriundo de classes populares, pode 
produzir efeitos no processo de afiliar-se ao "ofício de estudante", uma passagem sempre delicada, no sentido etnológico do termo, à medida que implica se apropriar de outro mundo intelectual, que compreende regras e saberes mais complexos que aqueles relacionados ao universo de aluno do ensino médio. Dito em outras palavras, essa passagem implica viver o tempo do estranhamento, o tempo da aprendizagem para, enfim, conquistar o estatuto de membro, no tempo da afiliação institucional e intelectual.

Como assinala Coulon (2005), analisando o caso francês, o processo de apropriação desse mundo ou dessa "vida universitária" mostra-se tarefa mais árdua para aqueles que são de outras nacionalidades, para aqueles que se deslocam de cidades do interior do país em direção a centros mais urbanizados, para os que trabalham. Avançando nessa direção, e tomando a realidade brasileira como referência, consideramos que os jovens de classes populares em geral e, dentre eles, aqueles egressos da escola pública poderiam fazer parte dessa lista. Nessa linha de análise, poderíamos nos servir da imagem dos círculos concêntricos, sob o viés do diretamente proporcional: quanto mais o grupo social se distancia em relação ao centro, aqui entendido como o capital cultural, econômico e intelectual dominante, que tem nas universidades um de seus lócus privilegiado, a tendência é que maiores sejam as dificuldades a serem enfrentadas no processo de afiliação ao "oficio de estudante", pré-requisito central para entrar na vida universitária.

Disso deriva a necessidade de compreendermos o rearranjo de recursos e táticas ${ }^{6}$ constituídos por jovens de origem popular e as nuanças que conformam a questão do acesso e permanência no ensino superior, em especial na universidade pública.

Dados do INEP $^{7}$ relacionados ao Censo Escolar 2005 registram a situação do aluno brasileiro egresso da escola pública em relação ao ingresso no ensino superior. Apesar das estatísticas oficiais registrarem, para o ano de 2005 , que $87,9 \%$ dos jovens matriculados no Ensino Mé-

6 Utilizamos as noções de estratégias e táticas conforme formulação de Certeau (2008).

7 Instituto Nacional de Pesquisas Educacionais Anísio Teixeira, 2005. 
dio brasileiro estavam em escolas públicas, somente $46,8 \%$ dentre eles ingressaram no ensino superior. Por outro lado, dos $12,1 \%$ de alunos matriculados em escolas particulares de Ensino Médio, 51,7\% destes ingressaram no ensino superior público.

Além disso, as taxas de conclusão do ensino médio são preocupantes. Em 2006, a média de conclusão para a região Nordeste não ultrapassou a marca de 44,6\%, considerando-se os alunos matriculados no $1^{\circ}$ ano ${ }^{8}$. Se juntarmos a esse retrato as informações relativas ao ENEM $^{9}$, poderemos nos aproximar de uma radiografia mais detalhada do ensino médio público no Brasil. Dos 2,9 milhões de participantes do ENEM 2008, 56\% concluíram o ensino médio em anos anteriores, são os chamados egressos. Entre os 1,1 milhões de alunos concluintes, a maioria (77\%) era de escola pública. O desempenho desses estudantes na prova objetiva foi de 37,27 pontos, contra 56,12 pontos dos alunos que estão concluindo o ensino médio na rede privada.

Portanto, atravessar o tortuoso caminho do ensino médio público em direção ao ensino superior público significa, para essa população, lidar com as desigualdades socioeducacionais que se evidenciam nessa transição. No caso específico do Estado de Sergipe, esse caminho mostra-se, comparativamente a outros Estados, mais tortuoso, dada a existência de apenas uma universidade pública, a Universidade Federal de Sergipe (UFS).

Assim, nosso artigo se insere nesse campo de discussão, tomando como matéria-prima de análise as narrativas de jovens estudantes universitários de origem popular, matriculados regularmente em diferentes cursos de graduação da UFS, sujeitos da pesquisa cujos dados e reflexões são aqui apresentados. Essas narrativas, recolhidas entre $2007 \mathrm{e}$

8 Para Sergipe, o percentual foi de 41,9\% e, para a Bahia, de 48,2\% (UNICEF, 2009).

9 O ENEM, Exame Nacional do Ensino Médio, foi criado pelo Ministério da Educação, em 1998, como medida de avaliação do desempenho dos alunos do ensino médio. A partir de 2009, o Exame sofreu alterações substanciais, seja na formulação e duração das provas, seja por permitir que a nota obtida seja utilizada como critério único ou parcial de ingresso nas universidades e institutos federais, conforme a deliberação de cada um deles. A nota obtida vale igualmente para a pontuação daqueles que buscam a via do PRoUni (Programa Universidade para Todos) e como certificação de Ensino Médio para os maiores de 18 anos. 
2009 , foram registradas na forma de relatos orais, em que se inscrevem percepções da vida vivida por esses jovens, sobre a ótica de suas trajetórias escolares; a experiência do ensino médio nas escolas públicas; a busca por informações concernentes ao ensino superior e ao vestibular; as táticas que foram capazes de mobilizar para potencializar o ingresso no ensino superior público; enfim, a constituição e reconfiguração do projeto, social e individual, de tornar-se universitário.

Nessa perspectiva, o interesse não está em apresentar resultados que confirmem ou contradigam prognósticos estatísticos. O que se quer obter é "[...] a compreensão dos comportamentos, a partir da perspectiva dos sujeitos da investigação [...]” (BOGDAN; BIKLEN, 1994, p.16), correlacionada ao contexto do qual fazem parte. Assim, as interrogações estabelecidas para a pesquisa se encaminharam para a compreensão dos fenômenos em toda a sua complexidade e em seu acontecer histórico. Ou seja, não se cria artificialmente uma situação para ser pesquisada, mas vai-se ao encontro da situação em train de se faire, no seu processo de desenvolvimento.

As questões balizadoras que nortearam a investigação recaíram, portanto, sobre o escopo de uma abordagem qualitativa, centrada na análise das narrativas dos sujeitos pesquisados e na produção de dados em profundidade. A entrevista semiestruturada foi adotada como principal instrumento, uma vez que o interesse estava exatamente em fazer produzir um discurso (BLANCHET; GOTMAN, 1992). A análise atenta das entrevistas permitiu um mergulho no material produzido e ancorou a possibilidade de uma leitura transversal, com a finalidade de estabelecer pontos de contato e de estranhamento entre diferentes discursos, considerando a impossibilidade de tomar, seja a juventude, seja o grupo social em questão, como um todo homogêneo.

\section{ALGUMAS NOTAS SOBRE A QUESTÃO}

A transição entre os séculos XX e XXI caracteriza-se, conforme as reflexões refinadas de Castel (1999), pelo acirrado e extenso processo 
de "metamorfoses da questão social", trazendo para o centro da cena o problema da integração social, à medida que assinala a urgência do debate concernente à precariedade, vulnerabilidade e exclusão ${ }^{10}$, três elementos centrais que compõem o processo de desfiliação social ${ }^{11}$. Tratase de um processo que atinge transversalmente a sociedade, incidindo com violência redobrada sobre grupos sociais mais vulneráveis, como é o caso dos jovens oriundos das camadas populares, os quais se veem na contingência de redobrar esforços para fugir da condição de "inúteis no mundo", aqueles sem lugar na sociedade e com poucas chances de virem a encontrá-lo.

O último Censo, realizado pelo Instituto Brasileiro de Geografia e Estatística (IBGE), no ano 2000, registrou que havia no país quase 18 milhões de jovens entre 15 e 19 anos, idade regular de alunos do ensino médio, e mais de 23 milhões de jovens entre 18 e 24 anos, idade regular para o ensino superior. Contudo, em 2008, apenas 8,4 milhões de jovens estavam matriculados no ensino médio. Quanto ao ensino superior presencial, havia, em 2007, 4,8 milhões de jovens matriculados, sendo que apenas 1,2 milhão na rede pública; já em 2008, o número de matrículas passa de 4,8 milhões para 5,08 milhões $^{12}$. Além disso, a Síntese de Indicadores Sociais (IBGE, 2007) aponta que os $20 \%$ mais pobres da população brasileira têm em média quatro anos de estudo, enquanto os $20 \%$ mais ricos alcançam os dez anos. Dos jovens estu-

10 Lembramos de que há um forte debate sobre a noção de exclusão, particularmente sobre a exclusão social, que tem sido empregada de modo excessivamente generalizado. Essa generalização resultou na banalização do conceito inicial, forjado nos anos de 1970, e na multiplicação de abordagens. Sobre essa questão ver o balanço apresentado por Estivill (2003).

11 Para Castel (1991), a desfiliação significa perda de raízes sociais e econômicas e se situa no universo semântico dos que foram desligados, desatados, desamarrados, transformados em sobrantes, inúteis e desabilitados socialmente.

12 A expansão do segmento presencial continua perdendo fôlego: cresceu 4,1\%, entre 2007 e 2008, enquanto a educação a distância praticamente dobrou o número de alunos: de 369 mil em 2007 para 727 mil em 2008, um incremento de 96\%. Assim, em 2008, o Brasil contava com um total de 5,8 milhões de universitários, e as projeções do INEP indicavam que a meta de atingir $30 \%$ dos jovens entre 18 e 24 anos matriculados no ensino superior até 2011, como previsto no Plano Nacional de Educação, não será atingida. Em $2008,74,9 \%$ das matrículas no ensino superior estavam na iniciativa privada. 
dantes matriculados nas universidades públicas, apenas $1 \%$ está entre os $20 \%$ mais pobres da população, ao tempo que cerca de $60 \%$ figuram entre os mais ricos.

Vale lembrar que, após um período relativamente longo, as pesquisas, em diferentes campos das Ciências Sociais e da Educação, experimentam certa renovação, no que se refere às análises sobre as chamadas "classes populares". Frequentemente tratadas de modo estereotipado têm sido vinculadas, via de regra, a um conjunto de práticas e comportamentos referenciados a outros grupos sociais, quase sempre numa lógica de oposição negativa, tais como: ausência de consciência, imediatismo, apatia, resignação, círculo de relações sociais restritas, sentimento de inferioridade etc. Assim, a explicação para a situação cultural e social dessa população encontrava resposta rápida na "cultura da pobreza”, formulada por Oscar Lewis, representante do pensamento conservador norte-americano ${ }^{13}$, e legitimadora da ausência dos pobres nos campos educacional e ocupacional. Dessa forma, pouca atenção foi dispensada às classes populares, suas realidades concretas e suas estratégias de resistência, resultando em leituras estigmatizantes ou numa invisibilidade da qual o segmento jovem não saiu ileso.

Contrariando as perspectivas deterministas, o fato é que os entraves de acesso ao ensino superior público têm sido rompidos por um grupo de estudantes pobres que em suas trajetórias escolares ingressam e permanecem nas universidades públicas (BORI; DURHAN, 2000). Quais os caminhos percorridos para fugir da herança de fracasso social e escolar?

Inegavelmente, não é suficiente ter acesso ao ensino superior para que tenhamos assegurada a situação de sucesso escolar, em que pese o debate sobre essa noção, a medida que, ao acesso, se segue o desafio

13 Lewis produziu, ao longo dos anos de 1960, uma série de trabalhos voltados à formulação desse conceito, dentre os quais se notabilizou: Antropologia de la pobreza: cinco famílias. México, Fondo de Cultura Económica, 1961. Muitas foram as críticas dirigidas ao modelo analítico proposto por esse conceito (KOWARICK, 2002). Contudo, ideias dessa natureza tiveram grande influência na concepção de políticas voltadas ao combate da marginalização social e econômica, nas décadas seguintes, reforçando a noção político-ideológica de uma patologia da pobreza. 
da permanência. Como assinala Charlot (1997), a expressão "fracasso escolar", bem como "sucesso escolar", é um dispositivo para traduzir em palavras a experiência, o vivido e a prática, numa tentativa de interpretar e categorizar o mundo social, tratando-se, nesse caso, de uma classificação ampla que redunda polissêmica e ambígua.

Portanto, qualquer afirmativa que vincule o acesso desses jovens ao ensino superior (seja público ou particular) a um cenário indiscutível de "sucesso" nos aproximaria, forçosamente, de uma leitura reducionista, que se difundiu nas análises sociológicas, a partir de certas interpretações das teorias da reprodução em educação. Isso significa dizer que, em que pese o fato do acesso se configurar como êxito para esse grupo, a constituição do que poderíamos chamar de sucesso se vincula à implementação de políticas efetivas de permanência desses jovens na universidade.

A questão é complexa, pois é preciso evitar, também, que as análises recaiam num outro extremo. Ou seja, desconsiderar o peso, ainda que não determinante, que o lugar social ocupado por esse grupo tem, quando se trata das possibilidades e limites em construir uma dada condição juvenil, num cenário em que está em jogo a combinação entre projetos de futuro e resultados imediatos.

\section{O QUE DIZEM OS JOVENS: POSSIBILIDADES E INCERTEZAS NA TRAVESSIA DO ENSINO MÉDIO PÚBLICO}

Falar da presença de jovens originários dos setores populares na educação superior significa, ainda que não seja esse o objetivo central de nosso estudo, tratar das políticas de acesso a esse nível de escolaridade e do jogo de forças que envolvem a democratização da universidade pública, disputa que se explicita, inclusive, nas disparidades entre jovens inscritos e vagas disponibilizadas, bem como nas diferenciações sociais produzidas entre cursos e carreiras. Vejamos: em 2008, foi disponibilizado, no Brasil, um total de 2.985.137 vagas para cursos de graduação presencial, sendo 344.038 destas para instituições públicas (federais, 
estaduais e municipais) e 2.641.099 para a oferta particular. Disso decorre uma concorrência de 7,13 candidatos por vaga na oferta pública e 1,17 na oferta privada ${ }^{14}$.

Na UFS, para o vestibular de 2009, foram ofertadas 4.455 vagas para 25.097 inscritos (concorrência de 5,63); já para o vestibular de 2010, o número de vagas não ultrapassou 4.910 para 28.338 inscritos concorrência de 5,77. (UFS, 2009)

Portanto, tratar desse tema, nos conduz a analisar os processos de mobilização direcionados ao prolongamento da escolaridade, mobilização vivida por esses jovens estudantes, "marcados" socialmente pela origem familiar de baixo poder aquisitivo, escolaridade muito incipiente e detentores de limitado capital cultural hegemônico. Certamente, essas "marcas" estão presentes nesses processos, sob distintas formas e intensidades. Não se trata, portanto, de negá-las, nem tampouco de tomá-las como definidoras de destinos estabelecidos de forma imutável socialmente, tal como destacam com veemência Charlot (1999), Bourdieu (1993) e Castel (2007), dentre outros.

É nessa perspectiva que aqui nos debruçamos sobre as narrativas de seis jovens estudantes universitários - três do sexo feminino e três do sexo masculino -, no intuito de entender como pensam, agem e sentem, quando se trata de refletir sobre os caminhos percorridos em direção ao ensino superior e, particularmente, em direção ao ingresso e permanência na UFS.

Nesse grupo de estudantes, composto unicamente por egressos de escolas públicas, é recorrente, nas narrativas, o fato da passagem pelo ensino médio não ter potencializado a inserção no ensino superior. Se o ensino médio é uma experiência complexa para qualquer jovem, dado que coincide com um período de transições, em várias dimensões individuais e sociais, ele parece ser mais difícil para esses jovens,

14 Se observarmos a evolução da relação candidatos/vaga na graduação presencial, tendo em vista a oferta de vagas em instituições públicas e particulares, no intervalo entre 2002 e 2008, veremos que há um decréscimo geral, mas a desproporção da concorrência entre essas duas ofertas é estarrecedora: enquanto a concorrência por vaga na oferta pública cai de 8,90, em 2002, para 7,13, em 2008, na oferta particular passa de 1,60 para 1,17. (INEP, 2008) 
desafiados a enfrentar as várias lógicas de exclusão e, por que não dizer, o estereótipo de estudante de escola pública, ou seja, aquele que não domina inteiramente conhecimentos básicos e que deve, portanto, se desdobrar para superar as fragilidades e lacunas existentes em sua formação escolar. Vale notar, inclusive, que mesmo a possibilidade de dar continuidade aos estudos, cursando o ensino médio, é vivenciada por alguns deles como uma possibilidade posta em risco, em que pese o desejo, o interesse e o apoio, maior ou menor, do grupo familiar. Esse risco de ter abortada a chance de ampliar sua longevidade escolar é uma situação que se apresenta de modo mais intenso para aqueles jovens do interior, ou seja, aqueles que vivem nas pequenas cidades do interior do Estado, onde a oferta pública de educação nem sempre ocorre nos mesmos moldes daqueles praticados na capital.

Jonas $^{15}$, um jovem de Nossa Senhora das Dores $(70 \mathrm{~km}$ da capital, Aracaju), cujo pai é pedreiro e a mãe, dona de casa, assinala a situação que viveu em seu município de origem:

No ensino médio foi meio complicado, porque eu fiz pelo SOMEM $^{16}$, que era Sistema Modular, então você estudava 3 meses, quer dizer, 3 disciplinas em 3 meses, depois 3 meses já era outras três disciplinas e assim corria muito, muita coisa que não dava. Então, acho que o que marcou no ensino médio foi a dificuldade em tirar ele, né? Porque eu não tinha condições de me deslocar pra outra cidade, então, eu tive que fazer assim mesmo. (Jonas, Matemática, 25 anos) ${ }^{17}$

Essa mesma situação foi vivida por Lara, em Cumbe $(90 \mathrm{~km}$ de Aracaju):

Quando eu comecei o ensino médio na minha cidade havia o projeto SOMEM [...] acho que é Sistema Organizacional Modular de Ensino Médio [...] eu tava fazendo vestibular

15 Os nomes dos estudantes que aparecem no texto são fictícios.

16 Para responder às demandas por educação advindas das comunidades do interior do Estado, o governo estadual implantou, em meados dos anos 1990, o Projeto SOMEM (Sistema de Organização Modular de Ensino Médio) em vários municípios.

17 Todas as transcrições correspondentes às falas dos estudantes foram mantidas em sua forma original. A idade indicada é aquela do momento em que a entrevista foi realizada. 
seriado, inclusive eu fiz uma briga no ano, fui atrás da coordenadora, que ela tinha que avisar o período de inscrição no vestibular, briga assim, no sentido de luta né? Por que os alunos precisavam saber, aí ela disse pra mim assim: Ah! mulher, mas ninguém vai fazer não, eu disse sim, mas a gente tem que dizer! E se eles quiserem? Aí era por módulo, então durante dois meses você estudava Português, Matemática, Biologia, aí pronto, acabava! Depois você estudava outros e o que é que acontece? [...]. Fiz o vestibular seriado [...] só que meu pai resolveu me colocar no segundo e no terceiro ano, numa escola Estadual também, numa cidade vizinha, Nossa Senhora das Dores. Porque ele achou que ia ser melhor, [...] eu ia tá fazendo vestibular, e ele disse que não, que eu tinha que ir e eu aceitei. Ia ser uma nova experiência pra mim. Aí, lá também, eu graças a Deus me dei bem, e continuei o segundo e o terceiro ano. (Lara, Pedagogia, 19 anos)

Entretanto, a fala de Lara nos traz outros elementos. Ela nos indica a demanda por acesso a informações importantes relativas ao vestibular, como o período de inscrição o que, em princípio, se espera que seja objeto de divulgação e mesmo tema de orientação e estímulo aos alunos, por parte de professores e gestores, sobretudo em unidades escolares de ensino médio ${ }^{18}$. Contrariamente, a suposta incapacidade e/ou desinteresse dos estudantes pelo exame e, por conseguinte, pelo ingresso no ensino superior, perpassa o ambiente escolar nas palavras atribuídas à coordenadora.

Diferentemente de Jonas, Lara encontrou suporte familiar para finalizar o ensino médio numa escola pública em uma cidade vizinha, fugindo assim do sistema modular, uma exigência de seu pai, que, mesmo não tendo concluído o ensino fundamental, mostrou-se visivelmente preocupado em ampliar as chances de sua filha para que ela ingressasse em uma universidade pública.

18 A esse limitado grau de informação sobre o vestibular e a formação universitária, que inclusive não é uma característica específica do grupo estudado, Silva (2003) chamou de ausência de um capital informacional. 
Outros aspectos contribuem para alimentar o estereótipo de egresso da escola pública, aprofundando as desigualdades educacionais e intensificando o descrédito difuso quanto à capacidade e possibilidade dessa população dar continuidade à sua escolaridade em níveis mais avançados. Trata-se da recorrente falta de professores em diferentes disciplinas, da defasada infraestrutura e de uma imagem que se difunde amplamente, não sem fundamento, sobre a relativa falta de rigor nos parâmetros de avaliação dos alunos. Ou seja, à medida que a sociedade, em geral, considera que a oferta pública de ensino básico é de má qualidade, num movimento automático, essa má qualidade recai sobre os seus alunos e professores. É possível, então, compreender a baixa autoestima que, por vezes, pode levar esses jovens a desistirem da universidade antes mesmo de enfrentarem o vestibular, numa lógica de autoexclusão. Esse aspecto pode ser facilmente observado, quando Jonas se refere aos colegas da escola pública:

Assim, da turma que eu me formei [refere-se à conclusão do ensino médio] eram pouquíssimos que assim pensavam [refere-se a pensar no ingresso na universidade]. Eu acho que quando eu me formei [no ensino médio], depois disso pra cá eu acho que uns 4 ou 5 [colegas], no máximo, que se formou comigo prestou vestibular aqui. Então, a maioria dizia assim: Ah, porque a UFS é muito difícil de entrar, é muito concorrido, é, só passa quem fizer um cursinho, alguma coisa, tal e tal. (Jonas, Matemática, 25 anos)

Nas palavras de Cláudia, todos esses ingredientes da vida do aluno da escola pública foram mencionados, mas ainda assim ela considera que cursou um bom ensino médio:

Comparando com o de hoje, que eu vejo assim, a realidade de hoje, que não é tão distante assim, eu vejo que era bem melhor que atualmente. Não sei por que, a escola que eu peguei né? O Colégio Tobias Barreto, tinha sei lá, uma qualidade assim, não por que era no centro, mas porque os professores queriam alguma coisa, a direção, sabe? Queria melhorar mesmo a estrutura da escola, foi excelente meu ensino médio. Gostei bastante. (Cláudia, Artes Visuais, 20 anos) 
Cursar um bom ensino médio numa escola pública parece depender de quem são os professores e gestores e, também, da localização da escola: uma escola pública localizada no centro pode, em muito, ser diferente de uma escola pública localizada num bairro periférico da cidade, talvez menos atrativo para professores que "querem alguma coisa" e para gestores que querem melhorar mesmo a estrutura da escola. Cláudia acaba por sinalizar para outra seletividade interna à oferta de educação básica pública, fenômeno fortemente evidenciado, quando se trata de discutir a oferta privada. Outro desafio seria, então, encontrar a escola "certa" para cursar o ensino médio, quando se busca uma vaga na universidade pública.

Mais um enfoque merece nossa atenção. A experiência do ensino médio pode, ainda, se apresentar vinculada à busca de profissionalização que possibilite uma rápida entrada no mercado de trabalho, o que raramente contempla a preparação do aluno para o vestibular, descompasso que pode se acentuar, a depender do curso superior pretendido. Além disso, nunca é demasiado lembrar que, uma parcela significativa da juventude brasileira, não pode ser caracterizada pela moratória em relação ao trabalho. Ao contrário, o direito de gozar minimamente da condição de jovem, para significativa parcela da população brasileira, só é possível porque trabalham. (SPOSITO, 2005):

Bem, eu desde os 13 anos que comecei a trabalhar, trabalhava pra ajudar lá em casa. Então, a maior dificuldade que eu já tive, acho que era assim: era, como é que se diz, desdobrar o tempo pra estudar porque não tinha, muitas das vezes eu ia lá pra o terreninho que a gente tem lá e eu ia $5 \mathrm{hs}$, 6 hs da manhã e 11 hs tava em casa e estudava até 12:30h, então ficava muito cansativo, mas eu nunca me deixei abater por isso não, também eu tirava o fim de semana quase todo pra descansar, porque ninguém é de ferro! (Jonas, Matemática, 25 anos)

De fato, para os jovens das classes populares, a via do ensino profissionalizante mostra-se, não raramente, como um "atalho" para o mundo do trabalho o que, muitas vezes, pode significar retardar ou 
eliminar possibilidades concretas de avançar na escolaridade. Julia nos assinala essa vantagem relativa da profissionalização, quando se trata de "entrar" na universidade:

O médio eu fiz técnico. Fiz magistério. Por imposição de minha mãe [...] Ele se torna muito técnico, você não vê nada para o vestibular, praticamente nada. Física, química, matemática, só o ensino direcionado à criança [...]. Por imposição de minha mãe. Minha mãe dizia: Primeiro que eu tinha cara de professora (risos). E segundo, que ela tinha a concepção que professor não ficava desempregado. [...]. Aí eu fiz o Magistério. (Julia, Letras Francês, 28 anos)

Para preencher a lacuna da formação básica, há uma forte demanda pelos cursinhos pré-vestibulares, estratégia bastante generalizada entre os egressos do ensino médio. Entretanto, a maior parte da oferta de cursos preparatórios para o vestibular implica em custos, o que restringe a possibilidade de lançar mão desse artifício. É preciso, então, partir em busca da oferta gratuita, seja ela pública ou não, para fazer face à lógica de seletividade ${ }^{19}$. $\mathrm{O}$ intuito está em tornar-se mais competitivo na disputa por uma vaga e isso implica em outros tantos esforços que vão desde pagar cursinhos com mensalidades mais baratas e compatíveis com as possibilidades financeiras concretas e, frequentemente, realizados no período noturno, até disputar uma vaga em cursos preparatórios oferecidos gratuitamente. Tal como nos indica Zago (2006), as desigualdades também se explicitam nas possibilidades de formação suplementar.

19 Vale ressaltar que se tem multiplicado em todo o Brasil a organização de cursinhos prévestibular populares, sob diferentes condições de estruturação: vinculados a secretarias de Estado, a universidades públicas e privadas, como a ações de ONG’s (Organizações Não-Governamentais), vinculados às ações pastorais da Igreja Católica e de outras vertentes religiosas, propriamente comunitários, com base no trabalho voluntário, e vários outros arranjos. Trabalhos na área da Sociologia das Desigualdades Educacionais têm suscitado análises que apontam para a possibilidade de considerar essas iniciativas como uma estratégia de classificação, reclassificação e/ou mobilidade social das classes populares. 
Joel, o único da família ${ }^{20}$ de sete filhos a ingressar no ensino superior e também originário do interior do Estado, da cidade de Capela (70 km de Aracaju), indica em sua fala a relação entre as fragilidades em sua formação, o ensino médio público e a importância do curso prévestibular:

Mas eu tive muitas deficiências no ensino médio, sem dúvida alguma, tanto por causa da minha postura, quanto da própria estrutura da escola. Eu acho que assim, o que eu mais reclamo dos meus professores é o tradicionalismo didático [...] No ensino médio, eu acho que não foi tão sólida a minha formação, a não ser em algumas matérias específicas, como história e português e literatura. [...] Eu nunca aprendi a estudar, você aprende conteúdo. Então, coisas que hoje eu acho que a gente deveria aplicar no ensino médio que são aplicadas aqui, como fazer resumo, fichamento de texto, a gente deveria aprender no ensino médio. $\mathrm{O}$ curso pré-vestibular contribuiu mais do que a escola para eu passar no vestibular, não só em termos de conhecimento, mas realmente de adquirir a dimensão do que é o vestibular, do que é uma prova, de como responder uma prova, de como ler questões, interpretar questões. Eles foram mais focados no vestibular, então, em termos instrumentais mesmo, ele me ajudou mais a passar no vestibular. (Joel, Ciências Sociais, 20 anos)

Jonas, que tentou vencer a barreira do vestibular por quatro vezes consecutivas, nos oferece sua experiência, certamente semelhante à de muitos outros jovens como ele:

Eu vim da camada popular. Então, eu não tenho quem me dê a mão, eu tenho que correr atrás por mim. Eu sempre estudei com objetivo. [...] por meus pais não ter instrução e nem nada, mas eles nunca deixaram de me incentivar a ir à escola... Então, eu sentia aquela vontade de, de retribuir tudo que eles estavam fazendo por mim. Então eu sempre

20 Os pais de Joel não ultrapassaram a barreira do ensino fundamental incompleto e, dentre os seus seis irmãos mais velhos, apenas um possui o ensino médio completo, trabalhando como feirante com o pai, enquanto os outros cinco também não concluíram o fundamental. 
corri atrás, sempre tive desejo de, como é que se diz, de progredir, né?![...] No ensino médio o que eu achei que não foi tão bom, foi a correria porque corria bastante pra que eles [os professores] dessem tempo de dar todo o assunto, tal. Aí foi o que complicou mais, você não via um assunto bem mastigado, você não tinha esse tempo de tirar uma dúvida bem mastigada com os professores. Eles tinham que correr pra dar esse assunto. Eu fiz, eu fiz em cursinho, teve um ano que eu fiz um cursinho Pré-Seed para entrar aqui na Universidade, só que eu não consegui, mas eu, teve assuntos que eu vim aprender nesse Pré-Seed, que eu nunca tinha visto no ensino médio porque os professores não davam os assuntos, não tinham tempo. (Jonas, Matemática, 25 anos)

Julia, que também se submeteu ao vestibular na UFS por quatro vezes até obter êxito, também passou pela experiência do Pré-Seed:

Eu fiz o pré-vestibular do Governo (Pré-Seed). Foi o primeiro ano que eles ofertaram lá ${ }^{21}$, em 2005. Eu demorei muito tempo para entrar na Faculdade, se tivesse entrado logo após de ter concluído o Ensino Médio, eu já teria me formado. (Julia, Letras Francês, 28 anos)

O que os estudantes identificam como Pré-Seed é o Programa Pré-Universitário da Secretaria Estadual de Educação de Sergipe, uma oferta pública estatal, mas que exige disputa de uma vaga, em um dos trinta polos, mediante provas de Português, Matemática, Geografia, Física, Biologia, Língua Estrangeira, Química e História, abrangendo conteúdos dos programas referentes às $1^{\mathrm{a}} \mathrm{e} 2^{\mathrm{a}}$ séries do Ensino Médio. Em 2009, foram oferecidas 4.550 vagas, tendo sido registradas 10.931 inscrições ${ }^{22}$.

21 A estudante se refere ao município de São Cristóvão, a cerca de $30 \mathrm{~km}$ da capital do Estado, onde está instalado o campus central da UFS.

22 É provável, que a quantidade elevada de inscritos, esteja relacionada ao número de estudantes que passaram pelo Pré-Seed e obtiveram aprovação nos vestibulares de 2009. Segundo dados da Secretaria de Educação do Estado de Sergipe foi registrado um total de 2.242 aprovações, sendo 1.179 no vestibular da UFS (presencial e a distância) e 1.603 em outras instituições de ensino superior. 
Lançando um olhar panorâmico sobre as trajetórias desses jovens, as lacunas significativas na formação deixadas pela passagem pelo ensino médio público; a busca por possibilidades de formação suplementar; a combinação entre trabalhar e estudar; o envolvimento familiar, muitas vezes limitado no plano material, mas de força inegável no plano subjetivo, e as repetidas reprovações no vestibular, poderíamos dizer que há uma tendência a desafiar o inverossímil, o improvável. Um desafio dessa natureza exige uma significativa mobilização de si mesmo (SCHWARTZ, 1987) em direção ao objetivo de tornar-se universitário, entrar numa universidade pública, seja por força das condições materiais, seja por identificar o ensino superior público como de melhor qualidade e reconhecimento social, e estar disposto a permanecer no desafio de manter-se universitário.

Trata-se de um projeto individual construído - ou destruído socialmente, do qual participam, em maior ou menor proporção, de modo mais ou menos positivo, as relações estabelecidas na família, na escola, junto aos amigos e colegas, os professores. Entretanto, em que pese o papel fundamental dessas relações e heranças diversas e/ ou adversas, capazes de potencializar, sob lógicas distintas, trajetórias, práticas e táticas que desafiam as estatísticas, é preciso não esquecer e, ao menos, indicar aqui outros ingredientes que julgamos importantes à análise, tais como: a susceptibilidade desse grupo social às conjunturas políticas, às práticas democráticas defendidas pela sociedade civil, às políticas públicas e aos aspectos estruturais que interferem nesse longo e sinuoso trajeto.

\section{PALAVRAS FINAIS}

Chegar ao ensino superior em nada se configura como algo "natural" para esse grupo, diferentemente do que se observa nas classes médias e intelectualizadas. (NOGUEIRA; ROMANELLI; ZAGO, 2003)

Em verdade, as desigualdades de acesso são continuamente reescritas na trajetória escolar desses jovens. Desigualdades reiteradas no 
momento em que se dá o ingresso, sobretudo nos primeiros períodos do curso de graduação, quando o enfrentamento de exigências institucionais e intelectuais mais complexas - o processo de tornar-se estudante assinalado por Coulon (2005) - vão esbarrar na história socioescolar desse grupo e evidenciar o movimento entre escolha e adaptação.

Ainda assim, não há dúvida alguma que entrar na universidade representa uma vitória, nas palavras desses jovens, tal como nos disse Milton (23 anos), estudante de Matemática:

Eu comecei a repensar meus conceitos, a dar uma estudada e para mim a maior vitória foi quando eu passei no vestibular, apesar de ser um curso baixo (refere-se à baixa concorrência por vaga, quando comparado a outros cursos), simples, que não depende assim de tanta inteligência assim para passar no vestibular, e querendo ou não, é vestibular [...].

Trata-se, depois de tantos obstáculos, de uma vitória, uma conquista individual, familiar e do grupo social, ainda que o depoimento acima evidencie certa depreciação de si mesmo quanto à capacidade de ser aprovado e mesmo uma tentativa de explicar o resultado obtido pela desvalorização relativa do curso. Mas, por outro lado, encontramos também aqueles que, mesmo considerando a aprovação no vestibular uma vitória, a identificam com o que poderíamos chamar de 'vitória sob condições', ou seja, uma conquista que só se consumará tendo sido asseguradas condições concretas para realizar o curso. Joel indica claramente a angústia frente à possibilidade de ter a conquista da aprovação arruinada pela ausência de condições de permanência:

$\mathrm{Eu}$ achei que eu ia passar quando eu fiz a prova. Quando eu saí da prova eu achei que eu ia passar. Então, não foi surpresa! E eu estava mais angustiado se eu passasse. Como que eu faria para conseguir continuar estudando, para ir à Aracaju, como é que eu faria, onde eu moraria? A minha maior notícia não foi passar no vestibular, minha maior notícia foi depois: de que eu tinha sido aprovado para o programa de residência [residência universitária]. Para mim foi mais importante. (Joel, Ciências Sociais, 20 anos) 
Refletir sobre esse cenário nos leva a uma velha, mas sempre atual constatação: longevidade escolar e retardamento do ingresso no mundo do trabalho são prerrogativas de uma parcela restrita da população brasileira. Logo, exercer algum tipo de atividade remunerada para assegurar e/ ou contribuir com o orçamento familiar, sublinha a sobrevivência material como traço comum na vida dos jovens aqui considerados. Apesar da UFS ser uma universidade pública, os custos para manter-se estudando não são irrelevantes. Encontramos, assim, nos depoimentos registrados, ocupações como balconista, recepcionista, vigia. $\mathrm{O}$ tipo e as condições em que se desenvolvem essas ocupações produzem reflexos na condição de estudante e na constituição das carreiras universitárias.

Diante disso, os estudantes buscam formas de remuneração que possam minimizar esses reflexos, em grande parte negativos, sobre a formação universitária. Sendo assim, a obtenção de bolsas de monitoria, bolsa-trabalho e bolsas de iniciação científica, mostra-se uma alternativa importante. Desenvolvendo essas atividades, eles têm a oportunidade de conviver com horários mais flexíveis e ficar mais tempo envolvidos com as atividades acadêmicas, um importante dispositivo para, além de permanecer na universidade face às adversidades materiais, "entrar" na vida universitária (COULON, 2005), apropriar-se de um mundo intelectual e institucionalmente mais complexo, compreender e fazer uso dos meandros que envolvem as regras e suas práticas, transitar num universo de relações mais amplo e múltiplo, em sentidos, valores e condutas.

Refletindo, por fim, sobre o painel que buscamos apresentar neste trabalho, evidencia-se que as desigualdades socioeducacionais entre os estudantes não são eliminadas pela entrada de jovens das classes populares na universidade, como nos assinalam Bourdieu e Champagne (1993), Duru-Bellat (2003), dentre outros pesquisadores. Procuramos, assim, chegar mais perto da condição de estudante experimentada por esses jovens, de seus percursos formativos, de como a herança do improvável se reverte em alongamento da escolarização, na expectativa de 
melhor responder às indagações sobre quem são os estudantes, quais trilhas por eles percorridas para atravessar o caminho incerto entre a escola pública e a universidade, e, então, colocar em debate os novos e velhos impasses e contradições da educação brasileira.

\section{REFERÊNCIAS}

BLANCHET, A; GOTMAN, A. L'enquête et ses méthodes: l'entretien. Paris: Nathan, 1992.

BOGDAN, R. C.; BILKLEN, S. K. Investigação qualitativa em educação: uma introdução à teoria e aos métodos. Porto: Porto Editora, 1994.

BORI, C.; DURHAM, E.R. Equidade e heterogeneidade no ensino superior brasileiro. Brasília: INEP, 2000.

BOUDON, R. A desigualdade das oportunidades: a mobilidade social nas sociedades industriais. Brasília: Editora UnB, 1981.

BOURDIEU, P. (Org.). La Misére du Monde. Paris. Seuil, 1993.

. Questions de Sociologie. Éditions de Minuit: Paris, 1980.

. Os três estados do capital cultural. In: NOGUEIRA, M. A.;

CATANI, A. (Org.). Escritos de Educação, 3a ed., Petrópolis: Vozes, 2001.

.; CHAMPAGNE, P. Les exclus de l'interieur?. In : BOURDIEU, P.

(Org.). La Misére du Monde. Paris: Seuil, 1993.

CASTEL, R. La discrimination négative: Citoyens ou indigènes? Paris: Seuil, 2007.

. De l'indigence à l'exclusion, la désaffiliation: précarité du travail et vulnérabilité relationnelle". In: DONZELOT, Jacques (org.). Face à l'éxclusion le modèle français. Paris: Esprit, 1991.

. As metamorfoses da questão social: uma crônica do salário. Rio de Janeiro, Petrópolis: Vozes, 1999.

CERTEAU, M. de. A Invenção do Cotidiano: 1. Artes de Fazer. Rio de Janeiro: Vozes, 2008.

CHARLOT, B. Du Rapport au Savoir : Éléments pour une Théorie. Paris, Anthropos, 1997. 
. Le Rapport au Savoir en Milieu Populaire: Une recherche dans les lycées professionnels de banlieue. Paris: Anthropos, 1999.

COULON, A. Le métier d'étudiant. L'entrée dans la vie universitaire. Paris: Anthropos/Econômica, 2005.

DUBET, F. As desigualdades multiplicadas. Revista Brasileira de Educação, São Paulo, n. 17, maio/ago. 2001

. A formação dos indivíduos: a desinstitucionalização.

Contemporaneidade e Educação, n. 3, mar. 1998

DURU-BELLAT, M. Les inégalités sociales à l'école: gênese et mythes. 2. ed. Paris: Presses Universitaires de France, 2003.

ELIAS, N; SCOTSON, J.L. Os estabelecidos e os outsiders: sociologia das relações de poder a partir de uma pequena comunidade Rio de Janeiro: Jorge Zahar Ed., 2000.

ESTIVILL, J. (2003), Panorama da luta contra a exclusão social - Conceitos e estratégias. Genebra: Bureau International du Travail, 2003.

INSTITUTO BRASILEIRO DE GEOGRAFIA ESTATÍSTICA. Síntese dos indicadores sociais 2007. Disponível em: <http://www.ecodebate.com. br/2008/09/25/ibge-sintese-dos-indicadores-sociais-2007-uma-analisedas-condicoes-de-vida-da-populacao-brasileira/> . Acesso em: 27 fev. 2010.

. Síntese dos indicadores sociais 2009. Disponível em: < www.ibge.gov. br>. Acesso em: 27 fev. 2010.

INSTITUTO NACIONAL DE ESTUDOS E PESQUISAS EDUCACIONAIS ANÍSIO TEXEIRA. Censo da educação superior 2008. Brasília, 2009. Resumo Técnico. Disponível em: <http://www.inep.gov.br/ download/censo/2008/resumo_tecnico_2008_15_12_09.pdf $>$. Acesso em: 08 mar. 2010.

. Censo escolar 2005. Disponível em: <http://www.publicacoes. inep.gov.br/detalhes.asp?pub=4070\# >. Acesso em: 4 mar. 2010.

KOWARICK, L. Viver em risco: sobre a vulnerabilidade no Brasil urbano. Novos Estudos, 63, jul, 2002.

NOGUEIRA, M. A.; ROMANELLI, G.; ZAGO, N. (Org.). Família e escola: trajetórias de escolarização em camadas médias e populares. 2. ed. Petrópolis: Vozes, 2003. 
NOVAES, R.; VANUCCHI (Org.). Juventude e sociedade: trabalho, educação, cultura e participação. São Paulo: Fundação Perseu Abramo, 2004.

PAIS, J. M. A construção sociológica da juventude: alguns contributos. Análise Social, v. 25, n. 105-106, p.139-165, 1990.

PNAD. Pesquisa Nacional por Amostra de Domicílios, 2008.

Disponível em: < http://www.ibge.gov.br/home/estatistica/populacao/ trabalhoerendimento/pnad2008/ Acesso em: 06 mar. 2010.

SCHWARTZ, Y. Travail et usage de soi. In: BERTRAND, M. et al. Je, Sur l'Individualité. Paris: Messidor. 1987.

SILVA, J. S. Por que uns e não outros? Caminhada de jovens pobres para a universidade. Rio de Janeiro: Sete Letras, 2003.

SPOSITO, M. P. Algumas reflexões e muitas indagações sobre as relações entre juventude escola no Brasil. In: ABRAMO, H.; BRANCO, P.P.M. (Org.). Retratos da juventude brasileira: análises de uma pesquisa nacional. São Paulo: Instituto Cidadania; Fundação Perseu Abramo, 2005.

TERRAIL, Jean-Pierre. Destins ouvriers: la fin d'une classe? Paris: Presses Universitaires de France, 1990.

UNIVERSIDADE FEDERAL DE SERGIPE. Coordenação de concurso vestibular (CCV), 2009. Disponível em: <http://200.133.41.195/ccv/ concursos/pss2009/estatisticas.html >. Acesso em: 06 mar. 2010.

FUNDO DAS NAÇÕES UNIDAS PARA A INFÂNCIA. O direito de Aprender: Potencializar avanços e reduzir desigualdades. Brasília, DF: UNICEF, 2009.

WILLIS, P. Aprendendo a ser trabalhador: escola, resistência e reprodução social. Porto Alegre: Artes Médicas, 1991.

ZAGO, N. Do acesso à permanencia no ensino superior : percurso de estudantes universitários de camadas populares. Revista Brasileira de Educação. V.11, no 32, maio/ago. 2006. 


\title{
ESTUDANTES DE ORIGEM POPULAR \\ E AFILIAÇÃO INSTITUCIONAL
}

\author{
AVA DA SILVA CARVALHO CARNEIRO \\ SONNIA MARIA ROCHA SAMPAIO
}

\section{INTRODUÇÃO}

A entrada em uma universidade impõe ao jovem uma mudança radical em sua rotina. $\mathrm{O}$ cotidiano das escolas de ensino médio diverge marcadamente do cotidiano de um curso universitário. Além das mudanças no contexto educacional, o estudante ainda precisa lidar com as transições que são típicas da juventude. Para Coulon (2008), tornar-se um estudante universitário é aprender um ofício, mesmo que temporário, para não fracassar no percurso acadêmico. Usando a linguagem etnometodológica, ser estudante universitário, é tornar-se membro, afiliarse institucionalmente e intelectualmente à vida universitária.

As exigências de uma graduação são partilhadas por todos os estudantes, no entanto, é preciso levar em conta que, para a maioria dos jovens pobres, esse sempre foi um universo praticamente impenetrável. 
Essa questão é essencial para compreender a rotina de estudantes de origem popular, em um momento em que a universidade é forçada a se democratizar pela pressão histórica dos movimentos populares. $\mathrm{O}$ objetivo principal deste capítulo é investigar aspectos da formação do estudante universitário de origem popular, mapeando os elementos relacionados à sua permanência na universidade a partir do modo como eles se afiliam às rotinas acadêmicas. Mais especificamente, volta-se para a identificação das estratégias utilizadas pelos estudantes para compreenderem a rotina institucional da universidade.

A entrada significativa de jovens de origem popular nas universidades brasileiras, principalmente em cursos de alto prestígio social, é um fato recente. Segundo Piotto (2007, p. 3), em uma pesquisa realizada durante o processo de implantação das políticas de ações afirmativas nas universidades brasileiras, "[...] dada a elitização de alguns cursos, tanto nas instituições públicas quanto nas particulares, a presença de alunos das camadas populares neles constitui exceção [...]”.

O sistema de cotas gera um debate contundente dentro e fora do ambiente acadêmico, ao possibilitar o acesso desse segmento de jovens, nas principais universidades públicas do país, a cursos tradicionalmente destinados às elites. Quase todos têm uma opinião sobre a entrada desses estudantes pobres no ensino superior. De acordo com Netto e Sá (2004), duas posições distintas são tomadas em relação às políticas de ações afirmativas, sejam elas direcionadas ou não para a população negra: as pessoas revelam atitudes a favor ou contra as cotas. Dificilmente alguém demonstra imparcialidade diante do tema. No entanto, a permanência desses estudantes e as políticas de assistência voltadas para garanti-la, habitualmente não fazem parte deste acirrado debate.

Diante de um tema ainda recente e dos poucos estudos sobre os caminhos percorridos por esses jovens nas universidades, surge minha inquietação frente à possibilidade de contribuir para o avanço desse debate, interessada em compreender como a permanência desses estudantes se dá e como eles próprios a vivenciam e significam. 
Este artigo faz parte de uma investigação sobre o cotidiano dos estudantes que tiveram acesso a cursos de alto prestígio social da Universidade Federal da Bahia, através das políticas de ações afirmativas, e propõe se aproximar dos meandros de sua permanência na universidade, no sentido de compreender as contingências a que estes estudantes estão sujeitos e de que forma eles percorrem seus itinerários, driblando adversidades ou, eventualmente, sucumbindo a elas. Dessa forma, torna-se possível compreender as diferentes maneiras que esses estudantes se utilizam para vivenciar seu cotidiano na universidade a partir de suas próprias percepções e entendimentos. O referencial teórico adotado é a Etnometodologia, vertente sociológica definida como “[...] a pesquisa empírica dos métodos que os indivíduos utilizam para dar sentido e ao mesmo tempo realizar as suas ações de todos os dias: comunicar-se, tomar decisões, raciocinar”. (COULON, 1995a, p. 30) A Etnometodologia propõe-se a investigar os etnométodos desenvolvidos pelos sujeitos, ou seja, as ações engendradas pelas pessoas em suas ações cotidianas.

\section{OS ESTUDANTES APROXIMAM-SE DA UNIVERSIDADE}

Nesta investigação, tomou-se como universo a UFBA, constituindo-se, como amostra desse estudo, os estudantes de origem popular, mais especificamente os jovens que ingressaram na universidade pelo sistema de cotas. Esta seleção foi necessária, a fim de investigar as dificuldades e as conquistas desses estudantes durante sua permanência na universidade, relacionadas ao processo de afiliação institucional, ou seja, à compreensão da rotina institucional da universidade.

Todos os estudantes pertenciam a cursos definidos como sendo de maior prestígio na Universidade Federal da Bahia. Para estabelecer quais seriam esses cursos de alto prestígio social, utilizei como referência o trabalho realizado por Queiroz (2004). Esta autora, em um artigo sobre a presença/ausência dos negros nas universidades brasileiras, discute o prestígio de alguns cursos de graduação, a partir de uma 
pesquisa, realizada na Região Metropolitana de Salvador, sobre o valor das profissões no mercado de trabalho. De acordo com Queiroz, esta pesquisa tomou como referência o elenco de cursos oferecidos pela UFBA e que resultaram em uma escala de prestígio de cinco posições - Alto, Médio alto, Médio, Médio baixo e Baixo. Essa mesma escala de prestígio respaldou, posteriormente, um estudo sobre as desigualdades raciais na UFBA. Dentre os cursos de alto prestígio social estavam: Medicina, Direito, Odontologia, Administração, Processamento de Dados, Engenharia Elétrica, Psicologia, Engenharia Civil, Engenharia Mecânica, Arquitetura e Engenharia Química. Resolvi investigar apenas trajetórias de estudantes de Medicina, Direito, Odontologia e uma das Engenharias supracitadas. Selecionei esses cursos por conta da sua tradição social e porque eles compartilham um mesmo aspecto: todos os profissionais dessas áreas são imediatamente tratados como doutores, independente de apresentarem essa titulação acadêmica. Foi realizada uma entrevista com cada estudante, além de observações participantes de atividades por eles realizadas e vinculadas à sua vida universitária.

O estudante de Direito é um residente universitário, chegou a Salvador um ano antes do vestibular para fazer cursinho e vivia em uma residência da sua própria cidade. A estudante de Medicina também morava no interior, em uma comunidade remanescente de quilombos, e veio a Salvador fazer cursinho, pois não havia sido aprovada na sua primeira tentativa de acesso ao curso. Ela mora em Salvador, na casa de um casal onde sua tia trabalhou durante alguns anos, em um bairro nobre da cidade. $\mathrm{O}$ terceiro estudante cursa Odontologia. Ele vive em uma das residências universitárias e antes morava em uma cidade do interior próxima a Salvador. Diferente dos outros entrevistados, passou no vestibular assim que concluiu o ensino médio. Ele fez cursinho paralelamente ao $3^{\circ}$ ano, o que facilitou seu acesso à universidade. Assim que chegou do interior, tentou uma vaga para residência, mas não conseguiu, por isso morou um tempo na casa de seu padrinho, com uns primos, em um bairro popular, distante da universidade. Quase um ano depois, conseguiu a vaga pleiteada na residência, o que facilitou 
bastante sua permanência. $O$ último sujeito entrevistado, o estudante de Engenharia, sempre morou em Salvador e estudava em um colégio público referência, situado em um bairro nobre.

Não houve aplicação de questionários para identificar aspectos que pudessem revelar a origem popular desses estudantes ou que fossem utilizados como critério para sua participação. Defendo que, em alguma medida, as histórias de vida desses jovens revelam suas origens e apenas aproximando-me deles e conhecendo um pouco mais o perfil de cada um é que poderia avaliar se eles se configuravam como sujeitos possíveis da minha investigação. Expliquei também, a todos, que era esse o termo que utilizava para designá-los no meu projeto - estudantes de origem popular - e indaguei se eles tinham alguma oposição a essa denominação; todos disseram que não, afirmando reconhecerem-se nessa classificação. Piotto (2007, p. 28) afirma que “[...] as condições de existência das camadas populares, assim como das demais camadas sociais, não constituem uma realidade homogênea”. Essa autora desenvolveu uma pesquisa sobre estudantes de origem popular em uma universidade pública e, por conta de uma dificuldade de definição do conceito de "classe média", bem como as críticas existentes em relação a esse conceito, ela optou por utilizar o termo camadas populares, da mesma forma que havia utilizado em outra pesquisa anterior o termo camadas médias. Assim como Piotto (2007), defendo o uso do termo origem popular na minha pesquisa.

Para selecionar os entrevistados, destinei apenas uma única pergunta que estava relacionada ao nível de escolaridade dos seus pais: perguntei a eles se seus pais possuíam nível superior. Todos disseram que não; apenas a estudante de Medicina afirmou que sua mãe cursava atualmente uma graduação, em uma instituição privada de ensino superior, na região onde morava, tendo entrado na faculdade depois dela. Essa pergunta era importante para compreender o quanto esses estudantes estavam familiarizados com a noção de universidade, quais prenoções eles possuíam acerca desse universo e de que forma seus processos de afiliação seriam influenciados por essas prenoções. De 
acordo com Coulon (2008), o processo de afiliação é uma condição para ingressar em novas modalidades da vida intelectual, por isto essa noção torna-se fundamental dentro da discussão sobre permanência de estudantes de origem popular na educação superior.

\section{ALGUMAS NOTAS SOBRE O CONCEITO DE AFILIAÇÃO}

Na obra Etnometodologia e educação, Coulon (1995b) já apresenta algumas noções sobre o conceito de afiliação, que nesta edição foi traduzida como filiação. $\mathrm{O}$ interesse do autor por este conceito parte de uma pesquisa desenvolvida por ele sobre a entrada dos estudantes na vida universitária. Coulon (1995b) destaca referências centrais para a elaboração desse conceito, como a noção de habitus de Bourdieu e a noção de membro proposta por Harold Garfinkel. As ideias defendidas por esses autores fundamentam o conceito, desenvolvido por Alain Coulon, que deu origem ao livro $A$ condição de estudante: a entrada na vida universitária, de 1997, traduzido para o português em 2008.

Ainda em Etnometodologia e educação, Coulon (1995a) mostra uma clara associação entre o conceito de afiliação e a noção de membro. Para o autor, o estudante afiliado é aquele cuja competência torna-se uma rotina, ele possui todas as características de um membro e desenvolve as tarefas sem estranhamento. A afiliação do sujeito implica no fato dele deixar de pensar no que está fazendo e simplesmente conseguir desenvolver as ações cotidianas de uma forma "automática". No livro A condição de estudante, o autor amplia sua definição e afirma que a afiliação é o método pelo qual as pessoas adquirem um novo status social. Podemos pensar na noção de afiliação como um processo contínuo, que se repete ao longo da vida do sujeito, cada vez que ele precisa se tornar membro de um novo grupo e assimilar novas funções, desenvolver novas tarefas.

Da mesma forma que o sujeito se mobiliza para novas aprendizagens, ele também carrega, em parte, um antigo habitus, referência à noção desenvolvida por Pierre Bourdieu, que defende que o sujeito tende 
a reproduzir um sistema de condições objetivas das quais é produto. Coulon (1995b, p. 156) ressalta, no entanto, que:

[...] a sociologia dos habitus de P. Bourdieu dá conta das condições estruturais que pesam sobre essa passagem, mas, em compensação, não chega a mostrar como ela se efetua concretamente, nem quais formas assume a objetivação prática dos atores que efetuam tal passagem.

O que interessa à compreensão do processo de afiliação é o modo como os atores desenvolvem determinadas tarefas, ao se depararem com um novo contexto, como elaboram as ações no grupo a fim de conseguirem se tornar membros.

Coulon (1995a, 1995b) dedica-se exclusivamente ao processo de afiliação educacional, mais precisamente ao processo de afiliação à vida universitária, que define a transição do ensino médio para a educação superior. Para ele, a entrada do estudante na educação superior é marcada por três tempos: o tempo de estranhamento, no qual o estudante se depara com um universo desconhecido, bem diferente da instituição escolar da qual fazia parte; depois, ele atravessa o tempo da aprendizagem, uma etapa marcada por adaptações e acomodações progressivas e, por fim, o tempo da afiliação, onde o estudante já compreende as normas e regras institucionais e adquire o status de membro: aprendeu o ofício de estudante universitário.

Uma conclusão satisfatória da graduação requer este processo de afiliação, que se subdivide em dois âmbitos: o intelectual e o institucional. No âmbito intelectual, o estudante deve atender ao que Coulon (2008) define como exigências acadêmicas em termos de conteúdos intelectuais, métodos de exposição do saber e dos conhecimentos. Já a afiliação institucional refere-se à aprendizagem dos códigos do ensino superior, à utilização da instituição em termos de assimilação das práticas e rotinas, uma afiliação às características administrativas. $\mathrm{O}$ estudante afiliado institucionalmente é aquele que compreende e segue as normas da instituição, seu funcionamento e seus prazos. Para 
Malinowski (2008), a noção de afiliação é extremamente frutífera, por levar em consideração tanto as dimensões subjetivas, com as dimensões simbólicas da relação que os estudantes desenvolvem com a vida universitária. Este autor salienta também que a definição de afiliação sustentada por Coulon (2008) deve abranger, não apenas o conhecimento explícito das regras, mas a reinterpretação e apropriação delas como um novo atributo de competência desenvolvido pelo estudante.

Nas entrevistas, busquei compreender como os estudantes lidavam com as situações vinculadas à permanência na universidade, considerando as condições adversas às quais eles estiveram rotineiramente submetidos. Era necessário saber como eles lidavam com as normas e regras da universidade, enfim, com o funcionamento característico do ensino superior. O conceito definido por Coulon (1995a, 2008) aponta para duas questões centrais na permanência do estudante em relação à universidade: a compreensão da instituição universitária em si, com seus modos próprios de funcionamento, e a compreensão do conteúdo intelectual desenvolvido nas salas de aula. Embora haja outras dinâmicas envolvidas na questão da permanência do estudante universitário, todas elas irão desembocar no processo de afiliação, seja ele intelectual ou institucional. Essas outras dinâmicas são principalmente de natureza relacional, sejam relações com a família ou com outros estudantes, e formam os "arquipélagos de certeza" (MORIN, 2000) que asseguram ao jovem parte da sua inserção institucional e intelectual na universidade. Para Morin (2000), dentre os "arquipélagos de certeza", há um oceano de incertezas, situações imprevisíveis a serem combatidas com estratégias. Essas estratégias, por sua vez, são o interesse central desta investigação.

Acredito também que um estudante pode concluir um curso de graduação sem necessariamente afiliar-se a esses elementos, mas inevitavelmente, seu processo de conclusão do curso não acontecerá de forma satisfatória. Embora este artigo se detenha sobre aspectos relacionados à afiliação institucional, durante as entrevistas, os estudantes apontaram outras questões que possivelmente estão associadas à 
permanência na universidade, como as relações com os familiares e a trajetória escolar/educacional. Foi preciso considerar cada fala desenvolvida por eles, suas referências e desta forma prosseguir com a análise para apontar novos elementos e direcionamentos.

\section{A ADAPTAÇÃO AO COTIDIANO UNIVERSITÁRIO}

Primeiro é preciso encontrar o prédio em que haverá aula. Depois, localizar em um mural de aviso, repleto de códigos, aquele correspondente à disciplina que se está procurando. Conferir no seu comprovante de matrícula se o código identificado no quadro é realmente o código da disciplina que procura. Se for, terá que localizar, nesse mesmo mural, a sala em que a disciplina será ministrada. Ah, também tem que ter cuidado, pois algumas disciplinas têm suas turmas divididas em aulas teóricas e práticas, sendo necessário verificar a qual turma pertence. Localizou o código, a disciplina, a turma, a sala [...]. Mas, no mural não há um mapa, então é preciso correr para achar a sala, esperando que elas sigam uma sequência numérica lógica. No caminho, alguns colegas ainda têm dúvidas, mas seguem juntos, assim é mais fácil. Chegam atrasados à aula, certificam-se de que estão na sala correta e se sentam rapidamente; logo já terão novas questões para se preocupar.

Ora, esta é uma sequência de ações típicas de um estudante em seu primeiro dia de aula; infelizmente, na maioria das vezes, ele não prevê esta sequência de acontecimentos e perde bastante tempo para realizar tarefas que, semestres depois, tornar-se-ão bastante simples. Este estranhamento em relação às tarefas relativas à vida universitária não se restringe ao primeiro dia ou à primeira semana de aula; afiliar-se à rotina acadêmica requer uma aprendizagem progressiva, que envolve diversas atividades vinculadas a esse ambiente.

Ao ver um quadro repleto de códigos, diz o estudante de Engenharia: Rapaz... eu não tô entendendo nada, o que é isso aí? [...] como é isso aqui? Eu não sei traduzir isso aqui não [...]. Logo obtém a resposta de um colega: [...] isso aqui é o código, você tem que olhar o código dessa matéria 
[...]. Com as indicações, ele efetua a leitura dos códigos e desvenda a utilidade atribuída a este sistema referente às disciplinas, avançando desta maneira na compreensão de um aspecto relevante de sua rotina acadêmica. Para Coulon (2008, p. 81), "Entrar na universidade é explorar e querer voluntariamente mergulhar nos códigos que definem esta organização, códigos estes, frequentemente, opacos ou ilegíveis”. O estudante de Direito também revela suas dificuldades em desvendar estes códigos, ainda no primeiro semestre, quando participava de uma semana do calouro, organizada por estudantes veteranos na sua Faculdade:

[...] eles fizeram assim [...] um momento com os estudantes, explicando como era o regimento da faculdade, como era pra fazer a matrícula, como era pra qualquer coisa, pra trancar a disciplina, trancar semestre [...] Hoje eu não lembro de nada que eles falaram, mesmo porque era uma língua que a gente não dialogava. (Estudante de Direito)

A vida universitária é composta por um conjunto de regras e o estudante é convocado a apreender parte delas, ainda no primeiro semestre, a fim de garantir sua permanência nesse ambiente. De acordo com a compreensão etnometodológica, a utilização de uma regra não está contida no seu enunciado. A utilização que as pessoas fazem deste enunciado e as ações que são engendradas é que definem uma regra propriamente dita. Este princípio remete à noção de indexicalidade, afinal, toda a linguagem é significada a partir do contexto; sendo assim, é preciso fazer parte do contexto para apropriar-se de uma determinada linguagem. Na semana do calouro, os estudantes recém-ingressos no curso de Direito não compartilhavam a mesma linguagem dos veteranos, eles ainda não eram considerados membros, não tinham adquirido o status de estudante universitário. Desta forma, o estudante de Direito só poderia apreender as regras que foram listadas, quando desenvolvesse etnométodos que garantissem a sua inserção neste universo. Para Coulon (1995b), as pessoas que se mantêm presas às regras tendem fatalmente a fracassar na tentativa de afiliação a um novo contexto. 
O estudante de Direito também relata a grande quantidade de informações das quais deve se lembrar, necessárias que são para a execução das tarefas no cotidiano universitário. Parte delas refere-se a números e senhas que dão acesso aos serviços utilizados pelos estudantes. É preciso lembrar-se do número da matrícula e também da senha para realizar a matrícula na internet, há também uma senha para a biblioteca, além de cadastros na assistência estudantil e para acesso à internet no Centro de Processamento de Dados. Por não conseguir memorizar todos estes dados, registrava as informações mais importantes: $E \mathrm{eu}$ lembro que eu anotava né, tudo anotadinho, CPD [Centro de processamento de dados] do lado, escondido na agenda pra ninguém achar porque senão eu me perdia naquele tanto de senha.

Cada estudante encontrará modos específicos de afiliar-se institucionalmente, segundo a etnometodologia, cada um apresentará diferentes etnométodos. O estudante de Engenharia, por exemplo, revela que suas dúvidas, logo no primeiro dia de aula, quando teve acesso ao mural com os códigos das disciplinas, foram solucionadas por outro estudante. $\mathrm{O}$ conhecimento demonstrado pelo colega que o ajudou faz com que o estudante acredite que ele já fazia parte do ambiente acadêmico ou que, ao menos, conhecia outras pessoas que já eram "membros" da universidade: Acho que ele já tinha conhecimento com gente que já tava lá dentro e conhecia e explicou, porque eu não sabia.

Uma das formas de acessar as informações que definem o cotidiano da educação superior é através do estabelecimento de contatos na universidade, se possível, ainda antes de chegar até ela, pois essa estratégia facilita a chegada do estudante na educação superior, do mesmo modo que amplia a compreensão acerca do funcionamento da instituição.

Mas, se levarmos em conta que os participantes desta pesquisa são muitas vezes os primeiros a acessar o ensino superior em suas respectivas famílias ou rede social, como ter acesso a esses conteúdos previamente? Esses estudantes rompem com uma tradição ordinária em seu meio, que é a reprodução, há muitas gerações, de uma escolaridade de curta duração. Esse fato conduz, inevitavelmente, a um desconhe- 
cimento da rotina universitária, que só pode ser superado pela própria vivência acadêmica, principalmente a vivência com outros estudantes provenientes da mesma origem.

Cada conquista marca uma etapa do processo de afiliação do estudante e reafirma sua permanência no ensino superior. Ainda na primeira semana de aula, o estudante de Odontologia não conseguia localizar as salas onde seriam ministradas as disciplinas:

Eu achava que era aula teórica, era aula prática e eu ficava meio perdido ali naquele ICS [Instituto de Ciências e Saúde]. Eu ia pra aula de Microbiologia, entrava e era outra turma, não era a turma de Odonto, era engraçado naquela época. (Estudante de Odontologia)

Esse estudante relata que, antes do início das aulas, visitou os prédios que frequentaria ao longo do semestre. Mesmo já conhecendo esses prédios, foi grande sua dificuldade em localizar as salas onde sua turma se encontrava; incapaz de distinguir entre turmas teóricas e práticas, perdeu algumas aulas durante a primeira semana. $\mathrm{O}$ prolongamento desta dificuldade acarretaria possivelmente a perda de novas aulas, desequilibrando a conclusão do semestre e constituindo um risco à sua permanência. Aos poucos, conversando com outros estudantes, ela iria descobrir o local e horário das suas aulas; foi preciso situar-se no espaço e no tempo da universidade.

Algumas destas situações enfrentadas pelos jovens com bastante dificuldade no início de sua vida universitária são referenciadas por eles com menos pesar depois de algum tempo. O estudante de Odontologia, por exemplo, afirma que era "engraçado" percorrer a universidade à procura da sua turma na primeira semana de aula. O estudante de Direito, em um registro similar, afirma que era "interessante" quando ele chegava à biblioteca e precisava de um livro, mas não sabia fazer a reserva, depois corrige: [...] eu acho interessante hoje, mas na época era uma dor de cabeça [...].

O processo de afiliação promove uma descoberta de interpretações que estavam invisíveis ao estudante; afiliados, eles parecem não re- 
conhecer mais sua cegueira inicial, ou, ao menos, não se incomodam da mesma forma com os primeiros tropeços. Em alguns momentos, os estudantes parecem não saber explicar como aprenderam determinados mecanismos da educação superior e, só ao longo da entrevista, desenvolvem o raciocínio subjacente às suas ações. O estudante de Direito, por exemplo, revela como agiu para superar sua dificuldade relacionada à reserva de livros:

Porque eu lembro que a página [refere-se à página virtual da biblioteca] ela não é muito clara, de reserva, você vai lá, acessa 'Usuário', e depois tem lá: 'Reserva'. Aí tem dois campos em branco, eu não sabia o que preenchia, até que conversando com outras pessoas aí eu comecei a ver como era reservar, aprendi a reservar [...] Aí a gente vai descobrindo as coisas né? Desse jeito assim, com conversa, muito a partir da conversa mesmo com as pessoas.

Todos os estudantes entrevistados aproximam-se de outros colegas, preferencialmente aqueles que já estão há mais tempo na educação superior, e lançam sua dúvidas acerca dos códigos universitários. Este foi o etnométodo principal identificado para a afiliação ao sistema de regras da universidade. Coulon (2008), em sua pesquisa sobre a afiliação de estudantes universitários franceses ao ensino superior, também conclui que as informações reais e práticas são transmitidas comumente pelos colegas mais velhos; os manuais e informações oficiais não figuram como indicadores principais na passagem de conhecimentos, provavelmente pela pouca efetividade.

Alguns estudantes de origem popular, eventualmente encontram outros sistemas de suporte que auxiliam seu processo de adaptação. A estudante de Medicina, por exemplo, descreve o apoio que recebeu do casal com quem morava durante os seus primeiros dias de aula:

Pra matrícula mesmo eles foram comigo, porque assim, eu não sabia andar de ônibus, né? Então todos os lugares que eu ia, eu ia com eles. Então eles iam, me levavam lá de carro, me buscavam, então era aquela coisa. Foi assim até umas duas semanas e era muito difícil porque às vezes eu ligava 
pra ele né, pra poder vir me buscar que eu tinha que ir pra outro lugar, mas ele tava ocupado [...].

Receber o apoio desse casal permitiu que a estudante desenvolvesse suas atividades de forma bem-sucedida; foi possível realizar a matrícula, deslocar-se de um campus para o outro, sem atrasos ou dificuldades; no entanto, a estudante não construía o seu processo de afiliação universitária. Ela não conseguia ainda compreender as regras e códigos da educação superior, pois não conduzia suas próprias ações. As ações eram desenvolvidas pelo casal e ela percebeu que essa situação não deveria perdurar, pois eles desenvolviam outras atividades e não poderiam auxiliá-la por muito tempo nesta etapa. Para apropriar-se do funcionamento desse sistema precisou, então, desenvolver novos etnométodos: Quando eu encontrava alguém eu perguntava que ônibus eu vou pegar, isso pra colegas [...] Aí aprendi primeiro ir pra Ondina, foi o primeiro trajeto de ônibus [...] aos poucos fui me acostumando e hoje consigo andar tranquilamente [...].

Quando as ações passam a ser engendradas pela própria estudante, e não mais por seus cuidadores, ela apreende o funcionamento da rotina estudantil; já não precisa mais recorrer a eles para deslocar-se entre os campi, por exemplo. Ela salienta, no entanto, o cuidado que possui ao receber algumas informações: não considera as indicações de qualquer pessoa e prioriza apenas aquilo que é dito por seus colegas mais próximos. Para Coulon (2008), os estudantes comumente têm a sensação de que podem estar sendo enganados, por isso costumam verificar a veracidade das informações que lhes são fornecidas. Isso ocorre, possivelmente, por conta das informações contraditórias que circulam neste ambiente; mesmo funcionários da universidade costumam não apresentar um consenso em relação a determinados procedimentos, $o$ que provoca a desconfiança do estudante que precisa assegurar a informação antes de executar uma ação. 


\section{CONCLUSÃO}

A consolidação do processo de afiliação institucional permite ao estudante desenvolver diferentes novas ações no espaço universitário que resultam, por sua vez, em outras importantes ações relativas à sua permanência. É preciso, em um primeiro momento, situar-se, temporal e espacialmente, para então apropriar-se das regras do ambiente. Apropriando-se das regras, os estudantes desenvolvem novas formas de fruição, otimizando o cotidiano e aproximando-se de uma vivência universitária mais consistente.

Acompanhar estudantes mais velhos para compreender o funcionamento do cotidiano acadêmico é um dos etnométodos mais frequentes utilizados pelos estudantes recém-ingressos. Inicialmente, eles costumam dirigir-se a setores da universidade para esclarecerem suas dúvidas, mas, quando o fazem, costumam receber informações contraditórias que não reforçam a busca desse tipo de serviço. Têm igualmente dificuldades em compreender muitas das informações que são disponibilizadas pela instituição, no momento em que entram na educação superior; a forma como as informações estão descritas costuma ser incompatível com a linguagem do estudante que ainda não detém os códigos da universidade. Deste modo, é possível discutir a produção de modos alternativos de divulgação de procedimentos úteis e necessários e buscar uma utilização maior, seja de registros duráveis, como cartilhas ou informações disponibilizadas on-line, com recursos de interatividade, para que o estudante tenha como verificar e confirmar algumas instruções ao longo do seu primeiro ano universitário.

Para os estudantes do interior, o processo de afiliação não se restringe ao ambiente acadêmico; antes de se localizarem nas suas faculdades, precisam localizar-se nos espaços urbanos. Situar-se espacialmente na cidade é pré-requisito para uma compreensão posterior dos seus respectivos campus e para o deslocamento entre as unidades e serviços 
universitários. A UFBA, diferente de outras universidades públicas, constituiu-se geograficamente de forma descentralizada, o que compromete a apreensão desse espaço e o deslocamento dos estudantes.

Todas essas questões, que se tornam risíveis aos estudantes, após certo tempo na educação superior, são, inicialmente, vivenciadas por eles com grande aflição, frente a um espaço desconhecido, com modos e regras específicos e cuja compreensão determina todo o seguimento do curso. Para o jovem de origem popular, essa compreensão do modo de ser da universidade e do modo de ser universitário pode ser retardada por um desconhecimento, tanto do estudante, quanto da sua família, no que toca às rotinas acadêmicas. Os alunos oriundos de escolas particulares geralmente chegam à universidade com um maior entendimento das regras que guiam a educação superior.

Para afiliarem-se, os estudantes de origem popular precisam constantemente recorrer a outros alunos, ou eventualmente a funcionários e professores. A entrada na educação superior convoca esse jovem a fazer parte de novos grupos e a estabelecer novas interações. Sendo assim, é possível presumir que sua permanência dependerá da natureza das relações que eles estabelecem no interior da universidade.

A afiliação institucional é apenas um dos pilares que constituem a vida universitária e que possibilitam a permanência no ensino superior. Este artigo também aponta outras dimensões essenciais para a formação do estudante, como a afiliação intelectual e as interações estabelecidas no ambiente acadêmico. Para tornar-se estudante universitário é preciso superar as adversidades e filiar-se a um novo espaço, apreendendo seus modos e seus usos. 


\section{REFERENNCIAS}

COULON, Alain. Etnometodologia. Petrópolis: Vozes, 1995a. . Etnometodologia e educação. Petrópolis: Vozes, 1995b. . A condição de Estudante: a entrada na vida universitária. Salvador: EDUFBA, 2008.

MALINOWSKI, Nicolas. Diferenciación de los tiempos estudiantiles e impacto sobre el proceso de afiliación en México. Revista Latinoamericana de Ciencias Sociales, Niñez y Juventud, Manizales, v. 6, n. 2, p. 801- 819, 2008.

MORIN, Edgar. Os Sete Saberes necessários à Educação do Futuro. São Paulo: Cortez; Brasília: UNESCO, 2000.

NETTO, Tânia Maria de Castro Carvalho; SÁ, Márcia Souto Maior Mourão. Ações afirmativas na universidade pública brasileira: (uma) resposta inclusiva às exclusões. In: CONGRESSO LUSO-AFRO-BRASILEIRO DE CIÊNCIAS SOCIAIS, 8., 2004, Coimbra, Anais... Coimbra: Centro de Estudos Sociais, 2004, p. 1-10.

PIOTTO, Débora Cristina. As exceções e suas regras: estudantes das camadas populares em uma universidade pública. 2007.361 f. Tese (Doutorado em Psicologia Escolar e do Desenvolvimento Humano) - Instituto de Psicologia, Universidade de São Paulo, São Paulo, SP, 2007. Orientadora: Prof. ${ }^{a}$ Dr. ${ }^{a}$ Maria Clotilde Rossetti-Ferreira.

QUEIROZ, Delcele Mascarenhas. O negro e a universidade brasileira. Asociación de Historia Actual, n. 3, p. 73-82, 2004. 


\section{QUESTÕES CONTEMPORÂNEAS \\ NO COTIDIANO DA UNIVERSIDADE}

algumas implicações temporais

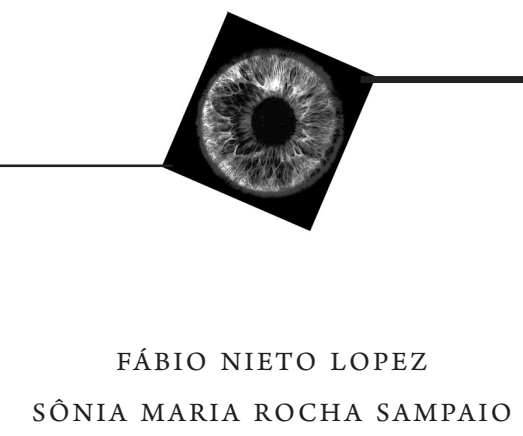

O debate sobre a universidade, com frequência, passa ao largo das questões que a contemporaneidade nos coloca, como as novas e, por vezes, impositivas maneiras de lidarmos com o cotidiano e com as instituições. De fato, se pensar a universidade ainda é tarefa para poucos interessados, incluir nessa agenda as implicações das atuais transformações macroeconômicas, tecnológicas, culturais e políticas, parece tornar mais árida a discussão e restringir muito os interlocutores.

Por outro lado, é possível perceber as consequências profundas de aspectos como o tempo e o espaço em modalidades fundamentais do funcionamento tanto das instituições quanto do nosso cotidiano. Além disso, há constantes referências às transformações tempo-espaciais nas teorias da contemporaneidade, que afetam, decisivamente, a universidade e as relações sociais no seu interior. 
Defende-se, nesse texto, a necessidade de se considerar questões da contemporaneidade para aprofundar discussões relativas à entrada dos estudantes na vida universitária, assim como todo o seu processo de afiliação à nova instituição onde ingressam. Como ponto fundamental de estudo, escolhe-se, mais especificamente, as questões do tempo, compreendidas, atualmente, em intensa transformação e com implicações diretas na vida dos estudantes, assim como na economia global e, portanto, na universidade como um todo.

Nesse momento, tratar somente do tempo torna-se uma restrição circunstancial desse capítulo, por não ser possível abarcar também aprofundamentos sobre as questões do espaço, por mais que estas sejam entrelaçadas com as questões do tempo e, exatamente por esse motivo, mais de uma vez sejam tocadas aqui.

\section{A UNIVERSIDADE E A CONTEMPORANEIDADE}

As últimas décadas trouxeram implicações profundas, do ponto de vista macroeconômico e social, afetando diversas esferas e instituições. A universidade não escapou a essas tensões e mudanças contemporâneas, que envolvem a sociedade como um todo, e, como seria de se esperar, atravessaram seu muros afetando também sua estrutura e relações com sua população.

Santos (2005), no intuito de pensar a universidade, retoma os últimos acontecimentos, desde meados da década de 90 até o ano de 2005, analisando os impactos das questões macroeconômicas nos Estados Nacionais, e nas relações destes com as universidades públicas e particulares. Podemos observar, no pensamento do autor, o desenrolar de questões contemporâneas postas à universidade que geraram crise em sua condição até então intocada e lustrosa ${ }^{1}$.

1 Boaventura (2005) destaca três crises específicas da universidade: Crise de Hegemonia - A partir da incapacidade da universidade dar conta das novas demandas, o Estado e o mercado recorrem a alternativas fora da universidade; Crise de Legitimidade - Ocorre quando a universidade deixa de ser uma instituição consensual, e passa a ser questionada tanto pelas restrições ao acesso de seus saberes quanto pela distância e descompro- 
No interior desse marcador temporal, o autor observa a consolidação mundial do modelo neoliberal de capitalismo, que acaba por pressionar os Estados Nacionais a reduzirem, drasticamente, suas prioridades sociais e seus compromissos políticos com a educação, a saúde e a previdência. As universidades públicas, por sua vez, passaram por um processo de descapitalização e, em diversos países, foram privatizadas ou tiveram que competir com instituições privadas nacionais e, depois, transnacionais, em disputa pelo novo serviço à disposição do mercado - o serviço universitário. Assim, em poucas décadas, a universidade e o ensino perderam a condição de bem público, para tornaram-se apenas um bem, e, como tal, passível de produção, distribuição e comercialização, por parte de seus produtores, e de uso e consumo por parte da sua clientela.

Ainda segundo Santos (2005), a universidade passa, então, a ser entendida na mesma lógica da globalização e a ser vista e gerida segundo as mesmas bases de uma empresa, no paradigma de maximizar rentabilidade, servindo como incubadora de novos serviços e como fornecedora de capital humano para a economia de serviços e da sociedade da informação, onde a educação assume um lugar de destaque. Grandes instituições internacionais, como a Organização Mundial do Comércio, o Fundo Monetário Internacional e o Banco Mundial, através de seus empréstimos financeiros, pressionam os países, em seus acordos comerciais, a adotarem medidas que se ajustem a um regime geral de serviços mundiais, abrindo as fronteiras dessas nações para a comercialização da educação, entendida agora como um serviço como os demais.

Assim como Santos (2005), Almeida Filho (2007) considera as questões macroeconômicas envolvidas na contemporaneidade, entendendo que esses processos interferem no cotidiano universitário. Nessas obras, tanto o primeiro quanto o segundo autor discutem propostas

misso com questões sociais; Crise Institucional - Quando se estabelece a contradição entre a autonomia universitária nas definições de suas funções e objetivos e as pressões crescentes para se submeter a critérios diferentes dos seus, como eficácia, produtividade empresarial e responsabilidade social. 
para outra universidade, desta vez mais porosa às questões sociais, mais comprometida com suas comunidades, com os destinos políticos do país, defendendo que os Estados Nacionais resgatem os compromissos sociais com suas populações, ao garantirem, entre outras coisas, acesso, permanência e qualidade na educação.

$\mathrm{Na}$ análise de Bauman (2001), o imperativo atual é o de ser leve, líquido e operar o derretimento dos sólidos que atrapalham a consolidação de uma contemporaneidade fluida, de característica cambiante, móvel, inconstante e imprevisível. Derreter os sólidos significa eliminar as obrigações e embaraços das empresas com a família, e com as questões éticas, políticas e culturais, para deixar somente o dinheiro entre seus assuntos. Para o autor, as transformações que suscitaram a "modernidade fluida" possuem impacto profundo na condição humana e, um dos principais pontos para se investigar essas novas condições, são as questões de tempo-espaço, apesar de existirem outros "marcadores" que podem ser utilizados. Bauman (2001, p. 15), no entanto, insiste que a relação cambiante entre o espaço e o tempo é a "diferença que faz a diferença”:

A modernidade começa quando o espaço e o tempo são separados da prática da vida e entre si, e assim podem ser teorizados como categorias distintas e mutuamente independentes da estratégia e da ação; quando deixam de ser, como eram ao longo dos séculos pré-modernos, aspectos entrelaçados e dificilmente distinguíveis da experiência vivida, presos num estável e aparentemente invulnerável correspondência biunívoca.

De modo semelhante, posiciona-se David Harvey (2009), ao defender a tese de que as mudanças abissais que ocorreram na política, na economia e na cultura, imprimiram novas maneiras pelas quais experimentamos o tempo e o espaço. Embora nenhum desses autores defenda a primazia das condições de tempo-espaço sobre os outros fatores envolvidos nas mudanças contemporâneas, a análise produzida por eles, sobre as implicações dessa dimensão específica, contribui, signi- 
ficativamente, para aprofundar as observações sobre seus impactos em nossas relações cotidianas.

\section{QUESTÕES ACERCA DO TEMPO}

A história do tempo começou com a modernidade BAUMAN, 2001, p. 128

Em uma conhecida passagem, Santo Agostinho (1999, p. 322) esforça-se em desvendar os enigmas do tempo, tentando compreendê-lo filosoficamente nessa obra escrita no século IV, entre 397 e 398:

Que é, pois, o tempo? Quem poderá explicá-lo clara e brevemente? Quem o poderá apreender, mesmo só com o pensamento, para depois nos traduzir por palavras o seu conceito? E que assunto mais familiar e mais batido nas nossas conversas do que o tempo? Quando dele falamos, compreendemos o que dizemos. Compreendemos também o que nos dizem quando dele nos falam. O que é, por conseguinte, o tempo? Se ninguém mo perguntar, eu sei; se o quiser explicar a quem me fizer a pergunta, já não sei. Porém, atrevo-me a declarar, sem receio de contestação, que, se nada sobreviesse, não haveria tempo futuro, e agora nada houvesse, não existiria o tempo presente.

A ansiedade e dúvida sobre a definição do tempo, como um bom problema filosófico, chegaram até nossos dias, assim como a relativa indiferença no modo como o tema é tratado. Como afirma David Harvey (2009), o tempo e o espaço, por serem categorias básicas da existência humana, deixam de ser problematizados e, raramente, recebem investigações mais criteriosas, ficando a cargo de atribuições do senso comum ou autoevidentes.

Concordando com Santo Agostinho, Norbert Elias (1998, p. 7), compreende a complexidade da tarefa de se definir o tempo, e, ao mesmo tempo, da necessidade de entendermos melhor os problemas a ele relacionados para aprendermos sobre a humanidade e suas relações: 
"Mas o tempo não se deixa ver, tocar, ouvir, saborear nem respirar como um odor".

De modo semelhante, André Comte-Sponville (2006, p. 17) compartilha com o filósofo Santo Agostinho as mesmas angústias:

O tempo parece indefinível, inapreensível, como se só existisse em sua fuga, como se só aparecesse com a condição de sempre desaparecer, e tanto mais obscuro como conceito quanto mais como experiência. É uma evidência e um mistério: ele só se revela ocultando-se; só se entrega em sua perda; só se impõe a todos no próprio movimento pelo qual de todos escapa.

Embora o constrangimento angustiante que o tempo impõe ao pensamento filosófico e as dificuldades de apreendê-lo, Comte-Sponville (2006) opera uma distinção importante entre o tempo da consciência (ou o tempo da alma, tempo subjetivo), e o tempo real (do mundo, natural, objetivo). O relógio seria um mecanismo que mensura o tempo real. Como nos diz Elias (1998), os relógios são padronizações de nossa sociedade em que processos físicos são decompostos em horas e minutos, unidades com regularidade recorrente. A partir dessa padronização, torna-se possível a comparação entre dois eventos distintos quanto à extensão dos minutos e das horas.

Ainda sem nossos relógios modernos ou outros recursos técnicos para auxiliá-lo na angústia de não se conseguir medir o tempo, Santo Agostinho (1999, p. 329) confessa: "O meu espírito ardeu em ânsias de compreender este enigma tão complicado.” Santo Agostinho (1999) relaciona inicialmente o tempo com o movimento dos corpos no espaço e na comparação entre diferentes durações, mas logo refuta a possibilidade de se conhecer a duração do tempo através desse princípio, uma vez que poderíamos utilizar o próprio tempo para medir o movimento ou a ausência dele. Assim, se um corpo manteve-se parado, poderia se afirmar que ele permaneceu parado por tanto tempo. Em uma tentativa de classificação, o autor determina três categorias: passado, presente e futuro, mas também o tempo "breve" e o tempo "longo". 
Retomando as ideias de Comte-Sponville (2006), o tempo da consciência (da alma, subjetivo, do coração) é aquele em que a duração dos eventos é pesada segundo o prazer ou a dor de nosso mundo interior, passando mais ou menos depressa, a depender desse critério subjetivo, e aqui podemos pensar na distinção feita por Santo Agostinho (1999) entre o tempo breve e o tempo longo. Esse tempo da consciência é múltiplo, heterogêneo, desigual. Como lembra Norbert Elias (1998), dois discursos seguidos um do outro, com a mesma duração real, podem ter tempos subjetivos muito diferentes.

Segundo Comte-Sponville (2006), o tempo da consciência é a sucessão do passado, presente e futuro, mas, para o tempo real, o futuro não existe porque ainda não é, e o passado não existe, uma vez que já não é. O presente, para o tempo real, é um ponto de tempo sem nenhuma extensão de duração, portanto já nem seria tempo: "O tempo é essa abolição de tudo, que parece abolir a si mesma: a fuga do tempo é o próprio tempo" (COMTE-SPONVILLE, 2006, p. 19). Desta forma, sem a alma, só haveria esse fragmento de tempo, o presente perpétuo, e, segundo o autor, se não houvesse mais do que o presente não haveria tempo. É a alma que faz existir o tempo, que liga algo que passou com o que ainda pode vir; é a alma "[...] a única capaz de fazer existir juntos, numa mesma presença de si, um antes e um depois [...]” (COMTESPONVILLE, 2006, p. 29). A esse tempo, com passado, presente e futuro, o autor chama de temporalidade.

Comte-Sponville (2006) retoma, então, as noções de tempo para Aristóteles (apud COMTE-SPONVILLE, 2006), que entende a existência do tempo em relação à mudança: quando distinguimos uma mudança, aí percebemos a passagem do tempo. Assim, não haveria passagem de tempo sem movimento ou mudança. Essa noção de Aristóteles também pode nos ajudar a pensar as questões de tempo-espaço na contemporaneidade devido à sua relação estreita com o movimento e a mudança. Ainda no âmbito filosófico, poderíamos pensar que a percepção da compressão de tempo-espaço é disparada, não somente pela crescente velocidade do giro de mercadorias e de capitais, pela flexibilização da 
economia e das relações de trabalho, mas, também, na impressionante sensação de parque de diversões que experimentamos, atualmente, submetidos que somos à sucessão veloz e incessante de mudanças, fragmentações e movimento. Na vertigem da velocidade e da flexibilização das estruturas, como destacam Bauman e David Harvey (2009), a experiência de tempo-espaço é alterada significativamente.

As noções de longe, perto, cedo e tarde, segundo Bauman (2001), quando ainda não havia sido rompida a relação íntima entre tempo e espaço, traziam as noções do quanto de esforço era necessário para se percorrer uma determinada distância. Assim, quem colocava o limite era a capacidade humana ou animal para transpor um espaço. Com a construção de veículos mais velozes que a capacidade humana e animal, essa noção se rompe e passa a ser contabilizada como uma questão técnica, uma vez que os veículos podem ser cada vez mais aperfeiçoados. O tempo passa a ser o elemento dinâmico na relação de tempo e espaço, porque pode ser mudado e manipulado com as novas técnicas, passando a ser uma ferramenta para se vencer as resistências do espaço, encurtando distâncias. Em analogia inspirada, Bauman (2001) declara essa relação estreita entre as novas questões temporais e a contemporaneidade, ao dizer que a modernidade nasceu sob as estrelas da aceleração e da conquista de terras, e essas estrelas formam uma constelação que contém toda a informação sobre seu caráter, conduta e destino.

Continuando sua análise, Bauman (2001) analisa que o tempo é fator fundamental nas novas composições, porque ele se tornou dinâmico e passa a ser utilizado como ferramenta para vencer o espaço, encurtando distâncias através do tempo acelerado que as máquinas, cada vez mais velozes, proporcionam. Por um determinado momento, na "modernidade pesada", a conquista de grandes faixas territoriais e a manutenção desses espaços a todo custo foi a tônica das relações de poder, mas, com a "modernidade leve", o modelo "quanto maior, melhor" torna-se cada vez mais desajeitado. Na "modernidade leve", com as novas tecnologias, que conseguem operar na velocidade da luz, o espaço perdeu quase completamente o seu valor, a ponto de se desmancharem 
as distinções entre o "longe" e o "perto": ambos podem ser acessados instantaneamente por quem acessa o tempo veloz. Se todas as partes do globo podem ser acessadas, visitadas e abandonadas, o espaço, em si, é desvalorizado, já que não há lugar privilegiado, nem especial.

Ainda pensando em diferentes conceitos para discutir as relações contemporâneas com o tempo e espaço, importante trazer as contribuições de Giddens (1989), principalmente de seu conceito de "convergência de tempo-espaço", segundo o qual as distâncias são estabelecidas em função do tempo necessário para mover-se entre as diferentes localizações e, não exatamente, em uma relação com a medição da quilometragem. $\mathrm{O}$ exemplo que o autor traz se refere ao tempo necessário para atravessar da Costa Leste à Costa Oeste dos Estados Unidos, cuja viagem, a pé, levaria mais de dois anos; a cavalo, oito meses; de trem, em 1910, quatro dias; e, atualmente, de avião, cinco horas e, se for a jato, apenas duas horas. Observa-se que a tecnologia dos transportes opera radicalmente na convergência de tempo-espaço, mas que a isso se impõe o acesso que o grupo ou o indivíduo possui sobre esse recurso, tanto financeiro quanto da disponibilidade de assentos, como ilustra o autor: “[...] um trem expresso pode ligar duas cidades num tempo de três horas. Mas a disponibilidade de lugares pode ser limitada, mesmo para aqueles que podem e estão dispostos a pagar”. (GIDDENS, 1989, p.92)

Milton Santos (2008) acentua a necessidade de um olhar crítico sobre algumas fábulas criadas sobre a globalização e a contemporaneidade, como a criação do termo "aldeia-global" e a concepção de que existe um encurtamento das distâncias, pontuando que isso apenas ocorre para aqueles que têm acesso aos recursos ou podem pagar por eles, seja nos transportes, seja nas informações.

Assim, por exemplo, um estudante que sai da cidade de Madre de Deus, pequena ilha com pouco mais de 11 quilômetros quadrados e apenas 15.432 habitantes, em 2007, segundo dados do IBGE, teria, à sua disposição, trinta e nove opções de horários de viagem durante o dia, tanto para ir quanto para voltar de Salvador, além de outros dois ônibus disponibilizados pela prefeitura da cidade aos estudantes, que atendem 
aos que estudam pela manhã e pela noite. Aqueles que estudam à tarde recebem vale-transporte. Nota-se, portanto, que um estudante dessa pequena cidade possui acesso ao transporte e encontra-se em uma relação de estreita convergência tempo-espacial com Salvador e, muito provavelmente, tanto ele como seus familiares e amigos, já visitaram a cidade em momentos anteriores à entrada dele na universidade.

Por outro lado, um estudante que chega de uma cidade com menor acesso à capital, terá em seu histórico pessoal, familiar e das pessoas com quem partilha esse território, poucas visitas, vivências e vínculos com uma metrópole. Observa-se um estranhamento, tanto na chegada daquele que migra, quanto em seu retorno após um momento de afiliação à nova cidade. Ecléa Bosi (1987, p. 75) nos traz seu exemplo, ao relatar nesse fragmento, com os olhos da cidade grande, sua pequena comunidade de origem:

Há casas em cidades tranqüilas em que o tempo parou; o relógio das salas é o mesmo que pulsava antigamente e as pessoas que pisam as tábuas largas do assoalho conservam um forte estilo de vida que nos surpreende pela continuidade. Ainda na Semana Santa, em minha cidade, o jejum da "sexta-feira maior" é preparado dias antes com abundante comezaina (menos carne) para a penitência do grande dia. A farinha de milho do cuscuz é preparada pelos mesmos processos, exposta, vendida, cozinhada e comida com a mesma unção. E o manto do Senhor Morto das procissões é feito cada ano por mãos diferentes de costureiras, mas não é o mesmo gesto, a mesma devoção, o mesmo arrebatamento estético que absolutamente não são mais dos dias de hoje?

Aqui se observa a contribuição de Aristóteles, entendendo a passagem de tempo através das mudanças. Ecléa Bosi (1987), ao visitar sua cidade de origem, não encontrou muitas mudanças, mas sim uma surpreendente continuidade dos preparos, dos costumes e até mesmo dos gestos, dando-lhe a impressão de que o tempo parou, apesar do esforço do velho relógio das salas em querer demonstrar o tempo objetivo, ininterrupto, sempre-presente, inabalável. 


\section{O TEMPO, A CONTEMPORANEIDADE E O COTIDIANO}

Para Coulon (2008), quando da entrada dos estudantes na vida universitária, entram em jogo três modalidades diferentes, todas fundamentais no processo de afiliação do estudante ao contexto universitário e que sofreram intensas transformações nessa passagem ao ensino superior, que são as questões de tempo, de espaço e das regras do saber. Questões relativas ao espaço e ao tempo são importantes em todo o processo de afiliação, nas relações práticas da vida do estudante: prazos das provas, das inscrições, das matrículas, tempo das aulas dilatado, volume de estudo, ritmo de trabalho, espaços de convivência, distâncias entre instituições, deslocamentos, universidade como um espaço imenso perto dos colégios, dificuldades de localização.

Para Harvey (2009), têm-se vivido duas décadas de intensa "compressão do tempo-espaço" que tem impacto direto sobre as práticas políticas e econômicas, bem como sobre a vida social e cultural. $\mathrm{O}$ autor aponta como importante, nesse processo, a aceleração do tempo de giro do capital, uma solução encontrada para os graves problemas do fordismo da década de 70 , que teve inúmeras consequências para os trabalhadores, como a aceleração da desqualificação e da requalificação, para se atender às novas necessidades do trabalho. Com a necessidade de maior velocidade no giro da produção, tornou-se evidente a urgência da aceleração do consumo, da racionalização das técnicas de distribuição, da circulação de mercadorias, e das condições de pagamento. Para possibilitar esse processo, investiu-se na mobilização da moda em mercados de massa em oposição aos mercados de elite, e uma diminuição do "tempo de vida" dos bens e dos serviços.

Ainda segundo Harvey (2009), essas mudanças e acelerações trouxeram diversas consequências para as maneiras pós-modernas de pensar, sentir e agir, tais como: o acento na volatilidade e efemeridade de tudo (modas, produtos, valores, ideias, trabalho, práticas); a instantaneidade (de alimentos, de refeições); a descartabilidade (guardanapos, pratos, estilos de vida, relacionamentos etc.); o bloqueio dos estímulos sensoriais; a negação e o cultivo da atitude blasé; a especialização 
míope; a dificuldade em planejamentos de longo prazo; a manipulação do gosto e da opinião.

O tempo cada vez mais é visto pela perspectiva de sua escassez e de seu valor de mercado, constituindo-se moeda de troca que se empenha, basicamente, para alcançar recursos financeiros. O emprego do tempo tem-se justificado na medida em que este aproxima o indivíduo de seus objetos de desejo, renovados pela publicidade e pelo mercado de consumo, sempre mais velozmente do que a capacidade de compra. Somados a isso, os altos índices de desemprego, a instabilidade do mercado e a consequente insegurança dos trabalhos temporários levam o trabalhador a uma busca infinita por especialização e formação continuada, que o coloca em situação de competitividade entre seus iguais, que acabam por consumir as últimas migalhas de tempo a que teriam direito.

A relação dos indivíduos entre si, com a cidade ou com os espaços de modo geral, está comprometida com esse contexto tenso de deslocamentos acelerados pelas vias rápidas disponíveis. A permanência, nesse caso, opera como desperdício, como erro estratégico, por ter escolhido ruas engarrafas ou horários de intensa circulação. O interesse não repousa nos locais de passagem, mas exclusivamente nos pontos de chegada, que, por sua vez, nunca garantem repouso, mas somente uma estação de partida para a próxima viagem.

Habituados com a velocidade e com a pressa, nossos olhares perdem a capacidade de se ocupar com os detalhes, e desenvolvemos uma intolerância em aguardar ou depender de processos mais lentos do que a instantaneidade com que estamos nos acostumando. Olhares daqueles que chegam de outros contextos, que estão com suas expectativas e objetividades em suspensão, mesmo que provisoriamente, acabam por trazer informações valiosas, invisíveis e muitas vezes embaraçosas para aqueles habituados na rotina do local. Assim ocorre com os estrangeiros, sejam eles turistas, crianças ou palhaços, que acabam por oferecer visões muito deslocadas daquelas a que nos acostumamos coletivamente. 
Bosi (1987), ao falar sobre a narração, comenta que a arte de narrar vai decaindo com o triunfo da informação de imprensa, que não é pesada e medida pelo bom senso do leitor, como também possui uma descartabilidade imediata, uma vez que só é atraente enquanto novidade, enquanto que a narração está concentrada em limites "como a da semente e se expandirá por tempo indefinido" (BOSI, 1987, p. 87). A autora também comenta a falta de memória que afeta o receptor da comunicação de massa, justamente pelo “[...] excesso de informações que saturam sua fome de conhecer, incham sem nutrir, pois não há lenta mastigação e assimilação". (BOSI, 1987, p. 87)

Larrosa (2002) e Bosi (1987) observam que o homem contemporâneo encontra-se tão ocupado com o excesso de informações, que perdeu a capacidade da escuta atenta, do silêncio e da memória. A produção de memória estaria comprometida devido às características dessas informações vinculadas, que de tão efêmeras, não deixariam marcas suficientes em seus ouvintes para sua rememoração além dos instantes imediatos. Ao invés disso, toda a atenção se deslocaria à próxima informação. Para Bosi, "O homem moderno não cultiva o que ele pode simplificar e abreviar [...]” (1987, p. 88). Milton Santos (2008) traz para esse diálogo a compreensão de que esse processo é fundamental no funcionamento atual da economia global, interligada com a produção de informação, com a publicidade, a violência, a competitividade, e a compressão de tempo-espaço. Intrincada com a publicidade, a difusão imediata de notícias não tem compromisso em informar as pessoas, mas antes de confundi-las, e, assim, dominá-las. Esse domínio pela informação e pela "confusão dos espíritos" aparece na adesão irrestrita dos "consumidores" à tirania do dinheiro, do consumo, da informação, e da competitividade. De um lado, a competitividade comandando nossas formas de ação, e do outro, o consumismo comandando nossas formas de inação (SANTOS, M., 2008).

A concorrência que existia anteriormente foi substituída pela competitividade. A guerra é a norma nesse novo modo de convivência, que se torna regra entre as pessoas, elimina toda forma de compaixão 
e impele, a todo custo, um indivíduo a vencer o outro, esmagando-o para tomar seu lugar. Como base desse processo, o autor aponta o individualismo arrebatador que constitui o outro como coisa, a perda de influência da filosofia na formulação das ciências sociais, o abandono da solidariedade, da educação e o aumento do desemprego, gerando uma violência estrutural. (SANTOS, M., 2008)

Em decorrência do consumismo e da competitividade, Milton Santos (2008) observa um emagrecimento moral e intelectual das pessoas, borrando a distinção entre ser cidadão e ser consumidor, muito embora, segundo ele, no Brasil, nunca existiu a figura do cidadão, porque os pobres jamais puderam ser cidadãos, e os ricos e aqueles que pertencem à classe média jamais quiseram ser cidadãos, foram condicionados a apenas querer privilégios e não direitos.

As consequências pessoais do trabalho no capitalismo flexível foram discutidas por Sennett (2008), e caminham na mesma direção dos argumentos apresentados até agora. A nova lógica da flexibilidade trouxe novas maneiras de organizar o tempo que influenciam diretamente a vida das pessoas. Sennett (2008) afirma que, acima de tudo, é a dimensão do tempo no novo capitalismo que mais diretamente afeta a vida emocional das pessoas, e não a transmissão de dados high-tech, os mercados de ação globais ou o livre comércio. Criou-se um lema no mundo dos negócios de que "não há longo prazo", sendo assim, as empresas fundem-se, fragmentam-se, despedem, contratam, sem os compromissos sociais sobre os quais já falamos anteriormente. Esse lema, no cotidiano dos laços afetivos, das amizades ou da família, para o autor, significa mudar, não se comprometer e não se sacrificar, além de corroer a confiança, a lealdade, o compromisso mútuo, e o caráter: “[...] o capitalismo de curto prazo corrói o caráter [...], sobretudo, aquelas qualidades de caráter que ligam os seres humanos uns aos outros e dão, a cada um deles, um senso de identidade sustentável [...]”. (SENNETT, 2008, p. 27)

Bauman (2001) contribui para o entendimento do esvaziamento dos pactos coletivos, entendendo que há uma redefinição da esfera 
pública como um palco de dramas privados, publicamente expostos e assistidos. A política, que outrora era a atividade de tradução dos problemas privados em questões públicas e destas em problemas privados, desaparece, porque o simples fato de se exporem questões individuais não a transforma em categoria mais ampla. As questões, hoje consideradas públicas, são os escândalos, "problemas privados de figuras públicas", encenados em larga escala através dos "espetáculos de sinceridade" - rituais de perguntas pessoais e confissões -, cujos atores sob os holofotes são esportistas, estrelas do cinema, ministros do governo. Com a fragilidade das questões públicas e o imperativo de criar-se a si mesmo em um universo imenso de possibilidades e direções, Bauman (2001) compreende que essa tarefa comum a todos, mas individualizada como compromisso pessoal e intransferível, induz à competição ríspida e fragiliza as possibilidades de cooperação e de solidariedade.

O fim da era do engajamento mútuo, com a desintegração da rede social, das ações coletivas, não é apenas o resultado de uma nova técnica de poder, mas antes a condição desse novo modelo. As redes afetivas funcionam como barreiras para um poder que se quer fluido, desengajado, fugaz, livre de cercas e de fronteiras. (BAUMAN, 2001)

\section{CONCLUSÕES E PROPOSTAS}

Pensar a universidade hoje é pensar a contemporaneidade e as relações estreitas que esta possui com macroestruturas e com nosso cotidiano. A universidade, ao permanecer à parte das discussões que envolvem a consolidação do capitalismo flexível, da globalização, dos mercados transnacionais e dos impactos dessas forças em sua nova condição diante do Estado e da sociedade, ata suas mãos às vontades alheias aos seus interesses, sem compreender, sem discutir, e, portanto, sem se posicionar no novo contexto que já se encontra instaurado ${ }^{2}$.

Desta forma, no estudo das relações da universidade com seus estudantes, e destes entre si, a instituição e a produção de conhecimen- 
to também necessitam ser consideradas no interior de uma discussão mais ampla, que leve em conta as novas práticas, discursos e forças, que percorrem as ruas e, sem cerimônia, já se encontram há muito tempo nas salas de aula, nas bibliotecas, cantinas e residências universitárias.

Se as questões de tempo e de espaço estão profundamente alteradas na contemporaneidade, isso certamente afeta a vida universitária. Os estudantes, os professores, os funcionários, estão expostos cotidianamente, por exemplo, ao que Harvey (2009) chamou de "tempo industrial”, que, associado a vigorosos ritmos de mudança tecnológica, imprime um impulso geral sempre para a frente e para o alto, num padrão único e irresistível da flecha do movimento do tempo.

Lançados na velocidade vertiginosa da aceleração contemporânea, em busca de algo sempre distante de nossos pés, Bauman (2001) e Larrosa (2002) nos lembram de que ser moderno é ser incapaz de parar e de ficar parado. A corrida vale por si mesma, e, por mais cansativa que seja, a pista é sempre um lugar mais agradável do que a linha de chegada.

A cidade, como a própria vida do sujeito, foi transformada em pista de corrida, sem descanso, sem lugar seguro, sem alvo que não se movimente mais veloz do que suas forças, sem vontade que se realize mais depressa do que as novas ofertas na prateleira do consumo, sem especialização que se conclua antes dos novos cursos "indispensáveis" no rentável comércio da educação. A competitividade e o individualismo, nessa ambiência, tornaram-se lugar comum, natural, corriqueiro, mas estão esfarelando as relações de confiança, lealdade, cumplicidade, compromisso mútuo e de possibilidade de ações coletivas sobre as questões públicas.

Assim, como pensar um estudante que não atravesse as mesmas questões no fazer acadêmico, e, portanto, no processo de tornar-se estudante? Correr mais depressa de que os outros estudantes é uma tarefa a mais na agenda? Vivenciar os espaços acadêmicos se empobrece a ponto de se tornar, cada vez mais, uma disputa por um lugar na fila, para reproduzir um texto; pegar um livro na biblioteca, antes que os 
demais peguem todos; participar de uma competição velada, em que se colecionam certificados para o currículo, em que se omitem informações de oportunidade de estágio, de bolsa de estudos, de intercâmbio?

Uma das bases dessa competição no contexto brasileiro é de que não há vagas para todos. $\mathrm{O}$ acesso à educação universitária já é restrito e difícil, mas a disputa continua mesmo após se vencer essa primeira barreira, quando o estudante se depara com a necessidade de utilizar os bens de que a instituição dispõe, como as vagas de estágio, as bolsas de estudo, as bolsas alimentação, os livros na biblioteca, as vagas em um curso etc. De modo muito semelhante, observa-se essa mesma disputa espacial com relação aos leitos de um hospital, às vagas nas escolas públicas, nas creches (universitárias ou não), e até mesmo nas penitenciárias superlotadas. Cotidianamente, os carros disputam milimetricamente os espaços nas ruas congestionadas, os usuários de restaurantes disputam o número sempre insuficiente de mesas, os carros disputam vagas para estacionar, em uma corrida impulsionada pela certeza de que não há lugar para todos. Assim, assistimos à gentileza e à cidadania serem corroídas por forças brutais, masculinizadas, impositivas, intolerantes com a demora, com a deficiência e com a diferença. Exige-se uma atitude viril, ágil, com prontidão servil para avançar o mais rápido possível, mesmo que isso interfira nos espaços públicos, nas regras, nos direitos e nos espaços de outrem.

É nesse contexto que as propostas de Larrosa (2002) parecem pertinentes e desafiadoras, precisamente por lançar-se na contramão das forças impositivas, viris e rudes. A experiência que Larrosa (2002) propõe parece exigir um tempo sem utilidade ou pressa, alongando-se em pausas e silêncios, tendo como princípio um sujeito mais disponível, mais aberto, mais receptivo; de uma passividade feita de atenção, paixão; exposto ao novo e aos riscos das novas travessias, aos olhares de estrangeiro, demorando-se nos detalhes, dando-se tempo para olhar, escutar, sentir e suspender o automatismo, a pressa do juízo e da vontade.

Essa proposta possui impacto imediato no cotidiano universitário, na qualidade das relações entre os estudantes, por exemplo, mas tam- 
bém na relação e na construção do conhecimento. Um conhecimento não mais voltado para a acumulação infinita e insaciável de informações, mas comprometido e entrelaçado com a existência e, como tal, inseparável do indivíduo que a vivencia, implicando em produções singulares, heterogêneas e plurais. Comprometer-se com um "saber da experiência" é lançar-se da mesma forma como um estrangeiro que chega a um novo país ou a uma nova cidade, em que os sentidos estão disponíveis para desvelar e conhecer o que já é natural e indiferente para os habitantes locais, assim como os "espaços vazios" (BAUMAN, 2001), é encontrar-se em travessia, exposto, disponível.

Com uma arrogância não isenta de certa vontade de provocação, Nietzsche exige para si mesmo "leitores perfeitos, filólogos rigorosos", pessoas capazes de "ler devagar, com profundidade, com intenção profunda, abertamente e com olhos e dedos delicados". Sabe que a arte da leitura é rara nesta época de trabalho e de precipitação, na qual temos que acabar tudo rapidamente. Os "leitores modernos" já não têm tempo de esbanjar em atividades que demorem, cujos fins não se vêem com clareza, e das quais não podem colher imediatamente os resultados. (LARROSA, 2005, p. 14)

Larrosa (2005) continua comentando que os leitores contemporâneos só se dedicam a uma leitura interessados em uma atividade futura, como a escrita de uma resenha, um trabalho, um próximo livro, de consumo rápido. $\mathrm{O}$ autor propõe uma leitura lenta, descompromissa$\mathrm{da}$, em profundidade, tomando tempo, sem uma intencionalidade imediata, ou ainda, sem esperar nada em troca.

Desta forma, Larrosa (2005) também nos provoca pensar sobre as práticas da universidade e, então, podemos retomar o ponto que trouxemos de Coulon (2008) no início do capítulo, quando ele se refere à quase ausência de uma pedagogia universitária. À primeira vista, pensar na proposta de Larrosa (2005) para a universidade parece ser absurdo, justamente pelo fato da indiferença pedagógica desta para com os processos vividos pelos estudantes, no que ignora o exigente trabalho de aprendizado do ofício de estudante que todo calouro precisa operar. 
Ao ler com atenção o livro de Coulon (2008), identificamos propostas para uma "pedagogia da afiliação", na qual a universidade deve favorecer e não dificultar o processo de passagem para a condição de estudante, marcada por intensas rupturas. A universidade pode - propõe o sociólogo francês - semestralizar o ensino no primeiro ano, orientar seus professores para um maior cuidado e indulgência com os trabalhos e avaliações de calouros, contribuindo, assim, para a transição entre práticas, tão distantes, como as do ensino médio e aquelas do ensino superior. Além disso, os professores podem acompanhar seus alunos quanto às possíveis trajetórias dentro da universidade, oferecendo apoios que façam progredir seu processo de afiliação.

Podemos acrescentar ainda, cuidados da universidade com as políticas de acesso e de permanência, viabilizando economicamente a permanência com bolsas de estudo, de moradia e de alimentação, fomentar as discussões sobre a própria universidade através de grupos de estudo, de linhas de pesquisa, congressos e programas de pós-graduação, além de se repensar as pedagogias para o espaço e o tempo universitários. Como discutimos anteriormente, a universidade necessita expandir o acesso aos seus serviços, para além do número de vagas atualmente disponíveis, mas também garantir equipamentos de qualidade, como, por exemplo, bibliotecas bem equipadas, centros de informática com uso garantido, sem o recurso à mendicância ou sujeição a longas filas de espera, e aparato administrativo capaz de disponibilizar informações claras aos estudantes.

A dimensão espacial será tocada, mais demoradamente, em outro texto deste livro, quando discutiremos a interdição do Pátio Raul Seixas para reforma de um dos prédios da Faculdade de Filosofia e Ciências Humanas da UFBA. Porém, desde já, acrescentamos que a universidade tanto pode contribuir para o processo de afiliação como dificultá-lo através da criação ou da manutenção de espaços que acolham atividades e encontros dos universitários, professores e funcionários. As preocupações da universidade não devem se restringir à garantia do número de salas suficiente, em meio a uma arquitetura indiferente, que 
perde de vista a necessidade do estudante permanecer mais tempo na universidade e exercitar laços de proximidade com a instituição e com os outros estudantes. Ao contrário da ideia de intimidade, a nova arquitetura, que invade também as universidades, está disposta, segundo as definições de Bauman (2001), sobre os "não-lugares", que desencorajam a vontade de permanecer, de criar relações e preenchê-los de expressões simbólicas.

Podemos pensar também nas inúmeras implicações de como a universidade poderia dispor do tempo. Porém, finalizando, tocamos nas práticas correntes entre professores, que poderiam repensar a qualidade e o volume de leituras e trabalhos exigidos, privilegiando a utilização mais profunda e cuidadosa das leituras, e não se limitando a atividades em que se sentem qualificados em sua função, ao impor uma infinidade de textos que serão tratados displicentemente e sem o necessário acompanhamento dos processos de apropriação das leituras pelos alunos.

Se a pressa, a competitividade e a alta velocidade são condições atuais de relação nas grandes cidades, como a universidade deve posicionar-se? A universidade, enfim, freia os processos de aceleração, de competição e de pauperização das relações sociais, ou estaria, ao contrário, contribuindo ainda mais para a sua multiplicação?

\section{REFERÊNCIAS}

ALMEIDA FILHO, Naomar. Universidade Nova: textos críticos e esperançosos. Salvador: EDUFBA, 2007.

AGOSTINHO, Santo. Vida e Obra. São Paulo: Editora Nova Cultural, 1999. BOSI, Ecléa. Memória e Sociedade: lembranças de velhos. São Paulo: EDUSP, 1987.

BAUMAN, Zygmunt. Modernidade Líquida. Rio de Janeiro: Jorge Zahar Ed., 2001.

COULON, Alain. A Condição de Estudante: a entrada na vida universitária. Salvador: EDUFBA, 2008. 
COMTE-SPONVILLE, André. O Ser-Tempo: reflexões sobre o tempo da consciência. São Paulo: Martins Fontes, 2006.

ELIAS, Norbert. Sobre o Tempo. Rio de Janeiro: Jorge Zahar Ed., 1998.

GIDDENS, Anthony. A Constituição da Sociedade. São Paulo: Martins Fontes, 1989.

HARVEY, David. Condição Pós-Moderna. São Paulo: Edições Loyola, 2009.

LARROSA, Jorge Bondía. Nietzsche e a Educação. Belo Horizonte: Autêntica, 2005.

. Notas sobre a experiência e o saber de experiência. Revista

Brasileira de Educação, n. 19, p. 20-28, 2002.

SANTOS, Boaventura de Souza. A Universidade do século XXI: Para uma reforma democrática e emancipatória da Universidade. Educação, Sociedade e Culturas, n. 23, 2005. Disponível em: <http://www.ces.uc.pt/bss/ documentos/auniversidadedosecXXI.pdf.> Acesso em: 07 maio 2010. SANTOS, Milton. Por uma outra Globalização: do pensamento único à consciência universal. Rio de Janeiro: Record, 2008.

SENNETT, Richard. A Corrosão do Caráter: consequências pessoais do trabalho no novo capitalismo. Rio de Janeiro: Record, 2008. 


\section{UM NOVO UNIVERSITÁRIO \\ estudantes de origem popular na Ufba}

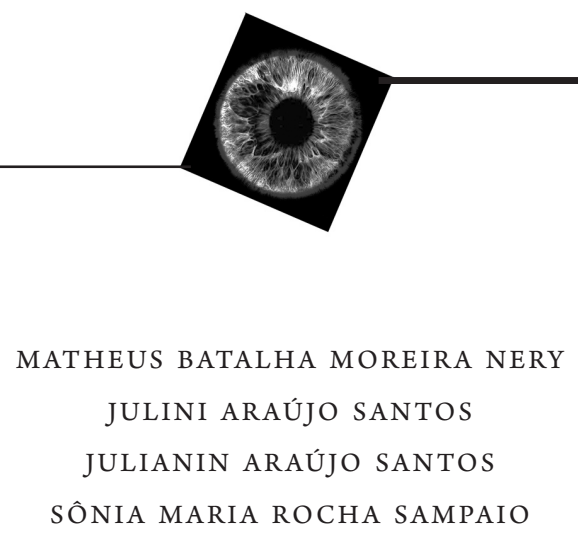

A EDUCAÇÃO SUPERIOR NO BRASIL E NA BAHIA: COMEÇO E DESENVOLVIMENTO

O acesso a universidades, no período colonial brasileiro, ficou restrito aos jovens da elite, oriundos de famílias abastadas, que tinham condições de enviar seus filhos para realizar estudos superiores na Europa. No período que antecede à transferência da família real portuguesa para o Brasil, o governo português manteve uma política de controle que tentou suprimir qualquer sinal de independência cultural e política da colônia (FÁVERO, 2006), gerando um relativo isolamento cultural e intelectual e um retraimento de 308 anos, no qual nenhuma ideia de educação superior ou de universidade pôde ser desenvolvida. 
Um projeto de educação superior só pôde tomar forma após vários anos de debate político e do avanço na discussão de alguns temas considerados centrais para a sociedade na época. (BARRETO; FIGUEIRAS, 2007) A concepção dos primeiros projetos de educação superior no Brasil é uma mistura entre dois modelos ocidentais de universidade. $\mathrm{O}$ primeiro, e mais antigo, teve como base o Relatório Humboldt de 1810, que estabelecia o primado da pesquisa científica na vida universitária. Este documento organizou os alicerces fundamentais para a criação da Universidade de Berlim. Sua principal base era a consolidação do sistema de cátedras como componente fundamental da gestão acadêmica, no qual estariam incluídos elementos da governança institucional e a distribuição e separação entre campos de conhecimento.

Um segundo modelo resulta da reforma universitária norte-americana, do início do século XX, a partir do Relatório Flexner. Esse documento tinha como foco a formação na área de saúde, mas também abordava pontos importantes para a reorganização do sistema universitário americano. $\mathrm{O}$ centro dessa reforma foi a adoção de uma arquitetura acadêmica que era composta por uma formação básica e flexível, denominada de undergraduate college, que dava possibilidade ao estudante ingressar em uma formação profissionalizante e a uma especialização no campo disciplinar. Na parte organizacional, instituiu-se uma separação entre a gestão institucional, delegada aos Deans (nomeados chefes de escolas e faculdades), e a governança acadêmica, conduzida por departamentos compostos por professores titulares. (ALMEIDA FILHO, 2007)

O isolamento cultural imposto por Portugal ao Brasil gerou consequências na posterior organização das universidades brasileiras, na sua composição institucional e no público que atendiam. Nas constituições de 1934 e de 1946, a universidade pública brasileira aparece representada através de uma composição institucional organizada por vários segmentos ligados a um núcleo central, tal qual ilhas que dependiam de uma administração centralizada. A população alvo das universidades continuava a ser as elites, que passavam a não precisar mais se deslocar para o exterior em busca de educação. (FÁVERO, 2006) 
Nesse contexto, a instituição Universidade da Bahia nasce através do decreto-lei no 9.155, de 8 de abril de 1946. Este documento designava a unificação de cinco escolas públicas de ensino superior: Faculdade de Medicina, Faculdade de Direito, Escola de Belas Artes, Escola Politécnica e a Faculdade de Filosofia. A primeira foi fundada em 1808, quase 140 anos antes da criação da universidade, sob o nome de Centro Médico de Cirurgia da Bahia. Dentre os modelos ocidentais de universidade, o sistema adotado pela então Universidade da Bahia, em 1946, era o regime de cátedra autárquica, com clara inspiração no modelo de gestão universitária proposto pelo Relatório Humboldt.

Nos anos que se seguiram, o modelo adotado pela então Universidade da Bahia, considerado centralizador, tornou-se alvo de debates e críticas. A partir do início dos anos 1960, foi pensado um modelo inovador para a Universidade de Brasília (UnB), que serviria à nova capital brasileira. A proposta foi construída sob uma concepção modernizadora que visava uma maior autonomia e integração da instituição universitária, substituindo a divisão tradicional em faculdades isoladas e cátedras autárquicas por um modelo organizacional que integrava ensino, pesquisa e extensão. (RIBEIRO, 1978)

Nesse sentido, Ribeiro (1978) destaca que, para que a proposta obtivesse sucesso, quatro pontos centrais foram propostos como metas: a universidade deveria ter condições de formar e manter um quadro intelectual e cultural de alto nível; a prática da pesquisa científica deveria ser massivamente incorporada; a superação do modelo de isolamento das cátedras, devendo a universidade criar órgãos de integração da vida universitária; e, por fim, os problemas gerais da educação brasileira passariam a ser de interesse central da instituição, assumindo a universidade a tarefa de conhecer melhor sua população de estudantes.

Com o Golpe militar de 1964, o governo federal colocou em prática um projeto de modernização para todas as universidades do país, em que a educação passou a ser definida como "capital humano" e, por isso, deveria estar inserida no Plano de Ação Econômica, dirigido pelo Ministério do Planejamento e da Coordenação Econômica. Este 
projeto propunha o aumento significativo do número de estudantes matriculados nas universidades públicas, uma verdadeira injeção de seres humanos capazes de desenvolver atividades produtivas na sociedade brasileira. (CUNHA, 2007) O critério para o planejamento das novas vagas somente considerava o número de jovens residentes em municípios com mais de 50 mil habitantes. Dessa maneira, foi estimada a necessidade de criação de 180 mil novas vagas nas universidades públicas. A ideia era que a universidade tivesse um estudante para cada 100 habitantes.

A proposta do projeto de modernização não levava em consideração as demandas dos setores econômicos para a formação de profissionais, nem as expectativas da população, porque somente considerou que um segmento específico era capaz de pleitear vagas. A noção de políticas afirmativas, ou mesmo de ampliação da possibilidade de acesso ao ensino superior por pessoas de origem popular não foi discutida nessa ocasião. (CUNHA, 2007)

O modelo introduzido pela Universidade de Brasília foi repudiado pelos que lideravam o movimento de reforma para a modernização das universidades brasileiras, críticos que eram em relação à liberdade e à autonomia dada a alguns segmentos da vida universitária. Além disso, o projeto da UnB era visto como uma crítica ao modelo adotado pela outras universidades. Embora tenha obtido sucesso, seus articuladores haviam sido isolados pelo governo militar e não participariam da elaboração do novo plano nacional. A UnB foi ocupada pelos militares em 1964 e uma grande quantidade de professores e pesquisadores foi demitida. (ALMEIDA FILHO, 2007; CUNHA, 2007)

O projeto de modernização das universidades do país culminou na Lei da Reforma Universitária, no 5540 de 1968, documento que ordenou e padronizou a composição organizacional das universidades brasileiras. Diante deste contexto, Fávero (2006) observa que o projeto foi construído em torno de um núcleo central de ideias em que se destacavam a substituição do antigo regime de cátedras pelo departamental, a realização de um vestibular unificado e classificatório para todos 
os cursos, a criação de um ciclo básico, de um sistema de matrículas por disciplina e a concepção de um plano de carreira para o magistério.

Com um número significativo de investimento financeiro, este modelo, introduzido em 1968, proporcionou um grande crescimento para a universidade brasileira, que passou a ocupar um lugar central no desenvolvimento da atividade nacional de pesquisa. Por outro lado, esse projeto não destacou, nem criou instrumentos que proporcionassem uma articulação ativa entre a universidade, a sociedade e o setor produtivo. Essa ponte somente foi feita, ainda de forma desordenada, anos mais tarde, pela necessidade que o mercado teve de consumir os produtos intelectuais que a academia produzia. (MACEDO, 2005)

Ao refletir sobre essa reforma, Almeida Filho (2007) destaca dois fatores: o primeiro é que o projeto somente abarcou as partes menos interessantes do Relatório Flexner, utilizando alguns de seus conceitos sem que estes resultassem em alguma transformação social, como, por exemplo, a mera substituição das cátedras autárquicas por departamentos, sem descentralizar a gestão da vida acadêmica; o segundo fator, visto como positivo e relevante, foi a implementação de uma rede institucional de pós-graduação e a ampliação de incentivos à pesquisa científica, possibilitando que a universidade pública brasileira formasse pesquisadores.

Foi através da reforma de 1968, que a Universidade da Bahia passou a ser conhecida pela designação atual, Universidade Federal da Bahia (UFBA), o que contribuiu, significativamente, para o seu desenvolvimento. Atualmente a instituição conta com 32 unidades acadêmicas de ensino, pesquisa e extensão, sendo duas delas localizadas no interior do Estado, nos municípios de Barreiras e Vitória da Conquista. Seus números, divulgados em seu endereço eletrônico na internet, em 2009, falam da sua importância: existem 66 cursos de graduação, 55 de mestrado, 38 de doutorado, 35 especializações, 29 especialidades de residência médica; 24.075 alunos matriculados em cursos de graduação, 2.163 em cursos de mestrado e 1.096 em cursos de doutorado; o quadro permanente conta com 1.733 professores e 3.312 servidores; a 
universidade possui 121 edificações e, o último orçamento aprovado, foi de R\$ 783.569.065,00.

\section{A UFBA E SEU COMPROMISSO SOCIAL}

No ano de 2004, o Conselho Superior da UFBA instituiu um grupo de trabalho encarregado de conceber um Plano de Desenvolvimento Institucional. Após as deliberações, essa instância aprovou a necessidade de uma nova reforma em sua estrutura, função e compromisso social. A decisão ganhou força quando o governo federal enviou o Anteprojeto de Lei no 7200 à Câmara dos Deputados Federais, que solicitava que os parlamentares discutissem e aprovassem uma reforma para as universidades públicas, que previa novas definições para a política de financiamento do ensino superior, regulação da política de cotas para estudantes de escolas públicas, negros e índios, e do Programa Universidade para Todos (PROUNI), além da introdução de dispositivos de monitoramento das universidades privadas, em uma tentativa de assegurar a qualidade de ensino. (LIMA; AZEVEDO; CATANI, 2008)

Entretanto, esta proposta somente incluiu fatores de ordem institucional e de regulação administrativa. Não se fez menção à modificação da arquitetura acadêmica. Essa possibilidade só foi concretizada através do Decreto Presidencial no 6096 do ano de 2007, que instituiu o Programa de Apoio a Planos de Reestruturação e Expansão das Universidades Públicas Federais (REUNI). Em seu Art. 10, este documento fixou como objetivo da política de educação do governo federal ampliar o acesso de estudantes à educação superior e consolidar a sua permanência nas universidades. É com essa ação, que o governo federal pretendeu melhorar o aproveitamento da estrutura física e dos recursos humanos destas instituições, além de ampliar as possibilidades de implementação de políticas de ações afirmativas e de programas que visem melhorar o acesso, a permanência e a convivência de estudantes universitários. (BRASIL, 2007) 
A discussão acerca das ações afirmativas e da reserva de vagas nas universidades públicas é um debate que se inicia na promulgação da Constituição Federal em 1988, em que o combate ao racismo, à discriminação racial, à xenofobia e à intolerância foi estabelecido. (MAGGIE; FRY, 2004) Posteriormente, esse debate foi aquecido, no ano de 2001, através da promulgação da primeira lei de reserva de vagas para negros nas universidades estaduais do Rio de Janeiro. Outros Estados, como a Bahia e Mato Grosso do Sul, logo seguiram essa decisão, o que possibilitou que outras instituições federais incluíssem o assunto nas suas agendas de discussão e incentivou a produção de trabalhos acadêmicos acerca do tema. (BEVILAQUA, 2005)

Críticas surgiram acerca das ações afirmativas e da reserva de vagas: algumas enfatizavam que o Brasil, país composto de grandes misturas, a partir do surgimento das novas políticas de acesso, estaria condenado a ser a nação dos que têm ou não direito à ação afirmativa; outras defendiam que a reserva de vagas representaria uma ruptura e um retrocesso em relação à tradição não racista brasileira e que esse dispositivo infringiria o caráter de igualdade de todos perante a lei, celebrado na Constituição Federal. Esse argumento, que ainda hoje tem seus representantes, não considera os longos anos em que vigorou a escravidão para os negros e a violência e o genocídio que dizimaram a expressiva maioria da população indígena nativa. $O$ fato é que, a despeito de muitas opiniões contrárias, a reserva de vagas nas universidades públicas foi implantada em muitas delas e hoje é uma realidade incontornável. (MAGGIE; FRY, 2004)

Estas novas propostas para as universidades modificaram as ações voltadas para a juventude no Brasil, sempre marcadas pelo equívoco de serem planejadas para dar conta de um segmento da população potencialmente perigoso ou propenso à violência. A falha mais importante dessas ações, que não podem ser chamadas de políticas, pelo seu caráter localizado e parcelar, reside na inexistência de uma agenda voltada para o acesso do jovem à educação, ao trabalho e a redes sociais, culturais e políticas. Tomar como eixo somente a violência e o desemprego, não 
possibilitou praticamente nenhum avanço para os jovens brasileiros de origem popular. (SPOSITO; CORROCHANO, 2005)

A partir da publicação do decreto que instituiu o REUNI, a UFBA construiu um plano de atuação para algumas áreas estratégicas visando o seu desenvolvimento. $\mathrm{O}$ projeto de reforma universitária desta instituição, aprovado pelo seu Conselho Universitário, em 2007, modificou estrategicamente alguns de seus aspectos fundamentais para melhorar o acesso, a evasão e a ocupação de vagas ociosas. Além disso, houve a interiorização da universidade, com a criação de campus universitários em Barreiras e Vitória da Conquista, a criação de cursos noturnos e o desenvolvimento de programas de ações afirmativas que atuam para fortalecer a permanência dos estudantes de origem popular na universidade. (UFBA, 2007)

Os dados mais recentes de evasão na UFBA datam de 1995 e não estabelecem relações entre variáveis neles implicadas; além de necessitar atualizar e modernizar o debate acerca do abandono dos estudos superiores, seus gestores, impulsionados também pelo próprio movimento da comunidade universitária, buscam desenvolver ações para ir além da discussão sobre o acesso à universidade. Em 2007, a UFBA contabilizou 5.400 estudantes de origem popular, com uma renda familiar de, no máximo, um salário-mínimo. Se esse número estiver correto, isto significa que a Universidade Federal da Bahia já alcançou números importantes em seu processo de democratização. Essa cifra dá uma nova aparência a essa instituição e a obriga a apresentar propostas claras e executáveis para que essa população possa concluir seus estudos superiores. (UFBA, 2007)

Intitulado inicialmente de Universidade Nova, o projeto de reforma universitária da UFBA foi alvo de longos debates, internos e externos, promovidos pelos múltiplos interessados na questão. Entre as críticas que mais tiveram eco estão as que enfatizam que a expansão de vagas universitárias não seria acompanhada de melhorias na infraestrutura, que os novos estudantes conviveriam com os mesmos problemas enfrentados pelos atuais, ou ainda que o projeto estipulou metas inalcan- 
çáveis e que a assistência estudantil estaria colocada em segundo plano com estratégias pouco eficientes que não melhorariam as condições de permanência dos estudantes na universidade. Todas essas críticas nos parecem contempladas pela proposta de reforma da universidade. A assistência estudantil que, por muitos anos, atuou com um foco limitado, tem tido participação ativa na consolidação das metas do projeto, principalmente no que concerne à permanência dos estudantes no contexto universitário. (UFBA, 2007)

As ações voltadas para a permanência objetivam dar apoio aos universitários, para que eles tenham melhores condições para se dedicarem aos seus estudos. No ano de 2006, a UFBA criou a Pró-Reitoria de Assistência Estudantil (PROAE), em substituição à antiga Superintendência Estudantil, para ampliar o seu foco de atuação e suprir as demandas por assistência aos estudantes. A justificativa para criação da PROAE encontra-se, principalmente, no aumento do número de estudantes que realizaram o ensino médio em escolas públicas e foram aprovados no concurso vestibular. A partir de 2005, esse contingente aumentou significativamente em relação ao número de estudantes de escolas particulares aprovados, considerando os anos anteriores, demonstrando uma mudança significativa na população de universitários da UFBA ${ }^{1}$. Para a criação e o gerenciamento de projetos voltados para o fortalecimento de ações voltadas para esse segmento específico, foi criada a Coordenação de Ações Afirmativas, Educação e Diversidade.

Esta coordenação criou, em 2007, o Programa Permanecer, com o objetivo principal de assegurar a permanência dos estudantes socioeconomicamente vulneráveis e que poderiam interromper seus estudos ao encontrarem situações adversas no contexto da universidade. No Programa Permanecer, os Professores e os Técnicos Administrativos podem inscrever projetos em três eixos: extensão universitária, voltado para projetos que estabeleçam relação entre a universidade e a sociedade; institucional, que visa dar suporte a projetos de natureza técnico-

1 As informações foram colhidas no documento PROPLAD - demanda social, disponibilizado pela Pró-Reitoria de Extensão/UFBA. 
administrativa e artístico-cultural e apoio à docência, monitoria para o acompanhamento de componentes curriculares de cursos de graduação. (UFBA, 2007)

O Programa disponibiliza 600 bolsas e funciona através do sistema de contrapartida, ou seja, a universidade disponibiliza o valor de $\mathrm{R} \$ 300,00$ (trezentos reais) aos estudantes, como forma de auxílio financeiro, e, em troca, os participantes devem cumprir todas as exigências estipuladas pela gerência do programa, entre elas a de cumprir vinte horas semanais em atividades supervisionadas pelos coordenadores que tiveram seus projetos contemplados com bolsas. A exigência de contrapartida em projetos sociais foi objeto de análise de Sposito e Corrochano (2005), que destacaram a importância desse mecanismo como um agente que rompe com o viés, meramente assistencialista, de muitas propostas sociais. Essas iniciativas demandariam o estímulo ao engajamento ativo e à busca por independência por parte dos participantes. Mas, ao mesmo tempo em que informam essas vantagens, as autoras advertem que a ideia de contrapartida é um conceito multifacetado, que engloba desde o âmbito mais restrito, como a exigência da frequência escolar, ao mais complexo, como tarefas que poderiam sobrecarregar os participantes, impedindo-os de atingir as competências individuais planejadas para o processo.

No caso do Programa Permanecer, todas as atividades desenvolvidas pelos bolsistas devem contribuir para sua formação acadêmica, principalmente porque ele não visa somente dar assistência financeira aos estudantes. $\mathrm{O}$ estudante selecionado para fazer parte do programa deve permanecer matriculado em seu curso de graduação durante todo o período de vigência da bolsa, sendo que as atividades desenvolvidas devem, necessariamente, contribuir para sua formação acadêmica e pessoal.

Os 600 estudantes que participam dessa iniciativa da PROAE, além da informação vaga de que pertencem aos segmentos populares são pouco conhecidos, como de resto também o é o conjunto dos estudantes que frequentam a UFBA. Interessados nas transformações do 
perfil da população que frequenta essa universidade, desenvolvemos um projeto de pesquisa, cujos resultados iniciais este artigo apresenta, para conhecer as principais características sociodemográficas dos bolsistas do Programa Permanecer, primeiro passo para avaliar as implicações e impactos da existência desse programa específico da Universidade Federal da Bahia.

\section{COMO FOI REALIZADO O ESTUDO}

Devido à dificuldade de contato presencial com esse número de bolsistas, a coleta de dados foi realizada por via eletrônica. Tomando como base modelos de pesquisa survey, todos os 511 bolsistas que possuíam endereços catalogados receberam, através de um e-mail criado para a pesquisa, uma correspondência em que o pesquisador os convidava a participar e explicava a finalidade do instrumento e a relevância das respostas para a compreensão do fenômeno da permanência estudantil.

O instrumento, um questionário sociodemográfico, foi construído com o objetivo de levantar as principais características desta população de estudantes. Ele teve como base o questionário utilizado pela UFBA para coletar informações dos estudantes no momento da inscrição para o vestibular. Assim, foi composto por quarenta e seis itens que questionavam aspectos relacionados à vida acadêmica: utilização e acesso a conhecimentos através da internet; principais características da formação nos ensinos fundamental e médio; como se deu o acesso à universidade; expectativas em relação ao curso, à formação educacional, à vida econômica da família e à utilização do recurso financeiro (bolsa) disponibilizado pelo Programa.

Dessa forma, em média, um a cada dois estudantes que receberam o e-mail, convidando para participar da pesquisa, respondeu ao instrumento, somando 252 questionários coletados. Dillman, Smyth e Christian (2007), ao analisarem a utilidade da internet para pesquisas científicas destacaram que esta ferramenta tem apresentado uma curva ascendente no número de respostas dos participantes. Eles argumen- 
tam que isto se deve ao fato da rede virtual ter se tornado parte do cotidiano das pessoas e da facilidade e comodidade que ela propicia ao possível participante da pesquisa.

Os dados foram codificados e digitados em um banco de dados no software Statistical Package for Social Sciences (SPSS 15.0), permitindo que o grupo de estudantes, como um todo, fosse tomado como uma unidade de análise, sendo os dados submetidos a análises descritivas.

\section{A POPULAÇÃO DE BOLSISTAS DO PROGRAMA PERMANECER}

A distribuição dos participantes pelas áreas acadêmicas apresentou uma maior concentração nos cursos vinculados às Ciências Biológicas e Profissões de Saúde (37,3\% n 94), seguidos da Filosofia e Ciências Humanas (30,2\% n 76), Ciências Físicas, Matemática e Tecnologia (23\% n 58), Artes (6,7\% n 17) e Letras (2,8\% n 7).

Quando divididas pelas áreas de concentração dos projetos inscritos no Programa Permanecer, 64,5\% (n 156) estão vinculados à Extensão Universitária, 19,4\% (n 47) a Ações Institucionais e 16,1\% (n 39) a Atividades Docentes. A participação efetiva dos estudantes em programas vinculados à extensão universitária cumpre um papel fundamental para a universidade, que é aproximar da comunidade os conhecimentos nela produzidos.

Os bolsistas do Programa Permanecer possuem algumas características em comum: 92,4\% (n 232) dos participantes declararam serem solteiros e $96 \%$ (n 242) não possuem filhos; 92,1\% (n 232) utilizam ônibus como meio de transporte; $96,4 \%$ (n 242) possuem telefone celular; 69\% (n 174) possuem computador pessoal ou familiar; 59,9\% (n 151) possuem acesso pessoal à internet - apesar de 56,8\% (n 130) dos estudantes alegarem somente utilizar os computadores que estão disponíveis na UFBA.

Uma quantidade expressiva de participantes fez curso pré-vestibular por pelo menos um ano $(65,5 \% \mathrm{n} 165)$ e quase metade $(45,6 \%$ n 115) prestou vestibular somente uma vez. Esses dados demonstram 
uma uniformidade da população de estudantes do programa com relação a essas características sociodemográficas.

Embora apresente aspectos comuns, as diferenças se fazem presentes quando são observadas as particularidades étnicas desse grupo de estudantes: 50,2\% (n 126) dos estudantes declararam que são de cor parda, 35,5 \% (n 89) de cor preta, 10\% (n 25) de cor branca, 2,8\% (n 07) declararam-se pertencentes a alguma etnia indígena, e 1,6\% (n 4) de cor amarela.

Mais da metade dos bolsistas (53,9\% n 131) encontra-se cursando entre o quinto e o sétimo semestre; $23,9 \%$ (n 58) entre o oitavo e o décimo, e 20,6\% (n 50) está entre o primeiro e o quarto. Esses dados sinalizam que o programa auxilia, em sua maior parte, estudantes que estão na metade de seus cursos universitários. Apesar de ser um dado positivo, ele representa um contraste com o que a literatura científica indica sobre o fenômeno da permanência. Coulon (2008) e Albuquerque (2008) afirmam que a chegada à universidade é um momento que envolve muitas situações sociais complexas que incidem na decisão do estudante de permanecer ou abandonar seus estudos. Ambos os autores, analisando a questão, afirmam que o abandono é mais frequente nos primeiros meses após o ingresso na universidade ou ainda no primeiro ano. Se levarmos em consideração a literatura consultada, ações específicas voltadas para os recém-chegados devem ser prioridade do programa, o que, seguramente, se choca com uma preferência dos orientadores por alunos mais adiantados em seu percurso acadêmico.

A formação escolar também foi objeto de algumas questões do instrumento. Através delas foi possível constatar que a maioria dos bolsistas do programa terminou o ensino médio entre anos de 2002 e 2006 (71,6\% n 169), sendo que nos anos anteriores, entre 1996 e 2001, o número cai para 22,5\% (n 53), e, entre 1984 e 1995, cai para $4,2 \%$ (n 10). As escolas públicas municipais, estaduais e federais formaram mais de $80 \%$ dos bolsistas do Programa Permanecer, sendo que aproximadamente $50 \%$ delas estão localizadas no interior da Bahia e outros 50\% divididos pela capital Salvador, majoritariamente, e outros 
Estados. O fluxo migratório dos estudantes é intenso e atualmente, $83,1 \%$ (n 211) residem em Salvador, 4,4\% (n 11) vivem em cidades vizinhas da Região Metropolitana de Salvador (RMS), como Camaçari, Lauro de Freitas e Simões Filho, 7,2\% (n 18), em Barreiras e 4,4\% (n 11) em Vitória da Conquista, cidades em que o programa também atua. São poucos os bolsistas que afirmaram fazer uso das Residências Universitárias (13,5\% n 34), distribuídos pela R1 (2\% n 5), R3 (6,3\% n 16) e R5 (5,2\% n 13).

A condição da escola pública em promover transformações sociais tem sido colocada em dúvida desde a implementação dos programas de ações afirmativas. Os críticos afirmam que o Estado brasileiro deveria retomar os investimentos no ensino fundamental e médio, ao invés de investir em ações afirmativas, com o objetivo de realizar um projeto educacional "não racista". Mas os mesmos se esquecem que por anos as administrações federais, estaduais e municipais sucatearam essas escolas com propostas acadêmicas que iam desde processos de aprovação automática até medidas inócuas para minimizar as distorções série/ idade. Com o tempo, após sucessivos ataques, é compreensível que a escola pública tenha perdido parte significativa de sua qualidade, mas isso não significa que a universidade deva ser omissa e negar acesso aos seus estudantes. (MAGGIE; FRY, 2004)

Os pais são apontados como os maiores responsáveis pelo sustento da família dos bolsistas e conjuntamente representaram 78,7\% (n 196 [Pai 39,8\% n 99 e Mãe 39\% n 97]) das respostas. Outros parentes e/ou cônjuges apareceram em minoria, $4,4 \%$ (n 11) e 4\% (n 10) respectivamente, além de outras pessoas - destacadas pelos bolsistas, diferentemente das opções disponíveis no questionário - como avós, irmão, cunhados, padrastos e tios, que, somados, representaram 7,6\% (n 19). O instrumento também solicitou que o participante indicasse a formação educacional do seu pai e de sua mãe. Os pais que nunca frequentaram a escola somam 4,0\% (n 10), os que possuem o primário incompleto e completo representam $33,7 \%$ (n 85 ); ginasial incompleto e completo $13,9 \%$ (n 35 ), colegial incompleto e completo $33,7 \%$ 
(n 85). A porcentagem de pais com formação superior incompleta e completa representa 9,2\% (n 23) e de mães 13,1\% (n 33). Além disso, é expressivo o número de mães que apresentam um nível de formação educacional mais elevado que os pais. Como pode ser visto, as mães que nunca frequentaram a escola somam 3,6\% (n 09), as que possuem o primário incompleto e completo representam 23,8\% (n 60), ginasial incompleto e completo $16,7 \%$ (n 42), colegial incompleto e completo $42,1 \%$ (n 106).

A relação trabalho e escola também foi objeto da investigação. Neste item, 33,7\% (n 84) dos estudantes afirmaram ter trabalhado durante o período escolar, sendo que a maioria ( $89,9 \%$ n 71$)$ enquanto cursavam o ensino médio. Quase metade dos estudantes (46,6\% n 117) afirmou receber, além da bolsa Permanecer, uma ajuda financeira da família e/ou de outras pessoas; 29,9\% (n 75) são responsáveis pelo próprio sustento; $22,7 \%$ (n 57) assumem suas despesas e ainda contribuem para o orçamento familiar e $0,8 \%$ (n 02) são os principais provedores de recursos financeiros da família. A maior parte dos bolsistas $(72,1 \% \mathrm{n} 181)$ declarou ter uma renda familiar entre um e três salários-mínimos, $15,5 \%$ (n 39) somente um salário-mínimo, 10,4\% (n 26) entre três e cinco, e 2\% (n 05) entre cinco e dez.

Nas últimas duas décadas, a sociologia da educação tem se interessado pela relação entre estudantes de origem popular, família e universidade. Para Zago (2006), essa discussão atravessa indicadores como longevidade escolar e as trajetórias ditas excepcionais nos meios populares, o que contrasta com a tendência da sociologia clássica de observar este fenômeno social como resultante de uma equação em que se colocam, de um lado, indicadores econômicos, e de outro, os indicadores sociais ou familiares que participam do fracasso escolar. As pesquisas nessa linha têm mostrado que as ações empreendidas pelos atores sociais contradizem essa responsabilização da família pelo insucesso educacional de seus filhos. Mesmo que os pais tenham poucos anos de escolaridade e enfrentem dificuldades econômicas, as pessoas criam estratégias para terem sucesso na educação. 
A rede social de apoio formada pela família em torno do estudante retrata esta condição, em que os pais contribuem substancialmente para o sustento familiar e ajudam financeiramente na formação superior dos seus filhos. Embora a família auxilie com recursos financeiros, a necessidade de trabalho durante o tempo de estudos na universidade também foi descrita pelos participantes, em 13,5\% (n 34) dos casos; os bolsistas afirmaram que completam sua renda com algum tipo de atividade remunerada, entre elas: aulas de reforço escolar, bicos, costuras, comércio de cosméticos, bijuterias e lanches, trabalhos de babá e ações em eventos artísticos e culturais.

Além da complementação da renda, os bolsistas foram questionados sobre a pretensão de trabalhar durante o curso universitário. Neste item, 50,3\% (n 125) dos estudantes afirmaram que sim, mas apenas em estágio para treinamento, 22,9\% (n 57) têm esta aspiração desde o primeiro ano de curso, mas somente trabalhariam em tempo parcial; $17,3 \%$ (n 43) disseram que sim, mas gostariam de realizar esta atividade somente nos últimos anos de curso; 8,4\% (n 21) não gostariam de trabalhar e 1,2\% (n 03) buscou emprego em tempo integral desde o primeiro ano na universidade.

Estas informações demonstram que a relação trabalho, necessidade de recursos financeiros e formação em educação superior é orientada para a obtenção de uma ocupação que alie o aprendizado que a universidade proporciona à possibilidade de ganhar algum dinheiro. Além de terem o benefício da bolsa, $25,2 \%$ (n 62 ) dos estudantes afirmaram receber algum outro auxílio da Pró-Reitoria de Assistência Estudantil. Entre os mais comuns estão: auxílio para moradia e alimentação, para compra de medicamentos, para fotocópias, bolsa de inglês e isenção de taxas universitárias.

Um aspecto peculiar e contraditório da estratégia de rede de apoio formada pela família apareceu quando os bolsistas foram questionados sobre qual foi a principal influência em relação à escolha do curso superior. Mais de um terço dos participantes $(34,4 \%$ n 86$)$ indicou que ninguém ou nada o influenciou, seguido de respostas como meios de 
comunicação ( $16,8 \%$ n 42), professor (9,2\% n 23), cônjuge, irmão, amigos ou parentes $(8,4 \% \mathrm{n} 21)$, ambiente de trabalho (6,8\% n 17$)$, pai e/ou mãe (3,2\% n 08$)$, orientador educacional da escola (1,2\% n 3$)$ e teste vocacional $(0,8 \% \mathrm{n} 2)$. Se somados, o número de estudantes, que optaram pela resposta pai e/ou mãe e cônjuge, irmão, amigos ou parentes, representa pouco mais de $10 \%$ das respostas válidas, influência relativamente pequena, se comparada ao esforço que a família emprega para conduzir seus filhos à universidade.

Uma quantidade expressiva de estudantes escolheu a opção "outras influências" (19,2\% n 48) e apontou alguns fatores importantes que influenciaram sua escolha, entre eles: a natureza da vida no interior, afinidade e/ou fascínio pessoal com a área, livros ou leitura, ambiente doméstico, amigos conhecedores da área, vocação pessoal, contato diário com a profissão, gostar de matérias específicas do vestibular, participação em projetos de iniciação científica e falta de muitas opções e/ou conhecimento sobre o curso.

Os bolsistas apontaram como principal expectativa em relação ao curso superior a formação profissional para o futuro emprego $(40,1 \%$ n 99), seguida da resposta aumento de conhecimento, cultura geral e consciência crítica $(32,4 \%$ n 80$)$ e da melhoria de situação profissional ou econômica (22,7\% n 56). A resposta "outras expectativas" obteve 4,5\% (n 11), possibilitando o catálogo de outras perspectivas, tais como: aumento de conhecimento associado a uma melhor perspectiva de futuro; aumento de conhecimento, cultura geral, consciência crítica e futuro emprego; contribuição social; exercer atividades artísticas na área de atuação e obter rendimentos com isso; melhoria da vida e não ser "ignorante", visto que os pais não tiveram oportunidade de estudar; aplicar na vida social o que foi permitido conhecer, com devida remuneração e reconhecimento profissional; realização pessoal e profissional; sensação de utilidade, sentido de vida; sonho desde a infância; e nenhuma expectativa.

Em um estudo realizado na Universidade de Coimbra, Estanque e Nunes (2003) destacaram que as expectativas em relação à formação 
superior têm se modificado com a democratização do acesso às universidades. Como o Brasil, Portugal também realizou uma reforma universitária visando propiciar maior acesso e possibilidades de estudo a pessoas de origem popular. Para os autores, as universidades enfrentam hoje uma divisão de classes entre estudantes que têm condição de custear seus estudos e aqueles que precisam de assistência para permanecer. Essa separação gera algumas implicações: os universitários de classe abastada passam a acreditar que os cursos de graduação perderam seu prestígio com a democratização e deslocam suas expectativas para os MBA, mestrados e doutorados, em busca de uma especialização que os diferencie no mercado de trabalho; as expectativas dos estudantes de origem popular, por sua vez, giram em torno das possibilidades de ascenderem a uma posição profissional. O prestígio para eles não está no título em si, mas em corresponder ao investimento de suas famílias, que empregaram parte do orçamento familiar para que eles cursassem a universidade e tivessem possibilidade de conseguir um bom trabalho.

Nesse sentido, os dados do Programa Permanecer sugerem que as expectativas em relação à universidade estão relacionadas à aquisição do conhecimento, ascensão social, possibilidade de entrada no mercado de trabalho. Se somadas, as expectativas de formação profissional para futuro emprego e o aumento da cultura e consciência crítica alcançam mais de $70 \%$ das respostas dos participantes, demonstrando a preocupação dos estudantes em utilizar a universidade como um meio de ascender socialmente. (ESTANQUE; NUNES, 2003)

Também perguntamos sobre como os bolsistas costumam utilizar o recurso da bolsa do Programa Permanecer. Eles foram solicitados a organizar suas respostas pela ordem de importância do gasto. Os elementos centrais são o transporte (n 157 evo 1) $)^{2}$, a alimentação (n 157 evo 3) e material didático de consumo (n 165 evo 4). Essas são três despesas cotidianas na vida de um estudante da UFBA e, neste sentido,

2 A notação evo refere-se à importância dada pelos participantes aos itens do instrumento de pesquisa. As evocações foram organizadas do número 1, as mais importantes, ao número 11, as menos significativas, mas que foram citadas pelos estudantes. 
é possível dizer que o recurso financeiro disponibilizado pelo programa cumpre seu papel de favorecer a permanência na universidade.

Entre outras preocupações dos bolsistas, que não são exatamente cotidianas, mas apresentam um importante significado na vida dessas pessoas, aparecem os gastos com moradia (n 50 evo 2); aquisição de equipamentos, como computador, máquina fotográfica etc. (n 23 evo 5); viagens para fins acadêmicos (n 12 evo 6); saúde (n 71 evo 07); atividades extracurriculares, como cursos, congressos, seminários etc. (n 90 evo 9), e gastos com roupa, sapatos e similares (n 06 evo 11). Nas categorias residuais ou de pouca importância para os estudantes apareceram duas respostas: atividades culturais, esportivas e de lazer (n 04 evo 10) e outras (n 11 evo 8).

Embora estejam cursando a universidade, é preocupante notar que os bolsistas não incluem em seus gastos atividades direcionadas à cultura. Isto pode ocorrer pelo fato das atividades culturais tornaremse secundárias visto que a bolsa é destinada a atender às suas necessidades básicas, pelo valor da bolsa não cobrir todas as necessidades dos estudantes, ou talvez pela pouca relação que os estudantes e a própria universidade fazem entre vida acadêmica e vida cultural. Na categoria outros, os estudantes indicaram mais algumas despesas que fazem parte do seu cotidiano familiar, entre elas: ajuda nas despesas de casa; alimentação para a família; contas domésticas (água, luz e telefone) e medicamento para o pai ou mãe.

Outra questão que surge sobre essa problemática, apontada por Maggie e Fry (2004), refere-se ao fato de que as bolsas funcionam em um sistema de contrapartida, o que acarreta um custo de permanência adicional. Nesse sentido, no caso dos bolsistas do Programa Permanecer, estes devem dedicar vinte horas semanais às atividades do projeto a que estão vinculados, além de dar continuidade ao seu curso e tudo o que isso implica. Neste caso, o custo de permanência adicional é um gasto maior com alimentação e transporte. O modelo do Programa Permanecer necessita ajustar essa equação, ou seja, para que o estudante reduza seus gastos com transporte, alimentação e material didático, 
e usufrua mais de sua vida acadêmica e da experiência cultural possibilitada pela vida universitária. Neste sentido, o programa deve buscar formas de melhorar a qualidade de vida dos estudantes de origem popular, através de um modelo que integre os mais diversos serviços oferecidos pela universidade em uma tentativa de minimizar custos.

\section{CONSIDERAÇÕES FINAIS}

A adoção das políticas de ações afirmativas e de novas formas para a assistência estudantil é vetor de transformação da realidade dos estudantes da UFBA, propiciando novas discussões sobre a inclusão de jovens de origem popular na educação superior. O Programa Permanecer é um primeiro passo na busca de melhoria das condições de permanência dos estudantes. Contudo, os dados apresentados apontam para a necessidade de um maior aprofundamento no estudo dessas populações, trazendo nova compreensão sobre as experiências dos estudantes de origem popular e as principais dificuldades enfrentadas, bem como trazer à tona suas experiências de superação dessas barreiras e entraves ao seu pleno desenvolvimento. Conhecer o impacto dos programas de assistência estudantil e monitorá-los de forma constante é tarefa importante, tanto para a gestão da universidade, quanto para a pesquisa acadêmica.

\section{REFERÊNCIAS}

ALBUQUERQUE, T. Do abandono a permanência no ensino superior. Sísifo-Revista de Ciências da Educação, n. 7, 2008.

ALMEIDA FILHO, N. de. Universidade Nova: Textos críticos e esperançosos. Salvador: EDUFBA; Brasília: Editora UNB, 2007.

BARRETO, A. L. E FILGUEIRA, C. A. L. Origens da universidade brasileira. Química Nova, v. 30, n. 7, p. 1780-1790, 2007.

BEVILAQUA, C. B. Entre o previsível e o contingente: etnografia do processo de decisão sobre uma política de ação afirmativa. Revista de 
Antropologia, São Paulo, USP, v. 48, n. 1, 2005. ISSN 0034-7701

BRASIL. Decreto n. 6096, 24 abr 2007. Institui o Programa de Apoio a Planos de Reestruturação e Expansão das Universidades Federais - Reuni. Diário Oficial da União, Brasília, 25 abr. 2007.

COULON, A. A condição de estudante: a entrada na vida universitária. Salvador: Edufba, 2008.

CUNHA, L. A. A universidade reformada: o golpe de 1964 e a modernização de ensino superior. São Paulo: UNESP, 2007.

DILLMAN, D. A.; SMYTH, J. D.; CHRISTIAM. Internet, mail and mixedmode survey: the tailored design method. Wiley: John Wiley \& Sons, 2007.

ESTANQUE, E.; NUNES, J. A. Dilemas e desafios da universidade: recomposição social e expectativas dos estudantes da Universidade de Coimbra. Revista Crítica de Ciências Sociais, n. 66, p. 5-44, out. 2003.

FÁVERO, M. de L. de A. A universidade no Brasil: das origens à reforma universitária de 1968. Educar, Curitiba, n 25, p. 17-36, 2006.

LIMA, L. C.; AZEVEDO, M. L. N.; CATANI, A. M. O processo de Bolonha, a avaliação da educação superior e algumas considerações sobre a Universidade Nova. Avaliação, Campinas, v. 13, n. 1, p. 7-36, 2008.

MACEDO, A. R. de et al. Educação Superior no Século XXI e a reforma universitária brasileira. Ensaio: aval. Pol. Publ. Educ., Rio de Janeiro, v. 13, n. 47, p. 127-148, 2005.

MAGGIE, Y.; FRY, P. A reserva de vagas para negros nas universidades brasileiras. Estudos Avançados, v. 18, n. 50, 2004.

RIBEIRO, D. A universidade necessária. São Paulo: Paz e Terra S.A., 1978.

SPOSITO, M. P.; CORROCHANO, M. C. A face oculta da transferência de renda para jovens no Brasil. Tempo Social-revista de sociologia da USP, v. 17, n. 2, 2005.

UNIVERSIDADE FEDERAL DA BAHIA. Universidade Nova: Plano de Expansão e reestruturação da arquitetura curricular na Universidade Federal da Bahia. Campinas: Mimeo, 2007. Documento Preliminar.

ZAGO, N. Do acesso a permanência no ensino superior: percurso de estudantes universitários de camadas populares. Revista Brasileira de Educação, v. 11, n. 32, 2006. 


\title{
PRECÁRIO, MAS AMOROSO \\ uma breve discussão sobre a interdição temporária do Espaço Raul Seixas
}

\author{
AMANDA ALVES \\ FÁBIO NIETO LOPEZ \\ LUIS ALBERTO MENEZES CERQUEIRA \\ SUELI BARROS DA RESSUREIÇÃO \\ SONNIA MARIA ROCHA SAMPAIO
}

Acho que o quintal onde a gente brincou é maior do que a cidade. A gente só descobre isso depois de grande. A gente descobre que o tamanho das coisas há que ser medido pela intimidade que temos com as coisas. Há de ser como acontece com o amor. Assim, as pedrinhas do nosso quintal são sempre maiores do que as outras pedras do mundo. Justo pelo motivo da intimidade BARROS, 2010, p. 67

\section{INTRODUÇÃO}

O debate sobre a Universidade tem sido preocupação de diversos autores ${ }^{1}$ ligados à vida dessa instituição. Ela encontra-se, igualmente, na

1 Sobre essas discussões, ver, especialmente, Almeida Filho (2007) e Santos (2005). 
pauta do governo federal via política de ações afirmativas, expansão da capacidade das universidades públicas, retomada dos investimentos e contratação de novos professores, entre outras mudanças recentes que tentam reverter o processo vertiginoso de sucateamento das universidades públicas brasileiras, em ação há algumas décadas. Não se quer dizer, com isso, que as dificuldades da educação superior estão resolvidas, mas, que estamos diante de tentativas sinceras de analisar, em profundidade e de forma mais detida, as questões contemporâneas que envolvem o funcionamento e o papel dessa importante instituição.

Este texto almeja contribuir para a discussão de como esse contexto cambiante repercute na Universidade Federal da Bahia (UFBA), instituição que, inegavelmente, tem participado de forma ativa da proposição de novas políticas e rumos para a universidade e para a educação superior. Precisamente, nos propomos trazer para o debate um caso específico: a interdição do Espaço Raul Seixas, parte das instalações da Faculdade de Filosofia e Ciências Humanas², no campus de São Lázaro. Essa interdição se dá como resultado das intensas intervenções no espaço físico desta Faculdade, que trouxeram reconfigurações também na convivência entre os estudantes, professores e funcionários, e, possivelmente, no processo de afiliação (COULON, 2008) dos novos estudantes matriculados, no ano corrente, em cursos e componentes curriculares dessa unidade da UFBA.

Com esse esforço, acreditamos estar reiterando um dos objetivos do Observatório da Vida Estudantil (OVE) que é o de estar atento às condições institucionais oferecidas para a vida universitária. Embora sendo uma situação transitória, o estudante recém-chegado à UFBA, especialmente em algumas de suas unidades, vai se deparar com um grande canteiro de obras que transfigura a paisagem dos campi e cujos tapumes de proteção impedem o uso de algumas áreas e vias de circulação.

Olhar para essas interdições físicas no espaço, ouvir as críticas e investigar as implicações da nova paisagem que configura uma universi-

2 Ver planta no final do capítulo. 
dade movente, não é se opor ao atual empenho de transformação, mas, sim, colocar em movimento as funções do OVE, de instrumento crítico e analítico do cotidiano universitário e, a partir daí, contribuir para a efetivação de uma universidade que, além de nova, seja também mais acolhedora, mais sensível às necessidades cotidianas de seus usuários, mais aberta ao convívio, mais cuidadosa com a riqueza que os espaços acolhem, e mais reflexiva quanto aos projetos arquitetônicos que implementa.

Para isso, três informantes, que utilizaram o Pátio Raul Seixas e são testemunhas do processo de interdição, foram estimulados a falar livremente sobre o passado e o presente. Um dos entrevistados é estudante, concluinte do curso de Ciências Sociais e integrou o CA de seu curso em plena discussão da destinação futura do pátio pós-reforma; outro entrevistado, vendia livros nesse espaço, há muitos anos atividade que, com a reforma, teve que se mudar de lá e, finalmente, entrevistamos um professor da unidade, assíduo frequentador do Pátio, fechando, assim, um pequeno quadro de diferentes olhares sobre esse espaço que nos dedicamos a estudar.

\section{O ESPAÇO RAUL SEIXAS E SUA INTERDIÇÃO}

A Faculdade de Filosofia e Ciências Humanas (FFCH) foi transferida para São Lázaro, em 1974; desde então, ela comporta, dentre outras, duas edificações principais e as mais antigas: o Casarão e um Pavilhão que, ao longo dos anos, passou a ser chamado pela comunidade, espontaneamente, de Raul Seixas ${ }^{3}$, e cuja construção data dos anos cinquenta, portanto antes da ocupação de São Lázaro pela FFCH, tendo sofrido adaptações para acolher estudantes, professores e funcionários, sempre consideradas insuficientes. Enquanto a administração dos cursos e alguns gabinetes situam-se nas salas do Casarão, o Pavilhão Raul Seixas abrigava, além de salas de aula, o pátio de mesmo nome, que ocupa localização central na edificação.

3 O nome oficial do prédio é Pavilhão Isaías Alves. 
Esse antigo pavilhão de aulas em São Lázaro figura, na história da UFBA, como um dos espaços de convivência mais bem aproveitados da universidade. O seu pátio foi, ao longo de todos esses anos, sede de uma estreita relação de convívio entre estudantes dos diferentes cursos do campus e palco para os mais diversos tipos de manifestações acadêmicas, culturais e políticas: reuniões de grupos de trabalho, assembleias, palestras, festas, exposições, venda de artesanato e de livros novos e usados. A vida relacional, em todos os seus matizes, no Raul Seixas, foi apelidada de patiologia, pelos frequentadores de São Lázaro, não se tendo notícia de há quantas gerações de estudantes esse neologismo foi cunhado. Essa espécie de ciência do cotidiano, a patiologia só podia ser exercida em relação estreita com esse espaço específico e especial e, o melhor, depois das aulas, era ceder ao hábito de se reunir no pátio para, simplesmente conversar, ver e ser visto, saber de notícias de lá e de fora, como se fora um grande/pequeno mercado disponível e cheio de vida.

O pátio Raul Seixas era um ambiente provido de uma estrutura mínima, mas que possibilitava um convívio interpessoal direto entre seus frequentadores, acomodando, de maneira relativamente satisfatória, as demandas da comunidade do Campus de São Lázaro. A estrutura coberta contava com uma cantina, que servia, inclusive, de restaurante, além de diversas mesas com bancos fixos, que proporcionavam a possibilidade de estudar, almoçar, reunir-se ou apenas conversar e descansar. No seu entorno, havia ainda salas destinadas aos Diretórios Acadêmicos, serviços de fotocopiadoras, dois auditórios e a presença de vendedores que utilizavam o espaço para comercializar os mais variados tipos de mercadorias e produtos.

A interdição do Pavilhão de Aulas Raul Seixas ocorreu entre dezembro de 2008 e janeiro de 2009, no período de férias escolares, no qual as atividades, naturalmente, diminuem. Apesar do fechamento, alguns serviços continuariam a funcionar, com autorização da diretoria da FFCH, no corredor que dá acesso a saída lateral; apenas os serviços de Xerox e o clássico livreiro da unidade puderam manter suas atividades no local. 
Ao longo de quase um ano de inatividade do pavilhão, uma intensa discussão se desenvolveu sobre a destinação do prédio após o final da reforma. A conclusão a que se chegou foi a de que a gestão da área, demarcada pelas obras, continuará a ser de inteira responsabilidade da $\mathrm{FFCH}$, tendo-se o entendimento de que isto não fere os princípios gerais do Plano Diretor da UFBA. Este acordo foi legitimado por um Termo de Compromisso assinado no Gabinete do Reitor, após cuidadoso estudo de um documento que discutia a descentralização da gestão desse espaço ${ }^{4}$. O documento - A gestão do pavilhão acadêmico Raul Seixas, redigido pela Congregação da Unidade de São Lázaro - defendia e argumentava acerca da necessidade da gestão continuar nas mãos da $\mathrm{FFCH}$, que deveria participar de forma ativa nos rumos da reforma, opinando inclusive sobre outras necessidades espaciais de interesse da comunidade de São Lázaro, além, evidentemente, da ampliação do número de salas.

Em 14 de dezembro de 2009, com o Termo de Compromisso, a ordem de serviço para o início das obras foi emitida. Neste mesmo termo, ficou acordado que a Reitoria empreenderia todos os esforços para completar as obras do CIEDS 5 , levantando os dois pisos superiores previstos, em virtude do reconhecimento de que as futuras instalações do reformado Pavilhão Raul Seixas não dariam conta das necessidades da unidade.

Tendo sido iniciadas, as obras de reforma ficaram sob a fiscalização da Prefeitura do Campus Universitário e sob execução da DR. Engenharia Limitada, sendo os recursos para seu financiamento da própria UFBA e do REUNI ${ }^{6}$. Segundo o atual diretor da FFCH, João Carlos Salles Pires da Silva, as obras, cujo início foi um pouco retardado, se encontram atrasadas, mas adverte que a responsabilidade pelo atraso é da

4 Segundo proposta inicial, o Pavilhão Raul Seixas deveria ser considerado como um pavilhão de aulas administrado centralmente, como outros que existem nos campi de São Lázaro, Ondina e Canela.

5 Centro Interdisciplinar de Estudos para o Desenvolvimento Social.

6 Programa de Apoio a Planos de Reestruturação e Expansão das Universidades Federais do Ministério da Educação do Brasil. 
empresa executora, pois não houve demora na liberação dos recursos. A estimativa era, portanto, de que o Pavilhão Raul Seixas fosse entregue para utilização, ainda no segundo semestre letivo de 2010.

Quando o pátio foi declarado inativo, no primeiro semestre de 2009, a frequência da comunidade foi, evidentemente, esvaziada. Houve ainda movimentos na tentativa de revitalizar o uso do espaço, a exemplo do projeto Toca em Raul, que promovia música e interações culturais entre os estudantes, mas o andamento dos trabalhos de reforma e sua utilização, como território propício à convivência, deixou de existir.

\section{A VIDA ESTUDANTIL E O PÁTIO}

Pensar sobre um espaço que não mais existe é uma articulação delicada e complexa entre fatos, datas, sua ordem cronológica de acontecimento, e outras dimensões ligadas às experiências de nosso corpo, nossas lembranças sensoriais e afetivas. Ao nos debruçarmos sobre o episódio da interdição do Pátio Raul Seixas, nos encontramos diante, tanto de fatos e diferentes argumentos de ordem objetiva, quanto de suspiros nostálgicos, que falam de dimensões de ordem subjetiva, de vivências significativas que o espaço abrigava, e que parecem ter sido interditadas juntamente com o prédio: Assim que mudou o tipo de estrutura, mudou o tipo de relacionamento.

Entendendo, assim como Coulon, (2008), que a afiliação estudantil está estreitamente vinculada a novas relações com o saber e as regras, mas também com o tempo e o espaço, é necessário ter esses aspectos em perspectiva, ao se estudar o cotidiano universitário. Tudo isso participa do processo vivido pelo estudante, ao ingressar no ensino superior, para que passe da condição de estrangeiro para a de membro competente de uma nova comunidade.

Ser um membro competente desta comunidade exige do estudante conhecimentos que extrapolam a elaboração adequada de trabalhos acadêmicos. Diz respeito, também, às competências cotidianas 
exigidas pela nova cultura que começa a conhecer, implica na apropriação de uma série de códigos que compõe o senso comum, nas práticas e interações aparentemente mais insignificantes. (COULON, 2008) Desta forma, este autor considera que permanecer na universidade o menor tempo possível, como faziam alguns estudantes, segundo a pesquisa que realizou na França, acaba por tornar ainda mais árido esse aprendizado, isolando esse estudante e interrompendo sua imersão na nova cultura. Alain Coulon demonstra, claramente, que ser estudante é um ofício muito mais complexo do que se supõe à primeira vista, pois depende de um aprendizado minucioso e sofisticado da 'linguagem natural do grupo', o que requer tempo e, acrescentamos, convivência.

Avançando na compreensão do processo de afiliação, notamos que esse tempo na universidade requer um espaço que acolha a permanência. Importante sinalizar que a universidade opera como uma "estação" que abriga os trilhos de tempo-espaço individuais por um determinado período. Giddens (1989) traz esse conceito de Hägerstrand (1916$2004)^{7}$ para analisar os percursos individuais que fazemos ao longo de um dia, de um mês, ou de uma vida. Utilizar essa referência nos leva a observar as dificuldades e os tempos de deslocamento, de permanência, ou as restrições de contato que as trilhas individuais enfrentam, assim como as possibilidades de encontros nessas "estações". A permanência na universidade, portanto, corresponderia a oportunidades de intersecção de duas ou mais trilhas de tempo-espaço, oportunizando ao estudante condições de afiliar-se.

O Pátio Raul Seixas, dentro do campus de São Lázaro da UFBA, parecia operar bem essas funções, como aparece na entrevista com o estudante: Quando o pátio ainda estava aberto, o pessoal, apesar de não ter aula, principalmente o pessoal mais velho, usava aquilo como um centro de convivência, sentava pra conversar, pra tomar um café [...]. Neste depoimento, o Pátio Raul Seixas aparece como tendo perdido o que na área da saúde se denomina ambiência, ou seja, uma característica dos

7 Torsten Hägerstrand, geógrafo sueco, responsável por inovações metodológicas e teóricas importantes, inaugurou os estudos sobre geografia temporal e cultural, na Universidade de Lund. 
espaços de encontro entre sujeitos que ultrapassa o aspecto meramente físico e comporta atividades sociais, profissionais e relações interpessoais, apresentando clima acolhedor e saudável. (BRASIL, 2006) Assim, do ponto de vista físico, o Pátio, apesar da precariedade em que já se encontrava, reunia uma disposição espacial e estética agregadora das mais diversas atividades, que proporcionavam troca de experiências, a circulação de notícias e ideias, a formação de opinião sobre temas da atualidade, intra e extrauniversitária, promovendo qualidade nas interações da comunidade acadêmica.

Esta qualidade da convivência na perspectiva de Coulon (2008) parece ser essencial para o processo de afiliação do estudante na Universidade, que passa por três momentos fundamentais até que se dê a internalização de regras e códigos próprios ao ambiente acadêmico, a saber: estranhamento, aprendizagem e afiliação. No pátio, o estudante vivenciava o estranhamento das referências, linguagens, regras de conduta, ao mesmo tempo em que, sendo um lugar de todos, era também acolhido em seus primeiros contatos: de modo precário, mas amoroso, como nos disse o professor entrevistado.

Do ponto de vista psicossocial, a ambiência do Pátio, além de amorosa, comportava-se como palco para a formação da identidade acadêmica do estudante, já que se apresentava como o meeting point da Faculdade de Filosofia e Ciências Humanas. É disso que nos fala o livreiro:

[...] o Raul Seixas, era um espaço de reencontro da galera, né? [...] Fechando aquele espaço ali, ficou muito limitado, perdeu muita coisa. Daqui há, mais ou menos, uns cinco ou seis meses, o espaço deve voltar. Não com a cantina. Então vai perder muito a circulação de gente por aquele espaço ali $[. .$.$] aquele é um espaço muito interessante, onde todo$ mundo se encontrava.

Novamente aqui encontramos para o Pátio a função de estação de encontro entre as pessoas, extrapolando a simples função de circulação, que também está presente. $\mathrm{O}$ interesse pela cantina que ali existia, 
aparece também como preocupação do destino do Pátio, na fala do professor, perguntado a respeito da vida cultural, ali presente, desde o início de sua utilização:

Cultural é mesmo o sentido mais cotidiano de mistura, era uma frequentação, parecia mais um mercado, uma praça pública... como na Bahia, que [tudo] também vira mercado. Porque vendia desde camiseta, livro... além do que, como era ponto de encontro, era o modo mais fácil de dar um recado, de colocar os cartazes, de encontrar as pessoas, [...] de conviviabilidade face a face, coisas que desapareceram. Parece que não vai haver mais cantina quando reinaugurado aquele prédio.

O pátio parecia ocupar a função de principal estação do campus de São Lázaro, um pequeno mercado onde se negociava, não apenas mercadorias, mas um mercado de trocas afetivas, políticas e culturais, como afirma o professor. Espaço propício para a permanência na universidade, para o aprendizado de tornar-se um estudante e, na palavra dos entrevistados, de construção da patiologia:

[...] enquanto mercado de variedades que se prestava, é bem a ágora dos gregos antigos, [...] lugar de encontro, de conversa, de formação de novas amizades, de matar tempo, de uma 'patiologia', que é matar tempo e ficar conversando $[\ldots]$.

Eu acho que esse espaço, que eu arriscaria dizer, é um espaço de formação ética [...]. Ética não se informa, não se ensina, mas se aprende.

Um espaço transformado em ágora, lugar que informa a criação de um ethos, a afirmação de um tipo particular de cultura universitária, na qual "matar o tempo" aparece como condição indispensável, por permitir a permanência no espaço universitário e a criação e realização de atividades para-acadêmicas (COULON, 2008); em oposição ao modelo em que o tempo é utilizado como ausência, como escassez, atualizando o discurso da competitividade, da pressa e da urgência de ter 
sucesso em um exame, em que o espaço é entendido e utilizado como passagem, como corredor para um fim particular, onde pessoas gravitam em torno da sala de aula.

As implicações de interferências no espaço, nas condições de encontros e de convivência, aparecem nesse outro fragmento da entrevista com o professor, que chama a atenção para a convivência como espaço de formação política:

[...] isso também significa despolitização, significa reduzir o espaço de informação da opinião política. Onde é o espaço de formação política? Onde as pessoas podem conversar: 'e aí o que está achando da direção, vai votar em quem?' Vamos fundar um partido clandestino?

Essa opinião expressa o que poderíamos chamar de perda da qualidade de afiliação do estudante. No seu rito de aprendizagem, no segundo momento da afiliação (COULON, 2008), o estudante constrói novas configurações subjetivas e intersubjetivas através da formação de novos vínculos. Desse modo, a Universidade, sendo um lugar onde "todo mundo fala com qualquer um" (COULON, 2008, p, 175), se configura também como um lugar de convivência, que deve proporcionar uma interação entre os estudantes que extrapole as relações em sala de aula como uma das estratégias para a formação psicológica, ética, política e cultural do jovem.

Dayrell (2004, p. 11), nos seus estudos sobre juventude e grupos culturais, destaca que a sociabilidade, que se manifesta através de "grupos de pares, o lazer e a diversão aparecem como elementos constitutivos da singularidade da condição juvenil”, principalmente nas camadas populares. É nesta sociabilidade que os jovens buscam referências individuais e coletivas: "Na sociabilidade, o falar torna-se o próprio fim, o assunto é simplesmente o meio para a viva troca de palavras revelar seu encanto". (DAYRELL, 2004, p. 10)

Seria este o encanto do Pátio Raul Seixas? Estes aspectos da convivência universitária convergem para a natureza democrática da sociabilidade, também apontada por Maturana (2004, p. 31), que considera 
a democracia como forma de convivência que só pode existir entre os adultos se for vivida ao longo do processo de desenvolvimento:

[...] todas as atividades humanas surgiram como conversações (redes de coordenações comportamentais consensuais entrelaçadas com o emocionar). Portanto todo viver humano consiste na convivência em conversações e rede de conversações. Em outras palavras. Digo que o que nos constitui como seres humanos é nossa existência no conversar.

Manter a universidade longe desse processo de esvaziamento de sua função formadora, entendida em sentido amplo e do fomento a uma cultura universitária viva, implica promover uma relação diferente dos estudantes com a instituição e com o conhecimento, estimulando a manutenção de redes de vínculo e solidariedade. As transformações da contemporaneidade que atravessam as rotinas dos indivíduos, em seus aspectos mais sutis, podem implicar o esvaziamento do coletivo, uma despolitização generalizada, na fugacidade dos encontros e no utilitarismo das ações. O professor ajuda a retratar uma época diferente dessa que tratamos, com certa nostalgia:

[...] eu sou de uma época em que a formação se dava em tempo integral, ia morar na cidade, montava uma república e $100 \%$ enturmado dia e noite. Era um modelo de convivência universitária altamente agregada, as pessoas lembram uma das outras, têm sites até hoje, saem até hoje. Isso desapareceu, a universidade como um lugar de amizade, de frequentação, perdeu muito ${ }^{8}$.

8 Sobre esse depoimento, pontuamos que é conhecido o fato de que a memória suaviza o passado para que se possa enfrentar as dificuldades da vida no presente. Não podemos esquecer de que, quando a Faculdade de Filosofia e Ciências Humanas foi transferida, para o que veio a ser o campus de São Lázaro, em 1974, o país encontrava-se, fazia já 10 anos, em pleno regime militar: entidades estudantis fechadas ou em mãos de estudantes que defendiam a ditadura, reuniões e aglomerações proibidas, estudantes e lideranças estudantis perseguidas, algumas presas, torturadas e mortas, outras na clandestinidade. O pátio já existia, mas não era possível utilizá-lo da mesma forma como no período posterior à democratização, que ocorreu em 1985, 21 anos após o golpe militar. 
Estar disperso no espaço universitário tem implicações no sentimento de pertencimento e na formação da identidade do corpo discente, como afirmou o estudante anteriormente. Práticas contemporâneas, que privilegiam a abundância de compromissos, os contatos rápidos ou exclusivamente virtuais, e vínculos cada vez mais frágeis e passageiros, podem interagir com um espaço pouco amigável, promovendo o oposto do que seria desejável, no que diz respeito a esse sentimento de pertencer que deve ser desenvolvido entre os universitários. Diz o estudante: esse prédio novo aqui de São Lázaro, o PASL, é um tipo de estrutura fria, anticonvivialidade, sabe? Uma coisa que você fica limitado a assistir a aula e ir embora. Botaram um jardim ali, mas ninguém usa.

É ainda Bauman (2001), que faz uma observação relevante sobre os espaços, mostrando como estes estão sendo pensados para afastar o infortúnio de se deparar com o estranho e com o imprevisível. O shopping center, por exemplo, seria um 'lugar sem lugar', e funciona para que muitos caminhem lado a lado, mas sem os constrangimentos da negociação e do conflito. Uma comunidade de iguais que não quer ser incomodada, consome, passeia, se entedia, se diverte e se vai. Ida e vinda livre, desimpedida e descompromissada.

Outra constituição arquitetônica característica de nosso tempo e cada vez ganha mais exemplares nos espaços públicos são os "nãolugares”, definidos por Bauman (2001) como destituídos de construção simbólica, de história, de relações, de ambiência, uma vez que seu único destino é o de serem atravessados e deixados para trás o mais rapidamente possível. A partir dessa definição e considerando a finalidade e responsabilidade da universidade com a formação integral das novas gerações é central que ela desenvolva projetos que prevejam espaços que possam ser investidos de sentido pelos usuários através de sua permanência neles. É isso que aconteceu com o pátio: o tempo nele investido, por repetidas levas de usuários, é que o tornou especial e capaz de contar uma história, apesar de toda a sua precariedade. Não era um lugar ideal, mas era, nos termos de Manoel de Barros, o maior lugar do mundo para muitos estudantes que podiam, ali, inventar intimidade com o espaço físico e com seus cúmplices, na condição de estudantes. 
Essa característica dos espaços íntimos não escapou à análise de Santos (2009), em seu livro Pensando o espaço do homem, onde comenta que a emotividade e a presença humana nas coisas inanimadas e na arquitetura foram sacrificadas, e agora resta-nos uma arquitetura desprovida de afetividade. No relato resistente do estudante aparece a tentativa de reverter o processo e de reconstruir intimidade:

[...] a gente tentou revitalizar ele culturalmente, a gente lançou uma campanha 'toca em Raul', que era exatamente essa questão de tocar nele, de fazer ele voltar, e tornar aquele espaço, já que estava inútil, ocioso, tornar ele um espaço onde a gente pudesse se manifestar [...].

Mas, à parte a nostalgia e a "saudade dos velhos tempos", é preciso encontrar saídas, abrir novas portas por onde a mudança possa entrar. Para o livreiro, a transformação passa, necessariamente, pela mobilização dos estudantes: vamos ter que criar outro espaço, né? Mas isso aí depende muito da parte acadêmica, o estudante tem que correr atrás, não se acomodar, deixar tudo na mão da Reitoria.

Mas, a julgar pela opinião do estudante, a desativação do pátio teve consequências para a organização política do segmento já que os CA's de todos os cursos não dispõem de salas individuais para acolher suas atividades, até que seja finalizada a reforma do pavilhão Raul Seixas.

\section{ENTRE NÃO-LUGARES E LUGARES AMOROSOS}

Tencionamos, neste capítulo, trazer algumas reflexões acerca das implicações da interdição física do Pátio Raul Seixas na formação universitária, especialmente dos estudantes matriculados em cursos da $\mathrm{FFCH}$, a partir do olhar de seus usuários. Esse fechamento, para a reforma das instalações do pavilhão de mesmo nome, é apenas uma, entre outras muitas intervenções voltadas para compatibilizar as instalações e a infraestrutura da UFBA com a ampliação do número de vagas e postos de trabalho para novos professores. Entretanto, não é possível ignorar o impacto que as importantes intervenções arquitetônicas atuais im- 
põem ao cotidiano universitário. A reestruturação física dos campi deve ser reconhecida como uma das estratégias fundamentais para alcançar o projeto de uma universidade pública e democrática, mas, para atingir esta meta, torna-se necessário reconhecer, igualmente, a sociabilidade da comunidade acadêmica como um dos aspectos não apenas constituintes, mas centrais para o desenvolvimento de uma cultura universitária. Esse não é um aspecto de importância menor ou que exista a despeito de toda e qualquer condição material. Sua constituição delicada e tecida através de práticas cotidianas necessita de apoio sensível para se constituir.

Através dos olhares de nossos entrevistados vimos que o Pátio Raul Seixas foi, durante muitos anos, o centro de convivência da $\mathrm{FFCH}$, palco das manifestações culturais e políticas, contribuindo para a formação integral do estudante. O seu fechamento foi visto por esses atores como responsável pela substituição da sua atmosfera convivial e calorosa, por outra fria e impessoal, não tendo se constituído nenhum outro espaço substituto, ao longo desse quase um ano em que dura a reforma. São Lázaro teria se tornado "um lugar sem lugar"? (BAUMAN, 2001)

Está claro que a expansão quantitativa da universidade é uma das respostas mais esperadas pela sociedade, especialmente por aqueles que, todos os anos, são impedidos de nela ingressar pela tardia massificação da educação superior no Brasil. Mas essa é apenas uma das faces dessa equação delicada; apresentar respostas contemporâneas para as múltiplas crises da universidade não se limita ao seu crescimento quantitativo. Torna-se necessário também pensá-la como espaço de desenvolvimento e formação integral, considerando as relações vitais que seus usuários estabelecem com os espaços que lhes são destinados.

Se há um esvaziamento dos interesses coletivos, da mobilização política, da construção de vínculos, a universidade deve se ocupar também em viabilizar modelos inovadores de gestão de sua infraestrutura, entendendo que as condições de tempo e de espaço interferem na constituição de uma vida universitária plena de experiências, de aber- 
tura para novas possibilidades, de disponibilidade para a prática ética em ágoras ainda que improvisadas ou precárias.

Não foi a precariedade do espaço Raul Seixas que o tornou especial, mas sim sua capacidade em acolher a permanência das pessoas, constituindo-se em ponto de encontro, de cultura e de trocas. Assim, a sofisticação de um espaço construído, se nele a vida humana não funciona como um disparador de atenção especial e focada, pode constituir-se como mote para a impessoalidade e a dispersão. Nesse sentido, devemos cultivar ideias contra-hegemônicas, no que diz respeito aos opostos complementares espaço/lugar, como aconselha o arquiteto sinoamericano Yi-Fu Tuan (1983, p. 59):

O espaço aberto não tem caminhos trilhados nem sinalização. Não tem padrões estabelecidos que revelem algo, é como uma folha em branco na qual se pode imprimir qualquer significado. $\mathrm{O}$ espaço fechado e humanizado é lugar. Comparado com o espaço, o lugar é um centro calmo de valores estabelecidos. Os seres humanos necessitam de espaço e de lugar. As vidas humanas são um movimento dialético entre refúgio e aventura, dependência e liberdade.

É necessário e central planejar lugares para os encontros, para as pausas e a permanência, permitindo que se criem intimidades com as estruturas, que se conheçam as especificidades de seus cantos; lugares para os tempos mais dilatados, onde a interrupção do movimento automático e veloz seja possível, espaço e tempo para ouvir e ver com mais riqueza de detalhes, e, assim, cultivar a patiologia, amorosamente.

\section{REFERÊNCIAS}

ALMEIDA FILHO, Naomar. Universidade Nova: Textos Críticos e Esperançosos. Salvador, EDUFBA, 2007.

BARROS, Manoel de. Memórias Inventadas: as infâncias de Manoel de Barros. São Paulo: Editora Planeta, 2010.

BAUMAN, Zygmunt. Modernidade Líquida. Rio de Janeiro: Jorge Zahar Ed., 2001. 
BRASIL. Ministério da Saúde. Secretaria de Atenção à Saúde. Núcleo Técnico da Política Nacional de Humanização. Ambiência.2.ed. Brasília, DF, 2006.

COULON, Alain. A condição de estudante: a entrada na vida universitária. Salvador: EDUFBA,2008.

DAYRELL, Juarez. Juventude, Grupos Culturais e Sociabilidade.2004, Belo Horizonte. Disponível em <http://www.fae.ufmg.br/objuventude/textos/ ABA2004.pdf. $>$ Acesso em 20 mar. 2010.

GIDDENS, Anthony. A Constituição da Sociedade. São Paulo: Martins Fontes, 1989.

MATURANA, Humberto R; VERDEN- ZÖLLER, Gerda. Amar e brincar: fundamentos esquecidos do humano. São Paulo: Palas Athena, 2004.

SANTOS, Boaventura de Souza. A Universidade do século XXI: Para uma reforma democrática e emancipatória da Universidade. Educação, Sociedade \& Culturas, 23, p. 137-202. 2005.

SANTOS, Milton. Pensando o Espaço do Homem. São Paulo: Editora da Universidade de São Paulo, 2009.

TUAN, Yi-Fu. Espaço e lugar: a perspectiva da experiência. São Paulo: Difel, 1983.

UNIVERSIDADE FEDERAL DA BAHIA. Faculdade de Filosofia e Ciências Humanas. Resolução 02/2009: A Gestão do Pavilhão Acadêmico Raul Seixas. 2009.

UNIVERSIDADE FEDERAL DA BAHIA. Gabinete do Reitor: Termo de Compromisso. 14 de dezembro de 2009. 


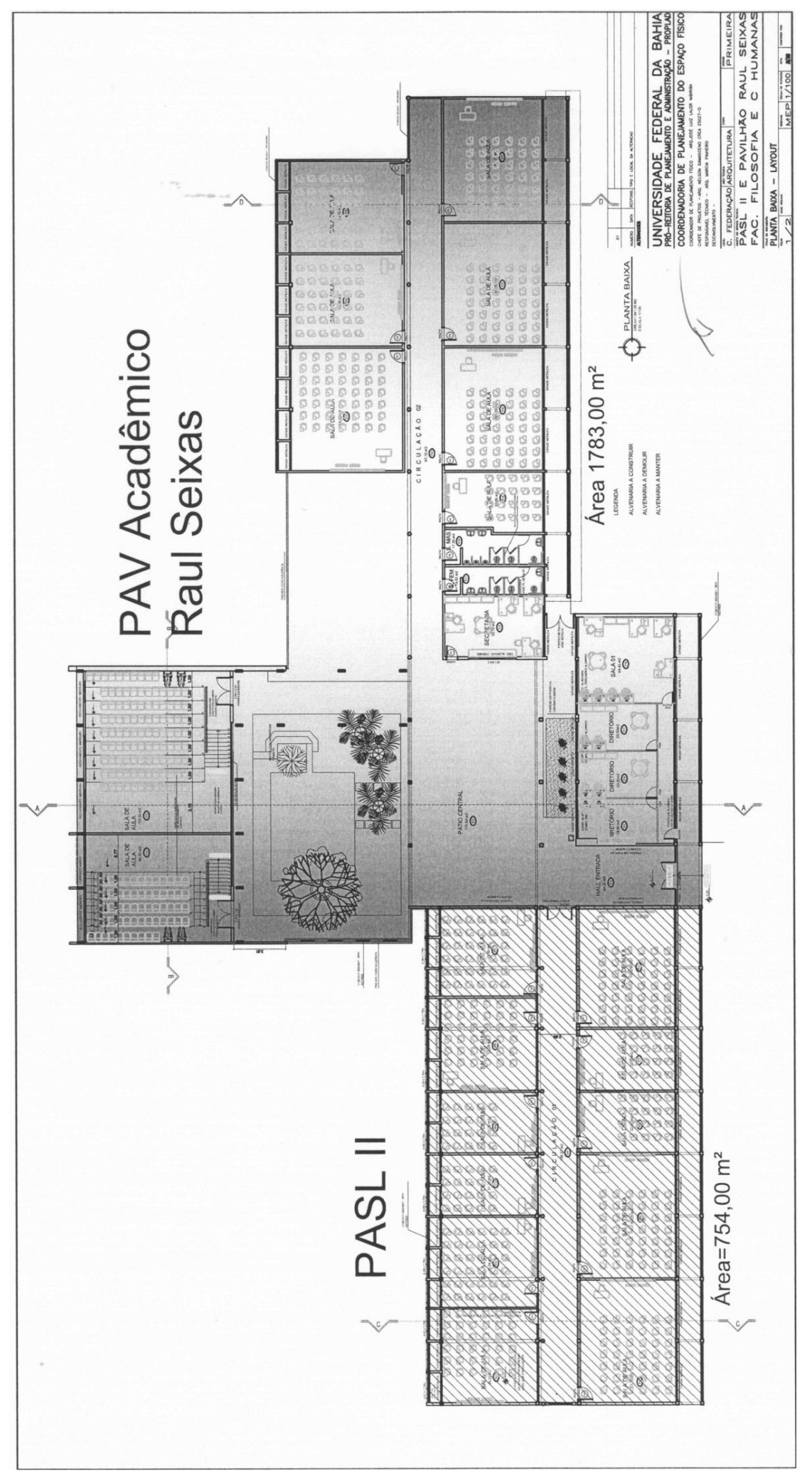

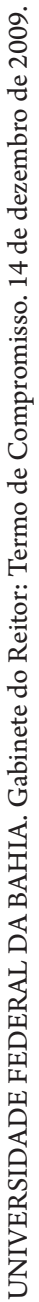




\section{VIDA AFETIVO-AMOROSA \\ E VIDA UNIVERSITÁRIA \\ ambiguidades e contradições}

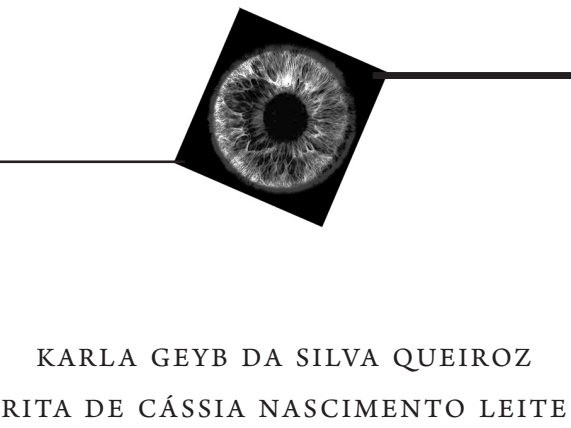

\section{INTRODUÇÃO}

A ampliação do acesso à educação superior tem trazido não só a inclusão de um contingente cada vez maior de jovens ao ensino superior, mas também suscitado debates na comunidade acadêmica e na sociedade em geral. Estes debates têm indicado, principalmente para as ciências da educação, a necessidade de realização de investigações que possibilitem uma maior compreensão dos aspectos que afetam a vida dos jovens que ingressam em universidades.

Mesmo timidamente, já é possível observar que estudos (MARINHO-ARAÚJO, 2009; SAMPAIO, 2009; 2010) começam a extrapolar dimensões clássicas, como a qualidade do ensino, a formação profissional, o mercado de trabalho, voltando-se para outros aspectos, tais como os mecanismos subjacentes à evasão, ao abandono, ao insucesso acadêmico e outros temas relativos à adaptação à vida universitária do 
estudante. Esse movimento, ainda inicial, suscita discussões acerca da importância do item afetividade, que não pode ser negligenciado pela gestão da universidade em favor de um privilégio exclusivo a aspectos cognitivos-racionais, supostos como mais importantes na vida dos estudantes.

Sabemos que a negligência das questões afetivas nos processos de produção do conhecimento se localiza na dicotomia clássica entre razão e emoção e na prevalência dos aspectos racionais sobre os afetivos. Essa dicotomia perpassa a história do pensamento filosófico ocidental, onde a "emoção tem sido descrita como irracional, involuntária, forças do corpo, como 'doenças do espírito, do sentimento'”. (FISCHER; JANSZ, 1995, p. 01) Essa compreensão resulta em uma visão fragmentada do ser humano, destinando às emoções um papel coadjuvante na experiência humana, quando não a de agente desorganizador do comportamento, em geral, sendo caracterizadas pela sua irracionalidade, corporalidade, involuntariedade e animalidade. (FISCHER; JANSZ, 1995)

Assim, as instituições de educação superior, como espaços construídos histórica e culturalmente, primaram pela racionalidade, excluindo delas a vida afetivo-emocional e criando mecanismos para mantê-la sob controle e/ou restrita a momentos e locais apropriados.

Contudo, como Arantes (2002), sinalizamos para a indissociabilidade entre vida afetivo-emocional e processos cognitivos, contestando, assim, a separação entre razão e emoção também no trabalho educativo. Esta compreensão da relevância dos sentimentos e emoções na constituição do ser humano sustenta a elaboração do presente trabalho, cujo objetivo foi refletir sobre a influência da dimensão afetivo-amorosa no desenvolvimento da vida acadêmica de estudantes universitários.

Essa contribuição foi elaborada a partir da utilização da pesquisa etnográfica. Esta abordagem metodológica objetiva conhecer aspectos da realidade, a partir do contato do pesquisador com o campo e de sua imersão no contexto que pretende investigar, enfatizando o processo e

1 Tradução livre de CHAVES, E. S. 
não seu produto final, bem como os significados e sentidos atribuídos à própria realidade pelos sujeitos durante a pesquisa. (ANDRÉ, 1995)

Foram realizadas, no ambiente universitário, entrevistas etnográficas e observação participante com três estudantes do curso de psicologia de uma universidade pública baiana (dois do sexo feminino e um do sexo masculino), com idade entre 20 e 22 anos. Posteriormente, essas entrevistas foram transcritas e analisadas, levando em conta os dados coletados na observação participante e organizados em categorias analíticas. A seguir, apresentamos três dos diferentes aspectos que emergiram dessa análise, ilustrados pelo que nos sugeriram excertos de relatos coletados.

\section{DA RELAÇÃO ENTRE VIDA AFETIVO-AMOROSA E DESEMPENHO ACADÊMICO}

Apesar do discurso da racionalidade rezar a separação entre razão e emoção, entre a afetividade e os processos cognitivos, vários estudiosos (WALLON, 2008; ARANTES, 2002; FREIRE, 1991; DAMÁSIO, 1996) mostram que essas duas dimensões da vida humana se influenciam mutuamente. Até mesmo nas nossas vivências cotidianas, percebemos a importância e a implicação dos acontecimentos afetivos nas outras dimensões da vida humana.

Ao serem questionados sobre sua experiência afetivo-amorosa, depois do ingresso na Universidade, os estudantes entrevistados passaram a relatar episódios carregados de significação emocional. Eles demonstraram ter uma compreensão da relação existente entre vida amorosa e desempenho acadêmico, onde a primeira interfere na segunda:

É, eu tenho uma relação, né, namoro há um ano e atrapalha quando o relacionamento não tá bem, atrapalha muito, muito mesmo, ao mesmo tempo que motiva porque algumas coisas assim, que eu tinha deixado de lado na faculdade, o interesse mesmo foi retomado depois que eu senti um incentivo, sabe? Porque, de certa forma, a pessoa participa da sua vida, tá ali do seu lado pra, te fortalecer, quando você 
fraqueja em alguns momentos, e assim é uma coisa que não [...] de certa forma, não é considerada, é como, por exemplo, você tem algum problema com o relacionamento [...] Acho que é praticamente impossível, eu não consigo fazer nada em nenhum âmbito da minha vida, quando eu não tô bem, assim, com meu relacionamento, sabe, [...] e influencia muito, tanto positivamente, quanto negativamente.

Discorrendo sobre o término de um relacionamento amoroso com outro estudante da mesma instituição de ensino, uma das jovens afirma ter experimentado sentimentos diversos que afetaram diretamente seu desempenho acadêmico. Sentia-se distraída, apática, agoniada, triste, chorava muito, tinha pouca concentração nos estudos, medo, ciúmes e, ao mesmo tempo, vontade de encontrar o ex-namorado. Vindo à universidade apenas para assistir às aulas, pois permanecer neste ambiente, com o risco de encontrá-lo, consistia em um "martírio".

Essa mesma estudante demonstrou receio quanto ao modo como a expressão de seus sentimentos era vista pelos seus colegas:

Pensava na percepção dos outros, de como elas me viam, o que elas comentavam, as pessoas falam muito [...] Acho que os outros percebiam minha tristeza e meus sentimentos. Ficava preocupada em vir nas festas da faculdade e como ele [o ex-namorado] estava ficando com outra menina, achava que as pessoas iam me olhar como coitada.

Essa preocupação com o olhar do outro parece corroborar a compreensão compartilhada de que existem modos adequados de uma pessoa se comportar socialmente que sublinham a racionalidade, a autodeterminação e a responsabilidade. A ideia aqui implícita é que as pessoas que expressam suas emoções estão com algum problema, podendo essa expressão, inclusive, levá-las a uma rejeição do outro. Além disso, corre-se o risco de que sua imagem de pessoa respeitável e "normal" possa ficar comprometida e até mesmo impossível de ser retomada. (FISCHER; JANSZ, 1995)

Observamos, ainda, na fala dos estudantes, uma compreensão de que a interferência da vida amorosa sobre a vida universitária se dá tanto pela sua presença como pela a sua ausência, o que tem o poder de 
influenciar não só o rendimento acadêmico, mas também a participação em outras atividades universitárias:

[...] Então, na questão afetiva e amorosa, eu acho que me motiva, na maioria das vezes, me motiva a fazer as coisas. Aí, quando, eu só namorei uma vez, foi quando eu tive um melhor rendimento, de participação, de discussão, foi quando eu tava namorando. Depois disso eu fiquei meio assim [...] na crise solitária, existencial do amor, me interessando pelas pessoas erradas, que isso é um [...] também é um ponto positivo que me faz ter uma visão crítica em relação ao mundo. Mas o não ter ninguém, ou tá sozinho me desmotiva muito, a não querer participar de quase nada, principalmente na faculdade, da universidade em si. (estudante)

Como nos lembra Rey (2004, p. 81):

As emoções representam, provavelmente, um dos temas menos desenvolvidos na construção do conhecimento psicológico. Elas sempre são tratadas como conseqüências de sistemas diferentes (psicofisiológicos, relacionais, discursivos etc) e não pela sua natureza subjetiva.

Talvez por isso, neste estudo, encontramos igualmente relatos que apontam para a dificuldade em perceber e mesmo dúvida quanto à existência de alguma relação entre o relacionamento amoroso e a vida universitária:

É, eu acho que [...] não sei se eu posso resgatar (uma relação entre ambas) [...] é uma outra dimensão, é que eu acho que tem implicação sim, que é às vezes ter que deixar, assim, pelo fato de não ser um relacionamento assumido, e isso atrapalha porque às vezes eu tenho que deixar algumas atividades da universidade pra tá satisfazendo essa minha necessidade, que é de namorar mesmo. E tem influência direta no rendimento, né, às vezes, sei lá, faltar uma aula ou chegar atrasada porque tem que [...] não posso receber alguma ligação ou ligar da minha própria casa, tenho que fazer isso aqui na universidade, que é o tempo que eu passo fora de casa [...] é mas acho que isso não tem relação direta com a vida acadêmica, acho que não. (estudante) 


\section{UNIVERSIDADE: ESPAÇO DE POSSIBILIDADES OU ENTRAVES PARA VIVÊNCIAS AFETIVO-AMOROSAS?}

A entrada na universidade requer, como nos lembra Coulon (2008), uma grande quantidade de investimento para dar conta de apreender as diferentes dimensões que são exigidas para que um jovem seja considerado um verdadeiro estudante. Isso implica tempo e disponibilidade para realizar todas as atividades acadêmicas o que, na maioria das vezes, acaba por ocupar um amplo espaço da vida do jovem, invadindo, inclusive, o espaço destinado ao lazer, à diversão, ao descanso e à própria vida afetivo-amorosa.

Isso pode resultar não somente em dificuldades para conciliar a universidade e seu relacionamento amoroso, mas também a fazê-lo sentir-se obrigado a escolher entre um e outro, escolha essa na qual a vida universitária pode acabar, frequentemente, saindo vitoriosa:

Então tem toda uma estrutura que você tem que deixar a universidade em primeiro plano, a universidade parece que ela te pede, te solicita $[\ldots]$ a questão dela ser a prioritária ou então você vai assumir o risco de perder, não sei, a consequência mais grave ainda. (estudante)

O que vemos então é o próprio jovem hierarquizando as dimensões que o constituem, deixando sobressair aquelas ditas racionais, mas não sem a presença do conflito e do questionamento:

Abrir mão dos finais de semanas que, assim, é o único tempo disponibilizado acho que pra todo mundo que tem um relacionamento, pra [...] é [...] tá junto assim com pessoa e tal, aí você tem várias atividades assim acumuladas. [...]. É complicado chegar pra pessoa assim e dizer, poxa, a gente não pode se ver porque tô cheia de coisa pra fazer, é como se, de certa forma, fica parecendo que você tá colocando a pessoa em segundo plano e não é. [...]. É ruim porque você acaba nem namorando, nem fazendo a atividade que você tinha de fazer, porque você sabe que a pessoa não ficou bem, não ficou nada bem, aí, vixe, é problemático! (estudante) 
Apesar do questionamento, a possibilidade da vida amorosa apresentar-se como tendo mais relevância que a vida universitária pode levar o jovem a sentimentos de culpa e apreensão:

Às vezes, quando eu me pego, assim, vendo que os problemas do meu relacionamento assim, influenciam na universidade; quando eu vejo que eu deixo a universidade em segundo plano, não por querer, mas porque realmente eu não consigo [...] às vezes eu cheguei a confundir com dependência, de achar que isso era assim uma espécie de dependência do relacionamento amoroso. Mas depois assim, até quando você chegou pra mim e falou que tava com a ideia de fazer esse trabalho e tal, é [...] é realmente aí, é uma dimensão assim que não é considerada, mas que tem muita, muita influência mesmo. É realmente não é dependência, é que é realmente uma instância muito importante, sabe, chega assim a confundir assim, mas já se dissipou a dúvida. (estudante)

\section{ORIENTAÇÃO SEXUAL-AMOROSA E VIDA ACADÊMICA}

Os sentimentos e conflitos resultantes da percepção da priorização da racionalidade no espaço e na vida universitários, com prejuízos para a vida afetivo-amorosa, bem como da sua influência sobre o desempenho acadêmico, mostram um peso adicional para os estudantes cuja orientação sexual é homoafetiva.

Na sua fala, um dos estudantes salienta que, independente da qualidade do relacionamento amoroso vivido, não há possibilidade do seu compartilhamento, tendo em vista o preconceito existente e a falta de abertura observada na instituição para lidar com pessoas que mantêm relacionamentos com o mesmo sexo:

É [...] bom [...] há dificuldade de assumir aqui. Primeiro eu não acho que a universidade seja um espaço aberto pra discussões desse tipo, então é como se nós não existíssemos, de certa forma. Somos sempre os estranhos... Nós gays, enquanto categoria. Então eu acho que como há pouca discussão, há pouca informação e muito preconceito. Então você acaba preferindo esconder mesmo, se proteger, né? Porque aqui eu 
acho que seria muito complicado, uma universidade que eu acho muito [...] hipócrita, entendeu? E por essa questão de não discutir mesmo, não ter esse tipo de discussão e isso não facilita. Se fosse assim, em outra universidade, às vezes eu fico pensando, em que há esse tipo de espaço, eu acho que já teria assumido, sim. A gente acaba ficando meio que escondido. As pessoas questionam, 'você namora?'. Pô, e agora, eu digo que eu namoro ou não digo? As pessoas acham meio estranho [...] Por que não? [questionam], quero estudar primeiro, não quero namorar [...] 'Mas eu namoro também [argumentam os colegas], isso não atrapalha em nada meus estudos.' 'Talvez seja porque você seja hetero [penso]'.

O que o estudante coloca como impossibilidade de compartilhamento da sua vida amorosa e sua orientação sexual pode ser entendido a partir do que nos coloca Louro (2003 apud DINIS, 2008 p. 484):

É comum as escolas tratarem gênero e sexualidade como sendo sinônimos, padronizando um modo único e adequado do que é o masculino e o feminino e possibilitando, de uma única maneira apenas, a forma de viver a sexualidade. Tece-se uma complexa trama normativa que estabelece uma linha de continuidade entre o sexo (macho e fêmea), o gênero (masculino e feminino) e a orientação sexual que se direciona "naturalmente" para o sexo oposto.

Com isso, instala-se aquilo que Dinis (2008) chama de 'diálogo surdo' entre os participantes das instituições educativas, inclusive no ensino superior, que pretendem se ignorar mutuamente. Eventualmente, pode acontecer, inclusive, um pedido explícito de que a homossexualidade não seja revelada: 'Por favor! Não me conte!' Porque uma vez mesmo, em um seminário, eu expus minha sexualidade e houve esse pedido. [É como se me dissesse] 'Tá bom, véi, eu te respeito, mas você não precisa falar isso [...] sobre isso'.

Esse silenciamento acerca da diversidade sexual é percebido pelo estudante na própria forma como o professor lida com a questão:

Até as representações dos próprios professores, né? Os próprios professores na hora que eles vão dar exemplos na sala, 
nos relacionamentos amorosos, e são bem categóricos assim, 'homem e mulher'. E você fica se perguntando assim, você que é gay, então eu não tenho relacionamento?

Como nos lembra Dinis (2008), apesar de tratar da questão da sexualidade, as minorias sexuais e de gênero estão ausentes dos parâmetros curriculares nacionais, bem como encontram resistência, por parte de instituições financiadoras de pesquisa, que se recusam até mesmo a criar uma nova área de conhecimento que englobe os estudos de gênero em educação. Com isso, e na falta de uma referência explícita da diversidade sexual no espaço de educação, resta como recurso ao professor apenas a sua própria compreensão acerca do tema, cabendo-lhe decidir acerca da necessidade ou não da sua inclusão no debate sobre direitos civis, aspecto formador indissociável da função docente.

Esse despreparo do professor para lidar com a diversidade é percebido por um dos estudantes entrevistados que relata uma situação em que ele tenta justificar a sua ausência na aula anterior por acompanhar seu parceiro no hospital:

[...] Agora se você fala que tá com seu namorado [que ficou doente], se você é gay, parece que dá aquele baque assim [...] e a pessoa [o professor] não sabe [o que fazer], não sei. Não sabe por que não sabe mesmo, por inocência ou não sabe por uma discriminação, de não saber lidar com aquilo e acaba deixando pra lá como se você tivesse dando uma desculpa como outra qualquer. E não se considera a questão da relação que você tem com a pessoa, o vínculo que você tem de dizer: poxa, eu tenho um relacionamento amoroso com um homem ou uma mulher, certo. Então ele se sente abalado [o professor], se sente de certa forma, é [...] é [... tendo que assumir a responsabilidade de tá perto.

\section{CONSIDERAÇÕES FINAIS}

Esta abordagem ainda preliminar sobre o relacionamento afetivoamoroso no desenvolvimento acadêmico evidenciou, a partir das informações coletadas, que “[...] necessitamos de modos de conhecer e 
trabalhar que afirmem a complexidade e apontem na direção de detectar tendências, movimentos, direções [...]” (MARASCHIN; TITTONI, 2002, p. 149), e ainda, que necessitamos garantir visibilidade para dimensões da vida humana que foram historicamente negligenciadas pela ciência, mas que são constitutivas e constituintes do ser humano.

O estudo aponta para o fato de que, embora 'invisível' no cotidiano acadêmico, a dimensão afetivo-amorosa configura-se como um elemento importante da experiência do estudante universitário. Assim, sua investigação, e de outros aspectos da vida universitária, pode possibilitar, não somente a construção de programas de apoio ao estudante universitário, que contribuam para sua formação e seu sucesso acadêmico, mas, também, como aponta Vendramini (2004), para o cumprimento do papel científico e social das instituições de educação superior.

Embora esta pesquisa não tivesse originalmente a pretensão de propor políticas educacionais que contemplem a dimensão afetivoamorosa na vida estudantil, ela nos permite refletir sobre as relações que se estabelecem entres os diversos aspectos da vivência dos estudantes, no ambiente acadêmico, como poderes que, na luta por legitimação, podem ou não adquirir visibilidade, mas que, mesmo invisíveis, podem causar efeitos nem sempre reconhecidos imediatamente. (FOUCAULT, 1989)

\section{REFERÊNCIAS}

ANDRÉ, M. E. D. A. Etnografia da prática escolar. São Paulo: Papirus, 1995.

ARANTES, V. A. Afetividade e cognição: rompendo a dicotomia na educação. 2002. Disponível em <http://www.hottopos.com/videtur23/valeria.htm>. Acesso em: 29 nov. 2009

COULON, A. A condição do estudante: a entrada na vida universitária. Salvador, EDUFBA, 2008.

DAMÁSIO, A.R. O erro de Descartes. São Paulo: Companhia das Letras, 1996. 
DINIS, N. F. Educação, relações de gênero e diversidade sexual. Educação e Sociedade, Campinas, v. 29, n. 103, 2008.

FISCHER, A. H.; JANSZ, J. Reconciling emotions with Western personhood. Journal for the Theory of Social Behaviour, [s.1.], n. 25, p. 59-80, 1995. (tradução livre CHAVES, E. S.)

FOUCAULT, M. Microfísica do poder. Rio de Janeiro: Graal, 1989.

FREIRE, J.B. De corpo e Alma: disciplina motricidade. São Paulo: Summus, 1991.

MARINHO-ARAÚJO, C. M. Psicologia Escolar na Educação Superior: novos cenários de Intervenção e Pesquisa. In: . Psicologia escolar: novos Cenários e Contextos de Pesquisa, Formação e Prática. Campinas, SP: Editora Alínea, 2009. p. 155-202

MARASCHIN, C.; TITTONI, J. Cotidiano e configuração de espaços de aprendizagem. Educar, Curitiba, n. 19, p. 147-157, 2002.

REY, F.G. Personalidade, saúde e modo de vida. São Paulo: Pioneira Thompson Learning, 2004.

SAMPAIO, S.M.R. Explorando Possibilidades. O trabalho do psicólogo na educação superior. In: MARINHO-ARAÚJO, C.M. Psicologia escolar: novos Cenários e Contextos de Pesquisa, Formação e Prática. Campinas, SP: Editora Alínea, p. 155-202, 2009.

. Psicologia na Educação Superior: ausências e percalços. Em Aberto, Brasília, v.23, n. 83, p. 95-105, mar. 2010.

VENDRAMINI, C.M.M. et al. Construção e validação de uma escala sobre avaliação da vida acadêmica (EAVA). Estudos de Psicologia, v. 9 n. 2, p.259268, 2004. Disponível em <http://www.scielo.br/pdf/epsic/v9n2/a07v9n2. pdf $>$. Acesso em 29 nov. 2009.

WALLON, H. Do ato ao pensamento: textos fundantes de educação. Petrópolis: Vozes, 2008. 


\title{
MÃES E UNIVERSITÁRIAS \\ transitando para a vida adulta
}

\author{
SÔNIA MARIA ROCHA SAMPAIO
}

ANA MARIA DE OLIVEIRA URPIA

\section{APRESENTAÇÃO}

Possivelmente, impulsionadas pelas recentes discussões sobre cotas e políticas de ações afirmativas, tem surgido nos últimos anos uma variedade de pesquisas focando questões relativas ao acesso e permanência dos jovens de origem popular no contexto das universidades públicas. Nesse cenário, pesquisadoras como Sampaio (2008) sublinham que pensar em permanência exige compreensão simultânea de que a entrada na vida universitária coincide com uma série de processos relativos à transição do jovem para a vida adulta. Processos estes que não podem ficar ao largo das investigações sobre juventude e universidade. Preocupada com os estudantes de origem popular, a pesquisadora afirma não pretender focar sua atenção apenas sobre essa população, considerando importante que outros cortes sejam feitos, contemplando gênero, etnia, grupo de idade, pessoas com deficiências e segmentos que combinam 
a vida universitária com outros elementos característicos do ciclo vital, como trabalho ou maternidade/paternidade.

Esta perspectiva nos coloca diante da necessidade de ver o grupo social a que chamamos jovens universitários, como propõe Pais (1990), ao referir-se à juventude, no mínimo, a partir de dois eixos semânticos de igual importância: primeiro, como aparente unidade (quando referida a uma fase da vida), segundo, como diversidade (quando estão em jogo diferentes atributos sociais que fazem distinguir uns jovens dos outros). Assim, quando nos referimos aos jovens universitários, somos capazes de distinguir juventudes, na medida em que nos vemos frente a diferentes realidades: jovens universitários(as) em tempo integral, jovens universitários(as)-trabalhadores(as), jovens universitários(as)-solteiros(as), jovens universitários(as)-casados(as), jovens universitários(as)-com filhos(as), dentre outros, numa perspectiva bem diferente daquela juventude - no singular, e sem distinção de gênero ou condição de vida - referida enquanto grupo social em determinada faixa etária e fase da vida.

Sob este ponto de vista, Mães e Universitárias: transitando para a vida adulta, com base nos resultados da pesquisa de mestrado em Psicologia, denominada Tornar-se mãe no contexto acadêmico: narrativas de um self participante, apresenta neste capítulo a experiência das jovens universitárias que, no percurso da formação superior, tornam-se mães, sendo confrontadas com a desafiadora tarefa de conciliar maternidade e vida acadêmica. As narrativas aqui apresentadas mostram a realidade de jovens mães-universitárias que, a despeito das incontáveis dificuldades, permanecem lutando pela conclusão e sucesso de seus estudos, num contexto marcado por uma histórica tradição androcêntrica, que não cessa de colocar barreiras para a mulher que pretende avançar na carreira acadêmica. (WOLF-WENDEL; WARD, 2005)

Como aponta a literatura nacional e internacional sobre a experiência da parentalidade (tornar-se pai ou mãe), no contexto das universidades, a chegada de um(a) filho(a) na vida de mulheres que fazem carreira no contexto acadêmico traz uma série de dificuldades, 
especialmente aquelas relacionadas ao preconceito de gênero e ao processo de conciliação entre maternidade e vida acadêmica, o que já não ocorre entre os homens, que tendem a ascender mais rapidamente, quando "casados e com filhos". (MANSON; GOULDEN, 2002; AQUINO, 2006)

Estas pesquisas, no entanto, exatamente por focarem a experiência de mulheres e homens adultos, docentes e pesquisadores de universidades, não têm respondido à seguinte pergunta: o que acontece quando mulheres, ainda na condição de jovens universitárias e dependentes de suas famílias, tornam-se mães no contexto acadêmico? Questão que pretendemos abordar neste capítulo e que consideramos cada vez mais incontornável, haja vista o prolongamento da juventude e o surgimento de experiências juvenis envolvendo a vivência de eventos simultâneos de transição para a vida adulta, como a passagem para o status de universitário e o processo de transição para a maternidade. É importante lembrar que estes eventos fazem parte do processo maior de transição para a vida adulta que, tradicionalmente, se iniciava com a conclusão dos estudos [em geral ensino médio e não ensino superior], prosseguia com a entrada no mercado de trabalho, o casamento e a constituição de um novo domicílio, culminando, em geral, de modo linear, com a chegada dos filhos. (CAMARANO, 2006)

Contudo, em função das transformações por que passa a sociedade contemporânea, pesquisadoras como Camarano (2004) sugerem que os processos de transição para a vida adulta são hoje marcados por descontinuidades e rupturas, reversibilidade e simultaneidade de eventos de transição, não cabendo mais pensá-los através da lógica linear de sucessão passo a passo. Consideram ainda que são de duas ordens as mudanças que vêm sendo observadas nestes processos: a primeira delas, cujo caráter é de ordem pública, envolve o aumento da escolarização (inclusive com a exigência de uma formação universitária), bem como as dificuldades de inserção do jovem no mercado de trabalho; a segunda, de ordem privada, relaciona-se à desvinculação entre atividade sexual e união conjugal, o que aponta para uma flexibilização 
dos relacionamentos afetivos e, também, para a organização de novos arranjos e dinâmicas familiares.

Nesse curioso contexto de mudanças nos processos de transição para a vida adulta de jovens da atual geração, nos interessa destacar, particularmente, as problematizações decorrentes do distanciamento ou descompasso que se observa hoje, entre o exercício da sexualidade na juventude, a "antecipação da maternidade" e a conquista da independência ou entrada na vida adulta, que vem sendo postergada, em função não apenas das dificuldades de se entrar no mercado de trabalho, como da necessidade de seguir uma formação universitária. Não podemos deixar de ver que, embora, na atualidade, as expectativas sociais preconizem para as jovens uma escolarização prolongada e um controle contraceptivo adequado e seguro (PERES; HEILBORN, 2006), não é incomum que jovens, no percurso da formação superior, surpreendidas por uma gravidez imprevista ${ }^{1}$, optem pela prática do aborto ou experienciem os inúmeros desafios de tentar conciliar maternidade e vida acadêmica, quando decidem pelo prosseguimento de uma gravidez não-planejada, como sinaliza a pesquisa de mestrado que ora apresentamos neste capítulo. Segundo dados do Censo 2000, realizado pelo IBGE (2000), 8,81\% das mulheres cursando o ensino superior, com idade entre 19 e 29 anos têm filhos na faixa etária de 0 a 4 anos. Significa dizer, portanto, que quase $10 \%$ das mulheres universitárias brasileiras nesta faixa, são mães de crianças pequenas, e podem vir a demandar políticas públicas que lhes permitam permanecer no ambiente acadêmico e concluir seus estudos com melhores chances de entrar no mundo do trabalho. Questão que deve ser motivo de discussão e investimento por parte das universidades que hoje também passam por mudanças, redefinindo o alcance da assistência estudantil e necessitando inovar as políticas de ações afirmativas.

1 Expressão usada pelas pesquisadoras Peres e Heilborn (2006) para referir-se à gravidez não-planejada. 


\section{ASPECTOS TEÓRICOS E METODOLÓGICOS}

\section{a. A escrita autobiográfica em etnografia}

A escolha pela abordagem da Etnografia Autobiográfica deveu-se ao fato de considerarmos, tal como observa Coffey (1999), que colocar a prática autobiográfica ao lado da representação etnográfica traz um maior engajamento do ator social individual $-o(a)$ pesquisador(a). Não obstante, neste relato de pesquisa, seja dado maior destaque às biografias de três das estudantes-mães entrevistadas ao longo da investigação, e não exatamente às experiências da pesquisadora, como observadora-participante do contexto da pesquisa - a Creche-UFBA. O importante a destacar aqui é que partimos do reconhecimento de que "nossas análises dos outros são o resultado de encontros interacionais e processos em que estamos pessoalmente envolvidos". (COFFEY, 1999, p. 115, grifo do autor). A reconstrução do trabalho de campo é, nesse sentido, um evento intertextual, pois relembrar é fundir notas de campo, memórias, relatos transcritos e, em alguma medida, biografia pessoal. A tarefa do(a) pesquisador(a), nesse caso, é de natureza, não apenas descritiva, como também interpretativa, o que requer uma tentativa constante de maximizar a possibilidade de apresentar o contexto e as biografias que o compõem, da forma mais próxima da ótica e da subjetividade das pessoas em situação.

\section{b. Marco teórico}

Por último, e antes de iniciarmos a apresentação dos resultados da pesquisa, é necessário destacar que as análises foram desenvolvidas com base na interlocução entre a Psicologia Cultural do Desenvolvimento e a Abordagem do Self Dialógico, que privilegiam o diálogo pessoa-cultura e a construção de significados nos processos de desenvolvimento. Para estas abordagens, a cultura é exemplificada através dos diferentes processos pelos quais as pessoas se relacionam com seus mundos. Pessoa e ambiente são considerados, nesse contexto, enquanto inclusivamente separados, de modo que pessoa e mundo social constituem-se 
mutuamente (VALSINER, 2007), o que significa dizer que a cultura é inclusiva do self, e este, inclusivo da cultura. A ideia de cultura, assim descrita, nos remete à visão de Wang e Brockmeier (2002). Para esses autores:

Cultura é [...] um sistema e um processo de mediação simbólica - um modo de configuração no qual a linguagem é fundamental. Manifestando-se nas instituições sociais tão bem quanto nas ações, pensamentos, emoções, crenças e valores morais dos indivíduos, [...]. (WANG; BROCKMEIR, 2002, p. 46)

Segundo Valsiner (2007), "é o processo dual de internalização e externalização que garante a falta de isomorfismo entre as culturas coletiva e pessoal, tornando cada indivíduo uma pessoa única, ainda que esteja apoiado nas bases de sua cultura coletiva”. Embora as mensagens possam ser similares para diferentes indivíduos, por exemplo, ainda que todas as mulheres de nossa sociedade recebam a mensagem do mito do amor materno, cada uma delas será afetada de modo diferente por ela, e construirá uma rede de significados pessoais acerca daquele dado culturalmente compartilhado. A multiplicidade das mensagens comunicativas, ou seja, a "cultura coletiva" constituirá, então, como sugere Valsiner (2007), o "input” heterogêneo para a construção de um self, que se configura, assim, como dialógico.

O self dialógico deve ser entendido como social, mas não no sentido de um indivíduo independente que entra em interação com os outros sociais, do lado de fora. Nesse self-social, outras vozes ocupam posições no "espaço interno" do self multivocalizado. Essa teoria é baseada na construção de significado do self na relação com os outros. A construção de significados torna possível para o self a criação de diferentes e distanciadas posições do eu no tempo e no espaço. Desse modo, o eu pode ser mãe e universitária ao mesmo tempo, mas ainda pode assumir, como mãe, a posição de uma sogra, graças ao diálogo que se estabelece entre o eu e o outro, ambos fazendo parte do self, que 
é dialógico. (VALSINER, 2003) O self dialógico é baseado na suposição de que existem múltiplas posições do eu que podem ser ocupadas pela mesma pessoa. $\mathrm{O}$ eu em uma posição pode concordar, discordar, contradizer, questionar e mesmo desafiar o eu em outra posição, pois as diferentes posições no self dialógico podem ter suas próprias visões, desejos, motivos, sentimentos e memórias.

Mas o movimento das posições e suas mútuas relações são dependentes de mudanças culturais, e há, nesse sentido, uma relativa autonomia da pessoa. As vozes coletivas que dialogam nesse self são governadas por oposições polares, próprias do sistema de 'dicotomias sociais', expressos, por exemplo, nas relações entre homens e mulheres ou adultos e crianças. Porque estas oposições são carregadas com diferenças de poder, as vozes de alguns grupos têm mais oportunidade de serem ouvidas que outras. Como resultado, pessoas não constroem significados no espaço livre e com oportunidades iguais para expressar suas visões. "Ao contrário, os significados são organizados e coloridos por posições sociais representadas por coletividades às quais eles pertencem”. (HERMANS, 2001, p. 263) Isto porque, as vozes coletivas não estão somente fora, mas também em um self particular, porém multivocal.

\section{ANÁLISE E DISCUSSÃO: AS NARRATIVAS DAS MÃES-UNIVERSITÁRIAS}

Nesta seção, buscaremos descrever como se deu o complexo processo de transição para a maternidade de três jovens universitárias entrevistadas ao longo da pesquisa, desde já atentos para o fato de que estamos diante de experiências de transição não lineares, que não seguem a lógica de sucessão passo a passo. É importante observar que, ainda nos primeiros passos do processo de transição para a vida adulta, simbolizados aqui pela entrada na universidade, estas jovens vivenciam, simultaneamente, a transição para a maternidade, em tese, o último passo neste mesmo processo, se considerarmos o modelo tradicional de tran- 
sição. A análise da experiência dessas jovens coloca em destaque três importantes momentos ou tempos ${ }^{2}$ da experiência de tornar-se mãe no percurso da formação superior, marcados por um processo intenso de construção de significados e relações dialógicas, a fim de permitir o prosseguimento do curso de desenvolvimento. Entretanto, em função de nosso objetivo neste capítulo, focalizaremos apenas o primeiro e o terceiro tempos desta experiência, que denominamos, respectivamente, de tempo da crise e da incerteza e tempo do enfrentamento e da projeção. O primeiro tempo, como será possível observar, tem a descoberta da gravidez como um marco, e diz respeito, portanto, ao confronto das universitárias com uma gravidez não prevista no percurso da formação superior. O segundo tempo, por sua vez, tem como marco o nascimento dos filhos(as) das universitárias entrevistadas, e corresponde, mais particularmente, à exigência cotidiana de conciliação entre as demandas da maternagem e as demandas da vida acadêmica, em alguns casos experienciada ao longo do processo de afiliação à universidade.

\section{a. A gravidez imprevista no percurso da formação superior}

Como destaca Romanelli (1995), entre as camadas médias da sociedade brasileira há, por parte das famílias, um grande empenho para que os filhos tenham acesso ao ensino superior. Como grupo, a unidade doméstica, mais particularmente o marido e a esposa, elaboram aspirações que são organizadas em torno de um projeto familiar. Afinal, "a escolha do curso é resultado de um processo longo de avaliação das aspirações do candidato, das profissões e do mercado de trabalho, que é lentamente elaborado na relação com a família”. (ROMANELLI, 1995, p. 23) Esse projeto é direcionado para alcançar metas individuais/coletivas, cujos objetivos são: a promoção da mobilidade social do grupo doméstico, e de seus componentes. Quando o projeto familiar compreende a formação acadêmica de um de seus membros e nele os

2 Ver os três tempos do processo de tornar-se mãe no contexto acadêmico, descritos na dissertação de mestrado aqui referida, inspirados nos três tempos do tornar-se universitário, sugeridos por Coulon (2008). 
pais colocam muito de sua energia - o que envolve sacrifícios - e esse componente altera esse projeto com opções que desagradam ao grupo familiar, surgem os conflitos. Foi o que ocorreu com Sara ${ }^{3}$ : Meu pai ficou o tempo todo da minha gravidez sem falar comigo porque ficou muito decepcionado. Meus dois irmãos, o mais velho, ele não olhava no meu olho, baixava a cabeça quando me via. Foi bem difícil assim pra mim.

É importante destacar que Sara, assim como outras jovens que contam com a creche da universidade como suporte social durante o percurso da formação acadêmica, tinha origem interiorana, onde sua família ainda residia. A sua entrada na universidade foi cercada de muitas expectativas associadas aos resultados da formação acadêmica. Sara cursava biologia quando engravidou de Nina, mas este curso era apenas um degrau para uma aspiração maior: o curso de medicina, para o qual ela desejava prestar vestibular assim que concluísse a primeira graduação: Foi bem difícil assim, para mim. E também a faculdade, né? Biologia, eu curso biologia, mas o que eu quero mesmo é Medicina. Então eu sempre quis terminar logo biologia para poder entrar em medicina.

Assim, como sugere sua narrativa, a descoberta da gravidez foi um verdadeiro "balde de água fria" em seus sonhos e de sua família, que nela investia suas esperanças de ver uma filha formada em biologia e medicina.

Nota-se, na dimensão psicocorporal, que a experiência toma diferentes significados, até mesmo opostos, para expressar os conflitos que vivem as jovens, ao se depararem com uma gravidez não prevista. Assim, elas dizem que viveram um misto de emoções, ou que sentiram, ao descobrir a gravidez, medo e felicidade, ou que, durante a gestação, se sentiam "no físico feliz, mas, no psicológico, abaladas" e que choravam muito. As palavras - confusa, medo, felicidade - são marcantes nesse primeiro tempo, revelando os significados relacionados à nova condição e futura posição: a de estudante-mãe. Assim, quando perguntamos

3 Os nomes das universitárias usados ao longo deste capítulo são fictícios, e têm o propósito de preservar a identidade das jovens participantes da pesquisa. 
sobre como se sentiu ao descobrir a gravidez, Marta, a mais jovem das entrevistadas, comenta:

Eu fiquei nervosa, na verdade assim [...] Eu tinha uma suspeita e também queria, era assim um desejo meio implícito, mas nunca desejei e não esperava. Assim, é complicado entender, se fosse eu ficaria feliz, mas se não tivesse eu também ficaria feliz porque eu tinha muita coisa pra fazer também [...] Na hora eu fiquei branca, gelada, meu namorado (na época namorado) estava na hora também muito nervoso, nervoso e feliz, estava aquele misto assim de medo e felicidade. (Marta, 21 anos)

De acordo com o relato de Liana, a jovem que apresentaremos a seguir, a maioria das universitárias que tinha seus filhos na creche da universidade, na ocasião da entrevista, não haviam planejado a experiência da gravidez, o que se verifica no relato das outras jovens, quando destacam: nunca desejei e não esperava, eu não queria ser mãe. Embora não seja possível confirmar a hipótese formulada por Liana, porque entrevistamos um número reduzido de estudantes-mães, os relatos das quatro entrevistadas apontam para o fato de que estas foram "pegas de surpresa" com a notícia da gravidez, em geral resultante de algum "descuido", "desejo implícito”, como argumenta Marta, ou da pouca familiaridade com o uso dos contraceptivos. Não obstante estes resultados tenham uma abrangência reduzida, não havendo pretensão de generalizações, eles corroboram com outras pesquisas, como a investigação acerca da gravidez na adolescência entre jovens das camadas médias do Rio de Janeiro. (BRANDÃO, 2003) Nesta, a pesquisadora Brandão (2003) observa, à semelhança de Heilborn, Cabral e Bozon (2006), que a sexualidade é um dos principais domínios que incitam o jovem a exercitar a autonomia, envolvendo não apenas o aprendizado dos modos de estabelecer um relacionamento afetivo-sexual e as regras de aproximação e negociação a dois, como a interiorização processual das normas de contracepção:

Também tem o fato de que a maioria, 100\% das meninas aqui [que têm filhos na creche da universidade] não tive- 
ram filhos porque quiseram, na hora que quiseram. Então foi um $[. .$.$] não foi erro, foi descuido, às vezes foi um susto$ que tomou, né? E no meu caso foi a mesma coisa, eu não estava esperando ter filho. Na verdade foi assim, eu tomava um remédio e eu parei para tomar injeção, o mês em que eu parei foi o mês em que eu engravidei. Então foi assim, aí tem aquela coisa, universitária... eu engravidei com 4 semestres, então eu estava na época de curtir, 20 anos. (Liana, 23 anos)

As estudantes consideram-se novas para viver a experiência da maternidade, e referem-se ao fato de não terem planejado a vinda do(a) filho(a) como um elemento complicador, com implicações diversas, a depender das inúmeras variáveis situacionais. Assim, a notícia da gravidez e todo o seu transcurso são vividos de forma ambivalente pelas entrevistadas, que ora aceitam a gravidez, ora questionam a sua validade mediante os muitos desafios que já se apresentam antes mesmo do nascimento de seus bebês. A situação de Liana, por exemplo, complicou-se desde os primeiros meses, após descobrir que seria mãe. Sua gravidez foi de risco, e, aos três meses de gestação, já não podia mais sair da cama: Eu não podia levantar pra fazer 'xixi', minha placenta estava descolada, eu tive descolamento de placenta, então eu tomava banho na cama, minha mãe me dava banho na cama.

Não obstante o companheiro de Liana tenha feito uma verdadeira "peregrinação", encaminhando relatórios médicos ao SMURB, seu processo não foi deferido, e ela precisou trancar um ano de faculdade. Nesse período, Liana passou por momentos difíceis: Então, isso me deixou bem triste [...] A primeira vez que eu tranquei a faculdade eu fiquei em depressão.

Embora não se deva pensar que a gravidez torna a mulher alguém incapaz de exercer suas atividades cotidianas, haja vista que muitas mulheres trabalham e estudam até pouco tempo antes do nascimento de seus bebês, podemos afirmar que ela - a gravidez - é o primeiro passo de um processo de transição, que pode tomar diferentes configurações na vida de cada jovem mulher. A questão, como afirma Zittoun (2003, 
p. 417), é que "transições [tais como a experiência de tornar-se mãe] envolvem sequências de problema/ruptura, o engajamento do labor representacional conduzindo para alguma resolução/resultado, de tal forma que a ação possa continuar”. Para esta autora, essas rupturas podem ocorrer, tanto no mundo interior da pessoa como nos relacionamentos interpessoais, e envolvem um processo complexo de construção de novos significados a fim de alcançar uma nova estabilidade e seguir em seu percurso desenvolvimental:

Foi horrível. Horrível. Pra mim foi horrível porque eu não queria ser mãe. Nunca quis ser mãe. E eu não estava com o pai dela. [...] Eu tinha uma vida ativa. Eu tinha dois estágios, eu trabalhava de domingo a domingo, eu saía muito com meus amigos, eu pegava muitas disciplinas. E aí, depois de Nina, depois que eu descobri que estava grávida, eu parei tudo isso. Larguei o estágio, não consegui fazer nada durante a gravidez. Eu fiquei feliz por estar assim. No físico, eu estava feliz com meu físico. Eu fiquei, me achava linda. Mas meu psicológico estava muito abalado. Eu chorava muito. (Sara, 23 anos)

No caso de Sara, não foi exatamente a nova condição física que a impediu de continuar suas atividades, antes, a sua condição psicológica. Na dimensão que chamamos aqui de psicocorporal, ela se debatia, possivelmente à procura de uma resolução para aquilo que lhe parecia um problema de difícil solução naquele momento. Preocupava-se, tanto com as expectativas familiares, quanto com seu futuro e formação, com suas próprias expectativas formativas, pressentimentos e possibilidades futuras. Afinal, no seu caso, havia um agravante: sua família não havia aprovado o seu relacionamento com aquele que, a esta altura, já era seu ex-namorado, mas também futuro pai de sua filha: Minha família não aceitava ele lá em casa. Ninguém falava com ele, o tratava muito mal e vice-versa. Eu briguei, fiquei brigada com minha familia durante todo o tempo de namoro. (Sara, 23 anos)

Assim, ela se refere à experiência da gravidez como um momento vivido com sofrimento, implicando em perdas ocupacionais, relacionais, e também na trajetória estudantil. 
Neste primeiro tempo da experiência de tornar-se mãe no contexto da vida acadêmica, vale sublinhar, as jovens ainda não têm a dimensão do que significa viver, simultaneamente, maternidade e vida acadêmica, daí as dúvidas e incertezas, bem como a ambiguidade de sentimentos. Contudo, em função das diferentes prescrições de gênero da nossa cultura, pressentem as responsabilidades futuras que, em geral, ainda recaem sobre as mulheres, levando-as a recear as mudanças que experimentarão com o nascimento da criança que se anuncia.

\section{b. Simultaneamente, mães e universitárias: a exigência da conciliação}

Como sugere Coulon (2008), a entrada dos estudantes na universidade envolve uma passagem, ou seja, um processo de transição para um novo status: universitário(a). Significa dizer que esta posição não é alcançada de uma só vez, ao contrário, deve ser conquistada mediante uma série de aprendizados, assim como do enfrentamento de situações institucionais e pessoais que se configuram diferentes para cada estudante, embora guardem algumas semelhanças. Essa passagem para a condição de universitário é descrita pelo autor como acontecendo em torno de três tempos: o tempo do estranhamento, o tempo da aprendizagem e, por último, o tempo da afiliação (COULON, 2008, grifo do autor). A passagem para o status de afiliado, portanto, para além da entrada na universidade, ocorre a partir do aprendizado do ofício de estudante, o que significa dizer, aprender os inúmeros códigos e modos de funcionamento da instituição-universidade, de modo a progressivamente reconhecer-se e ser reconhecido por seus pares e professores como um membro desse contexto. Esse processo, que se diferencia, obviamente, a depender de inúmeras variáveis, como o gênero, por exemplo, pode revelar-se extremamente complexo, se associado a outros, como o de transição para a maternidade, que, no caso das jovens participantes da pesquisa, se deu no percurso da formação superior.

Quando isto ocorre, a jovem, no domínio da vida acadêmica e em sua passagem para o status de universitária, "mergulha nos códigos que 
definem esta organização" (COULON, 2008, p. 81), e se depara com as inúmeras solicitações desse novo contexto: resenhas, leituras, artigos, seminários, iniciação científica, além da presença em sala de aula. Todas essas tarefas, associadas a uma lógica universitária de "exclusividade" e "lealdade não-partilhada", como assinalam Wolf-Wendel e Ward (2005), não são deixadas atrás do portão da faculdade, quando a jovem volta para casa. Ao contrário, as tarefas relacionadas à posição de estudante universitária participam do cotidiano doméstico da jovem, e se cruzam com as demandas de sua criança, dialogando, não sem conflitos, com a posição de mãe. Decorrem, então, desse difícil processo, os muitos desafios que enfrenta quando tenta conciliar universidade $e$ maternagem. Assim, a resposta de Marta, a mais jovem das entrevistadas, à pergunta norteadora da entrevista ${ }^{4}$ nos revela o verdadeiro malabarismo que uma jovem universitária precisa fazer para conciliar dois universos tão distintos e exigentes como a maternagem e a academia:

Eu acho difícil, difícil porque a demanda da faculdade é muito puxada, exige muita dedicação e às vezes eu não consigo conciliar. Já deixei de fazer várias disciplinas, já tranquei, já abandonei, já fiz de tudo e eu acho que vou demorar, eu não vou me formar junto com as pessoas com quem eu entrei, porque eu tranquei e tal... e também em casa, às vezes eu deixo de ficar com ele pra fazer trabalho, eu deixo ele fazendo qualquer atividade sozinho pra poder estar fazendo uma resenha, um artigo, lendo um livro, um texto, qualquer coisa. Eu acho que a proximidade com ele fica comprometida, e na faculdade também eu não consigo fazer nada $100 \%$. (Marta, 21 anos)

Observem que Marta já começa a sua narrativa destacando a dificuldade em conciliar, de forma razoável, as posições de mãe e universitária, confirmando os dados das pesquisas em torno da temática, que fazem referência às instituições universidade e maternidade, como instituições ávidas. Segundo Marta, “a demanda da faculdade é muito puxada” e exige muita dedicação, tornando difícil a conciliação, visto

4 Como você descreve a experiência de ser mãe e universitária ao mesmo tempo? 
que a maternidade, nos moldes em que ainda a vivemos, também exige muito da mulher. Nessa condição e contexto, a jovem mulher precisa dialogar, no domínio da vida familiar, com prescrições de gênero, que associam mulher a cuidados parentais e tarefas domésticas - além de confrontar-se, cotidianamente, com os desafios inerentes ao processo de afiliação intelectual e institucional (COULON, 2008), pelo qual estudantes de primeiro ano, como ela, passam.

Como resultado, a itinerância estudantil desta jovem é marcada por várias interrupções: trancamentos, abandonos e faltas, como ela mesma afirma: "Já deixei de fazer várias disciplinas, já tranquei, já abandonei, já fiz de tudo, eu acho que vou demorar, não vou me formar junto com as pessoas com quem eu entrei. Nesta última fala de Marta, é possível notar que as interrupções significam mais que a desaceleração do processo formativo, elas implicam quebras de vínculos afetivos, e podem representar, para uma estudante na sua situação, ainda conquistando a condição de afiliada, uma passagem dolorosa e pouco estimulante. Além de fazer um desligamento forçado de sua turma de origem, ela constrói com seus pares uma relação pouco consistente, o que dificulta a comunicação em torno dos assuntos acadêmicos, que circulam entre pessoas e grupos vinculados afetivamente e cotidianamente.

O fato é que são muitas as demandas acadêmicas que competem com as demandas rotineiras da maternagem: alimentar, cuidar, brincar, levar para a creche etc., tarefas nem sempre partilhadas entre os casais. Diante de tantas solicitações e da dificuldade em equacioná-las de forma positiva, a sensação descrita pela jovem é de não conseguir fazer nada $100 \%$, ou seja, de não se entregar completamente às atividades acadêmicas e não corresponder, satisfatoriamente, a nenhuma das duas posições. A alternativa encontrada para os impasses da conciliação é deixar a criança fazendo uma atividade qualquer, nas palavras de Marta, enquanto realiza os trabalhos da faculdade. Mas como ela mesma destaca, nesse momento, o sentimento é de estar comprometendo a sua relação com o filho. No discurso dela, como será possível observar ao longo da breve descrição da narrativa de sua itinerância, basicamente 
centrada nas experiências referentes ao período após o nascimento da criança, o dilema da conciliação é acentuado inúmeras vezes, mesclado a uma série de interferências conjugais e intergeracionais que resultam num conjunto de sentimentos ambíguos em torno da experiência de tornar-se mãe.

Como afirma Miller (2005), a experiência subjetiva de ser mãe, em contraste com as "imagens antecipadas" acerca da maternidade, pode lançar a vida de mulheres em uma temporária confusão. Quando esta experiência está associada às exigências acadêmicas, como podemos notar, a situação revela-se ainda mais complexa. São muitas as mudanças, envolvendo um verdadeiro processo de reconstrução do self para abarcar não apenas a nova posição: a de mãe, mas para refazer uma outra - a de universitária - que vinha se construindo dentro de um determinado padrão, e que, após o nascimento do filho, precisa adequarse à nova situação. Nesse contexto, o exercício da conciliação torna-se um dos maiores desafios, e se faz no confronto com os diversos discursos - morais, sociais, culturais e políticos - acerca da maternidade na experiência juvenil. É nesse momento que a experiência se entrelaça com as dimensões das relações intergeracionais e de gênero, denunciando o caráter dialógico do tornar-se mãe no contexto acadêmico, que não se limita apenas ao diálogo entre o eu-mãe e o eu-universitária, apresentado até aqui, mas envolve muitos outros.

Eu também pago o prejuízo, e eu acho que ele tem influência também da minha sogra, ela é muito maternal, muito mãezona, ela acolhe os filhos, ele mamou até quatro anos, a mãe dele amamentou ele até quatro anos, por aí você tira que ela é uma pessoa muito dedicada à família, aquela coisa... Ela [a sogra] começou a faculdade com 29 anos eu acho, tarde com relação à vida acadêmica, eu comecei com 18 , e aí ele fica meio que comparando assim, porque eu não quero parar, quero viver minha vida, quero ser independente também. (Marta, 21 anos)

Ao referir-se a seu companheiro, Marta revela que ele sofre influências de sua sogra, e não poderia ser diferente, pois que é no contexto 
da família de origem que aprendemos os papéis de gênero. Esses aprendizados tornam-se parte das relações conjugais que se constroem no presente, sempre ancoradas no lastro do passado, ainda que se orientem em direção ao futuro. Isto ocorre porque a dependência de processos relacionais com o outro, como asseveram Rosseti-Ferreira, Amorim e Silva (2004), coloca essas jovens e seus companheiros em jogos interativos, impregnados dos signos culturalmente compartilhados, que vão abrindo e/ou interditando posições possíveis de serem ocupadas por essas estudantes-mães. Essa multiplicidade de vozes que compõem o mundo social e dialogam no self, submetem as jovens mães, mas, ao mesmo tempo, preservam a abertura para a inovação e para a construção de novos posicionamentos e processos de significação.

Nesse importante processo de transição, as jovens mobilizam diferentes tipos de recursos: internos, experiências e habilidades; e externos, como pedir uma ajuda da família ou de outras pessoas de sua rede de sociabilidade, acessar uma política de assistência, como a creche, por exemplo, ou pedir um conselho, o que possibilita a construção de significados em torno de sua própria experiência. (ZITTOUN, 2003) Dentre os recursos utilizados por Sara e pelas outras entrevistadas para a reorganização de suas vidas, construindo novas significações da sua experiência, a família e a creche aparecem como fundamentais. Esta última - a creche da universidade - surge, na narrativa de Sara, como o recurso externo que lhe possibilitou ficar ao lado de sua filha, assumindo sua responsabilidade, como ela pontua, permitindo-lhe aprender a ser mãe.

Minha mãe não queria que eu trouxesse Nina. [... minha mãe queria que eu voltasse à mesma vida, voltasse a sair com meus amigos, voltasse a trabalhar. Mas aí eu não quis porque essa é uma responsabilidade minha, é uma obrigação minha. Eu nunca quis, e graças a Deus eu consegui o auxílio da creche, porque se não fosse a creche, talvez Nina não estivesse comigo hoje, estivesse com meus pais no interior. E eu quero saber... se eu não cuidasse dela hoje, eu nunca saberia ser mãe. (Sara, 23 anos) 
Em parceria com a creche - espaço que faz parte da rede social de apoio destas jovens estudantes - suprindo, muitas vezes, a ausência de suas famílias, haja vista que algumas delas têm origem no interior da Bahia, Sara constrói-se mãe e assume, em certo sentido, o status de adulta, na medida em que toma para si mesma a responsabilidade, não apenas sobre sua vida, como sobre a vida de sua filha. Tal como assevera Arnett (1997, 1999), referindo-se ao processo juvenil de transição para a vida adulta, não há dúvida de que a parentalidade, o tornar-se pai ou mãe, é frequentemente suficiente para construir um sentido subjetivo do status de adulto. Aqueles que já tiveram filho tendem a ver esta experiência como o mais importante marcador da transição para a vida adulta deles mesmos. Mas é importante observar, todavia, que com a parentalidade, as explorações, inclusive formativas e profissionalizantes, que ocorrem no período relativo à transição para a vida adulta, e podem incluir a passagem e permanência no contexto universitário, tornam-se bastante restritas. Com a parentalidade, o foco muda, inexoravelmente, da responsabilidade sobre a sua própria vida e pessoa para a responsabilidade sobre a vida do outro. (ARNETT, 1999)

Final de semana, eu não abro mão dela. Eu posso estar o que for, atolada do que for, mas eu tenho que estar com ela. [...] Ela fica o dia todo aqui [na creche], aí, às noites e ao amanhecer, é o tempo que eu tenho com ela. Aí, eu procuro estar com ela, estar brincando. Dar banho, só eu dou banho nela. Aí fico conversando com ela, criando um vínculo, porque eu acho que eu sou muito ausente na vida dela pelo fato dela estar a maior parte do tempo na creche. (Sara, 23 anos)

Como Sara não tem muito tempo, em função dos estudos, ela aproveita o início das manhãs e à noite para ficar com a filha, mas, ainda assim, torna-se quase inevitável o sentimento de culpa. Este parece fazer parte da experiência de todas as entrevistadas, que se esforçam ao máximo para estar com seus filhos, ainda que isso acabe repercutindo em seus estudos. 
Mas é muito difícil você conciliar faculdade e depois vir uma criança. É difícil você se dar bem nas coisas. É difícil você cumprir toda a meta, toda a carga horária, você poder aproveitar as disciplinas. Porque geralmente você não aproveita como você aproveitaria se não tivesse um filho. Acaba que seu rendimento cai, cai muito. Meu rendimento caiu muito, eu perco muitas disciplinas, perco não, perco muitas aulas, eu nunca perdi. Perco muitas aulas, faço segunda chamada por conta dela, ela fica doente. Ainda mais eu que sou só eu e ela. (Sara, 23 anos)

Como é possível notar, no relato de Sara e das outras entrevistadas apresentadas até aqui, não são poucas as dificuldades em conciliar as demandas acadêmicas e maternas. Não obstante a tentativa de organizar o tempo de modo a dar conta de ambas as demandas, sempre ocorrem os imprevistos, como Sara refere: Perco muitas aulas, faço segunda chamada por conta dela, ela fica doente. Desse modo, fica muito complicado manter o "rendimento" escolar em função das faltas e dos contratempos que acabam resultando, em alguns casos, em trancamentos e até abandonos. Assim, a queda no coeficiente de rendimento ou escore, que é um dado relevante na UFBA, torna-se inevitável. Como a universidade ainda mantém uma visão tradicional acerca dos processos de transição para a vida adulta, que pressupõe uma perspectiva linear, de sucessão passo a passo, estudantes que vivem experiências de simultaneidade e dividem o seu tempo entre trabalho ou maternidade e vida acadêmica, acabam tendo algumas dificuldades nesse contexto.

\section{CONSIDERAÇÕES FINAIS}

Como mencionamos no início deste capítulo, a entrada na vida universitária vem se tornando um marco cada vez mais importante para os jovens das novas gerações. Porém, é importante ficar atento para o fato de que estar na universidade, como destaca Sampaio (2008), associase a inúmeras outras inserções e exigências desenvolvimentais que irão modular as experiências individuais e coletivas no espaço acadêmico. 
Experiências muitas vezes decorrentes do distanciamento que vem se construindo hoje, entre o exercício da sexualidade na juventude e a entrada na vida adulta. Nesse sentido, a universidade precisa ser repensada, devendo ser capaz, não apenas de oferecer as condições necessárias para atender às demandas de formação dos jovens de diferentes segmentos, como acolhê-los em suas dificuldades, criando estruturas de suporte que evitem o fracasso e o abandono. (SAMPAIO, 2008)

Afinal, não podemos desconsiderar que "a escola é invadida pela vida juvenil” (DAYRELL, 2006) e, no caso da universidade, isso inclui os processos de transição para a vida adulta e a maternidade/paternidade. Tais processos apontam, por exemplo, para a necessidade do provimento de políticas e serviços de planejamento familiar destinados à população juvenil, bem como para o imperativo de políticas de assistência, que possam dar garantias básicas de apoio à experiência de transição para a maternidade nesse contexto, seja no período da gravidez ou após, com a retomada dos estudos.

Esta discussão, a nosso ver, deve envolver a participação de toda a comunidade universitária, que precisa empreender esforços na busca de políticas que de fato ultrapassem o enfoque assistencialista e alcancem o patamar dos direitos e da cidadania. É importante considerar, tal como observa Coulon (2008), que estudantes que trabalham e, como estamos vendo, que têm filhos também, possuem restrições pessoais, que se juntam às dificuldades já encontradas pelos estudantes de tempo integral, na organização de seus horários. Seus quadros de horário devem respeitar, ao mesmo tempo, as exigências curriculares e as demandas da maternagem, que incluem, por exemplo, amamentar, deixar na creche às sete da manhã, retornar para buscar às 13 horas ou às 18 horas, dentre outras responsabilidades.

Desse modo, as políticas que pretendem funcionar como ações facilitadoras da permanência dos estudantes, não podem deixar de incluir e reconhecer as mulheres como grupo social em desvantagem de permanência ou desempenho, quando na condição de mães. Este aspecto é de fundamental importância para inclusão de pautas reivindi- 
catórias voltadas para o conjunto da população universitária feminina, e que possam contribuir, por exemplo, para dar visibilidade às demandas das estudantes que se tornam mães no percurso da formação superior. (URPIA; SAMPAIO, 2009) Demandas que, sem dúvida, apontam para o investimento numa política de assistência central: a ampliação e melhoria da qualidade de atendimento das creches universitárias, que, muitas vezes sem recursos e invisibilizadas no cenário das discussões sobre educação superior, lutam hoje para sobreviver neste contexto.

Contudo, é bom sublinhar que isso só não basta, é imperioso para que estas jovens possam dar continuidade a seus estudos, que outros mecanismos de apoio sejam implementados, a saber: o incentivo aos processos de retomada dos estudos, após o nascimento de seus filhos, através, por exemplo, de uma oferta de horários que lhes permitam amamentar e cursar os componentes curriculares, sem a necessidade de trancamentos; a possibilidade de negociação de horários mais flexíveis no período em que as estudantes-mães fazem a inserção de suas crianças no contexto-creche; entrega posterior de material de estudo combinado com o(a) professor(a), de modo a justificar faltas, evitando reprovação, no caso da criança precisar se ausentar da creche por motivo de saúde; além da possibilidade da jovem com gravidez de risco finalizar o semestre com atividades domiciliares, mesmo não sendo os três últimos meses da gravidez, evitando o trancamento do semestre e até o abandono do curso, quando for confirmado, por laudo médico, o problema de saúde da estudante-gestante.

\section{REFERÊNCIAS}

AQUINO, Estela M. L. Gênero e Ciência no Brasil: contribuições para pensar a ação política na busca da equidade. In. Pensando Gênero e Ciência. Encontro Nacional de Núcleos e Grupos de Pesquisas - 2005-2006. Brasília, 2006, PP. 11-18.

ARNETT, J. J. Emerging adulthood: a theory of development from the late teens through the twenties. American Psychologist, v. 55, n. 5, p. 469-480, 1999. 
ARNETT, J. J. Young people's conceptions of transition to adulthood. Youth Society, v. 29, n. 3, p. 3-23, 1997. Disponível em: <http://www.periodicos. capes.gov.br/portugues/index.jsp>. Acesso em: 21 jun. 2007.

BRANDÃO, E. R. Individualização e vínculo familiar em camadas médias: um olhar através da gravidez na adolescência. 2003. Tese (Doutorado Saúde em Coletiva), Instituto de Medicina Social, Universidade do Estado do Rio de Janeiro, Rio de Janeiro, 2003.

CAMARANO, A. A. (Org.). Transição para a vida adulta ou vida adulta em transição? Rio de janeiro: IPEA, 2006.

CAMARANO et al. Caminhos para vida adulta: as múltiplas trajetórias dos jovens brasileiros. Última Década, Cidpa Valparaíso, n. 21, p. 11-55, 2004. Disponível em: $<w w w . s c i e l o . c l / p d f / u d e c a d a / v 12 n 21 / a r t 02 . p d f>$. Acesso em: 16 jun. 2007.

COFFEY, A. The ethnographic self: fieldwork and the representation of identity. London: SAGE Publications, 1999.

COULON, A. A Condição de estudante: a entrada na vida universitária. Salvador: EDUFBA, 2008.

DAYRELL, J. A escola "faz" as juventudes? Reflexões em torno da socialização juvenil. Educação e Sociedade, Campinas, v.28, n.100, p. 11051128, out. 2007. Disponível em: <http://www.scielo.br/pdf/es/v28n100/ a2228100.pdf> Acesso em: 21 maio 2008.

HERMANS, H. J. M. The dialogical self: toward a theory of personal and cultural positioning. Cultural Psychology, Canada, v. 7, n. 243, 2001. Disponível em: <http://jfi.sagepub.com>. Acesso em: 11 abr. 2007. HEILBORN, M. L.; CABRAL, C. S.; BOZON, M. Gênero e carreiras reprodutivas de jovens brasileiros. In: XV ENCONTRO NACIONAL DE ESTUDOS POPULACIONAIS, ABEP, 2006, Caxambu, MG. Anais... Caxambu, MG: ABEP, 2006. Disponível em: <http://www.abep.nepo. unicamp.br/encontro2006/docspdf/ABEP2006_607.pdf >. Acesso em: 2 jul. 2009.

INSTITUTO BRASILEIRO DE GEOGRAFIA E ESTATÍSTICA. Banco Multidimensional de Estatísticas (BME). Censo. 2000. Disponível em: <http://www.ibge.gov.br/home/> Acesso em: 30 maio 2008. 
MANSON, L. L.; GOLDEN, M. Do Babies Matter? The Effect of Family Formation on the Lifelong Carreers of Academic Men and Woman.

Academe, v. 88, n. 6, p. 21-27, 2002. Disponível em: <http://www.aaup.org/ AAUP/pubsres/academe/>. Acesso em: 27 maio 2008.

MILLER, T. Making Sense of Motherhood. New York: Cambridge University Press, 2005.

PAIS, J. M. A construção sociológica da juventude - alguns contributos. Análise Social, n. 25, p. 139-165, 1990. Disponível em: <http://analisesocial. ics.ul.pt/documentos/1223033657F3sBS8rp1Yj72MI3.pdf > Acesso em: 13 ago. 2008.

PERES, S. O.; HEILBORN, M. L. Cogitação e prática do aborto entre jovens em contexto de interdição legal: o avesso da gravidez na adolescência. Caderno de Saúde Pública, v. 22, n.7, p. 1411-1420, 2006.

ROMANELLI, G. O Significado da Educação Superior para duas gerações de famílias de camadas médias. Revista Brasileira de Estudos Pedagógicos, v. 76, n. 184, p. 445-476, 1995. Disponível em: <http://emaberto.inep.gov. br/index.php/RBEP/article/view/268/269>. Acesso em: 10 de set. 2008. ROSSETTI-FERREIRA, M. C.; AMORIM, K. de S.; SILVA, A. P. S. Rede de Significações: alguns conceitos básicos. In: ROSSETTI-FERREIRA, M. C. et al. Rede de significações e o estudo do desenvolvimento humano. Porto Alegre: ArtMed Editora, 2004.

SAMPAIO, S. M. R. Observatório da vida estudantil: histórias de vida e formação na educação superior. In: III CONGRESSO IINTERNACIONAL SOBRE PESQUISA (AUTO) BIOGRÁFICA, 2008, Natal. Anais... CDROM.

WOLF-WENDEL, L. E.; WARD, K. Academic life and motherhood: variations by Institutional Type. Higher Education, n. 52, p. 487-521, 2005. Disponível em: <http://www.periodicos.capes.gov.br/portugues/index. jsp>. Acesso em: 5 abr. 2007.

URPIA, A. M. de O.; SAMPAIO, S. M. R. Tornar-se Mãe no Contexto Acadêmico: dilemas da conciliação maternidade - vida universitária. Revista Recôncavos, v. 3, n. 2 p. 30-43, 2009. Disponível em: <http://www.ufrb.edu. $\mathrm{br} /$ reconcavos/pdf/ana_maria_de_oliveira_urpia_-_sonia_maria_rocha sampaio.pdf $>$. Acesso em: 22 de abril, 2010. 
VALSINER, J. Culture in minds and societies. New Delhi: Sage, 2007.

. Scanffolding within structure of Dialogical Self: Hierarchical dynamics of semiotic mediation. New Ideas in Psychology, p. 1-10, 2003.

WANG QI; BRONKMEIER, J. Autobiographical remembering as cultural pratice: the interplay between memory, self and culture. Culture $b$ Psychology, v. 8 n.45, 2002. Disponível em: <http://www.periodicos.capes. gov.br/portugues/index.jsp>. Acesso em: 13 de jun. 2007.

ZITTOUN, T. The use of resources in developmental transitions. Culture \& Psychology, Canadá, USA, v. 9, n. 4, p. 415-448, 2003. Disponível em: <http://cap.sagepub.com> Acesso em: 11 abr. 2007. 


\title{
JUVENTUDE E POLÍTICA observando a Ufba ${ }^{1}$
}

\author{
0 \\ ALLAN JEFFREY VIDAL MAIA \\ CHRISSIE FERREIRA DE CARVALHO \\ LUIZ FERNANDO CALAÇA DE SÁ JÚNIOR \\ MARCELO NAVARRO \\ RAQUEL BAROUH \\ RENATA MOREIRA \\ SONNIA MARIA ROCHA SAMPAIO
}

\section{POLÍTICA, JUVENTUDE, MINORIAS E AÇÕES AFIRMATIVAS}

A discussão sobre a participação política da juventude é atravessada por uma questão fundamental que interroga sobre o seu incremento ou declínio, nas três ou quatro últimas décadas. $O$ tema é objeto de pesquisadores, tanto do campo da juventude quanto do campo das ciências políticas, que se dividem entre a emergência de um apoliticismo juvenil ou o surgimento de novas formas de engajamento político.

1 Artigo derivado de trabalho de pesquisa e intervenção desenvolvido nas disciplinas Psicologia Escolar I e II, sob orientação da Profa. Dra. Sônia Sampaio, no ano de 2008, segundo semestre. 
Os jovens se apresentam, dentro do cenário político brasileiro, como uma camada da população com pouca representatividade política. Apesar da população de jovens entre 15 e 25 anos constituir cerca de $20 \%$ da população, estes se encontram num lugar à margem dos processos decisórios, no que diz respeito a políticas públicas elaboradas pelo governo brasileiro, o que aponta para uma necessidade de ocupação desse espaço de representatividade. Esse problema estaria relacionado a um pretenso vazio na formação política dos jovens que impõe dificuldades à ocupação de espaços e posicionamentos políticos frente a temas de relevância para o conjunto da sociedade.

É verdade que, uma formação no sentido de integrar os aspectos políticos, cidadania e direitos humanos, não constitui foco das preocupações educativas de professores e gestores em espaços educativos de forma geral, sejam eles públicos ou privados. O contato do segmento jovem com a dimensão política da vida em sociedade e, seu eventual engajamento, acaba se dando de forma alternativa, em outros espaços, como grêmios, diretórios estudantis, partidos políticos ou grupos ligados a movimentos sociais de proximidade, que dizem respeito a questões transversais e que interessam a grupos específicos de jovens. Situações emergentes e ligadas ao cotidiano podem, igualmente, favorecer o contato com temas e questões políticas.

Castro (2004) inclui, seguindo essa perspectiva, os jovens entre outros grupos minoritários, como negros, mulheres e homossexuais, que pleiteiam espaços de participação política e ações de tipo afirmativo, tanto de caráter local quanto global. A autora discute a heterogeneidade que caracteriza os jovens, envolvendo aspectos como gênero, raça, classe social, orientação sexual e escolarização, o que aponta para a complexidade do fenômeno juventude. Esses múltiplos pertencimentos permitem a permeabilidade dos jovens a outros movimentos políticos, de caráter afirmativo ou de discriminação positiva, como advogam alguns.

Na Universidade, como espaços institucionalizados, previstos para a participação política, temos os Diretórios ou Centros Acadêmicos 
(DA ou CA) e o Diretório Central dos Estudantes (DCE), funcionando como territórios legitimados de representatividade, voltados, mais especificamente, para as políticas estudantis e/ou educacionais. Neles, os jovens buscariam garantir o debate desses temas e conjunturas diversificadas, estabelecendo, eventualmente conexões com outros grupos e movimentos político-sociais e de militância. Mas, além do movimento estudantil universitário, é possível encontrar estudantes vinculados a outros grupos que vão de partidos políticos - autoconsiderados de esquerda, principalmente - até grupos de militância específicos, nucleados a partir de temas relativos à diversidade/identidade, como os movimentos negro, feminista e GLBT (gays, lésbicas, bissexuais e transgêneros) ou, mais contemporaneamente, LBGT ou LBGTTTS22.

Esses espaços tendem a servir como contextos de aprendizagem política - uma vez que neles os jovens acessam discussões sobre política, cidadania e direitos humanos, oportunizando uma formação fragilizada em praticamente todos os currículos formalizados das escolas e universidades ${ }^{3}$, onde o estudo e a discussão política não são privilegiados. Apenas alguns cursos de ciências humanas permitem que discussões mais amplas sobre a conjuntura política e social ocorram de forma mais frequente. Um aspecto interessante e contraditório a destacar: se, por um lado, esses espaços de aprendizagem não possibilitam uma adequada formação política e social, por outro, eles são comumente considerados como promotores privilegiados desse tipo de formação.

\section{IDENTIDADE E INSERÇÃO POLÍTICA}

A realidade social é considerada como processual, dinâmica e em permanente construção, de acordo com o espaço-tempo específico consi-

2 A sigla oficialmente usada no Brasil para a diversidade de manifestações de gênero, desde junho de 2008, quando da Conferência Nacional GLBT, é LBGT (Lésbicas, Gays, Bissexuais e Travestis, Transexuais e Trangêneros). O "s" eventualmente utilizado, refere-se aos simpatizantes.

3 O currículo dos atuais Bacharelados Interdisciplinares, implantados na UFBA em 2009, contam com o componente curricular "Estudos da Contemporaneidade", cujo conteúdo privilegia o tratamento de temas políticos e da atualidade local e nacional. 
derado e com os indivíduos que participam de sua elaboração cotidiana. As ações coletivas constituem-se como uma tentativa de significação e possibilidade de mudança do que se apresenta enquanto realidade para esses indivíduos. Estes agrupamentos coletivos, movimentos sociais e políticos, constroem suas identidades enquanto grupos, a partir do contexto das relações de poder que os envolve.

Estas ações coletivas lutam por direitos sociais e igualdade, o que inclui a defesa do reconhecimento social de suas peculiaridades e diferenças em meio a um contexto social fortemente homogeneizante. (PRADO, 2001) É importante que estes "sujeitos históricos" tenham o máximo possível de informações, além de possibilidades de discussão e representatividade no espaço público, a fim de que possam realmente contribuir para a definição das orientações e decisões seguidas pela comunidade. (ENRIQUEZ, 2006)

É através do desenvolvimento de novas formas de relacionamento voltadas para o espaço público, tais como a solidariedade, a hospitalidade e o respeito, que a pluralidade e a experimentação de novas possibilidades de estar no mundo permitirão a verdadeira inclusão de segmentos que não partilham de forma equânime da vida social. A atitude política é muitas vezes difícil de ser adotada, na medida em que lutar contra antigas crenças e valores conservadores é um processo árduo e lento. Os jovens que entram nesse cenário enfrentam essas dificuldades que, apesar da exigência que representam, criam mudanças e constroem espaços de atuação mais coletivos e ampliados.

A inserção política de uma parcela dos estudantes pode ser observada dentro da universidade, sendo caracterizada pela articulação interna e externa dos diferentes movimentos, da importância do diálogo e das discussões, da organização de encontros, fóruns e eventos estudantis que conectam política ao exercício prático da cidadania. Os espaços criados e ocupados pelos jovens que se engajam politicamente, mesmo que inadvertidamente, terminam por incluir a dimensão da subjetividade e o desenvolvimento do pensamento crítico que dá acesso à esfera pública e a relações humanas dignas. 
A mudança e a construção de novas metáforas, imagens, significados e realidades socialmente compartilhadas somente é possível quando o indivíduo assume o risco do confronto com o novo. Quando ele se desloca da esfera da segurança e se abre ao convívio com os diferentes, ao desafio do estranho e do desconhecido, sem medo, sem indiferença ou apenas tolerância, mas a partir da aceitação de formas mais flexíveis no convívio social. (ORTEGA, 2003) A juventude tem como característica do seu desenvolvimento a atração pelo novo e a possibilidade de reconstruir a sua própria realidade, o que se dará através de suas redes de relações onde ela tem espaço para elaborar questionamentos a respeito das condições de sua existência.

\section{FALANDO DE MÉTODO}

Esse trabalho, que buscava um conhecimento preliminar sobre as relações entre juventude e política na UFBA, utilizou diferentes técnicas de investigação dentro da abordagem qualitativa em pesquisa social, voltando-se para a compreensão dos modos como cada estudante, que se dispôs a participar como informante, significava sua experiência de militância em seu grupo de atuação específico.

Os recursos etnográficos utilizados para coletar os dados foram a pesquisa participativa, os diários de campo e entrevistas presenciais semiestruturadas. O uso de metodologia diversificada adequou-se bem às possibilidades de acesso aos entrevistados. Participaram do estudo oito universitários que pertenciam a quatro diferentes grupos e movimentos políticos ligados à universidade: dois estudantes de DAs/CAs e DCE (Representação Estudantil), um estudante da Luta Antimanicomial, quatro estudantes do grupo de discussão e militância LGBT e um estudante do Movimento Passe Livre.

O processo de elaboração das entrevistas consistiu na formulação de perguntas e solicitação de informações sobre o histórico dos grupos pesquisados, a inserção do entrevistado no grupo, suas percepções sobre esse espaço, outras participações em movimentos sociais e/ou 
políticos, influência destes para a sua vida pessoal/profissional e a relação dos grupos com o ambiente universitário. As entrevistas foram realizadas entre maio e junho de 2008 e tratadas, agrupando-se os temas em alguns eixos temáticos, a saber: inserção no grupo/movimento, como se dá a atuação, associação com o curso e a comunidade, interações com outros grupos, influência familiar, relação da atividade política com a Universidade. Os resultados serão apresentados por grupo entrevistado.

\section{A REPRESENTAÇÃO ESTUDANTIL}

Os estudantes matriculados nos cursos de História e de Física participavam de seus respectivos Centros Acadêmicos; um deles, o estudante de História, D., era igualmente membro do DCE.

Esse estudante, desde o primeiro ano da faculdade, em 2005, participou do CA do seu curso, pois sempre se sentiu motivado para esse tipo de ação; no ano de 2007, integrou uma das chapas candidatas e eleita para o DCE. A sua aproximação começa um ano antes, através da participação em um grupo de debates interessado em concorrer às eleições para dirigir essa entidade estudantil. A representação estudantil no DCE foi, para ele, a “[...] possibilidade de militância dentro da própria universidade $[. .$.$] ”, considerando que a sua participação no$ movimento social é diferenciada por ser negro. $\mathrm{O}$ estudante em questão, que milita também em um partido político, considerado por ele de esquerda, acredita ser possível agregar os diferentes espaços de ação política onde circula, através do diálogo e da promoção do debate sobre Universidade e Educação.

D. afirma priorizar a militância em relação à formação acadêmica e percebe mudanças pessoais importantes relacionadas a essas suas experiências no campo político:

[...] isso tudo me proporciona espaço de formação política o que me acaba levando para outros lugares. Tenho hoje um espaço ampliado, falo com Deus e o mundo; converso com 
alunos, professores, servidores. Minhas relações sociais e meu posicionamento estão em outros parâmetros, há tanto a convivência como as disputas [...] Estou, constantemente recebendo e fazendo críticas $[\ldots]$.

Outro elemento relevante considerado por ele é, justamente, o fato da oportunidade da juventude debater sobre assuntos políticos, além de beneficiar-se de uma espécie de formação para a organização: disputar, compreender e intervir na gestão de espaços de caráter político.

O estudante de Física sempre se mostrou interessado pelas discussões políticas. O que o conduziu a participar do DA do seu curso foi o fato desta estrutura de representação institucional estudantil estar abandonada há cinco meses, depois do final da gestão anterior. Ele relata, na entrevista, um desejo grande de fazer política e trazer mudanças significativas ao espaço universitário, sendo bastante otimista quanto às possibilidades de reativar o Diretório. Mas, para conseguir seu objetivo, ele teve de enfrentar a crítica de colegas, descrentes no que diz respeito ao papel transformador dos estudantes e do movimento estudantil: [...] sempre foi assim e nada muda de fato. Mesmo que sua motivação em entrar para a política estudantil universitária fosse anterior à sua entrada na educação superior, ele confessa ter passado por momentos de desmotivação, afastando-se do movimento para dedicar-se exclusivamente à conclusão do seu curso e ao trabalho.

Os dois estudantes entrevistados são exemplos que caracterizam a representação estudantil em espaços de representação legitimados pela própria universidade. Ambos trazem, como traços de sua história pessoal, o desejo prévio de fazer política, descobrindo a universidade como um espaço propício para seu desenvolvimento nesse campo. Além disso, trazem à tona a importância da articulação dos diversos movimentos sociais, do diálogo e apoio entre eles, pela ação em rede e através da oportunização de discussões, fóruns e eventos estudantis que os vinculam ao mudo da política.

Entretanto, apesar dos seus desejos e prática efetiva, eles dizem das dificuldades enfrentadas, ao assumirem o lugar de representantes 
da comunidade estudantil, e consideram que o estudante é um importante coadjuvante do processo de constituição e transformação do espaço universitário. Grande relevância foi por eles atribuída ao período vivido pelos jovens nas universidades, vistas como espaços de possibilidades de movimentação político-social, difíceis de serem encontrados extramuros.

\section{O MOVIMENTO DE LUTA ANTIMANICOMIAL}

Segundo o Ministério da Saúde, a Reforma Psiquiátrica consiste em uma ampla mudança no atendimento público em saúde mental. Esse novo modelo visa assegurar o respeito aos direitos e à liberdade, o que deve resultar em uma mudança no tipo do tratamento: ao invés do isolamento, preconiza o convívio com a família e a comunidade. O movimento antimanicomial, que ganhou bastante visibilidade política, a partir dos anos 80 , segue crescendo como uma das fundamentais forças dentro da reforma psiquiátrica brasileira. Nesse movimento, acredita-se que, através da interação entre a realidade dos loucos com a dos "nãoloucos”, se encontra a melhor resposta para a melhoria da condição de vida de todos. Nessa perspectiva, o Grupo de Trabalho da Luta Antimanicomial Eduardo Araújo foi criado, a partir da iniciativa de alguns estudantes do curso de Psicologia da UFBA, em 2006, com o objetivo de produzir conhecimento acerca da Reforma Psiquiátrica; disseminar a discussão sobre os rumos que este movimento vem tomando, sobretudo na cidade de Salvador, e efetivar práticas que contribuam para os movimentos sociais engajados na Luta Antimanicomial.

A entrevista foi realizada com I., 22 anos, estudante do curso de Psicologia da Universidade Federal da Bahia, integrante desse coletivo, também atuante na assessoria da associação $\mathrm{AMEA}^{4}$.

A inserção de I. no movimento antimanicomial deu-se através do convite de um colega de curso, que o apresentou ao grupo de trabalho.

4 Associação Metamorfose Ambulante de Usuários e Familiares dos Serviços de Saúde Mental. 
Ele se lembra da primeira atividade exercida, já como membro - a visita a um hospital psiquiátrico -, como o fator importante para a sua permanência no grupo: [...] foi muito marcante pra mim a visita que eu fiz ao Hospital Mário Leal [...] pensei: 'não é possível, eu tenho que fazer alguma coisa'. Ele indica o próprio grupo como fator relevante para o seu ingresso e continuidade: Eu diria que eu me senti muito acolhido [...] com certeza esse fator também é importante [...] Eu conheci pessoas incríveis, muito inteligentes, muito críticas. Isso pra mim é fundamental.

Sua inserção nesse grupo de trabalho contribuiu de maneira positiva para a sua postura como estudante do curso de Psicologia: Ter encontrado uma causa pela qual lutar e que élegítima e que tem uma importância muito grande na vida das pessoas foi essencial no meu engajamento, até no curso, né? O exercício de algumas aptidões para o trabalho em grupo e a percepção de si mesmo foram igualmente dois pontos sublinhados: Até a coisa de ser antimanicomial é algo inerente à minha identidade [...] Tem também a coisa do ritmo e da responsabilidade [...] estar sempre trabalhando em grupo que requer muita essa objetividade.

Como resultado suplementar da sua ação na luta antimanicomial, I. desenvolveu uma postura crítica relativa à forma como o curso é conduzido, por não privilegiar, segundo ele, a formação profissional prática. A possibilidade de você sentir, de você ter um senso crítico sobre isso, se apropriar do que acontece, se apropriar e ver, nem se compara com qualquer disciplina. $\mathrm{O}$ estudante relata não observar incentivos ou contribuições consideráveis por parte da universidade em relação à atuação do seu grupo. Apenas a participação de um professor que, por já estar engajado no movimento, contribui individualmente para o seu desenvolvimento. Colaboração, incentivo, da faculdade pro movimento, eu não observo. Eu acho que teve um papel essencial a presença do professor $M$.

Dos depoimentos trazidos aqui, pode-se concluir que a fragilidade de atividades práticas curriculares voltadas para a formação adequada do futuro profissional e a carência de interesse acadêmico e curricular, nesse campo do conhecimento psicológico e psiquiátrico, contribuíram para a busca de uma forma de atuação e organização tanto acadêmica 
quanto política fora do território da universidade, e sem que esta se desse conta da contribuição formativa que um coletivo dessa natureza pode exercer sobre os estudantes e seu futuro.

\section{O MOVIMENTO DO PASSE LIVRE}

O estudante A., de 22 anos, participa do MPL - Movimento pelo Passe Livre, colabora com o Coletivo de Mídia Independente e é membro do Centro Acadêmico de um dos cursos de Engenharia da UFBA. Sua participação mais ativa se dá, entretanto, no MPL.

Segundo seu depoimento, o objetivo deste movimento é conquistar a gratuidade para os estudantes em transportes públicos e, a longo prazo, estender o benefício a toda a população. As Prefeituras Municipais seriam as responsáveis por subsidiar o serviço, utilizando recursos oriundos de multas de trânsito, IPVA e cartões de estacionamento da Zona Azul. O movimento origina-se, em 2005, em Porto Alegre, depois de manifestações ocorridas em outras cidades que demonstravam insatisfação, especialmente dos estudantes, com os aumentos das tarifas dos transportes. O coletivo tem uma proposta de estrutura horizontal, apartidária e autônoma, conta com vinte grupos atuantes no país e que vêm obtendo conquistas efetivas, facilitadas pela autonomia que cada grupo local possui. Em Salvador, os membros têm estudado o sistema de transporte público do município, além de discutir a gratuidade. O objetivo é entender como se constitui a relação do transporte com seus usuários e com a organização da cidade. Os militantes também visam disseminar as informações e reflexões produzidas no seio do coletivo, de modo a implicar a população.

O estudante fala de sua facilidade para se inserir em grupos de atuação política, resultado de influências no seio de sua família e da necessidade que sente em exercer sua cidadania e lutar por mudanças na sociedade. Além da própria família, a namorada, os amigos e os co-

5 MPL. 
letivos políticos dos quais participa são os vetores principais da sua formação política.

A participação de A. no MPL favoreceu uma modificação na sua percepção de mundo. Ele afirma que passou a [...] pensar em outra forma de contribuir para a sociedade. A. explica que os conhecimentos e reflexões que resultam de sua participação no movimento influenciam sua postura em outras áreas da vida:

[...] quando você entra em contato com essas pessoas, você expande essas noções pra vários setores da sua vida. Então isso mexe com a sua vida pessoal, mexe com a sua vida profissional, mexe com o tratamento que você dispensa a outra pessoa, mexe com a forma como você enxerga outra pessoa.

O estudante deixa claro em sua fala o poder que teria o engajamento político de promover o crescimento pessoal e humanístico, além de permitir ao jovem compreender importantes detalhes do mundo ao seu redor e que só são possíveis de decodificar através de ações desenvolvidas em grupos cooperativos.

\section{O MOVIMENTO LGBT}

Dentre os movimentos que organizam minorias, LGBT mostra-se bastante permeável a outros aspectos identitários, como gênero, cor da pele e pertencimento econômico-social, por estabelecer conexões com outros grupos minoritários, como os movimentos negros e feministas. Esses grupos trazem consigo uma diversidade muito grande de posturas, mas se unificam quanto à importância da subversão dos modelos considerados heteronormativos de sexualidade, ainda hegemônicos na contemporaneidade.

Identificamos, no contexto universitário, diferentes grupos vinculados ao movimento LGBT, com origem em diversos centros de ensino superior da Bahia e com atuação mais ou menos autônoma: o GGEBA (Grupo Gay da Escola de Belas Artes da UFBa), o KIU! (UFBa, UNEB, UCSal), além do DIADORIM (UNEB) e do UNISEX (FTC). Cada 
um desses grupos teve diferentes origens, porém tendo como principal motivo de sua criação a busca por igualdade de direitos.

A., um dos criadores do GGEBA, citado por Marcellus Bragg (2006), fala dos motivos que levaram à criação do grupo:

[...] a partir do que observamos de pequenos constrangimentos aos alunos mais assumidos pelos, assim digamos, caretas. E pelo fato de que estamos dispostos a colocar a Escola de Belas Artes dentro do roteiro da discussão GLBT. E, para isto, pretendemos interagir, fazer da nossa Escola um palco aberto para a homocultura, promovendo exposições, criando instalações, organizando conferências e agindo no sentido de se ampliar cada vez o conceito de normalidade da homossexualidade.

A criação do GGEBA se dá, justamente na afirmação de uma cultura homossexual, e a participação se dá pela via da produção artística. Como é evidenciado na fala de A., e reafirmado na abertura da comunidade do GGEBA no orkut:

Não é questão de militância.

Não é imposição sexual.

Não é autopreconceito.

É questão de produção.

É questão de respeito!

Z., um dos fundadores do GGEBA, confirma essa forma de "militância”, que se materializa através de expressão artística e no desenvolvimento de trabalhos sobre homoerotismo. Participar de mostras com essa temática parece-lhe ser a forma mais adequada para que a comunidade LGBT de sua escola se envolva em ações, por que não dizer, políticas. Essa alternativa não militante de exercer a política afirma-se através de um estilo de produção artística característico, defendido por Z., associado às múltiplas identidades que constituem o homoerotismo e o movimento LGBT. A preocupação, além da denúncia de discriminação e preconceito dentro da Universidade, é a de afirmação estética de formas de expressão do corpo e da sexualidade, o que se aproxima de aspectos presentes na teoria Queer (LOURO, 2001) e na arte sob sua inspiração. 
O GGEBA articula-se ao KIU!, outro grupo no formato de coletivo, criado em 2003, a partir de ações desenvolvidas junto ao DA. de História da UFBa, englobando membros de diversas universidades. Segundo W., um dos criadores do KIU!, este foi um dos grupos que ocuparam o espaço aberto às discussões sobre o tema, abertura essa que se deu historicamente a partir das discussões que aparecem na mídia, desde 2003. Essa delimitação histórica condiz com o panorama, indicado por Ramos e Carrara (2006), sobre a entrada das discussões LGBT no meio acadêmico brasileiro.

Sobre a Universidade, $\mathrm{W}$. percebe que ela [...] ainda está muito longe de apoiar as discussões sobre sexualidade. Quando apresentaram filmes do Mix Brasil - festival importante e reconhecido no circuito LGBT - no pátio Raul Seixas (São Lázaro, FFCH/UFBA), ouve manifestações contrárias de alguns professores. A Direção da Faculdade propôs que se realizasse a atividade em uma das salas de aula, mas a proposta do KIU! é, justamente a de [...] trazer as discussões e ocupar os espaços públicos [...], onde circulam pessoas de vários segmentos, heterossexuais, evangélicos etc.

Completando, W. afirma:

[...] a Universidade é um espaço que reproduz a sociedade heteronormativa, patriarcal, sendo, a ausência de travestis, um indício de como há essa exclusão, embora considere a questão mais ampla, tendo em vista o movimento de desligamento precoce dos travestis da escola.

Através desse comentário Z. denuncia a Universidade como um espaço de reprodução das estruturas normativas da sociedade e de exclusão, indo de encontro a políticas amplas de ações afirmativas, defendidas pelo LGBT.

W. fala da sua vivência dentro do KIU!: [...] é aprendizado contínuo, ainda espero aprender muito, no contato com outras pessoas, criando junto, em espaços de atuação política! Atualmente, ele atua junto ao Partido dos Trabalhadores, no grupo que discute as questões ligadas aos direitos LGBT, o que mostra a articulação desses coletivos com partidos políticos de esquerda, item também caracterizado por Anjos (2000). 
As múltiplas conexões realizadas entre o KIU!, outros grupos de militância LGBT, partidos políticos e, na própria Faculdade, a interlocução com (poucos) professores simpatizantes da temática, mostram uma articulação complexa do grupo, sendo um exemplo efetivo de atuação política e de ocupação de espaços políticos possíveis pela juventude universitária. Suas intervenções dão-se, tanto através da promoção de discussões na universidade, através das Semanas LGBT e do Projeto Universidade Fora do Armário, quanto em espaços de representação política convencionais, dentro dos CA, DA e DCE e em partidos políticos. Movimentos externos de combate à homofobia, paradas e as Convenções municipais, estaduais e nacional LGBT, contam com sua participação efetiva.

V., estudante de Jornalismo de uma faculdade particular, relata sua trajetória em diferentes grupos universitários LGBT:

Em 2007, comecei participando do NUGSEX - DIADORIM, Núcleo de Estudos de Gênero e Sexualidade da UNEB. No mesmo ano, passei pelo Coletivo Cruéis Tentadores, que também tem uma pesquisa na área de Sexualidade e foi por onde conheci o Kiu!. No final do ano de 2007, fiquei sabendo do E-Jovem e comecei a participar dele. Agora, em 2008, estou militando pelo Kiu! e desenvolvendo propostas de novos grupos.

No período de um ano, tempo correspondente a sua entrada no curso de Jornalismo, ele transitou por quatro grupos distintos: o NUGSEX-Diadorim, o Coletivo Cruéis Tentadores, o E-Jovem e o Kiu!, além de relatar ter feito parte do movimento de criação do UNISEX, na FTC, quando da organização dos seus seminários. Ele fala das contribuições ao NUGSEX-Diadorim, em atividades internas dentro da UNEB, e dos projetos que pretende ajudar a realizar, como recém-ingresso no KIU! V. critica o que ele denomina de "politicagem", observada dentro de um dos grupos de que participou, e manifesta interesse em desenvolver atividades voltadas à pesquisa e à educação.

R. também participa do KIU! e afirma que a marca do grupo é a diversidade, que se dá tanto pela preocupação com os diversos segmentos 
do movimento estudantil e da população LGBT, quanto pela diversidade teórica que norteia o grupo, que vai desde o marxismo ao pós-estruturalismo da teoria Queer, que discute a normalização das identidades sexuais pautadas no binômio heterossexual/homossexual:

Nosso grupo se caracteriza pela diversidade, e é isso que nos agrega, temos vários olhares sobre o Movimento Estudantil, sobre a Conjuntura da Política Pública para a população GLBT, sobre a epistemologia da homossexualidade e das relações de gênero, a teoria Queer de Judith Butler. Os embates ideológicos e metodológicos são corriqueiros entre nós e por isso a nossa ação é diversificada, atendendo àquilo que nos propomos: discutir a Diversidade Sexual no âmbito da Educação e com a Juventude.

Nos dois grupos LGBT que forneceram depoimentos para a elaboração desse texto - o KIU! e o GGEBA -, a relação e a perspectiva de seus protagonistas, em diferentes contextos e com interlocutores variados, evidenciam a existência de fértil participação política de estudantes da UFBA nesses coletivos que se utilizam de meios diversos para viabilizar suas ações. Recursos tradicionais da arena política, reflexão teórica e científica sobre o fenômeno social, político e histórico da homoafetividade, intervenções estéticas que utilizam as artes plásticas e o cinema, a organização e a participação em eventos como festivais, seminários e paradas. Todas as possibilidades parecem boas para viabilizar os objetivos desses movimentos, dentro e fora do espaço universitário.

\section{DA JUVENTUDE E DA POLÍTICA: TENTANDO CONCLUIR}

O contato com os grupos e a coleta de informações indicam vários pontos importantes nas diferentes situações aqui tratadas. A vontade, mesmo prévia, de participar politicamente foi um ponto a considerar: o ambiente universitário não é o único responsável pelo desencadeamento da participação política de seus estudantes. Mesmo que, as escolas por que passaram, os estudantes não tenham como objetivo inserir 
gradualmente crianças e jovens no mundo das questões políticas, essa entrada se dá, ou essa sensibilização é feita, por diferentes agentes que vão da família, passando pelos grupos de iguais e pela mídia. É importante, inclusive, a julgar pelos relatos dos entrevistados, que as estratégias de proximidade sejam muito eficientes a esse respeito: pessoas com as quais os jovens mantêm vínculos afetivos e de confiança exercem um importante papel nesse engajamento. Em contrapartida, a vinculação a movimentos políticos e sociais interfere nos itinerários de vida e na constituição da subjetividade dos estudantes entrevistados, que se veem existencialmente vinculados aos movimentos que integram, $o$ que pode ser muito relevante em seus percursos acadêmicos e mesmo profissionais.

Outra questão a considerar é o rebatimento dessa participação, em grupos, entidades, movimentos e coletivos, na formação pessoal dos estudantes, no que eles chamam de modificação de identidade e percepção do mundo. A política tem o efeito de vincular os sujeitos às questões do seu mundo, do seu país, da sua comunidade proximal, apresentando caminhos e possibilidades de ação coletiva que podem fazer enorme diferença na formação integral de uma pessoa, sobretudo, jovens universitários, ávidos em encontrar seu lugar, em meio a dilemas identitários característicos dessa idade da vida.

Um alerta, entretanto, é feito: aquilo que sentem como desvalorização, pela instituição universitária, das práticas políticas, de qualquer coloração ou formato, não havendo integração entre as instâncias administrativas e os diferentes movimentos. De uma forma ou de outra, os estudantes que ouvimos preconizam outras práticas institucionais, que legitimem melhor suas atividades, superando o clima de confronto que, eventualmente, torna críticas essas relações. Não podemos deixar de dizer que, embora não tenhamos ouvido, de forma sistemática, os gestores e professores, existem opiniões nesse campo que também preconizam formas mais dialogadas de enfrentar as dificuldades que a vida universitária apresenta para parcela significativa dos estudantes. 
Apesar dessas dificuldades, todos reconhecem que a universidade concede espaço para a articulação independente de diferentes grupos. Há uma infraestrutura mínima, constituída pelos espaços legitimados para os DA, CA e DCE, cujo funcionamento é garantido administrativamente.

A articulação externa dos movimentos que convivem no interior da UFBA é outro ponto de destaque; sejam como pontos de apoio, de negociação, interlocução ou ações paralelas, os estudantes não restringem sua movimentação política aos muros da universidade, participando de ações coletivas, locais e nacionais, que reforçam seus movimentos específicos, tornando-se fontes de mais aprendizagem do ponto de vista de sua formação política. $O$ trânsito dos estudantes por outros contextos auxilia sua formação política, que se dá de maneira informal, marginal e prática, no seio da movimentação de indivíduos e grupos sociais diversos. Dessa forma, os espaços políticos instituídos no meio universitário acabam se tornando portas de entrada para os movimentos sociais tomarem contato com o mundo, por vezes difícil de penetrar, que é a universidade.

O pertencimento a grupos, como o LGBT, o Movimento pelo Passe Livre e o Movimento da Luta Antimanicomial, demonstram, ao menos no caso da UFBA, que diferentes segmentos da juventude continuam ativos politicamente e buscam formas inovadoras de atuação. Foi intencional procurarmos escutar esses coletivos, porque atribuímos à expressão "participação política" um espectro mais largo do que o usual, muitas vezes confinada à participação política partidária ou voltada exclusivamente às grandes questões nacionais ou, no ambiente acadêmico, a temas relacionados estritamente ao que se convencionou chamar de "movimento estudantil". Talvez seja o caso de nos referirmos a "movimentos estudantis", no plural, para que sejam contempladas as novas possibilidades de vida coletiva e ação política presentes no meio universitário. 


\section{REFERENNCIAS}

ANJOS, Gabriele dos. Identidade sexual e identidade de gênero: subversões e permanências. Sociologias, Porto Alegre, ano 2, n. 4, p. 274-305, 2000.

BRAGG, Marccelus. Arte homo e militância total, nasce o GGBA.

22 de dez. 2006. Disponível em: <http: www.espacogls.com.br/ noticias $/$ ?noticia $=1780>$. Acesso em: 27 abr. 2011.

CASTRO, M. Políticas Públicas por identidades e de ações afirmativas: acessando gênero e raça, na classe, focalizando juventudes. In: NOVAES, Regina; VANNUCHI, Paulo (Org.). Juventude e sociedade: trabalho, educação, cultura e participação. São Paulo: Instituto Cidadania; Editora Fundação Perseu Abramo, 2004.

ENRIQUEZ, Eugène. O homem do século XXI: sujeito autônomo ou indivíduo descartável. RAE electron., São Paulo, v. 5, n. 1, 2006.

LOURO, Guacira Lopes. Teoria Queer - uma política pós-identitária para a educação. Estudos Feministas, p. 541-553, 2001.

ORTEGA, F. Amizade em Tempos Sombrios. In: YUNES, E.; BINGEMER, M. C. Mulheres de Palavra. São Paulo: Edições Loyola, 2003.

PRADO, M. A. Psicologia política e ação coletiva: notas e reflexões acerca da compreensão do processo de formação identitária do “nós”. Revista Psicologia Política, v. 1, n. 1, p. 149-172, 2001.

RAMOS, S.; CARRARA, S. A constituição da problemática da violência contra homossexuais: a articulação entre ativismo e academia na elaboração de políticas públicas. Physis: Revista Saúde Coletiva, Rio de Janeiro, v.16, n. 2, p. 185-205, 2006. 


\title{
ACESSIBILIDADE E VIDA UNIVERSITÁRIA pontuações sobre a educação inclusiva
}

\author{
(6) \\ ARLETE CARVALHO DE FIGUEIREDO \\ CAMILA PEREIRA LISBOA \\ CIRO FREDERICO \\ GABRIELA COTRIM \\ JOANA PEREZ \\ JOSINEIDE VIEIRA ALVES \\ LETÍCIA SILVEIRA VASCONCELOS
}

LUZIA MASCARENHAS DE ALMEIDA

Não sei muito bem como explicar isso, mas, quando nos deslocamos, somos, de certa forma, desestruturados por esse movimento para: estamos ali e ao mesmo tempo não estamos ali porque já estamos indo para outro lugar, se entendem o que quero dizer.

Para parar de se desestruturar, é preciso parar de se mexer. Ou você se mexe e não está mais inteiro, ou você está inteiro e não pode se mexer. BARBERY, 2008, p. 39-40

\section{INTRODUÇÃO}

Nas últimas décadas, em todo o mundo, a questão da inclusão ganha espaço e força, constituindo-se, hoje, em um movimento, tanto social 
quanto político, que busca garantir às pessoas com deficiência o exercício amplo de seus direitos, tais como: o acesso à educação, a facilitação da mobilidade, o desenvolvimento e o acesso à tecnologia assistida, a inserção no mundo do trabalho e a possibilidade de desfrutar de bens culturais, entre outros.

No que diz respeito à educação, o Brasil, como política de Estado, optou pela Educação Inclusiva, estabelecendo-a como modelo a ser implementado, em detrimento da Educação Especial. Esta decisão está posta já na Constituição de 1988, em seu artigo 206, quando determina que o ensino seja ministrado, garantindo-se a igualdade de condições de acesso e de permanência na escola. Mais adiante, no artigo 208, estabelece que a escolarização seja feita, preferencialmente, nas classes regulares, ficando o poder público responsável por garantir o suporte necessário para viabilizar esse atendimento. (BRASIL, 1988)

Desde então, a legislação vem sendo construída em sintonia com o movimento mundial de discussão e elaboração de políticas que garantam a prática da Educação Inclusiva e muitas propostas vêm sendo experimentadas em todo o país. Experiências estas que não se pretendem conclusivas:

Todas as experiências são legítimas, expressam a história da educação no nosso país, suas contradições e singularidades, evidenciam que não existe um caminho pronto e que basta percorrê-lo, mas que, somente a partir da compreensão das necessidades presentes e da efetivação de políticas que resultem nas mudanças exigidas pela sociedade, poderá se concretizar, em cada município, a inclusão educacional. (MEC, 2006, p. 09)

A questão da democratização do acesso de crianças, jovens e adultos, em todos os níveis de ensino, bem como a discussão sobre suas reais condições de permanência está, hoje, na pauta do dia. Assim, a educação superior também tem passado por transformações estruturais importantes, como, por exemplo, a implantação do sistema de cotas para alunos de escolas públicas, negros e/ou com deficiências. Esse novo cenário exige esforços para garantir a permanência, com qualidade, 
desses segmentos nas universidades brasileiras. Afinal, como afirma Coulon (2008), "acessar o ensino superior não garante o acesso ao saber". Segundo esse autor, o primeiro desafio que a universidade apresenta aos recém-chegados é o de se tornar um estudante e disso depende a continuidade dos seus estudos e sucesso. $\mathrm{O}$ autor descreve três tempos sucessivos para a realização desta tarefa: "o tempo do estranhamento, o tempo da aprendizagem e o tempo da afiliação". Para o estudante com algum tipo de deficiência, o percurso até a afiliação apresentará dificuldades suplementares, devendo, portanto, contar com o suporte necessário para responder às novas demandas postas pela universidade.

No presente, ainda é reduzido, tanto o número de estudantes com deficiência na educação superior, quanto é igualmente escassa a produção de conhecimento sobre o tema. Acreditamos, contudo, que a consolidação da Educação Inclusiva, nos níveis de ensino que antecedem a universidade, resultará, espera-se, no ingresso de um número cada vez maior de alunos com necessidades especiais em cursos de graduação e pós-graduação, o que coloca, para gestores, professores e a comunidade acadêmica, a necessidade imperiosa de tratar de forma adequada o tema, tanto por respeito à legislação, quanto por questões humanitárias e de direito. Neste artigo, pretendemos tratar da inclusão e da acessibilidade destes alunos em cursos de graduação, descrevendo especificamente a realidade da Universidade Federal da Bahia - UFBA e tendo como foco a Faculdade de Filosofia e Ciências Humanas (FFCH). Antes de apresentarmos os dados coletados e analisados por alunos de graduação do curso de Psicologia desta mesma universidade, apresentamos um histórico breve da educação inclusiva e, mais especificamente, sobre o tema da acessibilidade.

\section{UM POUCO DA HISTÓRIA DA EDUCAÇÃO INCLUSIVA}

Desde a década de 90, a educação brasileira passa por mudanças nas suas políticas, com a redefinição de diretrizes e ações elaboradas pelo MEC, para os diversos níveis e modalidades de ensino, a exemplo dos 
Parâmetros Curriculares Nacionais (PCNs) e das Diretrizes Curriculares Nacionais (DCNs). (OLIVEIRA, 2007) Dentre essas mudanças, merece destaque a política de educação inclusiva que, desde 1993, ocupa espaço nas legislações e na formulação de metas para o ensino público e privado. Política essa referendada em documentos que resultam de encontros internacionais, como a Declaração Mundial sobre Educação para Todos (1990), a Declaração de Salamanca (1994) e a Declaração da Guatemala (1999).

O Brasil reafirmou o compromisso, expresso na Declaração Mundial sobre Educação para Todos, ao se tornar signatário da Declaração de Salamanca, dando visibilidade às questões relativas à inclusão e à exclusão na educação. Um grande avanço, que resulta desta Declaração, foi o de ter conceituado educação inclusiva como educação para todas as crianças, superando, assim, a ideia de que ela se restringia aos alunos com deficiências. Segundo esse documento, as escolas:

Devem acolher crianças com deficiências e crianças bem dotadas; crianças que vivem nas ruas e que trabalham; crianças de populações distantes ou nômades; crianças de minorias lingüísticas, étnicas ou culturais e crianças de outros grupos ou zonas desfavorecidos ou marginalizados. [...] No contexto desta Linha de Ação, a expressão "necessidades educativas especiais" refere-se a todas as crianças e jovens cujas necessidades decorrem de sua capacidade ou de suas dificuldades de aprendizagem. Muitas crianças experimentam dificuldades de aprendizagem e têm, portanto, necessidades educativas especiais em algum momento de sua escolarização. As escolas têm que encontrar a maneira de educar com êxito todas as crianças, inclusive as com deficiências graves. (UNESCO, 1994, p. 17)

A concepção de educação inclusiva contempla, dessa forma, atenção para as diferentes necessidades, decorrentes de condições econômicas, sociais, culturais e individuais dos alunos. $\mathrm{O}$ termo necessidades educacionais especiais (NEE) é frequentemente utilizado nos documentos oficiais, e coloca ênfase nas ações que a escola deve promover para responder às necessidades dos que a procuram, tomando distância 
do paradigma da integração que regeu a educação de pessoas com NEE até a década de 90. (FERRARI; SEKKEL, 2007) A integração localizava no sujeito o alvo da mudança, pois visava inserir os alunos com deficiências na escola regular, sem mudanças no currículo ou no trabalho pedagógico, ou seja, era a criança quem deveria adaptar-se às exigências da instituição de ensino. (MARTINS, 2001)

O pressuposto desse modelo era que o problema residia nas características das crianças:

Na medida em que centrava toda a sua argumentação na perspectiva da detecção mais precisa dessas características e no estabelecimento de critérios baseados nessa detecção para a incorporação ou não [delas] pelo ensino regular. (BUENO, 2001, p. 24)

Ao afirmar que as dificuldades estavam nas crianças, deixava-se implícita a ideia de que a escola estava dando conta de seus fins e que obter ou não sucesso acadêmico dependia exclusivamente do educando.

De acordo com o paradigma inclusivo, a inserção do aluno é mais radical, completa e sistemática. A escola deve se adaptar às particularidades dos alunos, para, assim, atender a todos. Nesse sentido, indica-se a necessidade de mudanças no currículo, na cultura organizacional da escola, nos modos de conceber e avaliar o ensino e a aprendizagem e, especialmente, nos modos de compreender e se relacionar com a diferença e a diversidade humanas.

Os desafios para a consolidação de uma política inclusiva para a educação brasileira atravessam todos os níveis educacionais e, mesmo a Universidade, não se encontra isenta. Dificuldades diversas também são experimentadas pelos alunos que se matriculam em instituições de ensino superior. Conforme Miranda (2007), para ocorrer o acesso e a permanência, na universidade, do aluno com necessidades educacionais especiais é necessário que, além de condições arquitetônicas, também sejam asseguradas adaptações curriculares e a contratação e formação de profissionais preparados. Dentre essas condições, destacamos a questão da acessibilidade, foco do nosso trabalho. 


\section{PARA ALÉM DA MOBILIDADE, A ACESSIBILIDADE}

Em nosso país, a acessibilidade passa a figurar no aparato legal, a partir de 1998, com o projeto de Lei 4767/98, indicando normas para promover a acessibilidade de pessoas com deficiência e mobilidade reduzida. (MANZINI, 2008) Interessante ressaltar que, como pontua esse autor, foi a educação superior o primeiro nível educacional a ser alvo de uma legislação específica, que condicionava o reconhecimento e credenciamento de cursos às condições de acessibilidade oferecidas pelas Instituições. Esta portaria ainda continua em vigor nos dias atuais.

A Lei no 10.098, promulgada em 19 de dezembro de 2000, traz normas para a supressão de barreiras e de obstáculos nas vias e espaços públicos, no mobiliário urbano, na construção e reforma de edifícios e nos meios de transporte e comunicação, promovendo a acessibilidade das pessoas com deficiência ou com mobilidade reduzida. Essa lei assim define o termo acessibilidade:

[...] possibilidade e condição de alcance para utilização, com segurança e autonomia, dos espaços, mobiliários e equipamentos urbanos, das edificações, dos transportes e dos sistemas e meios de comunicação, por pessoa portadora de deficiência ou com mobilidade reduzida. (BRASIL, 2000)

O decreto no 5.296, de dezembro de 2004, que regulamenta a lei citada anteriormente, no seu artigo 24, estabelece que:

Os estabelecimentos de ensino de qualquer nível, etapa ou modalidade, públicos ou privados, proporcionarão condições de acesso e utilização de todos os seus ambientes ou compartimentos para pessoas portadoras de deficiência ou com mobilidade reduzida, inclusive salas de aula, bibliotecas, auditórios, ginásios e instalações desportivas, laboratórios, áreas de lazer e sanitários. (BRASIL, 2004)

É importante lembrar que a acessibilidade não se refere apenas à eliminação das barreiras urbanísticas, arquitetônicas e de transporte. Trata igualmente da eliminação de barreiras nas comunicações e informa- 
ções, versando sobre a necessidade de remoção dos entraves à expressão e ao recebimento e compreensão de mensagens e informações. Segundo Michels (2002), o MEC tem sugerido às Instituições do Ensino Superior (IES) algumas ações no sentido de melhor atender às necessidades individuais dos universitários. Aqui, serão destacadas algumas delas.

Com relação à deficiência auditiva: flexibilização na correção das provas escritas, valorizando o conteúdo semântico; aprendizado da língua portuguesa, principalmente, na modalidade escrita (para o uso de vocabulário pertinente às matérias do curso em que o estudante estiver matriculado); materiais de informações aos professores, para que se esclareça a especificidade linguística dos surdos.

Para a deficiência visual: possibilidade de alternativas na forma de realização das provas: lida, transcrita em Braille, gravada em mp3 ou ampliada para o portador de visão subnormal; ampliação do tempo disponível para a realização das provas; impressora Braille acoplada ao computador; software de ampliação de tela; equipamento para a ampliação de textos para atendimento ao estudante com visão subnormal, tais como: lupas, réguas de leitura, scanner acoplado a computador.

E, finalmente, para alunos com deficiência física: eliminação de barreiras arquitetônicas para a circulação do estudante, permitindo o acesso aos espaços de uso coletivo; construção de rampas com corrimãos ou colocação de elevadores, facilitando a circulação de cadeira de rodas; adaptação de portas e banheiros com espaço suficiente para permitir o acesso de cadeira de rodas; colocação de barras de apoio nas paredes dos banheiros; instalação de lavabos, bebedouros, telefones públicos em altura acessível aos usuários de cadeira de rodas.

Entretanto, para compreendermos como se dá a inclusão do aluno com necessidades educacionais especiais numa Instituição de Ensino Superior, do ponto de vista da conceituação de acessibilidade aqui apresentada, nada melhor que escutar as vozes de atores que, em seu cotidiano, vivenciam os dilemas entre aparato legal e condições materiais e subjetivas oferecidas. 
Dois estudantes da UFBA com NEE foram entrevistados ${ }^{1}$ : J., um estudante cadeirante do $1^{\circ}$ semestre do curso de Ciências Sociais e L., uma estudante cega do $7^{\circ}$ semestre do curso de Psicologia. Para melhor identificar a movimentação institucional para cumprir os dispositivos legais e atender às necessidades de inclusão desses e de outros estudantes na condição NEE, foram entrevistados, ainda, alguns responsáveis por projetos de acessibilidade na UFBA: o arquiteto que era, em 2008, membro da Comissão de Planejamento Físico; a responsável pelo Comitê de Acessibilidade e coordenadora do Núcleo de Acessibilidade das Pessoas com Necessidades Especiais e a professora, então Coordenadora do Colegiado do curso de Psicologia, envolvida com a elaboração de estratégias pedagógicas de inclusão para L.

Como estratégia de pesquisa, além das entrevistas realizadas, foram mantidos diários de campo pela equipe envolvida na elaboração desse estudo, onde foram relatadas observações realizadas ao longo das entrevistas e do acompanhamento dos dois estudantes, em alguns trajetos comuns para eles, dentro e em torno dos espaços da faculdade que frequentavam.

A análise do material colhido nas entrevistas foi organizada em cinco blocos temáticos: quantos são e de que necessitam os estudantes com NEE da UFBA; o cotidiano dos estudantes com NEE na FFCH e seu entorno; balanço da acessibilidade na UFBA; o que pensam os estudantes com NEE sobre o acesso e a permanência na educação superior; as mudanças que idealizam os estudantes.

1 Importante esclarecer que os dados que informam esse texto, tanto aqueles relativos aos estudantes, quanto aos aspectos institucionais, foram coletados no $2^{\circ}$ semestre de 2008 , não tendo sido realizada nenhuma atualização das informações, para a elaboração final desse texto. 


\section{a. Quantos são e de que necessitam os estudantes com NEE da UFBA?}

A priori, para que projetos de mudanças visando à acessibilidade sejam desenvolvidos, parece óbvio que os gestores e técnicos responsáveis conheçam esse universo, não apenas do ponto de vista quantitativo, mas, igualmente, os diferentes tipos de necessidades especiais apresentadas por esse conjunto de estudantes. Essa foi, exatamente, a primeira grande dificuldade encontrada: informações seguras, ao menos sobre o total de alunos com deficiências matriculados na UFBA. Essas informações foram buscadas no Comitê de Acessibilidade para Pessoas com Deficiência, no GEINE - Grupo de Estudos e Pesquisa Educação Inclusiva e Necessidades Educacionais Especiais - que integra o Programa de Pós-Graduação em Educação, da Faculdade de Educação da UFBA, e no setor de Seleção da Universidade. Em nenhum desses espaços foi possível obter dados precisos sobre estudantes, ou até professores e funcionários com algum tipo de deficiência.

As informações obtidas eram contraditórias. Algumas das pessoas que foram contatadas afirmavam que esse número existia e que havia registros sobre quantas pessoas com deficiência se encontravam em cada unidade universitária, porém, os dados não foram fornecidos por nenhuma delas. Já em outros momentos, foi apresentada a justificativa de que os números existiam, mas que não era possível divulgá-los para não expor, ou proteger o aluno com deficiência, assim como se faz com os alunos ingressos pelas políticas de ações afirmativas. Sublinhamos que a não identificação do aluno com necessidades especiais para a comunidade que o acolhe, certamente dificulta o compartilhamento das responsabilidades institucionais relativas a esse segmento.

Conforme Mazzoni e Torres (2005), a não identificação de estudantes nessa condição, via Sistema de Informação Acadêmico, irá comprometer a eficiência de qualquer outro sistema de identificação que se projete para o controle de informações que dizem respeito a essa população específica. Na pesquisa realizada por estes autores, que investigam a percepção de alunos com deficiência visual em relação às barreiras 
existentes no ambiente universitário, dizia um dos estudantes entrevistados: Ninguém sabia da minha existência. Eu queria que já viesse na lista de chamada [a observação referente à deficiência]. (MAZZONI; TORRES, 2005) Igualmente para Manzini (2008, p. 287), "a falta de uma cultura de acessibilidade também permeia o ensino de alunos com deficiência na universidade, que, na maioria das vezes, não conta com um sistema de identificação e atendimento às necessidades desses alunos".

Os entrevistados, responsáveis pelos setores de acessibilidade na universidade, mencionaram que, futuramente, haveria um censo a respeito desse assunto. $\mathrm{Na}$ época em que foram coletados os dados dessa pesquisa, a definição do número de pessoas com deficiência na UFBA e dos tipos de deficiências que apresentavam nos pareceu apenas uma questão de inferências e suposições, o que questiona amplamente as medidas eventualmente em curso de execução.

\section{b. $\mathrm{O}$ cotidiano dos estudantes com NEE na FFCH e seu entorno}

Os encontros com J. ocorreram no próprio pátio da Faculdade. A busca por um local mais tranquilo para a entrevista, nos levou a uma das salas de aula sem batente na entrada, por sugestão do próprio estudante, já que entrar em salas onde esse detalhe não foi previsto prejudica sua independência como cadeirante.

Este fato, que antes pareceria um mero detalhe, nos levou a considerar que, praticamente, toda a estrutura física da FFCH/UFBA causa dependência para a locomoção de pessoas com necessidades semelhantes às de J. Dessa forma, fatores ambientais podem exercer uma notável influência sobre os níveis de atividade e participação das pessoas com deficiências, devido ao fato de que, nesses espaços, podem ser encontrados obstáculos físicos ou de outros tipos (MAZZONI; TORRES, 2005 ) que se tornam, se não impedidores, ao menos fortes dificultadores para a realização das atividades ordinárias dessas pessoas.

Com relação a L., foi planejado um acompanhamento de seu trajeto pela equipe, do momento em que ela descia do ônibus até a sua 
chegada na sala de aula. Neste percurso, tendo descido do ônibus, L. parou no limite da calçada e pediu ajuda para atravessar as duas pistas. Nesse local, não há semáforos ou faixa de pedestres para aqueles que se dirigem à FFCH/UFBA. A distância que separa o ponto de ônibus da faculdade é de cerca de oitocentos metros, trajeto que realiza, na maioria das vezes, sozinha.

Apesar de ser um caminho percorrido todos os dias por L., e, portanto, familiar, ele não é totalmente previsível, apresentando diferentes dificuldades para uma pessoa cega. Não há um corredor livre para pedestres, veículos são estacionados no passeio, bloqueando a passagem de pedestres. Nos passeios, existem ainda declives, buracos, pedras soltas, postes, galhos de plantas espinhosas plantados nos prédios ou casas e que alcançam os que caminham pela calçada, sendo necessário desviar deles para evitar eventuais ferimentos. As saídas de garagens também constituem uma dificuldade para pessoas com deficiência visual, sendo um grande perigo para elas; quando existe, a sinalização é feita por meio de luzes, não havendo sinais sonoros. A passagem por habitações com cães e animais soltos na rua provoca medo em L., não somente pelo fato dela não conseguir identificar se o animal está preso ou solto, mas por não possuir meios de se defender de um eventual ataque.

A caminhada é interrompida devido a uma chuva moderada. L. diz que, quando isso acontece, na falta de uma capa protetora, ela acelera o passo. Isso pode ser perigoso, pois o caminho molhado apresenta-se mais escorregadio e é percorrido com menor atenção por ela, tornando-a mais susceptível a obstáculos e algumas armadilhas. L. fala da necessidade de muita concentração e pouca conversa para se guiar através dos sons, do movimento das correntes de ar, do tato e da percepção da passagem do tempo.

De fato, frente ao portão de entrada da faculdade, L. percebeu sua proximidade. Tomando uma das duas entradas que levam até o pavilhão de aulas, ela preferiu ser guiada pela corrente de ar, pois, quando esta se desfaz, ela se localiza, sabendo que já está no interior do prédio. 
Neste dia, L. acabou por não conseguir chegar ao destino - a sala de aula - em sua primeira tentativa. Ela se desorientou por estar, ao mesmo tempo, conversando, tendo que retornar até um ponto conhecido do trajeto para rememorar o percurso. Nesse dia, L. precisou de $50 \mathrm{mi}$ nutos para alcançar a sala de aula, quando essa tarefa é possível realizar em 20 minutos por pessoas não cegas.

Na pesquisa realizada por Mazzoni e Torres (2005), foi igualmente constatado que estudantes de outras universidades brasileiras com deficiência visual também relatam dificuldades em seus deslocamentos em áreas urbanas, construídas sem planificação adequada, com manutenção insuficiente, ocupadas de forma desordenada e com espaços públicos utilizados de forma inadequada.

\section{c. Um breve balanço da acessibilidade na UFBA}

O trajeto referente ao entorno da FFCH é área de responsabilidade municipal. A partir do portão de entrada já nos encontramos sob jurisdição federal o que implica em outro tipo de organização e administração. Portanto, as dificuldades encontradas por estudantes com NEE, dentro das universidades, são de responsabilidade das prefeituras do campus que devem viabilizar projetos voltados para permitir a acessibilidade, sendo responsáveis pela manutenção dos prédios das diferentes unidades.

No caso do percurso realizado por L., existem diversas esferas de competência que devem atuar concomitantemente para que o caminho se torne acessível. Além da Prefeitura Municipal, responsável pelas calçadas e manutenção física das vias públicas, há a Superintendência de Trânsito e Transporte de Salvador (TRANSALVADOR), responsável pelo tráfego, e a Subsecretaria de Controle Urbano (SUCON), responsável pela ocupação indevida das áreas públicas e os próprios particulares, ao deixarem sacos de lixo espalhados e não podarem a vegetação de seus jardins.

Através das entrevistas realizadas com J. e L., estudantes diretamente implicados com a questão da acessibilidade, percebemos que 
a busca por viabilizá-la na universidade não está estagnada, encontrando-se em processo de implementação. Existem iniciativas sendo desenvolvidas, mas, como disse um dos entrevistados: "ainda há muito que fazer”. Existem unidades que ainda não são acessíveis fisicamente, como é o caso da Faculdade de Educação, onde não há rampas adequadas, segundo o padrão das normas técnicas. A biblioteca dessa unidade se situa no terceiro andar, não existem elevadores e não há, sequer, um sanitário acessível.

Mas não se pode deixar de reconhecer os avanços que vêm sendo atingidos no quesito acessibilidade pelas Instituições Federais de Ensino Superior (IFES). O governo federal tem financiado o Projeto Incluir, nas universidades de sua rede, voltado para a adequação de instalações e equipamentos, modificando, através de suas ações, as suas estruturas físicas. (MANZINI, 2008) Através desse projeto, muitas ações têm sido realizadas na UFBA, tais como a compra de elevadores e o suporte à criação do Núcleo de Acessibilidade das Pessoas com Necessidades Especiais. Este tem, como escopo central, a concentração de todos os esforços, demandas e políticas de acessibilidade dentro da instituição, o que não é incompatível com as comissões e iniciativas das diversas unidades da UFBA com o mesmo fim.

Por meio dos recursos para a implantação do Núcleo, foi comprada uma impressora Braille e três leitores de tela (Jaws). Seus integrantes concentram esforços agora para preparar material didático para o aluno com deficiência visual, no sentido de prover o estudante dos meios adequados para que ele realize, com sucesso, suas tarefas acadêmicas. Ainda não há uma normatização das práticas de professores e estruturas acadêmicas para viabilizar a adaptação de material de leitura e exames, mas caminha-se para essa estruturação. Enfatizamos que o Núcleo se encontrava em fase de organização, na época da pesquisa, e que, provavelmente, seus trabalhos devem ter avançado ao longo desses quase dois anos que separam o levantamento dos dados da elaboração deste texto. 


\section{d. O que pensam os estudantes com NEE sobre $o$ acesso e a permanência no ensino superior}

Ao pensar no acesso à universidade, quando ainda morava no interior do Estado, J. afirma que era como se ela estivesse no Japão. Somente quando veio para Salvador é que começou a vislumbrar a possibilidade de fazer uma graduação, a partir do olhar diferenciado - expressão utilizada por ele - das escolas daqui em relação à educação superior, o que foi um motivo de incentivo para sua decisão. A importância atribuída à universidade é central no caso de J., pois, ou uso a cabeça ou fico totalmente excluído da sociedade, já que ele, por sua condição corporal, não pode realizar atividades que envolvam investimento físico.

Perguntado se o exame vestibular havia sido realizado de forma acessível, J. responde que houve acessibilidade física ao local da prova, mas afirma não ter gostado do fato de terem sido colocadas todas as pessoas com deficiência juntas, numa mesma sala, fato recorrente em quase todos os concursos. Ele preferia não ter sido segregado no momento do vestibular, pois, na faculdade, todos estudam juntos. J. completa: [...] eu sempre estudei em escola normal, então eu sou acostumado assim. Eu acho que até pra vocês sentirem que existem pessoas como a gente, daquela forma, e que têm os mesmos valores e a mesma competência. Isso é legal [...].

Com relação ao vestibular, cabe ressaltar que, atualmente, a UFBA garante a realização das provas em condições especiais, no caso de deficiência. $\mathrm{O}$ candidato pode solicitar provas em Braile ou Libras; tem acesso garantido através de rampas, pode solicitar mobiliário específico, ou mesmo tempo adicional de prova, entre outras medidas que julgar necessárias para seu bom desempenho. No caso de deficiência auditiva, são disponibilizados professores especializados e intérpretes nos dias de execução das provas discursivas e de redação, para garantir a compreensão das instruções. Além disso, a deficiência auditiva vem indicada nas provas discursivas, que serão corrigidas por professores especializados, de modo que as diferenças linguísticas sejam consideradas no momento da correção, privilegiando-se o aspecto semântico ao invés do estrutural. 
Já na faculdade, J. sente-se bem acolhido pelos professores e colegas. Alguns deles, que fazem parte do Diretório Acadêmico, representam J. junto à direção da faculdade. Ação crucial para que alguns horários de aulas fossem repensados - é comum, nos primeiros semestres, ocorrerem aulas em diversos campi diferentes, em horários próximos. Isso torna difícil o deslocamento dos alunos e, principalmente de J., que depende da qualidade da acessibilidade disponibilizada no trajeto que deve percorrer para atingir cada uma das salas de aula. Ele cita o exemplo do portão, que dá passagem à escola de Geociências, onde há barras que impedem a passagem da cadeira de rodas, e de um portão lateral, habitualmente trancado, o que implicava, para que J. entrasse, ser necessário que alguém suspendesse sua cadeira de rodas. Um ponto positivo citado por J. foi a reforma do banheiro da $\mathrm{FFCH}$, que agora inclui instalações para deficientes.

As barreiras interpostas a esse segmento de estudantes apontam para a reduzida independência por eles vivenciada na Universidade. Se retomarmos o conceito de afiliação, de Coulon (2008), vamos entender o quanto fatores como independência e autonomia são centrais para que os novos universitários realmente se integrem à vida acadêmica, escapando do insucesso.

Quanto ao processo seletivo experimentado por L. em seu ingresso, ela informa que, no vestibular, a pessoa cega geralmente tem duas possibilidades: fazer a prova em Braille ou fazê-la junto a um ledor. Algumas faculdades oferecem a possibilidade de a pessoa fazer a prova no computador, mas esse não foi o caso na UFBA. Ela optou por fazer a prova em Braille, já estando acostumada a esse sistema de escrita.

Na universidade, L. não se sente discriminada, tendo uma boa relação com os colegas e professores. A única coisa difícil é quando alguém desavisado leva um filme legendado para a sala de aula, porque isso a impede de participar da atividade proposta, o que acontece com outros recursos visuais que, se não descritos verbalmente, prejudicam sua compreensão. Mas L. mostra ser compreensiva quanto a essas situações, que envolvem colegas e professores, pois, segundo ela, as pessoas 
ainda não sabem lidar muito bem com alunos com algum tipo de necessidade especial.

Com relação às dificuldades encontradas para sua integração na universidade, L. queixou-se da inexistência de um núcleo de produção de materiais didáticos e da falta de uma estrutura física adequada e acessível no campus de São Lázaro (FFCH). Estas dificuldades foram superadas apenas parcialmente, devido tanto ao auxílio de alguns voluntários da Biblioteca Central, que realizavam gravações para ela de textos indicados pelos professores, quanto pela ajuda de colegas de turma, que também se ofereciam para auxiliá-la e de alguns professores que disponibilizavam os textos selecionados para serem previamente lidos ou digitalizados.

Quanto a este último aspecto, só depois de algum tempo, L. comprou, com recursos próprios, um scanner. O chefe do Departamento de Psicologia, na época, conseguiu também um scanner e uma impressora Braille, disponibilizando esses equipamentos para uso de L., na faculdade. Ainda como auxílio institucional, a coordenadora do Colegiado de Psicologia apresentou projeto ao Programa Permanecer, da Pró-Reitoria de Assistência Estudantil da UFBA, exclusivamente voltado para a acessibilidade e a inclusão de L. Com isso, dois bolsistas passaram a ser responsáveis por escanear os textos necessários ao seu bom desempenho acadêmico. Além disso, L. passou a contar com um computador dotado de programa específico, para o preparo de atividades acadêmicas e acesso à internet.

É importante observar que os dois estudantes se referem a uma acessibilidade favorecida por iniciativas particulares - no caso de J., proporcionada por colegas do D.A. e por aqueles que o auxiliam nos deslocamentos pelos campi e, no caso de L., por alguns professores, colegas e funcionários voluntários. Se a concorrência da solidariedade da comunidade universitária pode ser considerada como importante fator para a integração plena dos estudantes NEE na educação superior, é fato que o aparato institucional necessita evoluir e se consolidar na forma de rotinas que sejam disponibilizadas sem a necessidade de demandas repetidas por parte desse segmento. 


\section{e. As mudanças que idealizam os estudantes}

Perguntado sobre o que seria preciso para remover as dificuldades de acessibilidade citadas por ele, J. fala sobre uma espécie de reforma geral em todo o campus da UFBA:

Em todos os lugares que eu vou, o piso tá quebrado, a rampa é mal feita... É feita assim, com quase noventa graus de inclinação! Tem lá no PAF, umas rampas assim, que parece que a escada é pro céu, não é pra subir... Jamais eu consigo subir sozinho, jamais! Então é isso, a acessibilidade pensada por pessoas que tenham conhecimento daquilo. E também essa questão dessa escada que vai dar lá no PAF [...] Deveria ter umas rampas inclinadas, elevadores... Algo que sirva não só pra gente, mas pra vocês também. Algo que seja inclusivo, fazer o bem pra os outros também, não só pra mim. Embora eu seja uma pessoa que tenha limitações, mas vocês têm também limitações, cansaço... É claro que tem coisa que gente como eu, L. [...] precisa com maior urgência. Se uma calçada tá com buraco, vocês passam por cima e tá tudo bem. Mas pra mim, por exemplo, não dá pra passar por cima, cai ali, fica até morto [...].

J. acrescenta que é necessário que todos percebam a acessibilidade como algo comum, parte do cotidiano, substituindo a espécie de "viseira" de grande parte das pessoas, por não apresentarem as mesmas dificuldades de locomoção ou acesso que as pessoas que apresentam algum tipo de deficiência. É preciso mudança de mentalidades, do senso comum, em paralelo à materialização de políticas governamentais eficazes.

No que se refere à universidade, J. diz que, ainda, as mudanças que ele observa resultam de atitudes individuais de colegas e alguns professores sensíveis às necessidades da pessoa com deficiência e, assim, mobilizam-se, não apenas para auxiliar diretamente como também para fazer cobranças à instituição. Porém, ele vê como necessário um olhar mais abrangente, resultando numa política de acessibilidade global para a universidade, algo que partisse da administração central e outros responsáveis. 
Em relação ao curso de Psicologia, L. faz questionamentos quanto à sua prática no campo, citando um evento ocorrido nas práticas da disciplina Psicopatologia III, no Hospital das Clínicas:

Atendi quatro vezes um senhor. A experiência foi bem interessante e, confesso, um tanto desconfortante, porque ainda não sei como proceder. Falo isso um pouco pela minha inexperiência mesmo enquanto estudante, mas também enquanto pessoa cega. Ocorreram algumas situações que tive dificuldades em lidar, como por exemplo, quando ele me perguntou pela minha cegueira e quando quis me acompanhar até o elevador. Nessa situação, questionava-me o porquê dele agir assim, queria apenas ser gentil ou percebeu que eu poderia ter dificuldades no trajeto até o elevador? Será que o fato dele me ajudar poderia atrapalhar o processo transferencial? Vários grilos passaram por minha cabeça. Ainda não sei lidar com essas questões. Na minha supervisão, fui levada a pensar se, realmente, me aceitava enquanto pessoa cega. Sinceramente, acredito que sim. Nunca tive problemas com isso. Sempre me vi brincando, fazendo graça das minhas questões. Mas percebo a importância de ter autonomia naquilo que faço, no local que trabalho, enfim. Isso será bom pra mim e para a pessoa que estou atendendo, porque teremos mais segurança. Ainda não fiz um reconhecimento completo do Hospital das Clínicas. Isso é importante para que tenha uma boa locomoção no espaço. $\mathrm{Na}$ entrada, por exemplo, parece-me um local bem aberto, não sei me orientar direito ainda $[. .$.$] .$

Esse trecho do relato de L. nos faz pensar em outras dimensões da inclusão que ultrapassam as urgentes mudanças relativas à acessibilidade dos campi e instalações da UFBA. De fato, é necessário que os componentes curriculares dos cursos oferecidos pela universidade sejam analisados e criadas as condições para garantir o pleno desenvolvimento de estudantes que apresentem algum tipo de deficiência. No caso de L., especificamente, urge elaborar estratégias inovadoras de observação e intervenção, que dispensem o uso da visão e que ela possa contar com apoio e orientação acadêmica para encaminhar os 
novos problemas que se colocam em sua formação para a profissão que escolheu. Esse se constitui num grande desafio, que pode obter grandes contribuições de estudantes, professores e profissionais que estejam dispostos a repensar suas práticas, elaborando alternativas efetivamente inclusivas no meio acadêmico.

\section{CONCLUSÕES}

Com base nas entrevistas realizadas com os estudantes e com responsáveis por órgãos de acessibilidade da Universidade, percebemos que o projeto institucional de acessibilidade e inclusão da pessoa com NEE, ainda está nos seus primeiros passos, mas que a instituição busca, de forma interessada, adequar-se para cumprir as determinações legais e auxiliar, efetivamente, a inclusão de estudantes com NEE. No Brasil, as pessoas com deficiência representam uma parcela significativa da população. Segundo o censo do IBGE - Instituto Brasileiro de Geografia e Estatística, realizado em 2000, 14,5\% da população brasileira possuem algum tipo de deficiência. Este número é ainda maior na região Nordeste, chegando a $16,8 \%$ da população; no caso específico de deficientes visuais, a Bahia é o Estado brasileiro com o segundo maior número absoluto: 15.400 pessoas.

Os dados demonstram que, à medida que se considera um tempo maior de escolarização, a proporção de pessoas com deficiência diminui, sendo de uma para cada três pessoas sem deficiência com até três anos de escolarização, mas apenas uma para cada dez, quando se considera o ensino fundamental incompleto ou oito anos de estudo. O censo não traz dados acerca do número de pessoas com deficiência que frequentam ou frequentaram a educação superior, mas a prática mostra que este número é ainda pouco significativo no conjunto da população total de estudantes nesse nível de ensino.

O incentivo à escolarização das crianças e jovens com algum tipo de NEE, apoiado pelos avanços na legislação específica de proteção e promoção da qualidade de vida desses brasileiros, deve incrementar, 
nos próximos anos, a sua busca pela educação superior, como um dos fatores decisivos de sua completa inclusão social. Mas, como para outros setores da população, facilitar o acesso é apenas parte de uma dívida com a democracia e a equidade que o país apenas inicia a honrar. Permanência com qualidade e orientação para o conjunto da comunidade universitária são tarefas gêmeas das providências relativas ao acesso.

Embora muito se tenha produzido sobre inclusão escolar, há pouca literatura que trate deste tema no contexto universitário. Aqui apresentamos, em caráter exploratório, circunscrito ao contexto específico da UFBA, algumas notas e reflexões em torno do tema que, esperamos, contribuam para que outros estudos tomem a universidade como contexto para a discussão da inclusão e acessibilidade de jovens com NEE. O caminho ainda a percorrer é longo e, como bem disseram J. e L., cheio de obstáculos.

\section{REFERÊNCIAS}

BARBERY, Muriel. A Elegância do Ouriço. São Paulo: Companhia das Letras, 2008.

BRASIL. Constituição da República Federativa do Brasil. 18. ed. São Paulo, SP: Saraiva, 1988. Promulgada em 05 de outubro de 1988.

BRASIL. Lei 10.098 de 19 de dezembro de 2000. Brasília, 2000. Disponível em: <http://www.planalto.gov.br/CCIVIL/LEIS/L10098.htm> Acesso em: 16 fev. 2010.

BRASIL. Decreto de Lei No 5.296 de 02 de dezembro de 2004. Brasília, 2004. Disponível em: <http://www.planalto.gov.br/ccivil/_ato2004-2006/2004/ Decreto/D5296.htm> Acesso em: 25 fev. 2010.

BUENO, J. G. S. A inclusão de alunos deficientes nas classes comuns do ensino regular. Temas sobre Desenvolvimento, v. 9, n. 54, p. 21-27, 2001.

COULON, Alain. A condição de estudante: a entrada na vida universitária. Tradução de Georgina dos Santos e Sônia Sampaio. Salvador: EDUFBA, 2008. 
DECLARAÇÃO DA GUATEMALA. Convenção Interamericana para a eliminação de todas as formas de discriminação contra as pessoas portadoras de deficiência. Guatemala, 1999.

FERRARI, Marian A. L.; SEKKEL, Marie Claire. Educação inclusiva no ensino superior: um novo desafio. Psicologia Ciência e Profissão, v. 27, n. 4, p. 636-647, 2007.

INSTITUTO BRASILEIRO DE GEOGRAFIA E ESTATÍSTICA. Banco Multidimensional de Estatísticas (BME) - Censo. 2000. Disponível em: <http:// www.ibge.gov.br/home/> Acesso em: 22 fev. 2010.

MANZINI, E. J. Acessibilidade: um aporte na legislação para o aprofundamento do tema na área de educação. In: BAPTISTA, C. R.; CAIADO, K. R. M.; JESUS, D. M. de (Org.). Educação especial: diálogo e pluralidade. Porto Alegre: Mediação, 2008.

MARTINS, L. A. R. Por uma escola aberta às necessidades do aluno. Temas sobre Desenvolvimento, v. 10, n. 55, p.28-34, 2001.

MAZZONI, A. A. A.; TORRES, E. F. A percepção dos alunos com deficiência visual acerca das barreiras existentes no ambiente universitário e seu entorno. Benjamin Constant, ano 11, n. 30, p. 10-17, 2005. Disponível em: <www.inf.ufsc.br/jbosco/IEE/publicações.html> Acesso em: 10 jul. 2007.

MINISTÉRIO DA EDUCAÇÃO. Apresentação. In: ROTH, B. W. (Org). Experiências educacionais inclusivas - Programa educação inclusiva: direito à diversidade. Brasília: Ministério da Educação, Secretaria de Educação Especial, 2006.

MICHELS, L. R. Acesso e permanência do educando portador de necessidades especiais na instituição de Ensino Superior. Rede SACI, São Paulo, 2002. Disponível em: < http://saci.org.br/index.php?modulo=akemi \&parametro=2933>. Acesso em: 10 jul. 2007.

MIRANDA, T. G. A inclusão de pessoas com deficiência na universidade. In: JESUS, D. M. de. et al. Inclusão, práticas pedagógicas e trajetórias de pesquisa. Porto Alegre: Mediação, 2007.

OLIVEIRA, I. A. de. Política de educação inclusiva nas escolas: trajetória de conflitos. In: JESUS, D. M. de. et al. Inclusão, práticas pedagógicas e trajetórias de pesquisa. Porto Alegre: Mediação, 2007. 
ORGANIZAÇÃO DAS NAÇÕES UNIDAS PARA A EDUACAÇÃO, A CIÊNCIA E A CULTURA. Declaração de Salamanca e linha de ação sobre necessidades educativas especiais. Brasília: CORDE, 1994.

UNESCO - Declaração mundial sobre educação para todos e plano de ação para satisfazer as necessidades básicas de aprendizagem. Jomtien, Tailândia: 1990. 


\section{TREINAMENTO EM HABILIDADES SOCIAIS uma ferramenta útil para atuar em ações afirmativas?}

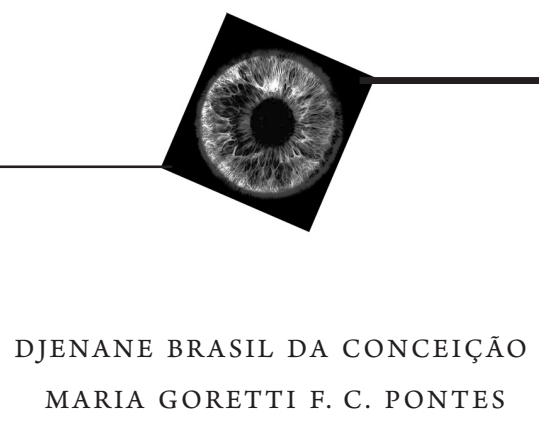

RELEMBRANDO ASPECTOS DA HISTÓRIA DO BRASIL

A escravidão negra foi um dos eventos históricos mais marcantes da trajetória do Brasil na direção de tornar-se um país. Pessoas negras foram expropriadas de sua humanidade, tratadas como mercadorias, sequestradas de suas terras de origem e trazidas para desenvolverem o duro labor escravo. Transportadas e mantidas em condições subumanas, experimentaram todas as formas da violência: física, moral, religiosa e simbólica. A violência, assim, atuava como estratégia de dominação e de controle social dos senhores de terras sobre os negros escravizados.

Campos (2005) afirma que a escravidão no Brasil passou por dois períodos: o primeiro, de 1550 a 1850, e o segundo, de 1850 até a abolição. No primeiro período:

A luta e a resistência dos escravos contra o instituto da escravidão se deram de forma ativa e solitária, sem auxílio de 
nenhum grupo social. Nesta primeira fase do escravismo, é que tivemos as grandes insurgências dos escravos negros. (CAMPOS, 2005, p. 27)

É desse período que datam a formação de quilombos e o crescimento da violência de escravos contra famílias de fazendeiros, inclusive com o registro de homicídios. Já no segundo período, a luta dos escravos deu-se de forma diferenciada, sendo caracterizada por alianças com grupos abolicionistas, numa espécie de "resistência passiva" e através da formação de grupos religiosos, associativos ou voltados para o lazer (batuque, dança, música, capoeira etc.), um mundo secreto vivido no interior das senzalas.

Essa situação de conflito social perdurou até 1888, ano oficial e formal da Abolição da Escravatura. Como é largamente conhecida, mesmo após o 13 de maio de 1888, a situação de marginalização dos negros e afrodescendentes pouco mudou em termos de suas condições de vida, extremamente desfavoráveis. Para justificar as profundas desigualdades submetidas a essa população, agora "liberta", importa-se o Eugenismo - ou a Teoria de Purificação das Raças - presente no ideário de muitos intelectuais e pessoas proeminentes. Elas acreditavam que o Brasil, para se desenvolver, precisaria “embranquecer". (BENTO, 2002)

Nos anos que se seguiram à abolição, a Proclamação da República (1889) e a Assembleia Constituinte (1891) contribuíram para a instauração do Estado burguês no Brasil, onde todos os homens foram igualados, formalmente, perante a lei. Entretanto, essas mudanças ainda não resultaram na adoção de medidas de inclusão da população negra, recém-liberta, à sociedade. Ao contrário, registrou-se o desenvolvimento das teses do branqueamento, com o objetivo de "melhorar" a população brasileira e a formulação e implementação de ações e políticas de modo a impedir a ascensão social do negro, como foi o caso do favorecimento à entrada de imigrantes europeus no Brasil e restrições quanto à imigração de outros povos. (CAMPOS, 2005) Adicionalmente, “[...] a criação de uma classe intermediária, que muitos pesquisadores 
denominarão de 'mulatos', foi uma das estratégias dominantes contra a tomada de consciência das 'populações de cor"' (MOURA, 1998 apud CAMPOS, 2005, p. 42), criando uma categoria populacional "menos negra”, e, portanto, a caminho do embranquecimento como meta.

Aliando-se a esses fatores, criou-se em nosso país o "mito da democracia racial" que acabou por atuar como estratégia de ocultação da discriminação direcionada às pessoas negras. "A idéia de democracia racial acabou sendo um recurso inicial para que não se enfrentassem os problemas decorrentes da destituição do escravo e da espoliação final de que foi vítima." (CAMPOS, 2005, p. 48) Este mito continua a ser um dos fatores que contribui para a manutenção do quadro de desigualdades e exclusão em nosso país. Poucas pessoas admitem que há discriminação racial no Brasil, embora muitas a vivenciem cotidianamente. Segundo Ferreira (2002, p.71):

[...] no Brasil, o preconceito não é abertamente afirmado, dificultando a elaboração de leis que favoreçam sua reversão. A ideologia de que vivemos num país em que as diferenças são aceitas e valorizadas, 'um verdadeiro exemplo para outras nações', encobre o problema.

De caráter ideológico ${ }^{1}$, político e social, estabeleceram-se as categorias sociais de "negro" e "branco" no Brasil. Ao transformar questões ideológicas, políticas e sociais em explicações de caráter biológico e naturalista, como a cor da pele, o tipo de cabelo, o formato das nádegas ou a configuração da boca e nariz, os segmentos hegemônicos justificaram, e ainda justificam, as injustiças sociais que se perpetuam desde a escravidão. Através de inúmeras estratégias de inferiorização e de desqualificação, os indivíduos negros e afrodescendentes foram mantidos secularmente à margem da sociedade o que, possivelmente, levou indivíduos submetidos a essa condição, ou a eles solidários, a indagar: "O que fazer para reverter esse quadro?" "Como promover a inclusão

1 Ideologia aqui compreendida como estratégias que são usadas por grupos ou pessoas para dominar, exercer poder de modo desigual, assimétrico, sobre outras. (LANE, 1995) 
social de grupos minoritários?" "Que ações ou medidas conduziriam a uma sociedade mais justa e igualitária?” Diversas respostas foram encontradas por diferentes movimentos sociais, no Brasil e no mundo.

No caso do Brasil, é importante citar o papel do Movimento Negro Unificado (MNU) que, no final da década de 80 do século $\mathrm{XX}$, chamava a atenção para algumas contradições da democratização brasileira:

A partir de então, o MNU propõe uma série de medidas de compensação e reparação pelas perdas sofridas durante 400 anos de hegemonia racial, apoiadas em estudos estatísticos que revelarão a situação do negro brasileiro. (SISS, 2003 apud CAMPOS, 2005, p. 79)

Destaca-se também a III Conferência Mundial das Nações Unidas de Combate ao Racismo, Discriminação Racial, Xenofobia e Intolerância Correlata, realizada na cidade de Durban, África do Sul, de 31 de agosto a 08 de setembro de 2001. Os países participantes, dentre eles o Brasil, assinaram um documento final, contendo diretrizes para a construção de políticas públicas específicas para a inclusão social das populações suscetíveis àquelas formas de subordinação social. Desde então, o Brasil comprometeu-se internacionalmente a "promover programas e ações que sejam de fato includentes para as comunidades excluídas 'sócio-racialmente'”. (CARVALHO, 2004 apud CAMPOS, 2005)

Assim, entre nós, ocorreram diferentes formas de organização e manifestação em favor dos direitos das populações negras. Consideramos que as ações afirmativas, certamente, são resultados dessas mobilizações sociais, interessando-nos, agora, apresentar algo sobre seu histórico e formulação.

\section{AÇÕES AFIRMATIVAS, COTAS E O CONTEXTO DAS UNIVERSIDADES PÚBLICAS BRASILEIRAS}

As ações afirmativas vêm sendo implementadas em diferentes países do mundo, desde 1948, embora a expressão ação afirmativa, propriamen- 
te dita, tenha sido cunhada nos Estados Unidos da América, na década de 60 do século XX. Caracterizam-se por medidas compensatórias aplicadas a grupos minoritários ${ }^{2}$ que sofreram processos históricos de discriminação e/ou de exclusão. Enquanto a legislação antidiscriminatória brasileira, com a instituição do crime de racismo como inafiançável e imprescritível, possui caráter proibitivo e punitivo de atitudes de discriminação racial e é voltada para a dimensão individual, as ações afirmativas têm um caráter de discriminação positiva e visam instituir, socialmente, a igualdade de fato ou igualdade substantiva, sendo direcionadas para os níveis institucionais, públicos ou privados, em que a discriminação se manifesta, ou seja, são de caráter coletivo. As ações afirmativas podem aparecer como políticas públicas ou ações da iniciativa privada que contribuem para a redução das desigualdades sociais. Segundo o MEC - Secreteria de Educação Continuada, Alfabetização e Diversidade (SECAD) (2007):

[...] as ações afirmativas constituem um conjunto de políticas públicas e privadas, que podem ser obrigatórias, facultativas ou mesmo voluntárias. São voltadas para grupos sociais que foram alvo de processos históricos de discriminação (por cor ou raça, gênero, orientação sexual, etnia, deficiência física, origem nacional, filiação religiosa etc.). Sua concepção objetiva o combate às discriminações sofridas por estes grupos e, ao mesmo tempo, a redução ou correção do efeito das discriminações desenvolvidas no passado ou no presente. O objetivo mais amplo da ação afirmativa é viabilizar a concretização do ideal de igualdade de acesso a bens sociais fundamentais como educação, emprego, saúde etc.

Dessa forma, as ações afirmativas relacionam-se a reparações e compensações por prejuízos, reais ou simbólicos, sofridos por grupos discriminados e/ou excluídos, visando fomentar a sua inclusão social em todos os níveis sociais. De acordo com Campos (2005, p. 62, grifo nosso):

2 Minoritários significa com menor poder ou prestígio, o que não necessariamente indica um menor número de pessoas. 
As Ações Afirmativas são medidas especiais e temporárias que conduzem à compensação de determinados segmentos da sociedade, neste caso os negros e seus descendentes, por motivo de discriminação e marginalização a que foram submetidos no passado e incluem a implementação de programas de diversidade nas empresas, suporte a programas educacionais, oportunidade de emprego no serviço público e privado, entre outros. Por possuírem um caráter reparatório, as Políticas de Ação Afirmativa não são eternas. Elas possuem um tempo determinado de duração, estendendo-se até a eliminação, correção e equalização das desigualdades.

Conforme Silva (2004, p. 39), o conceito de ação afirmativa viabiliza:

O princípio da dignidade da pessoa humana que exige uma igualdade em sentido axiológico-jurídico material [...] têm por objetivo estabelecer critérios de diferenciação para se compensar a desigualdade factual de oportunidades, promovendo a superação de obstáculos.

Frequentemente, os processos de discriminação e/ou de exclusão podem ser facilmente aferidos pelas diferenças no desempenho social, quando se comparam os grupos de pessoas discriminadas e não discriminadas. Um caso particular dessas diferenças é a relação desproporcional entre o número de negros e afrodescendentes e o número de brancos, que é grande, no que diz respeito ao acesso às universidades públicas. Inicialmente, como produto da articulação dos movimentos sociais, em especial dos movimentos negros, houve a criação dos prévestibulares para negros e carentes (PVNC) ou pré-vestibulares comunitários, donde se destacam o oferecido pela Fundação Instituto Steve Biko, em Salvador, e o Educafro, de Frei David, no Rio de Janeiro. Por ocasião dos seminários preparatórios para a III Conferência em Durban, a adoção de cotas nas diversas instâncias sociais e nas universidades públicas, em especial, emerge dentre outras propostas de ações afirmativas. (CAMPOS, 2005) 
O sistema de reserva de vagas, denominado "cotas", é uma forma particular de ação afirmativa. Seu principal objetivo é promover a equiparação de oportunidades, para ingresso em diferentes instituições, dos grupos tradicionalmente delas excluídos. Esta ação afirmativa precisa vir acompanhada de outras, que garantam a concretização do princípio da igualdade (de fato) com relação à diversidade. No que diz respeito ao ingresso de pessoas negras na universidade pública brasileira, as cotas têm se destacado dentre as ações afirmativas propostas, mas há outras ações afirmativas adotadas por algumas universidades, como o sistema de pontos (UNICAMP) e o percentual adicional (USP). Entende-se que programas de acesso como: isenção de taxa de vestibular, cotas, pontos adicionais, percentual adicional, pré-vestibular comunitário assim como os programas de permanência e de pós-permanência, nas universidades públicas, são todos eles necessários e complementares.

É importante salientar que, se o objetivo das ações afirmativas é promover a inclusão social, um dos principais parâmetros de eficácia de uma ação afirmativa, para acesso ao ensino superior, deve ser o número de ingressantes, ou seja, a quantidade de estudantes que ela leva para a universidade. Os indicadores seguintes seriam o número de estudantes que efetivamente se formam e, o número destes que efetivamente encontram espaço no mundo do trabalho, conforme sua formação, e/ou é aceito em programas de pós-graduação, se decidem seguir a carreira acadêmica ou melhorar sua qualificação em programas do tipo "profissional".

Segundo Ferreira e Andrade (2006), existiam, na época, no Brasil, 24 instituições públicas de ensino superior que adotaram ações afirmativas para negros e afrodescendentes, sendo que 21 delas adotaram o sistema de reserva de vagas. Dentre essas, 14 universidades adotaram como requisitos para concorrer ao sistema de cotas ser negro e oriundo de escola pública; 6 adotaram como requisito ser negro e um critério socioeconômico e 4 universidades adotaram como requisito para concorrer ao sistema de cotas apenas ser negro. Uma única universidade, a Universidade Federal de Alagoas (UFAL), tem um percentual destinado a mulheres negras. A maioria delas adota a autodeclaração 
como forma de identificação dos candidatos. Todas as regiões do Brasil possuem ao menos uma universidade que adotou uma forma de ação afirmativa. No Nordeste, em 2006, eram quatro universidades: UNEB, UFBA, UFRB e UFAL. Analisaremos, doravante, o caso da UFRB instituição a que pertencemos.

\section{A UFRB, A PROPAAE E AS AÇÕES AFIRMATIVAS}

A Universidade Federal do Recôncavo da Bahia - UFRB foi criada pela Lei 11.151, de 29 de julho de 2005, por desmembramento da Escola de Agronomia da Universidade Federal da Bahia - UFBA, com sede e foro na Cidade de Cruz das Almas e unidades instaladas, atualmente, em Amargosa, Cachoeira e Santo Antonio de Jesus. A UFRB é, portanto, uma universidade multicampi, com autonomia administrativa, patrimonial, financeira e didático-pedagógica (UFRB).

O modelo multicampi da UFRB tem como objetivo principal explorar o potencial socioambiental de diferentes espaços do Recôncavo Baiano, bem como servir de polo integrador para essa região, tendo como base de sustentação alguns princípios, tais como: cooperação com o desenvolvimento socioeconômico, científico, tecnológico, cultural e artístico do Estado e do País; compromisso com o desenvolvimento regional; criação de marcos de reconhecimento social, oriundos dos serviços especiais prestados no atendimento da população e a adoção de políticas afirmativas de inclusão social, dentre outros. No que concerne à adoção de políticas afirmativas, o ato de criação dessa nova universidade já contemplava o sistema de cotas, constituindo-se, a UFRB, na primeira universidade pública brasileira a possuir uma PróReitoria de Políticas Afirmativas e Assuntos Estudantis (PROPAAE), o que fala por si da dimensão alcançada pelas ações afirmativas e pela atenção aos estudantes nesta universidade.

A PROPAAE tem como missão:

Assegurar a execução de políticas afirmativas e estudantis na UFRB, garantindo à comunidade acadêmica condições 
básicas para o desenvolvimento de suas potencialidades, visando a inserção cidadã, cooperativa, propositiva e solidária nos âmbitos cultural, político e econômico da sociedade ${ }^{3}$.

Esta Pró-Reitoria interage com outras instâncias universitárias, tanto internas quanto externas, bem como com outras instituições, para garantir a execução de seus objetivos de acordo com sua missão:

A PROPAAE foi criada com o propósito de articular, formular e implementar políticas e práticas de democratização relativas ao acesso ao ensino superior, permanência dos alunos na Universidade e pós-permanência estudantil, de forma dialógica e articulada com os vários segmentos contemplados por estas políticas, pondo em prática uma ação de co-responsabilidade e mutualidade no trato com as demandas da comunidade acadêmica.

Com essa proposta, a PROPAAE organiza-se para identificar demandas junto aos estudantes e articular essas demandas aos princípios das ações afirmativas e da assistência estudantil. Esse exercício de construção coletiva permite identificar os focos de interesse dos estudantes e suas necessidades específicas. Nesse sentido, implantou-se um serviço de acompanhamento psicossocial e pedagógico, através dos Núcleos de Assistência Psicossocial (NUAPS), e de Apoio e Acompanhamento Pedagógico (NAAP), além de uma ação de fomento à vida comunitária, com ênfase no lazer, desportos, arte e cultura, materializada pelo Programa de Vivência Comunitária.

No que diz respeito às ações para o acesso ao ensino superior, a UFRB optou por adotar o mesmo sistema de reserva de vagas (cotas) para o ingresso na universidade, vigente na UFBA. Quando da criação da UFRB, $43 \%$ das vagas de todos os cursos eram reservadas a estudantes oriundos de escolas públicas e destes, $85 \%$ reservadas àqueles estudantes que se autodeclarassem negros (pretos e pardos). No ano de 2009, a UFRB aderiu ao Exame Nacional de Ensino Médio (ENEM) em $100 \%$ das vagas, eliminando, neste ano, o vestibular de seu processo 
seletivo. Outra ação inserida na política de acesso ao ensino superior é o Programa UNIVERSIDADE PARA TODOS. Este programa é uma parceria com o Governo do Estado da Bahia, através da Coordenação de Desenvolvimento do Ensino Superior (CODES), com universidades públicas do Estado e com a UFRB. Na UFRB, o Programa é gerenciado pelo Núcleo de Ações Afirmativas e Políticas de Acesso, vinculado à PROPAAE. Esta parceria possibilitou à UFRB criar e administrar cursos pré-vestibulares para alunos de $3^{\circ}$ ano e egressos, oriundos de escolas públicas, em oito municípios da Região do Recôncavo.

Para promover a permanência dos estudantes, instituiu-se o Programa de Permanência Qualificada, que visa garantir a permanência dos estudantes, nos cursos de graduação da universidade, através da concessão de diferentes modalidades de auxílios e bolsas, e que pretende assegurar a formação acadêmica de qualidade pelo engajamento dos estudantes em diferentes projetos de ensino, pesquisa e extensão. Os estudantes são convidados a participar dos processos seletivos dos programas e projetos vigentes, através de editais.

Segundo a página da PROPAAE na internet estas:

São ações que visam garantir a permanência 'assistida' de forma que promovam condições sócio-econômicas, pedagógicas, de saúde e psicológicas necessárias à formação cidadã-profissional no âmbito acadêmico, cultural, político e social do nosso público alvo (estudantes). Cumprindo com este objetivo, a PROPAAE disponibiliza diversos apoios: Acadêmico: auxílio a participação e/ou promoção em eventos, congressos (portaria 208/2007); isenção de taxas para diplomas e trancamentos. Auxílio Pecuniário vinculado à projetos (Auxílio ou bolsa MEC/Sesu hoje PROPAAE/ UFRB, Programa do Conexões de Saberes e da Fundação Clemente Mariani ${ }^{4}$ ). Auxílio Pecuniário vinculado à moradia. Acompanhamento pedagógico a bolsistas. Assistencial Social: abordagem grupal e individual. Encaminhamentos aos serviços de saúde e recursos da comunidade. Programa Vivência Comunitária. Auxílio ao material escolar e à

4 O Programa Conexões de Saberes e o Programa da Fundação Clemente Mariani foram extintos em 2009. 
saúde, Restaurante Universitário - RU; Moradia Estudantil. (PROPAAE, 2008)

\section{AS HABILIDADES SOCIAIS E O TREINAMENTO DE HABILIDADES SOCIAIS (THS)}

O campo das habilidades sociais, um domínio teórico-prático vinculado essencialmente à Terapia Cognitivo-Comportamental, é extremamente valioso do ponto de vista da promoção da qualidade de vida e bem-estar das populações. De acordo com Falcone (2001a, p. 202), "As habilidades sociais têm sido relacionadas à melhor qualidade de vida, a relações interpessoais mais gratificantes, à maior realização pessoal e ao sucesso profissional”. Neste campo, articulam-se conceitos, referenciais e técnicas, de diferentes abordagens com vistas a contribuir para relacionamentos sociais que representem vantagens do ponto de vista individual e social.

Caballo (1997, p. 230, grifo nosso) define habilidades sociais, de modo mais geral, como sendo um:

[...] conjunto de comportamentos emitidos por um indivíduo no contexto interpessoal, que expressa sentimentos, atitudes, desejos, opiniões ou direitos desse indivíduo de um modo adequado à situação respeitando esses comportamentos nos demais, e que geralmente resolvem uma situação ao mesmo tempo em que minimizam a probabilidade de problemas futuros $[\ldots]$.

Del Prette e Del Prette (2003b, p. 117) definem as habilidades sociais de modo ainda mais específico:

[...] o termo Habilidades Sociais aplica-se à noção de existência de diferentes classes de comportamentos sociais no repertório do indivíduo para lidar com as demandas das situações interpessoais. A competência social tem sentido avaliativo que remete aos efeitos do desempenho das habilidades sociais nas situações vividas pelo indivíduo [...] A competência social qualifica a proficiência desse desempenho e se refere à capacidade do indivíduo de organizar 
pensamentos, sentimentos e ações em função de seus objetivos e valores, articulando-os às demandas imediatas e mediatas do ambiente.

Do ponto de vista das habilidades sociais, há que se considerar o caráter situacional-cultural da competência social. Assim, admite-se que não existe o comportamento socialmente competente em si, ou seja, topograficamente preestabelecido como o mais adequado. As habilidades sociais e a competência social variam de indivíduo para indivíduo, e podem variar, num mesmo indivíduo, em função de fatores tais como idade, contexto social, papéis desempenhados em um dado contexto, dentre outros. A competência social, para ser atingida, exige que se considerem valores e normas socioculturais que, em certos momentos, podem estar em discordância com aqueles apresentados pelo indivíduo. (DEL PRETTE; DEL PRETTE, 2002)

Explicitando, mais detalhadamente, a definição de competência social, Del Prette e Del Prette (2002, p. 47) afirmam que:

[...] pode-se definir a competência social como a capacidade do indivíduo (auto-avaliada ou avaliada por outros) em apresentar um desempenho que garanta, simultaneamente: a) a consecução dos objetivos de uma situação interpessoal; b) a manutenção ou melhoria de sua relação com o interlocutor, incluindo-se aí a busca de poder e das trocas nessas relações; c) a manutenção ou melhoria da auto-estima; d) a manutenção ou ampliação dos direitos humanos socialmente reconhecidos.

Percebe-se que o conceito de competência social aponta para relações sociais mais equilibradas, onde se valoriza a autoestima do iniciador da ação, mas também se reconhece e atua de modo a respeitar a autoestima do outro, aquele que recebe a ação. Desse modo, constroem-se relações mais igualitárias, substituindo-se relações autoritárias. Ousaríamos dizer que, se a competência social fortalece a autoestima na dimensão individual, as ações afirmativas podem fortalecer a autoestima das identidades grupais, ou seja, por atuarem num nível coletivo 
permitem o reconhecimento e a afirmação de direitos, num domínio mais amplo, favorecendo também a autoestima das populações afetadas. Talvez estejamos falando de duas, ou mais faces, de um mesmo objeto.

Tem sido denominada de assertividade, conforme Lange e Jabukowski (1976 apud FALCONE, 2001b; DEL PRETTE; DEL PRETTE, 2002), a afirmação dos próprios direitos, assim como a expressão honesta e adequada de pensamentos, sentimentos e crenças respeitando os direitos dos outros. Esse conceito tem sido contraposto a duas ideias: a não-assertividade - passividade - e a agressividade. Os comportamentos assertivos, agressivos e passivos variam no grau em que contribuem para que o sujeito atinja seus próprios objetivos, mantenha a qualidade da relação, respeite o outro, e produza sentimentos e pensamentos afirmativos sobre si mesmo. O 'pensar assertivamente' é importante na compreensão da vida social que envolve, dentre outros aspectos, compreender os direitos humanos e universais; o direito de pensar que a vida pode ser melhor para si próprio e para outros; que, mesmo num sistema democrático, injustiças podem ocorrer e requerem a ação coletiva e individual para sua correção; que assertividade não é intolerância nem egoísmo; que agir assertivamente não implica em deixar de desculpar falhas alheias, por exemplo, e que o agir assertivamente pode não produzir os resultados externos esperados, mas nos fornece a sensação de satisfação interior produzida pelo fazer o que achávamos que devia ser feito. (DEL PRETTE; DEL PRETTE, 2003b) Para Del Prette e Del Prette (2003b, p.133), "Dentre as várias classes de habilidades sociais, as assertivas são as que mais se relacionam às crenças e noções sobre o mundo social, a justiça, o direito de acesso aos bens da cultura e às relações equilibradas." Os autores acrescentam, ainda, que o pensar e agir assertivamente transcende a busca por autoafirmação. Ao pensar e agir assertivamente, as pessoas procuram construir um mundo mais justo, mais igualitário, diríamos, especialmente quando acreditam na mobilidade social e, o que nos interessa, nesse momento, na inclusão social de grupos e pessoas historicamente marginalizadas. "Para essa 
pessoa, o comportamento interindividual não seria suficiente, e ela tenderia a engajar-se em ações de caráter intergrupal que poderiam ser denominadas de assertivas coletivas (movimentos sociais)." (DEL PRETTE; DEL PRETTE, 2003b, p. 133)

O THS pode ser entendido como um conjunto de técnicas de avaliação e intervenção em habilidades sociais. Um dos instrumentos de avaliação de habilidades sociais é o IHS-Del Prette, Inventário de Habilidades Sociais. (DEL PRETTE.; DEL PRETTE, 2001a) Del Prette A. e Del Prette Z. A. P (2002) afirmam "que este campo é formado por alguns modelos teóricos explicativos, como o modelo da assertividade; o modelo da percepção social; o modelo da aprendizagem social; o modelo cognitivo e o modelo da teoria dos papéis". ${ }^{5}$ Ainda segundo os autores:

[...] pode-se considerar que os princípios, os objetivos e os conceitos associados às técnicas de intervenção e de avaliação configuram-se como campo teórico-aplicado, com uma epistemologia própria. (DEL PRETTE; DEL PRETTE, 2002, p. 30)

O THS tem sido aplicado a diversas populações em diferentes áreas, tais como a clínica - transtornos afetivos e de ansiedade, esquizofrenia, problemas conjugais e familiares, abuso de substâncias psicoativas e escolas - indivíduos com retardo mental, deficientes sensoriais -, com vistas a aprimorar o desenvolvimento socioemocional e as habilidades interpessoais em escolares e com professores de diferentes segmentos escolares. (DEL PRETTE; DEL PRETTE, 2002) Cabe destacar que o THS demonstra-se eficaz, mesmo quando aplicado a populações não clínicas, como no caso de desenvolvimento de habilidades sociais em professores (DEL PRETTE A.; DEL PRETTE Z. A. P, 1997). Segundo Falcone (2001a, p. 202), “[...] o THS não se destina apenas ao tratamento de problemas clínicos, uma vez que os comportamentos sociais inadequados também são manifestados pela população não clínica”.

5 Estes modelos não serão explicitados neste artigo. Para mais detalhes, consultar Del Prette e Del Prette, 2002. 
Constata-se que o THS pode ser, também, adotado no desenvolvimento e promoção da qualidade de vida em diferentes fases da vida, como na terceira idade, com vistas à reorganização do estilo de vida, resolução de conflitos decorrentes de preconceitos, e na defesa e reivindicação de direitos. (DEL PRETTE A.; DEL PRETTE Z. A. P, 2002) Com base nessas compreensões e na análise de estudos da área de HS, afirmamos a possibilidade de uso do THS como estratégia complementar aos programas de ações afirmativas, visto que já tem sido usado com outras populações não clínicas. Esta possibilidade levanta novas questões: será necessário criar um inventário de habilidades sociais que envolva interações e desempenhos específicos das situações de discriminação racial? Quais as habilidades mais importantes a serem desenvolvidas que qualifiquem os sujeitos para o enfrentamento socialmente habilidoso, da discriminação racial? E, mais recentemente, pode, e/ou deve, o THS ser adotado como estratégia complementar de ações afirmativas no contexto da UFRB? Que vantagens isso representaria para os participantes?

Acreditamos que as questões levantadas devem agora passar a conduzir nosso olhar e que os argumentos citados acima são suficientes para mostrar que o THS pode servir aos propósitos de ação afirmativa complementar ao processo de inclusão social de pessoas negras (pretos e pardos). Estas, ao serem excluídas e/ou marginalizadas, ou sentiremse assim, são afetadas em sua identidade, autoestima e sentimento de pertença, sendo necessário desenvolver pensamentos, sentimentos e comportamentos, para lidar com as situações concretas produzidas pelos processos de exclusão.

A universidade pública é, portanto, um contexto onde a necessidade de se implantar o desenvolvimento das habilidades sociais justificase amplamente, uma vez que nela, atualmente, encontra-se um número crescente de indivíduos de origem popular, negros e egressos de escola pública que, mesmo de maneira dissimulada, podem sofrer discriminação. Além disso, sentem-se desconfortáveis, por terem ingressado através das políticas de ações afirmativas, ou correm o risco de evadir, 
vitimados também pela eventual opressão causada por atitudes preconceituosas dos diferentes segmentos institucionais, a saber: docentes, discentes e técnicos.

\section{CONSIDERAÇÕES FINAIS}

Para Munanga (2002), no prefácio do livro Psicologia social do racismo, a Psicologia brasileira teria muito a contribuir para a compreensão do racismo e suas consequências na vida das pessoas que discriminam ou que são discriminadas devido a características fenotípicas-raciais, i.e., relacionadas à aparência física. No domínio da Psicologia, são ainda recentes e escassas as pesquisas ligadas ao racismo e à discriminação racial, o que torna nossa tarefa ainda mais cuidadosa. Adicionalmente, sabemos que, em outras áreas, como as ciências sociais, história e educação, por exemplo, mais pesquisas têm sido produzidas, podendo influenciar algumas ações propostas, sejam por parte de governos, pesquisadores ou dos movimentos sociais. De acordo com Valente (1994, p. 9, grifo nosso),

Com o intuito de contribuir para a eliminação do racismo no Brasil, algumas ações vêm sendo desenvolvidas nos planos educativo, cultural e legal. Ações educativas e culturais são propostas por grupos negros organizados, por estudiosos e pessoas comprometidas com a luta anti-racista. No plano legal, a partir da promulgação do novo texto constitucional, em 1988, o racismo é um crime inafiançável e imprescritível. Coibir e punir as práticas racistas será o suficiente para acabar com elas?

Supomos que a resposta à pergunta enunciada pela autora vem sendo construída pelos movimentos sociais negros brasileiros, desde a escravidão. Ela aponta na direção das ações afirmativas como medidas alternativas e/ou complementares às medidas punitivas e proibitivas antidiscriminatórias.

Este texto é uma tentativa de ampliar a contribuição da Psicologia no que concerne ao problema da discriminação racial no Brasil. 
Esperamos ter apontado adequadamente que o THS é ferramenta que poderá auxiliar o indivíduo negro (preto ou pardo)/afrodescendente a construir sua identidade, suas cognições, crenças centrais e esquemas básicos, de modo mais afirmativo e positivo, tanto individual quanto coletivamente. Seus comportamentos e sua vida afetiva podem ser trabalhados, se ele assim o desejar, para que ele desenvolva um repertório cognitivo-comportamental de valorização de suas características étnico-raciais e para que adote atitudes individuais e coletivas de enfrentamento das desigualdades e injustiças a que pode estar submetido em diferentes situações.

Desse modo, é importante salientar o papel do THS, como uma estratégia de intervenção complementar e necessária, podendo auxiliar os Programas de Permanência voltados para Ações Afirmativas, no âmbito da PROPAAE /UFRB. O THS deve ser desenvolvido para auxiliar o processo de transformação social com vistas à redução das desigualdades sociais e à inclusão social dos estudantes universitários negros (pretos e pardos)/afrodescendentes, principais usuários destes programas.

\section{REFERÊNCIAS}

BENTO, M. A. S. Branqueamento e branquitude no Brasil. In: CARONE, I.; BENTO, M.A.S. (Orgs.) Psicologia Social do racismo: estudos sobre branquitude e branqueamento no Brasil. Petrópolis, RJ: Editora Vozes, 2002.

CABALLO, V. E. El papel de las habilidades sociales em el desarollo de las relaciones interpessonales. In: ZAMIGNANI, D. R. Sobre Comportamento e Cognição. Santo André, SP: ARBytes, 1997.

CARVALHO, José Jorge de. Bases para uma aliança branco-negro-indígena na luta contra a discriminação étnica e racial no Brasil. Cadernos CERIS, Rio de janeiro, n. 4, p. 13-34, 2004.

CAMPOS, A. C. B. Políticas de ação afirmativa? A implementação das cotas na Universidade estadual do norte fluminense nos vestibulares de 2003 e 2004. Dissertação (Mestrado em Política Social - UENF). Dissertação 
de Mestrado apresentada ao Programa de Pós-Graduação em Políticas Sociais da Universidade Estadual do Norte Fluminense-UENF. Campos dos Goytacazes, RJ. 2005

DEL PRETTE, A.; DEL PRETTE, Z. A. P. Habilidades Sociais e educação: Pesquisa e atuação em psicologia escolar / educacional. In: DEL PRETTE, Z. A. P. (org.). Psicologia Escolar e Educacional. Saúde e Qualidade de Vida. 2a. Edição. Campinas: Ed. Alínea, 2003.

. Inventário de Habilidades Sociais (IHS - DEL - PRETTE): manual de aplicação, apuração e interpretação. São Paulo: Casa do Psicólogo, 2001a. . Uma proposta de um sistema de classificação das habilidades sociais. In: GUILHARDI et al. (Org.). Sobre comportamento e cognição: expondo a variabilidade. Santo André, SP: ESETEC, $2001 \mathrm{~b}$.

. Psicologia das Habilidades Sociais. Terapia e Educação. 3. ed. Petrópolis, RJ: Vozes, 2002.

. Um programa de desenvolvimento de habilidades sociais na formação continuada do professor. In: Associação Nacional de pesquisa em Educação (ANPED), Minas Gerais, 1997. Anais... Minas Gerais, 29 p. CD-ROM

FERREIRA, R. F. O brasileiro, o racismo silencioso e a emancipação do afro-descendente. Psicologia e Sociedade, v. 14, n. 1, p. 69-86, 2002.

FERREIRA, R.; ANDRADE, A. Mapa das ações afirmativas no ensino superior. Programa Políticas da cor na educação brasileira. Laboratório de Políticas Públicas, Rio de Janeiro, n. 4, out. 2006.

LANE, S. T. O que é psicologia social. São Paulo: Brasiliense, 1995.

LANGE, J .L.; JAKUBOWSKI, P. Responsible Assertive Behavior. Illinois: Research Press, 1976.

FALCONE, E. M. Habilidades sociais: Para além da assertividade. In: WIELENSKA, R.C. (Org.). Sobre comportamento e cognição: questionando e ampliando a teoria e as intervenções clínicas e em outros contextos. $6 \mathrm{v}$. Santo André: ESETEC, 2001.

MINISTÉRIO DE EDUCAÇÃO - SeCRETARIA DE EEDUCAÇÃO CONTINUADA, ALFABETIZAÇÃO E DIVERSIDADE. O que é ação afirmativa? Rio de Janeiro: Coordenação do Programa Conexões de Saberes. 2007. 
MOURA, Clóvis. Sociologia do negro brasileiro. São Paulo: Editora Ática, 1998.

MUNANGA, B. In: CARONE, I.; BENTO, M.A.S. (Org.) Psicologia

Social do racismo. Estudos sobre branquitude e branqueamento no Brasil.

Petrópolis: Vozes, 2002. Prefácio

PRÓ-REITORIA DE POLÍTICAS AFIRMATIVAS E ASSUNTOS

ESTUDANTIS. Apoio ao estudante. Cruz das Almas, BA: UFRB, 2008. Disponível em: <http://www.ufrb.edu.br/propaae/index. php?option $=$ com_content $\&$ task $=$ view\&id $=92>$ Acesso em 05 de fev. de 2010.

SILVA, L. F. M. Estudo sociojuridico relativo à implementação de políticas de ação afirmativa e seus mecanismos para negros no Brasil: aspectos legislativo, doutrinário, jurisprudencial e comparado. Rio de Janeiro, 2004. Disponível em: <http://w3.ufsm.br/afirme/LEITURA/diantelei/dl02.pdf > Acesso em: 05 fev. 2010.

SISS, Ahyas. Afro-brasileiros, cotas e ação afirmativa: razões históricas. Niteróri/ PENESB, 2003.

VALENTE, A. L. E. F. Ser negro no Brasil hoje. São Paulo: Editora Moderna, 1994. 


\section{O BACHARELADO INTERDISCIPLINAR DA UNIVERSIDADE FEDERAL DA BAHIA o que dizem os estudantes? ${ }^{1}$}

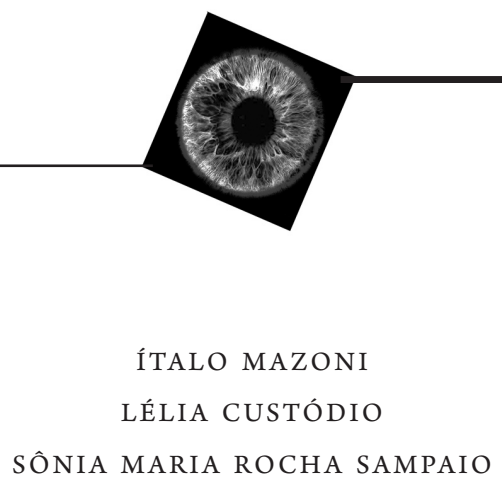

O projeto educativo previsto para os Bacharelados Interdisciplinares versa sobre uma formação acadêmica com plena interação entre as diversas áreas do conhecimento e, dess a forma, rompe com modelos pedagógicos tradicionais, de onde brota um saber compartimentado ou fragmentado que, aliás, já se mostrou e ainda se mostra insuficiente, pois não consegue dar conta da dinamicidade do mundo contemporâneo e dos temas transversais contidos neste. Tito $^{2}$, estudante do BI da Universidade Federal da Bahia

O Bacharelado Interdisciplinar (BI) é uma proposta de estruturação acadêmica para a educação superior, que sugere uma reestruturação radical, tanto do formato curricular, quanto dos conteúdos acadêmicos,

1 Este trabalho contou com a colaboração do bolsista Ilison Dias, do Programa Permanecer UFBA.

2 Todos os nomes dos estudantes são fictícios, para proteger sua identidade, como consta no Termo de Consentimento Livre e Esclarecido que assinaram, quando disponibilizaram os dados que foram utilizados para a elaboração deste artigo. 
com ênfase na interdisciplinaridade e integração de temas relevantes da cultura contemporânea em todas as suas quatro modalidades: $\mathrm{Hu}$ manidades, Artes, Ciência e Tecnologia e Saúde. Sua intenção é propiciar formação geral humanística, científica e artística, qualquer que seja o campo de saber escolhido pelo estudante. Ao invés de iniciar sua vida universitária a partir da escolha de uma formação específica, os estudantes vivenciam experiências interdisciplinares, podendo, ao final desse percurso, prosseguir seus estudos em cursos de progressão linear ${ }^{3}$, ingressar num programa de pós-graduação de seu interesse ou, simplesmente, interromper ali, sua formação. Além disso, ele pode entrar ou reorientar-se no mundo do trabalho, a depender das competências que tenha adquirido e, evidentemente, dos postos disponíveis.

$\mathrm{O}$ acesso a esses novos cursos dá-se através da nota obtida pelo aluno no Exame Nacional do Ensino Médio (ENEM). Durante o período de inscrição para o vestibular, o candidato deve escolher uma das quatro Grandes Áreas propostas: Artes, Humanidades, Ciência e Tecnologia e Saúde. Posteriormente, caso aprovado, poderá fazer opção por uma Área de Concentração, no início do quarto semestre letivo. A duração mínima do curso é de seis semestres, com conclusão prevista para, no máximo, oito períodos semestrais. O diploma atribuído, após a conclusão do Bacharelado Interdisciplinar, registrará a formação do estudante em uma das Grandes Áreas e, também, aquela realizada em uma das Áreas de Concentração, caso o aluno tenha integralizado seu currículo com esta última opção.

Para Almeida Filho (2007, p. 11), as novas modalidades de cursos abrangem as grandes áreas do conhecimento correspondentes às três culturas que estruturam os saberes e práticas do mundo contemporâneo. A Formação Geral dos BI contempla: a) Cultura Humanística; b) Cultura Artística; c) Cultura Científica. A cultura humanística busca novas e amplas definições sobre Humanidades, nos sentidos ecológico, político, de desejo e de cibermundo. A cultura artística contempla tantos as estéticas da

$320 \%$ das vagas dos cursos de progressão linear da UFBA estão reservadas para estudantes egressos dos Bacharelados Interdisciplinares. 
atualidade quanto as que já pertencem à tradição nesse campo. A cultura científica caracteriza-se pelo desenvolvimento científico e tecnológico, ética, epistemologia, metodologia, raciocínio quantitativo, entre outros. Nesse sentido, a educação superior seria reculturalizada e, consequentemente, a universidade reinventada. Ainda para esse autor, o BI também visa combater as alarmantes taxas de evasão da universidade brasileira, com a escolha mais consciente da formação profissional pelo estudante, dissuadindo uma profissionalização precoce e promovendo a diversificação acadêmica e laboral.

Em resumo, o BI teria, como metas e desafios, o aumento da oferta de vagas na educação superior, com maior inclusão social; o adiamento das escolhas profissionais, com o intuito de impedir prejuízos individuais e institucionais; a diminuição das taxas de evasão; um regime curricular flexível, que permite ao estudante compor parte significativa de sua formação, maior mobilidade intra e interinstitucional, interdisciplinaridade, integração entre os componentes curriculares, expansão na base dos estudos, com maior contato com as culturas da contemporaneidade, além de provocar reformas curriculares na formação profissional e acadêmica, visando maior eficiência da universidade pública.

Assim, é possível afirmar que o Bacharelado Interdisciplinar é uma nova forma de compreender e atuar na educação superior. As intervenções interdisciplinares sobrepõem-se às antigas práticas pedagógicas da academia, permitindo ao estudante uma formação ampla, diversa e mais ajustada à realidade complexa da vida contemporânea. Tudo isso exige um esforço institucional consistente e de longo prazo para se consolidar, na medida em que essas ideias e propostas são ainda contra-hegemônicas e sofrem resistência no interior mesmo da instituição universitária. Larrosa (2000, p. 07) nos ajuda a pensar sobre a necessidade de mudança:

[...] creio que para além ou para aquém de saberes disciplinados, de métodos disciplináveis, de recomendações úteis ou de respostas seguras; para além mesmo de idéias apropriadas ou apropriáveis, talvez seja a hora de tentar trabalhar no campo pedagógico pensando e escrevendo de uma 
forma que se pretende indisciplinada, insegura e imprópria. $\mathrm{O}$ discurso pedagógico dominante, dividido entre a arrogância dos cientistas e a boa consciência dos moralistas, está nos parecendo impronunciável. As palavras comuns começam a nos parecer sem qualquer sabor ou a nos soar irremediavelmente falsas e vazias. E, cada vez mais, temos a sensação de que temos de apreender de novo a pensar e escrever, ainda que para isso tenhamos de nos separar da segurança dos saberes, dos métodos e das linguagens que já possuímos (e que nos possuem).

Outras universidades públicas, além da UFBA igualmente repensam suas opções curriculares, a exemplo da Universidade Federal do ABC (UFABC) e da Universidade Federal de Juiz de Fora (UFJF). Apesar do modelo ser uma novidade no Brasil, em universidades norte americanas e europeias, essa transversalidade de saberes, guiada por uma forte preocupação com a formação geral dos estudantes, já está presente na educação superior, ressalvadas eventuais diferenças formais e operacionais, como entre os modelos americano e o modelo europeu de Bolonha, de 1998.

A preocupação central deste texto não se prende a justificar ou discutir, do ponto de vista teórico, a inovação pedagógica pretendida pelos Bacharelados Interdisciplinares, implantados na UFBA, em 2009. O que ele pretende é trazer à tona as preocupações, vivências, desejos e opiniões dos estudantes matriculados nesses novos cursos da UFBA, através de depoimentos escritos que eles nos forneceram, ao longo dos dois semestres do componente curricular Estudos da Contemporaneidade I e II, no primeiro ano de funcionamento do novo Instituto de Humanidades, Artes e Ciências, Prof. Milton Santos, que abriga os BI.

No momento em que se implantam inovações pedagógicas e curriculares em nossa universidade, pensamos que é de central importância compreender como o estudante optou pelo BI, quando não havia experiência social anterior em que se apoiar para tomar uma decisão tão importante quanto difícil: a escolha de um caminho a seguir na educação superior. Esta foi, precisamente, a primeira questão sobre a qual eles 
escreveram relatos. A segunda demanda colocada aos estudantes foi a de que eles comentassem, livremente, como transcorreu o semestre, não apenas tomando como base aquele componente curricular específico Estudos da Contemporaneidade - mas o conjunto dos componentes cursados, as relações com os professores e suas inquietações relativas ao curso. Os relatos foram lidos, agrupados tematicamente e, para informar este trabalho, selecionamos trechos de depoimentos que dão conta das dimensões mais importantes consideradas pelos estudantes.

\section{A ESCOLHA DO NOVO}

$\mathrm{O}$ ingresso no ensino superior brasileiro, desde seu estabelecimento em 1808, está reservado a uma pequena parcela da população, composta majoritariamente por camadas médias e pela elite econômica. (ROMANELLI, 2005) Depois de dois séculos decorridos de história, a massificação da educação superior ainda é uma realidade distante em nosso país.

Esta conjuntura, cristalizada ao longo da história brasileira, tem sido alvo de sucessivas tentativas de reconfiguração, principalmente a partir da segunda metade do século XX. A mais recente destas iniciativas é o Programa de Apoio a Planos de Reestruturação e Expansão das Universidades Federais (REUNI), criado pelo Decreto no 6.096, de 24 de abril de 2007, com o objetivo de criar condições para a ampliação do acesso e permanência na educação superior. Aderindo a este programa, no ano de 2009 é que a UFBA passa a oferecer os Bacharelados Interdisciplinares, como uma nova opção de formação universitária de graduação.

Ora, sendo o acesso à universidade pública, para o jovem brasileiro, uma meta difícil de ser alcançada, seja por conta do reduzido número de vagas existentes, seja em decorrência das disparidades econômicas e sociais que submetem muitos deles, a existência de uma nova modalidade de ingresso no ensino superior certamente trouxe dúvidas, mas, também, esperanças: 
O maior sonho na minha vida era entrar na Universidade Federal da Bahia por três motivos: primeiro porque não tinha condições de pagar uma faculdade privada, segundo porque para ser aluno [da] federal é privilégio para poucos, devido ao alto nível de ensino, concorrência, infraestrutura, e, terceiro, porque é uma faculdade valorizada no mercado. Porém, para realizar esse sonho, foi preciso eu caminhar muito, pois passei pelo processo seletivo quatro vezes e somente na quinta que conseguir chegar nessa vitória. Sou aluna [de] escola pública e tenho que estudar três vezes mais que um aluno que vem de uma boa escola, pois é muito difícil entrar em uma universidade onde você concorre [a] uma vaga com fortes concorrentes... Logo que terminei o primeiro semestre, agradeci a Deus por ter passado por essa etapa, que não foi fácil, afinal caloura, inexperiente, as dificuldades foram imensas. Mas, no final do processo, quando você faz a retrospectiva e vê que venceu essas dificuldades, é só alegria, explosão de sentimentos que não dá para explicar. ${ }^{4}$ (Tânia)

Parece clara também a opção pelo BI como forma de driblar as dificuldades impostas pela acirrada concorrência do vestibular, visto que, em seu primeiro processo seletivo, a prova fora diferenciada, eliminando a segunda fase para os candidatos a essa modalidade de curso. Já em 2010, o vestibular foi totalmente substituído pelo Exame Nacional do Ensino Médio (ENEM) para o ingresso:

[...] consegui abrir a página [da UFBA] que mostrava as propostas do BI. Achei interessante e resolvi que faria vestibular para Bacharelado Interdisciplinar em Saúde. Com as suas grandes vantagens, como, por exemplo, o horário do curso [noturno], a duração e diferenciação na prova, que seria de fase única e tinha a redação no lugar da língua estrangeira. (Mário)

Com a escolha do BI, ainda teve outros aspectos que se deram para a fundamentação desta escolha, tais como: maior facilidade na prova do vestibular, pois não me sentia tão preparado

4 Os depoimentos foram editados, apenas no sentido de trazer mínima correção gramatical aos trechos selecionados. 
assim, para enfrentar duas fases; pela Universidade estar dando a oportunidade, oferecendo um curso noturno, oferecendo a oportunidade para que pudesse trabalhar no turno oposto, enfim este curso me trouxe muitas expectativas. (Carlos)

Outro aspecto recorrente entre os relatos, no que concerne ao processo de escolha pelo BI, é o fato do curso oferecer um grande número de vagas no período noturno. No documento de diretrizes gerais do REUNI (MEC/SESu, 2007), na sessão "Diagnóstico da Educação Superior Brasileira”, onde são apontados alguns aspectos da estrutura de funcionamento do ensino superior, é enfatizado o fato de que "espaços físicos das unidades universitárias registram, não raramente, considerável ociosidade no período noturno". Isso é particularmente grave em relação à UFBA, que permaneceu, como única instituição de ensino superior federal do Estado da Bahia, por quase duzentos anos. A UFBA ofereceu seu primeiro curso noturno em 1999 (Licenciatura em Física), sendo que somente em 2007, outro (Licenciatura em Geografia) foi aberto, antes da adesão da instituição ao REUNI:

[...] Ano passado como de costume, abri a página da UFBA para ao menos sonhar, pensava que um dia conseguiria trabalho que [me] permitisse estudar, só que, para minha surpresa, lá estava o anúncio de cursos noturnos na UFBA, e de uma modalidade nova que me permitia estudar integralmente a noite $[. .$.$] . (Elias)$

É preciso considerar, quando se quer compreender os possíveis caminhos que levaram estudantes a optarem pelo BI, as dificuldades enfrentadas pelos jovens que concluem o ensino médio e devem escolher, com poucos ou nenhum elemento, uma profissão. Esta imposição, que é uma realidade do modelo educacional brasileiro, acarreta uma graduação voltada à profissionalização precoce e especializada:

Altos índices de evasão de alunos, descompasso entre a rigidez da formação profissional e as amplas e diversificadas competências demandadas pelo mundo do trabalho e, sobretudo, os novos desafios da sociedade do conhecimento. (MEC / SESu, 2007, p. 08) 
A esse respeito, vale lembrar um trecho do Parecer CNE/CES $\mathrm{n}^{\circ} .329$ de 11/11/2004, citado no Termo de Referência de adesão da UFBA ao REUNI:

O Brasil soube escolher o pior dos dois mundos possíveis. Dotado de ensino médio bastante frágil, optou pelo modelo de profissionalização precoce, que deixou indelével rastro na sociedade brasileira durante o século XX. Meninos e meninas, de 17 anos, às vezes menos, precisam decidir se serão médicos, advogados, professores, economistas, cientistas, filósofos ou poetas, opção que lhes assombrará todo o percurso de estudos universitários. $\mathrm{O}$ brasileiro que vai à universidade precisa ter certeza sobre seu futuro profissional, sua escolha de campo de saber ao qual dedicará maiores esforços, quando ainda nem finalizou adequadamente sua preparação para entender o mundo das distintas ciências, dos variados saberes. $O$ candidato à educação superior precisa saber que profissão terá, antes mesmo de claramente entender a complexidade do mundo do conhecimento. É candidato à profissão antes de ser candidato ao saber. (Parecer CNE/CES no. 329 apud UFBA, 2007)

Assim é compreensível que a escolha por um BI esteja carregada de uma sensação de "liberdade" e da evidente possibilidade de amenizar a angústia produzida por uma imposição do ponto de vista da destinação vocacional do futuro estudante universitário:

Uma coisa me chamou muita atenção, que é a liberdade dada ao estudante para mergulhar em vários campos do saber, e nesse contexto, poder escolher aquilo que mais lhe convém, o que mais lhe interessa. Foi então que resolvi prestar o vestibular para o BI em Humanidades. (Nilton)

[...] a proposta dos Bacharelados Interdisciplinares permite ao estudante conhecer e circular entre as diversas áreas do saber, a fim de torná-lo maduro o suficiente para a escolha que terá de tomar. Essa experiência de circular entre as variadas áreas objetiva preparar esse futuro profissional para o mercado de trabalho de um mundo contemporâneo, visa também transformá-lo em um profissional mais completo, mais culto e mais humano. (Luiz) 
A interdisciplinaridade, definida no projeto pedagógico dos Bacharelados Interdisciplinares (2008), como "o estabelecimento de nexos significativos entre os campos disciplinares” (p. 14) foi considerada importante pelos estudantes, ao confirmarem sua escolha pelo BI. A possibilidade da integração de conhecimentos e a proposta de modelos pedagógicos mais condizentes com a realidade contemporânea mostraram-se decisivas na preferência pelo BI pelos estudantes:

Era poder ter a oportunidade de estudar disciplinas em um só curso; era unir a minha paixão por biologia com arte; era formar de modo interdisciplinar, ganhar experiências para poder julgar o interessante ou não nos outros cursos; era poder escolher uma profissão, não somente estudando suas especialidades, mas aprender a enxergar seus outros horizontes, poder resolver um problema sobre formas diferentes, não ser uma parte e sim um todo. (Alice)

Percebi que através da interdisciplinaridade, onde a arte, as ciências, as humanidades estão juntas, o ser humano encontra oportunidade de desenvolvimento de suas potencialidades. Reconheço que o Bacharelado Interdisciplinar vem contribuindo decisivamente para o meu crescimento humanístico e intelectual. O nível elevado de criticidade e compromisso de alguns professores inspiraram-me a seguir buscando o aperfeiçoamento da minha pesquisa e prática enquanto aprendiz e aprendente. (Leandro)

\section{AS NOVAS VIVÊNCIAS}

Após vencerem o desafio da escolha pelo BI, o processo seletivo e a fase de apresentação de documentos, os primeiros alunos ingressantes tinham outra tarefa: a de colaborar para a consolidação do novo curso. Tarefa nada fácil, considerando todo o processo antecedente à sua criação, cheio de momentos conturbados, como nos diz, o então Reitor da UFBA, em publicação com o sociólogo português Boaventura de Sousa Santos, sobre a inovação na universidade:

O REUNI sofreu intensa oposição de parte do movimento estudantil. Em 25 universidades federais, houve tumulto 
e violência em reuniões de Conselhos Universitários; 14 Reitorias foram invadidas; 9 dessas ocupações somente terminaram mediante emissão de mandados judiciais de reintegração de posse. Em nossa Universidade Federal da Bahia, manifestantes tentaram, sem sucesso, impedir reuniões do Conselho Universitário, agendadas para deliberar sobre a implantação do Programa em nossa universidade. Inconformados com a decisão majoritária do Conselho e das Congregações de 26 das 30 unidades de ensino que compõem a UFBA, ocuparam a Reitoria. Apesar da reação, no prazo, todas as 54 universidades federais brasileiras aderiram ao Programa REUNI. (SANTOS; ALMEIDA-FILHO, 2008. p. 189)

Evidentemente esta é uma versão dos fatos e, até por interesse histórico, é preciso compreender os protestos ocorridos em 25 universidades brasileiras contra a nova proposta; contudo, neste trabalho, não cabe esta análise, sendo esta lembrança apenas um registro do clima no qual os estudantes do BI ingressaram na UFBA, possibilitando melhor aproximação dos sentidos expressos por eles sobre o momento inicial do curso.

Bacharelados Interdisciplinares. Quem um dia poderia imaginar algo deste tipo? É verdade, poucos imaginavam e até mesmo eu custei a acreditar. Mesmo com toda a insegurança que inicialmente rondava a minha cabeça, cá estou eu, fazendo um dos BI. (Maria Catarina)

Apesar das dificuldades de implementação do BI, de estarmos no cerne das polêmicas de toda a instituição e de conviver dia a dia com a incerteza quanto às áreas de concentração, sobre a continuidade do curso nesse ou noutro local e a falta de orientação profissional sobre o que faremos depois da conclusão do curso, sinto-me feliz em ter a oportunidade de ter acesso ao conhecimento que nos foi negado, durante décadas, $[\mathrm{n}]$ esse país que sempre privilegiou as classes mais abastadas. (Jorge)

Quando passei no vestibular foi muito complicado, porque todos ficavam perguntando que curso eu tinha passado e quando eu respondia, diziam: O que é um BI? Você não queria Medicina? Para que serve isso? Confesso que demorei um 
pouco para me acostumar com isso, e desenvolvi um sentimento de frustração. (Antônio)

O pioneirismo dos estudantes do BI está marcado pelos conflitos inerentes à mudança, ao fato de frequentarem não apenas um curso novo, mas uma nova e desconhecida modalidade de ensino superior, ainda ignorada na sociedade brasileira. Assim aparecem em seus relatos críticas e preconceitos sofridos relativos à sua escolha pelo BI.

Socialmente ainda somos muito rejeitados, muitos não valorizam o nosso curso e acredito que isso foi pivô para que muitos colegas desistissem. Porém, eu tenho certeza que fiz uma boa escolha, e o que, no começo, pensava que seria apenas uma ponte, hoje tenho consciência que é um curso que me fará uma profissional mais humana e preocupada com o social, [melhor] do que muitos formados pelo sistema linear. (Mariana)

[...] fora da universidade existe um forte preconceito contra o curso, por muitas vezes fui interrogada em outras instituições, com perguntas do tipo: "Quando vocês se formarem onde vão trabalhar?" "Qual o caminho [a] seguir depois de decorrido os três anos do curso?” Foram tantas outras piadinhas sobre o projeto do bacharelado... Parece que as pessoas se incomodam com o curso, não entendem seu projeto, sua finalidade. (Mariana)

Como lembram Santos e Almeida-Filho (2008, p. 40), quando discutem a crise da universidade pública

O conhecimento universitário - ou seja, o conhecimento científico produzido nas universidades ou instituições separadas das universidades, mas detentoras do mesmo ethos universitário - foi, ao longo do século XX, um conhecimento predominantemente disciplinar $[. .$.$] .$

Assim, quando uma proposta como a do BI é apresentada a um contexto acadêmico historicamente rígido, hierárquico, e com pouca familiaridade com os conceitos de interdisciplinaridade, as contradições e conflitos de adaptação tornam-se inevitáveis: 
[... o IHAC ainda está meio ilhado em relação ao restante da universidade... estamos imersos em um curso novo, e por isso todos os docentes e discentes estão tentando se adequar às propostas vigentes, e claro que por isso, estamos constantemente nos deparando com dificuldades, principalmente porque os demais cursos da UFBA ainda não estão familiarizados conosco. (Manoel)

[...] Sei que muitos dentro da UFBA olham para os BI com maus olhos. Tanto docentes quanto discentes, por não conhecerem a proposta do BI, torcem o nariz para nós. (Maria Carolina)

Estas contradições foram inclusive observadas em relação ao processo pedagógico aplicado ao $\mathrm{BI}$, que privilegia "práticas pedagógicas inovadoras e mais compatíveis com as características cognitivas de indivíduos de uma Sociedade do Conhecimento de base tecnológica”. (UFBA, 2008, p. 30)

No segundo semestre o curso está sendo oferecido de forma prazerosa, e às vezes não. Muitos professores são competentes e capazes de brilhar no seu ensino, tentam conduzir uma pedagogia renovadora, transformadora, outros não sabem por que estão assumindo a sala de aula de um curso novo. (Sandra)

Torna-se preocupante e incoerente a relação "Universidade Nova”:

Pedagogias velhas é claro que não podemos atribuir [isso] a todos os professores do quadro do BI. Sempre gosto de ficar no papel de observadora, principalmente das posturas pedagógicas de professores que estão inseridos na proposta inovadora metodológica do BI e continuam com a tradição do ensino bancário, tenho observado posturas ainda autoritárias em que o aluno deve ficar no papel passivo no processo ensino aprendizagem... Sabemos que tudo é um processo e quem sabe no papel de beija-flor, em que cada professor possa fazer a sua parte ajudando [a] apagar o incêndio na floresta (transformar a educação institucional) quem sabe um dia conseguiremos estabelecer uma educação de nossos sonhos. (Rosana) 
[...] havia alguns professores que não haviam se enquadrado no perfil dos BI e traziam arraigados em suas aulas a mesma forma de ensino arcaica e linear da UFBA tradicional e outros que eram verdadeiros mestres no ofício do ensino. (José)

É uma nova e inteira realidade que requer um novo olhar do mestre, um novo fazer pedagógico, uma nova postura diante da realidade: livre dos preconceitos, das opiniões pré-fabricadas. $\mathrm{O}$ aluno, mais que antes, deixa de ser tábula rasa, ele traz saberes, traz percepções, traz vontades, enfim o aluno do BI deve representar a oportunidade de reciclarmos, todos, professores e discentes, as nossas posturas a nossa relação com o conhecimento. Num mundo em que o conhecimento se adquire por vias múltiplas e com a espantosa velocidade nos leva a entender que é preciso perceber a descentralização do papel do mestre. (Igor)

Os Bacharelados Interdisciplinares atraíram um conjunto extremamente diversificado de estudantes. Estão presentes jovens, adultos, pessoas maduras, os que visam o ingresso nos cursos tradicionais ou ainda pessoas em busca de ampliar seus conhecimentos, sem intenção de se profissionalizar ou reorientar suas carreiras:

O BI demonstra uma nova realidade que, talvez a Nova Universidade ainda não tenha aprendido como lidar. Ao contrário de outros tempos, o perfil do alunado é mais complexo em todas as dimensões; a faixa etária é menos homogênea, devendo-se dar oportunidades a jovens e menos jovens; as formações são as mais diversas, o que exige um maior cuidado na informação, as origens sociais e econômicas, de igual forma, variadas, enfim, qualquer que seja o recorte que façamos, encontraremos as diferenças. E quando se trata de diferenças desta ordem é preciso que também sejam adotadas, em sala de aula, práticas diferentes daquelas consolidadas como efetivas e funcionais. (Josiane)

Quanto às pessoas que encontrei por aqui, isso foi o que mais me impressionou. Nunca me imaginei encontrar com pessoas tão diferentes, em todos os sentidos, num curso como esse. Eu imaginava ver tantos [muitos] jovens, mas 
acabei encontrando gente de todas as idades. Tenho colegas já formados em outro curso, às vezes até mais de um curso. Tem até professor de pós-graduação fazendo BI. Tem pais e mães de família, avós, ricos, pobres, estudantes recém-formados do colegial, advogados, secretárias, dentistas, professores, enfermeiros. Todos muito corajosos de entrar de cabeça nesse novo projeto que a UFBA pretende, no futuro, aplicar para todos os novos estudantes. (Marília)

No texto do projeto pedagógico dos Bacharelados Interdisciplinares (UFBA, 2008), a educação superior é apontada como "vanguarda da produção, disseminação e inovação do conhecimento elaborado, em todas as suas manifestações", contudo o mesmo texto nos lembra que estas instituições

continuam praticando modelos de formação humana e profissional concebidos para modelos de sociedade que dão sinais de exaustão, ou simplesmente desapareceram. Tornamse, desse modo, incompatíveis com as novas configurações da chamada Sociedade do Conhecimento e, por conseqüência, Sociedade da Educação. (UFBA, 2008, p. 11)

Assim a busca por inovações no processo de ensino e aprendizagem aparece como uma busca constante no cotidiano dos alunos do BI, fazendo com que estes exercitem um extenso e profundo olhar crítico sobre o mundo que os cerca. Neste contexto, os professores parecem também aprender com os alunos, desconstruindo o lugar de detentores exclusivos do saber.

Com isso, o componente curricular Estudos Sobre a Contemporaneidade II traz experiências variadas e importantes, não só no sentido de conteúdos, mas referente a dar ênfase ao transdisciplinar e multidisciplinar; um outro ponto é o destaque dado [ao] aluno, para que ele possa falar o que pensa diante de determinado assunto, traga suas impressões e opiniões, e isto mostra uma postura adequada da professora e uma reformulação que se pretende na universidade nova; e isto é seguido por todos os docentes que tenho nes- 
te semestre. É fundamental que cada estudante esteja consciente e engajado na proposta de um novo ensino, e ciente da relevância de fazer "links" e ser autônomo no processo de aprendizagem. Quer vivência mais gratificante que esta que foi citada? (Jader)

Só consigo expor o melhor de mim quando tenho liberdade de expressão e tempo livre para pensar [...] A aula dela é mais light e sua metodologia de ensino é diferenciada. Ela busca afastar-se um pouco do modelo tradicionalista, em que o professor retém todo o conhecimento e ocupa posição central frente a seus alunos, que tudo têm a aprender. A primeira alteração notória é a disposição com que arruma a sala de aula. É feito um semicírculo, dispondo os alunos uns de frente para os outros, a fim de que todos se vejam, incluindo a professora. Esta nos orientou que esse "cenário" nos remete à ideia de que, apesar do professor representar uma autoridade em seu ambiente de trabalho, ele é aprendiz como todos ali são e estes podem transmitir seus distintos saberes, a fim de acrescentar à realidade do outro. (Kátia)

Todo este contexto de mudança e inovação revela-se líquido, cheio de indefinições. A julgar pelo que dizem os estudantes, a implantação de uma nova arquitetura acadêmica, no seio de uma instituição sexagenária como a UFBA tem se mostrado um desafio para a administração central e uma fonte de incerteza e insegurança para os novos alunos. Questões vitais sobre o funcionamento do BI, tais como aquelas a respeito de como se daria o ingresso dos alunos do BI nos cursos tradicionais, caso optassem por essa via, ainda eram, à época da elaboração dessas narrativas, motivo de grande inquietação.

Existe ainda uma grande brecha nos Bacharelados Interdisciplinares, muitos pontos precisam ser fechados. Por exemplo, a forma como se dará o ingresso nos cursos de extensão [progressão linear] ainda é uma grande incógnita. Muitas dúvidas ainda nos cercam. Mas acredito que até o final desse semestre conseguiremos fechar tudo que está em aberto. Até porque novos alunos entrarão em 2010.1 e serão ainda mais pessoas buscando e cobrando respostas. (Luiz Alberto) 
Espero que no semestre que vem muitas coisas tenham melhorado e que os coordenadores do $\mathrm{BI}$ já tenham respostas para todas as nossas dúvidas, como: Qual será a forma de entrada nos cursos de progressão linear, vai ser por escore ou por prova? Ou até mesmo responder se realmente irá ter cotas na passagem do BI para os cursos lineares. Essas e outras questões precisam ser resolvidas o mais rápido possível, pois vai ser a partir delas que eu vou decidir se continuarei ou não no BI. (Paulo)

Estas indefinições aliadas a toda conjuntura interna e externa relacionada aos BI, já descrita ao longo deste artigo, produziram em estudantes uma sensação de desamparo e receio em relação ao futuro, alimentando inclusive os índices de evasão:

Quando o BI será um curso que realmente os alunos possam vivê-lo de uma forma mais "tranquila" sem ficar o tempo todo se interrogando: ' $\mathrm{E}$ aí como vai ser a grade do próximo semestre?' 'Já decidiram os critérios de seleção para as áreas de concentração?' 'E quanto aos cursos profissionalizantes, como será a nossa entrada?' Talvez, quando esse momento chegar, os colegas comecem a pensar menos em abandono, e a enfrentar o terrível preconceito que sofrem por serem alunos do BI, 'os ratinhos de laboratório', assim nos chamam por aí, teremos mais certezas e mais maturidade para explicar e argumentar sobre nosso curso e, consequentemente, estaremos mais preparados para lidar com esse preconceito. (Antônio)

Aproximadamente [há] umas três semanas ou mais, vários discentes se questionavam sobre o $\mathrm{BI}$, sua formação enquanto profissional, o medo de perderem seu tempo em algo que não tinha muita coisa definida e as respostas cobradas por familiares, amigos e parentes. Vi pessoas chorarem. (Tomás)

Um fato que me chamou a atenção nesse segundo semestre foi o índice de desistências nas turmas de saúde, o que é reflexo da incerteza e da insegurança de um futuro que ainda nos parece tão incerto. (Antônio) 


\section{PARA FINALIZAR}

A ideia de uma contradição ou mesmo antagonismo entre formação ou educação geral e formação especializada, profissional, só pode ser compreendida pelo estudo do desenvolvimento da instituição universitária ao longo de sua história, iniciada no Renascimento do século XII. O binômio ensino-pesquisa da universidade humboldtiana e o caráter cartesiano e instrumental da universidade napoleônica francesa subordinam as funções da universidade relativas ao conhecimento, no sentido largo, à função de formação profissional focada em um campo especializado do saber.

Assim, um estilo pragmático e imediatista assume, especialmente a partir do século XIX, a dianteira do foco dessa instituição, impulsionado por mudanças sociais que exigem profissionais preparados e capazes de acionar tecnologias que respondam às exigências de "progresso" e "desenvolvimento" num mundo que se industrializa de forma veloz. Esse movimento, que atende a uma compreensão de homem que engendra o sujeito moderno, capaz de impessoalidade e neutralidade, deverá afastar da universidade seu caráter especulativo e metafísico anterior, dando lugar a um discurso que se apoia no conhecimento objetivo e racional. Tudo o que não se enquadra nessa lógica matematicizada é excluído do saber científico e, portanto, não mais faz parte da formação dos indivíduos que buscam universidades como espaço formativo.

Convivemos com um estilo de educação superior que ainda prioriza a especialização via formação profissional deixando à própria sorte os jovens que têm por missão formar no sentido mais amplo:

[...] as universidades, com sua cultura profissionalizante histórica, continuam imaginando ou fingindo que a formação cultural de seus ingressantes, adquirida no ensino médio, teria sido satisfatória [...] A maioria deles não teve educação geral adequada no ensino médio e provavelmente não a terá na universidade, o que não os impedirá de [...] sair dela 'treinados' como bárbaros especializados, ansiosos para ingressas no mercado de trabalho. (SANTOS FILHO, 2007, p. 19) 
É no período da vida universitária que os estudantes têm uma das melhores possibilidades de confronto com a riqueza do conhecimento humano materializado pelo tripé ciência, cultura e arte. Ainda que prossigam sua formação e optem por uma das vertentes do saber especializado, se forem expostos à diversidade do que foi produzido por diferentes sociedades, ao longo de nossa história, o foco profissional adotado será enriquecido dando mais oportunidade a uma movimentação social alicerçada em valores coletivos, em proveito do homem. A realidade do segundo ano de funcionamento dos Bacharelados Interdisciplinares do Instituto de Humanidades, Artes e Ciências Prof. Milton Santos da UFBA, em que pesem todas as dificuldades, confirma o acerto de sua proposição e implantação. A fala dos estudantes pontua esse acerto, ainda que a insegurança a respeito do futuro apareça em suas falas. Essa insegurança, é bom lembrar, deve-se não apenas ao fato do BI ser uma proposta ainda debutante. O olhar suspeito, de dentro e de fora da universidade, que cobra uma coerência desse projeto a uma lógica que lhe é estranha - a profissionalizante - corrobora para esse sentimento que, entretanto, conta com uma cultura, nascente, não hegemônica, mas partilhada por muitos dos seus idealizadores, professores, gestores e estudantes, para conseguir se firmar.

No cenário de nossa universidade, ainda são inúmeros os entraves, preconceitos, rotinas estabelecidas historicamente que se contrapõem à adoção de uma nova lógica de formação dos estudantes. Os procedimentos burocráticos e administrativos precisam ser ajustados e alguns totalmente modificados, como os relativos ao cardápio de componentes curriculares ofertado a cada semestre. Se a oferta é pouco diversificada, ela não permite que o estudante desenvolva itinerários próprios, forçando-o a adotar percursos pouco flexíveis, o que contradiz a proposta original dos BI. Mas isso depende do engajamento das unidades, quase todas disciplinares, para que a formação geral, materializada pelos BI, faça parte do seu cotidiano. Dessas unidades também depende a definição de novas áreas de concentração que ampliem links com o 
conhecimento mais especializado e o acolhimento aos estudantes que decidirem seguir um curso de progressão linear.

Uma pedagogia universitária que privilegie a inovação deve ser desenvolvida e se impor como horizonte que favoreça a experimentação e a adaptação de procedimentos às novas tecnologias disponíveis. A ideia do privilégio à formação docente in situ, em oposição à lógica in vitro, substitui a compreensão de professores sendo formados por outros que desconhecem as características de seus espaços de aprendizagem. A experiência em curso, de planejamento e avaliação cooperativa dos cursos, é crucial para o desenvolvimento da proposta. Os depoimentos dos estudantes pontuam, com insistência, a importância do mundo da sala de aula na concretização da proposta dos BI na UFBA. Essa questão é central para a consolidação do primeiro ciclo universitário em nossa instituição. Todo o esforço teórico e administrativo para materializar essas ideias se liquidifica se a relação do professor com seus alunos não se modificar em direção à inovação e a abordagens dialógicas.

Ouvir os estudantes e publicar suas dúvidas, inseguranças e/ou entusiasmo nos parece crítico na confirmação da educação geral, que privilegias as três culturas, avance e contamine a universidade com novas ideias pedagógicas.

\section{REFERÊNCIAS}

LARROSA, Jorge. Pedagogia Profana. Danças, piruetas e mascaradas. Belo Horizonte: Autêntica, 2000.

ALMEIDA-FILHO, Naomar de. As Três Culturas Na Universidade Nova. Ponto de Acesso, Salvador, v. 1, n. 1, p. 5 -15, jun. 2007. Disponível em: <http://www.portalseer.ufba.br/index.php/revistaici/article/view/1390> Acesso em: 08 maio 2010.

SANTOS, B. S.; ALMEIDA-FILHO, N. A Universidade no Século XXI: para uma Universidade Nova. Coimbra, 2008. Disponível em: <http:// www.boaventuradesousasantos.pt/media/A\%20Universidade $\% 20$ no\%20 Seculo\%20XXI.pdf>. Acesso em: 08 maio 2010. 
ROMANELLI, Otaíza. História da Educação no Brasil. 29.

ed. Petrópolis: Vozes, 2005

MINISTÉRIO DA EDUCAÇÃO / SECRETARIA DA EDUCAÇÃO

SUPERIOR. Diretrizes Gerais do REUNI. Brasília, 2007. Disponível em:

$<$ http://portal.mec.gov.br/sesu/arquivos/pdf/diretrizesreuni.pdf >. Acesso em: 08 maio 2010.

UNIVERSIDADE FEDERAL DA BAHIA. Termo de Referência de adesão da UFBA ao REUNI. Salvador, 2007. Disponível em: <www.ici.ufba.br/twiki/ pub/.../UFBA_REUNI_TERMO_REFERENCIA.doc $>$. Acesso em: 08 de maio de 2010.

UNIVERSIDADE FEDERAL DA BAHIA. Bacharelados Interdisciplinares: projeto pedagógico. Salvador, 2008. Disponível em: <http://www.portal. ufba.br/destaques/implant_reuni.pdf> Acesso em: 08 de maio de 2010 .

SANTOS FILHO, José Camilo. Educação geral na universidade como instrumento de preservação da herança cultural, religação de saberes e diálogos de culturas. In: PEREIRA, Elisabete Monteiro de Aguiar. Universidade e Educação Geral. Para Além da Especialização. Campinas: Alínea Editora, 2007. p. 17-64. 


\section{A EVASÃO NA EDUCAÇÃO SUPERIOR entre debate social e objeto de pesquisa}

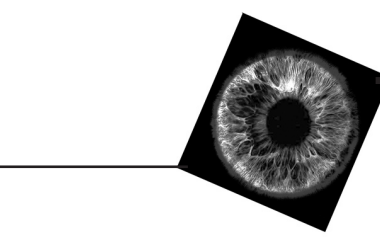

GEORGINA GONÇALVES DOS SANTOS

LÉLIA CUSTÓdIO DA SILVA

\section{INTRODUÇÃO}

A julgar pelo volume e datação da literatura, é recente a preocupação da pesquisa brasileira com a evasão em cursos da educação superior ${ }^{1}$, tema que interroga, ao mesmo tempo, a sociedade e a instituição universitária. Evasão foi, e ainda é, tema privilegiado da pesquisa em escolas de ensino fundamental e de ensino médio e a fragilidade de estudos nessa área, com foco na educação superior, é o que permite um relativo ofuscamento das suas causas e extensão, quer em universidades públicas ou privadas.

De qualquer forma, num país que ainda lida com a necessidade de universalizar o ensino médio, parece paradoxal que o aluno ultrapasse todas as barreiras impostas ao acesso à educação superior pública,

1 O Sistema Nacional de Avaliação da Educação Superior foi criado apenas em 2004. 
e dela desista, ao final de um tempo variável, em que o primeiro ano é crucial. O nosso objetivo, com a elaboração deste texto, além de ensaiar uma discussão conceitual, em virtude da relativa imprecisão identificada na literatura sobre o termo evasão, é polemizar e interrogar o fenômeno em relação a jovens universitários. Preferimos esse caminho mais que oferecer explicações, soluções e saídas.

Interessam-nos muito as perguntas novas que podem ser colocadas, pois este é um objeto privilegiado da pesquisa sobre a universidade contemporânea, pela simples constatação de sua amplitude, em instituições aqui e além de nossas fronteiras. Infelizmente, o fenômeno não atinge apenas países como o nosso, que ainda exibe fortes índices de jovens sem acesso à educação superior. Países da comunidade europeia, a exemplo da França, cuja realidade nos é familiar e que detém longa tradição de massificação da educação em todos os níveis, debatem-se, igualmente, com a saída de estudantes universitários não diplomados. $\mathrm{Na}$ opinião de Coulon (2008, p. 31), “Hoje o problema não é entrar na universidade, mas continuar nela $[. .$.$] ”, referindo-se à gravidade da$ situação que atinge o sistema universitário francês.

Existem, no Brasil, 183 universidades, 97 públicas e 86 privadas. Funcionam ainda 124 centros universitários, em sua grande maioria privados, e 1.911 Faculdades igualmente quase todas privadas ${ }^{2}$ Um total de 910.537 estudantes ingressou em universidades, em 2008: 67\% em universidades privadas e $33 \%$ no sistema público.

Um dos indicadores utilizados para realizar a avaliação de uma instituição de educação superior é a sua taxa de evasão. Quanto menor ela é, mais diplomados são disponibilizados à sociedade. Se os índices de evasão são consideráveis, podemos concluir que existem problemas e disfuncionamento, sem, contudo, podermos afirmar, no caso deles serem baixos, que tudo ocorre de forma satisfatória ${ }^{3}$.

2 Dados do Instituto Nacional de Estudos e Pesquisas Educacionais Anísio Teixeira (INEP) de 2008.

3 A taxa de evasão é calculada como o complemento em relação a 1 , da razão entre o número de concluintes no ano n e o número de ingressantes no ano n-3. Multiplicando- 
A tabela a seguir apresenta a evolução das taxas de evasão para o setor público e o privado, de 2002 até 2008, último ano disponível na sinopse do INEP:

\begin{tabular}{lccccccc}
\hline Taxa Evasão & 2002 & 2003 & 2004 & 2005 & 2006 & 2007 & 2008 \\
Universidade Pública & $25 \%$ & $27 \%$ & $23 \%$ & $37 \%$ & $41 \%$ & $45 \%$ & $42 \%$ \\
Universidade Privada & $42 \%$ & $46 \%$ & $56 \%$ & $52 \%$ & $55 \%$ & $54 \%$ & $52 \%$ \\
\hline
\end{tabular}

Fonte: INEP

De forma geral, segundo esses dados, as universidades públicas encontram-se em melhor situação que as de caráter privado, no período observado. Entretanto, mesmo nessas instituições, o problema pode ser considerado grave e apresenta uma tendência a evoluir, mesmo que, em 2008, seja observada uma ligeira queda de $3 \%$ em relação ao ano anterior. Sublinhamos que este texto tratará exclusivamente da saída de jovens do sistema público de educação superior, não apenas porque é nesse sistema que estamos engajados, mas por que pensamos que os condicionantes do eventual abandono dos estudos, no sistema privado, passem talvez por caminhos diferentes.

Uma das vertentes de compreensão da evasão em universidades analisa o tema enfatizando a falência do preparo anterior dos estudantes para as exigências da vida acadêmica. Esta pode ser apenas uma via fácil diante da complexidade que temos diante de nós. Com isso, não excluímos do problema, a participação das escolas de nível médio, sejam elas públicas ou particulares.

O fato das escolas médias privadas terem como foco, quase exclusivo, auxiliar os jovens a ultrapassar a barreira do vestibular, em cursos de progressão linear, resulta num preparo muito insuficiente em habilidades importantes, que auxiliem o futuro estudante universitário nessa nova etapa; o exemplo prático para nossa constatação é que, mesmo treinados para passar a barreira do ingresso na universidade, os estu- 
dantes enfrentam muitas dificuldades na produção de textos acadêmicos. Em escolas públicas, ao menos na realidade que conhecemos, nordestina, baiana, além da oferta de uma educação qualitativamente deficitária, não se realizam esforços significativos para promover a continuidade dos estudos ${ }^{4}$, facilitada, no caso de nossas universidades, pelas políticas de ações afirmativas por elas adotadas. Detemo-nos agora na nomenclatura utilizada e nas diferentes motivações apontadas para o abandono de um curso superior por alguns estudos nesse campo.

\section{DA NOMEAÇÃO DO FENÔMENO E DE SUAS MOTIVAÇÕES}

Realizados há bastante tempo para tratar do desengajamento de crianças e jovens da escola fundamental ou média, os estudos sobre evasão chegam tardiamente à educação superior ${ }^{5}$. As palavras utilizadas comumente nesses trabalhos foram, dessa forma, retomadas para designar experiências pretendidas como similares. Aqui, um primeiro cuidado é necessário: é possível que o fenômeno não seja o mesmo, ou não esteja submetido às mesmas injunções, quer se trate de uma criança de 9 anos, de um adolescente de 14 ou de um jovem de 22 anos, ainda que igualmente nomeado em todos os casos. A palavra evasão, utilizada na área das ciências da educação para designar a saída de indivíduos matriculados em qualquer nível do sistema educacional requer, assim, alguma precaução e exame prévio.

Originalmente, a palavra é sinônimo de fuga, evitação e desvio. Seu contrário quer dizer continuar, ficar, estar cativo, aprisionado, prisioneiro. Coulon (2008) irá referir dois fenômenos diferentes: eliminação,

4 Dados de pesquisa realizada pelo Observatório da Vida Estudantil, em 2008, em escolas da rede pública de Salvador.

5 Segundo Moelhlecke (2007), a primeira vez que se realizou um estudo de âmbito nacional para o acompanhamento de estudantes universitários, foi em 1997, quando foram analisadas, não apenas as taxas de evasão, mas também de diplomação e de retenção de cursos superiores públicos no Brasil. O estudo, entretanto, não contemplou causas e/ ou motivações para a evasão, nem os fatores que influenciam as taxas de diplomação e retenção. 
quando os estudantes, em função de fracasso repetido ou não, interrompem o curso que fazem e abandono (autoeliminação), que ocorre por iniciativa do estudante, após um período, onde ele, sem ter atingido sua afiliação intelectual ou institucional, desiste tanto do curso como da universidade; o primeiro ano, para esse autor, é o mais crítico de todos.

Consultando a literatura, identificamos que existe uma fronteira esmaecida entre os termos exclusão e evasão. Muitos autores referemse a processos de exclusão, quando falam do abandono da universidade, frequentemente relacionados às dificuldades de permanência de estudantes ingressos pela política de ações afirmativas. Ou seja, mesmo que as universidades tenham avançado ampliando acesso para negros, indígenas e oriundos de escolas públicas, a debilidade ou inexistência de programas que visam apoiar esses segmentos, funcionaria como fatores que promovem a sua evasão/exclusão. A premissa não é absurda, mas dados iniciais, acerca de resultados e abandono entre cotistas, não parecem reforçar essa ideia para a qual já existe um discurso prévio à espera de dados, mesmo parciais, ou meras opiniões para se justificar. Essas vozes referem-se, insistentemente, a condições de permanência insuficientes, pois "a massificação deste nível de ensino não é sinônimo de igualdade de acesso para todos os jovens continuando a registrar-se acentuadas disparidades" (ALMEIDA et al. 2006, p. 508), afirmativa com a qual também concorda Silva (2003), dentre outros.

É importante considerar aqui a inversão proposta por Piotto (2008), quando essa autora defende que a pesquisa deve buscar as condições que são reunidas e que resultam na longevidade escolar de estudantes de origem popular. A exemplo do que fez Lahire (1997), quando se debruçou sobre trajetórias escolares improváveis, contrariando a lógica reprodutivista, que entende as dificuldades dos estudantes de origem popular como resultando direta e necessariamente das condições socioeconômicas e culturais de suas famílias de origem, ou a esses fatores atribui seu eventual fracasso.

Nem a reprodução, nem a ideia de transmissão podem refletir a ação vigorosa e altamente complexa de aprendizagem e reconstrução 
individual e, ao mesmo tempo social, que resulta na diversidade de percursos dos estudantes de origem popular. Piotto (2007) apresenta também os bons resultados de estudantes cotistas, objeto de seu trabalho de doutorado. Nunca é demasiado lembrar que o abandono dos estudos superiores não é fato que atinja exclusivamente uma dada população e, como afirmado anteriormente, tampouco prerrogativa de estudantes de origem popular. As universidades que adotaram algum tipo de sistema de reserva de vagas, mas não apenas elas, precisam manter e apresentar regularmente para a sociedade dados sistemáticos acerca da destinação de todos que nela ingressam, e, se possível, desenvolver alguma forma de acompanhamento de sua inserção no mundo do trabalho, nos anos que se seguem à obtenção do diploma. Aqui, pesquisa e amplo debate social precisam convergir.

Se a evasão, considerada como classe geral, significa uma desistência do estudante que sai da universidade sem concluir o curso, para Pereira (1995) "existem categorias que podem ser observadas, como abandono, cancelamento a pedido, cancelamento pela universidade e transferência para outra instituição"; segundo ele, "ainda podemos identificar outra nuance na evasão: quando o aluno migra de um curso ou área para outro". Nesses casos, propõe o autor considerar essa mudança como flutuação ou mobilidade que se dá como consequência de um possível amadurecimento pessoal do estudante, não sendo possível então, compreender esse tipo de evasão como "problema", mas resultado de uma busca.

De um ponto de vista técnico, evasão ainda pode ser entendida como evasão anual média e evasão total. A evasão anual média tem como objetivo mensurar a porcentagem dos estudantes matriculados num sistema de ensino, IES (Instituições de Educação Superior) ou curso, que não se formaram e não se matricularam no semestre ou ano posterior. A evasão total, também chamada de índice de titulação, mede a quantidade de estudantes que cursaram uma IES ou sistema de ensino, mas não conseguiram o diploma. (REIS FILHO et al., 2007) A evasão também pode ser tardia ou imediata, resultando de motivações distintas para a evasão. (SANTOS; BARROS, 1994) 
A dúvida pela continuidade também constitui uma problemática correlacionada com a evasão estudantil. Dias (1995) aponta dois tipos de dúvidas na continuidade e interrupção do curso, chamados de sentimento de dúvida e dúvida real. O sentimento de dúvida caracteriza-se pela insatisfação, questionamentos relativos ao curso, mas que não apresenta uma tomada de decisão imediata. Na dúvida real, o estudante se sente movido a tomar uma decisão sobre a continuação ou não do curso. A dúvida da continuidade desencadeia o prolongamento ou a desistência do curso, pois a entrada na universidade não garante o êxito educacional do estudante. $\mathrm{O}$ ensino superior apresenta uma forma de ensinoaprendizado diferente da que o estudante estava acostumado na escola. Essas diferenças podem fazer surgir o sentimento de insegurança com relação à vida universitária e à futura profissão.

Num estudo publicado em 2007, Beaupère et al. (2007, p. 16) aborda a dificuldade conceitual ligada ao tema da evasão. Diz a autora:

Nós levantamos quatro denominações que são importantes precisar e alocar em seus contextos específicos. Os termos 'desengajamento' e 'fracasso' remetem, implicitamente, ao mau funcionamento do ensino; é uma das reações possíveis ao ambiente e às suas contingências. Os termos 'abandono' e 'desistência' parecem mais ligados a decisões individuais. Estas diferentes terminologias não são neutras e subentendem fatores diferentes para o abandono dos estudos superiores.

As opiniões desses autores chamam nossa atenção para a não neutralidade das palavras utilizadas nesse campo, na medida em que elas remetem à observação diferenciada de seus antecedentes e até, acrescentamos, do seu desenvolvimento.

No caso brasileiro, além da seleção oficial para a entrada na educação superior, seja através de exames vestibulares ou através do Exame Nacional do Ensino Médio (ENEM) outra seleção, ou talvez outras operem de forma oficiosa. Essas seleções referem-se à organização dos currículos; à hierarquia socialmente estabelecida entre os diferentes tipos de diplomas concedidos pelas universidades; às dificuldades 
encontradas pelos estudantes para responder, de forma adequada, às exigências dos professores; às competências voltadas para as tarefas intelectuais efetivamente conquistadas antes da entrada na universidade e a aspectos concorrentes, como casamento e filhos, especialmente para estudantes do sexo feminino, e trabalho, para ambos os sexos.

No caso de estudantes que deixam a Universidade, em função da necessidade de trabalhar ou de se ocupar dos filhos, temos aí um "tipo" de saída, que, para muitos, é vivida como uma espécie de adversidade da vida, pois conhecem a importância da longevidade escolar com obtenção de diploma, como fator de preparação intelectual e mobilidade social. No cotidiano da sala de aula, são inúmeras as histórias desse tipo entre estudantes mais velhos e que retornam, por vezes, muitos anos depois, em busca de continuar sua formação acadêmica.

O Observatoire de La Vie Étudiante, estrutura do Ministério da Educação da França, que pesquisa diferentes aspectos da condição estudantil, dispõe de estudos específicos voltados especialmente para a compreensão das vicissitudes de jovens que tentam conciliar estudo e trabalho. Em um desses relatórios (BÉRIAL, 2007), entre outros temas, é avaliado o impacto da duração semanal dessa atividade sobre o sucesso escolar dos estudantes. O relatório conclui que continuidade e conclusão de um curso universitário são prejudicados ou ameaçados por investimento em tempo de trabalho, acima de 16 a 20 horas semanais, índices que acompanham uma curva também crescente da taxa de fracasso e abandono dos estudos.

O trabalho, buscado por esses jovens como um fator de autonomia e/ou independência econômica em relação a suas famílias, concorre fortemente com a obtenção de um diploma, fragilizando suas trajetórias universitárias e os tornando perdedores nessa corrida. Entretanto, mesmo o trabalho, como fator a ser considerado no insucesso e eventual desligamento dos estudos superiores, deve ser pensado no âmbito da vida universitária: a existência de trabalhadores estudantes não deveria ser prevista de tal modo que as trajetórias desse segmento fossem 
contempladas com medidas especiais que facilitassem a conclusão do ciclo universitário?

Além da perspectiva macro de análise em torno da evasão, é possível abrir as lentes da observação para encontrar, em detalhes do cotidiano da vida em universidades, se não motivos, mas condições sutis que, reunidas, fazem parte do percurso até o abandono completo dos estudos. Diz Felouzis (1997, p. 94):

[...] a organização universitária é, em grande parte, implícita, o que dá aos primeiros passos dentro da universidade o aspecto de uma corrida de obstáculos na qual sobrevivem apenas os mais dotados do ponto de vista escolar e aqueles que conseguem decodificar, antes dos outros, a coerência geral da instituição e do currículo.

Um antídoto em relação ao perigo dos "implícitos" é aumentar o tempo de permanência dos estudantes no espaço da universidade, como alerta Coulon (2008). Quanto mais tempo passar o estudante nesse ambiente, maiores serão suas chances de compreender o funcionamento desse mundo, suas regras, seus limites, suas exigências e possibilidades. Mesmo a participação em eventos não diretamente relacionados às aprendizagens acadêmicas é importante nesse percurso que leva da admissão ao diploma.

Sendo o abandono mais provável ao longo do primeiro ano universitário, e amplamente aceita a compreensão acerca da centralidade da afiliação e da aculturação aos códigos da universidade, o olhar dos gestores e pesquisadores, ao menos na França, recai sobre a importância do acolhimento e da orientação acadêmica aos ingressantes, para tentar garantir a passagem do métier de aluno, ao métier de estudante. Entretanto, o que parece ser uma modalidade de prevenção é criticado como uma espécie de "secundarização"6 da educação superior (BEAUPÈRE, 2007), que protege excessivamente, dificultando a autonomia e definitiva inclusão do estudante na vida acadêmica.

6 O ensino médio, em francês, é chamado de ensino secundário, como antes, no Brasil. 


\section{JUVENTUDE CONTEMPORÂNEA E VIDA UNIVERSITÁRIA}

Sem a intenção de tratar, nos limites de poucas páginas, questão tão vasta, trazemos alguns elementos que possam ajudar essa discussão a melhor se desenvolver, pela ampliação de horizontes que provoca.

Um fato importante do nosso tempo é o atardamento da emancipação da juventude e a fluidez dos critérios sociais utilizados para marcar a entrada definitiva na vida adulta. As mudanças desenvolvimentais não seguem mais a perspectiva linear de eventos marcadores, acontecendo em idades que se sucedem ao longo do tempo de vida de uma pessoa. Hoje, é possível que um jovem deixe o sistema de ensino para trabalhar, estabeleça relação com um parceiro, tenha um filho e, depois, retorne ao mundo da educação para completar seus estudos, mesmo que abandonar os estudos tenha como consequência acessar empregos precários ou menos rentáveis. A estabilidade almejada e pela qual se lutava, especialmente nos setores médios da população, como condição para a constituição de uma família, não parece mais fazer parte de parcela significativa das culturas juvenis.

A saída da casa dos pais é outra situação sujeita a muitas mudanças. O prolongamento do tempo de estudos, característica dos países industrializados, a partir de meados do século XX, altera o curso de práticas usuais relativas à emancipação: hoje, jovens entre 18 e 25 anos de idade encontram-se em pleno período de formação, muito deles ainda convivendo com suas formações familiares originais. No caso de qualquer eventualidade relativa aos estudos, como o desinteresse pela formação que seguem, eles contam com essa retaguarda de proteção da família, talvez permitindo que experimentem novas opções de currículo ou que abandonem simplesmente aquele onde se encontravam, com menos inseguranças quanto à sua manutenção.

Pais (2005) vai identificar na juventude portuguesa trajetórias lineares da escola para o trabalho que tendem a se transformar em trajetórias ioiô: tanto para os que vão cedo para o mercado como para aqueles que se encontram em universidades, a necessidade de qualificação exige o retorno à escola para novos períodos formativos, o que pode 
adiar muito decisões relativas à vida pessoal e independência do ponto de vista do domicílio. Todas essas modificações relativas à juventude e suas intrincadas relações com a educação, o mundo do trabalho, a família e aspectos do desenvolvimento pessoal não podem deixar de participar da relativa instabilidade juvenil frente à sua permanência na educação superior.

Por outro lado, as relações das novas gerações com o mundo baseiam-se na instantaneidade, na interatividade à distância, permitida pela comunicação sem fio, o que altera hábitos e expectativas relativas ao modo de conhecimento mais adaptado às novas tecnologias. Seria esse mundo também frequentado pelos professores e considerado quando professores planejam suas estratégias educativas? É Canclini (2009, p. 148) quem afirma:

As diferenças geracionais entre professores e alunos não se manifestam somente no manejo de conteúdos informativos, mas também nos estilos de acesso e uso da informação. Quando queremos preparar um trabalho, procuramos a informação em livros, revistas ou na internet?

Esse autor chama a atenção para uma espécie de "presenteísmo" - a perda do sentido histórico e utópico (CANCLINI, 2009), que impera nas relações da juventude com a vida e em suas relações pessoais e institucionais. São exatamente os jovens que experimentam de forma severa a instabilidade profissional e a exposição a riscos pouco previsíveis, permitindo certo "descolamento" da perspectiva histórica que leva muitos à desesperança e a um sentimento de que "o esforço não vale à pena”. Isso vai atingir inclusive suas relações com a educação provocando "[...] uma reorganização radical do que vínhamos chamando de modernidade [...]”. (CANCLINI, 2009, p. 150)

Frente a um vasto mundo informacional e acessível, como o ensino ainda professoral adotado em universidades em todo o mundo é sentido por uma parcela dessa juventude que busca espaço nelas para em seguida descartá-la? Que tipo de antena necessita a educação superior para se conectar aos novos tempos vividos pela juventude que a procura? 
Estariam essas mudanças implicadas no abandono dos estudos superiores? De que forma? Como sintonizar esses dois mundos que parecem em curso de um divórcio onde a linguagem comum foi rompida?

A relativa rigidez em que vivem as universidades pode estar em dissonância com a instabilidade e flutuação do mundo onde circulam as novas gerações. Isso pode ter consequências importantes do ponto de vista curricular. Para Ribeiro (2003), a evasão seria um fenômeno que revela uma crítica à universidade que não consegue se estruturar de modo compatível com novos modos de comportamento. Para ele, a evasão pode ser vista como uma reação às fronteiras disciplinares que permeiam o que a instituição oferece a seus estudantes. A forma como cada área se delimita até espacialmente e a especialização extrema do saber já não dão mais conta das necessidades humanas relativas ao conhecimento. A universidade não pode restringir seu espaço de liberdade, criação e cultura, mas deve promover espíritos inquietos e não ter como objetivo central a emissão de diplomas que dão acesso linear a uma profissão; sua função é apresentar os múltiplos saberes que extrapolam fronteiras, propõem novas áreas de friç̧ão entre eles e derivam da inovação. (RIBEIRO, 2003)

\section{PARA CONCLUIR}

O tratamento adequado desse tema não pode se restringir ao campo da educação. Ele exige aproximação de saberes originários de outras áreas do conhecimento, especialmente aquelas que discutem mudanças no mundo do trabalho, a distinção contemporânea entre mundo analógico e digital que cria novas questões intergeracionais e, sobretudo, estudos sobre juventude que discutam o que significa emancipação para as novas gerações. Evitando toda individualização do problema, na medida em que, sair da universidade sem um diploma, não é ato circunscrito ao âmbito da família ou do jovem que toma essa decisão, se é que podemos chamar essa saída de "decisão". Talvez ela seja adotada como única alternativa e seja gestada antes mesmo da entrada do jovem na vida universitária. 
As contribuições existem, são variadas e, mesmo quando não tratam diretamente da questão da evasão, provêm reflexões, aportes e interrogações sobre a juventude no mundo contemporâneo que a instituição universitária tem sido refratária em considerar, deixando para as tabelas e quadros estatísticos a tarefa de apenas mostrar a existência do fenômeno, sem mobilizar energias para lidar, sinceramente, com o problema.

Encaminhar a evasão na educação superior, em todo o mundo, considerada aqui, como tema de pesquisa e objeto social, deve resultar de profundas mudanças nas instituições universitárias, em sua relação com o saber, na busca de sua legitimidade, e de um novo tratamento, do ponto de vista da qualidade, das populações de jovens estudantes que nelas entram todos os anos.

\section{REFERÊNCIAS}

ALMEIDA et al. Acesso e Sucesso no Ensino Superior em Portugal: questões de gênero, origem sócio-cultural e percurso acadêmico dos alunos. Psicologia: reflexão e crítica, v. 19, n. 3, p. 507-514, 2006.

BEAUPÈRE, Nathalie et al. L'abandon des études supérieurs. Paris : La Documentation Française, 2007.

BÉRAIL, M. Laurent. Le Travail des Étudiants. Paris, 2007. Le Travail des Étudiants. Avis et Rapport du Conseil Économique et Social. Disponível em: <http://www.ove-national.education.fr/index. php?lang $=$ en\&page $=$ resultat_recherche.php\&super_type $=$ notrapp $>$. Acesso em: 22 maio 2010.

CANCLINI, Nestor Garcia. Diversidade e direitos na interculturalidade global. Revista Observatório Itaú Cultural / OIC, n. 8, p. 144-152, 2009.

COULON, A. A condição de estudante: a entrada na vida universitária. Salvador: EDUFBA, 2008.

DIAS, E. T. Dúvida da continuidade dos estudos universitários: uma questão adolescente. 1995. Dissertação (Mestrado em Psicologia) - Instituto de Psicologia, Universidade de São Paulo, São Paulo, SP, 1995. Orientadora: Prof. ${ }^{a}$ Dr. ${ }^{a}$ Vera Lúcia Fava. 
FELOUZIS, G. Les Étudiants et la sélection universitaire. Revue Française de Pédagogie, n. 119, p. 91-106, 1997.

LAHIRE, B. O sucesso escolar nos meios populares: as razões do improvável. São Paulo: Ática, 1997.

MOEHLECKE, Sabrina. Avaliação institucional no ensino superior: como acompanhar a trajetória dos estudantes de graduação? In: COLÓQUIO IBERO-AMERICANO DA ASSOCIAÇÃO NACIONAL DE POLÍTICA E ADMINISTRAÇÃO DA EDUCAÇÃO, 1., 2007, Porto Alegre. Anais... Porto Alegre: ANPAE, 2007.

PAIS, José Machado. Ganchos, tachos e biscates: jovens, futuro e trabalho. Lisboa: Ambar-Idéias no Papel, S.A., 2005.

PEREIRA, J. T. V. Uma contribuição para o entendimento da evasão um estudo de caso: Unicamp. Campinas, SP: Pró-reitoria de graduação da Unicamp, 1995. p.23-32.

PIOTTO, Débora Cristina. As exceções e suas regras: estudantes das camadas populares em uma universidade pública. 2007.361 f. Tese (Doutorado em Psicologia Escolar e do Desenvolvimento Humano) - Instituto de Psicologia, Universidade de São Paulo, São Paulo, SP, 2007. Orientadora: Prof. ${ }^{a}$ Dr. ${ }^{a}$ Maria Clotilde Rossetti-Ferreira . Trajetórias Escolares Prolongadas nas Camadas Populares. Cadernos de Pesquisa, v. 38, n. 135, p. 701-727, set./dez. 2008.

RIBEIRO, Renato. Janine. A Universidade e a vida atual - Fellini não via filmes. Rio de Janeiro: Campus, 2003.

SANTOS, J.L.F.; BARROS, L.F. Cadernos de Estudos da Evasão. Núcleo de Apoio aos estudos de graduação - USP. São Paulo, 1994.

SILVA FILHO, Roberto Leal Lobo et al. A Evasão no Ensino Superior Brasileiro. Cadernos de Pesquisa,Rio de Janeiro, v. 37, n. 132, 2007.

SILVA, Cidinha da. Ações Afirmativas em Educação: um debate para além das cotas. In: SILVA, Cidinha da (org.) Ações afirmativas em educação: experiências brasileiras. São Paulo: Summus, 2003. 


\section{Posfácio ${ }^{1}$}

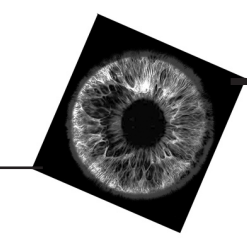

ALAIN COULON

A importância deste livro é evidente para um professor universitário francês. De fato, em 1989, momento em que a França vivia a última fase de massificação da sua população universitária ${ }^{2}$, o ministro da Educação decidiu criar, em âmbito nacional, um Observatório da Vida Estudantil (OVE), que teria, como missão, realizar pesquisas voltadas para a sistematização de informações, detalhadas e objetivas, sobre a condição de vida dos estudantes, bem como de sua relação com os estudos e percurso acadêmico, com a finalidade de iluminar o debate público e contribuir para a tomada de decisões.

1 A tradução desse texto é da Profa. Ana Maria Freitas Teixeira (UFS).

2 A população de estudantes na França experimentou um crescimento contínuo, desde meados da década de 1960, mas, entre 1985 e 1995, esse crescimento se intensifica e o total de universitários passa de 1,3 para 2,1 milhões nesse período. Desde 1995, este número mostra-se relativamente estável. 
Assim, a cada três anos, o OVE realiza uma grande pesquisa nacional (em amostra representativa de mais de 25.000 estudantes), sobre diferentes temas: habitação, financiamento dos estudos, uso do tempo, percurso acadêmico, trabalho assalariado, atividades culturais e associativas e origem social. O OVE realiza, igualmente, outros estudos temáticos mais específicos, a exemplo da situação dos estudantes estrangeiros, inserção profissional dos diplomados, engajamento em associações ou condições de vida daqueles economicamente vulneráveis. A produção regular dessas informações permitiu acompanhar a evolução da condição estudantil ao longo desses vinte últimos anos. A publicação sistemática dessas investigações e estudos, em escala nacional, permitiu a comparação internacional de dados, particularmente entre países europeus.

Desde então, muitas universidades francesas criaram um OVE próprio, com objetivos vinculados ao estudo das características de sua população estudantil, a exemplo de: evolução, condições locais de vida, êxito diferencial dos estudantes, segundo o currículo adotado, modos de vida, inserção profissional, com a finalidade de favorecer uma gestão séria, inteligente e amadurecida das instituições.

Os temas tratados neste livro apresentam, de forma clara, interrogações e interesses comuns entre a pesquisa sobre o ensino superior, desenvolvida, atualmente, tanto no Brasil quanto na França. A leitura dos artigos publicados nesta obra permite identificar cinco eixos que compõem um programa de estudo e reflexão e uma agenda de trabalho a ser desenvolvida no futuro:

- o primeiro eixo trata da diversidade social no ensino superior, a igualdade das chances, a chegada de novos públicos à universidade ou de estudantes com necessidades educacionais especiais. Procura identificar as diferentes dimensões sociais e pedagógicas desse fenômeno e seu impacto sobre o funcionamento da universidade.

- o segundo eixo, no meu ponto de vista, trata da integração dos estudantes no ambiente universitário, aquilo que eu chamei de afi- 
liação intelectual ${ }^{3}$ dos que ingressam no primeiro ano e que implica a aprendizagem dos múltiplos códigos dissimulados, nunca ou raramente explicitados pelos professores, nas práticas do ensino superior. Trata-se, para o novo estudante, de aprender um universo novo, assimilar novas regras do trabalho intelectual: práticas de leitura, de escrita, de expressão oral, de pesquisa documental que, em seu conjunto, exigem trabalho intelectual intenso (em tempo integral, se possível), perseverança, paciência e estímulo. Esta "socialização intelectual" é particularmente capital para os "novos" públicos estudantis: a conquista da afiliação é uma condição de sobrevivência na universidade.

- o terceiro eixo parece se configurar em torno da vida cultural e social na universidade, considerada como fator de integração. De fato, muitas pesquisas demonstram que as condições de sucesso dos estudantes acadêmicos não se limitam às dimensões pedagógicas e cognitivas, mas dependem, igualmente, do seu clima social e cultural interno. A universidade, além da sua evidente missão de aprendizagem intelectual e profissional de alto nível, deve ser, simultaneamente, um lugar de convivência.

- o quarto eixo é relativo à emergência de novas instituições na paisagem do ensino superior brasileiro, instaladas em cidades e territórios mais afastados dos principais centros urbanos. Eu considero que os desafios colocados para essas universidades ou antenas universitárias "periféricas” são múltiplos. Se quisermos evitar que estas universidades sejam consideradas como instituições margi-

3 Sobre essa questão, ver Alain Coulon. A condição de estudante: $a$ entrada na vida universitária. Salvador: EDUFBA, 2008.

4 Em francês, a expressão "antenne" é utilizada para designar "um posto avançado em ligação com um centro", segundo o Dictionnaire Le Grand Robert. No caso da educação superior francesa, caracteriza-se por ser um estabelecimento de pequeno porte que amplia para o interior as ações de uma universidade, frequentemente oferecendo apenas o primeiro ciclo e poucas alternativas de formação; além de pequenos, esses espaços são menos equipados em termos de laboratórios, bibliotecas, equipamentos e contam com professores menos qualificados. 
nais e estigmatizadas é imperativo cuidar da qualidade dos currículos, do corpo docente, dos equipamentos e das condições da vida estudantil. A França, bem como os países que passaram por uma fase de massificação das universidades, desenvolveu, ao longo dos últimos trinta anos, esse tipo de específico de instituição, implantada em pequenas cidades do interior. Algumas, em particular, alcançaram bom desempenho, outras permanecem pouco atrativas e hoje se coloca em questão a sua sobrevivência.

- por fim, o último eixo vincula-se à diversificação do currículo universitário e à interdisciplinaridade como um modo operatório para aumentar as chances de inserção profissional. A universidade contemporânea, adaptada às novas condições econômicas e às novas ocupações, numa economia cada vez mais apoiada no conhecimento, impõe a diversificação das abordagens curriculares e não se limita a ofertar currículos organizados segundo uma lógica conservadora. A visão disciplinar do conhecimento perdeu espaço nos dias atuais: a complexidade de nossas sociedades contemporâneas convida à construção de currículos que obedeçam a novos paradigmas de formação, fundados sobre realidades tecnológicas e sociais, que exigem, na sua formulação, a mobilização de vários campos de conhecimento.

A leitura dos artigos deste livro indica que os autores utilizam, sobretudo, abordagens qualitativas. A experiência de pesquisas francesas e internacionais demonstra que a utilização simultânea de abordagens quantitativas e qualitativas é desejável, para dar conta de todas as dimensões dos complexos fenômenos que atuam na vida universitária.

Por outro lado, os artigos que integram a presente obra tratam, tanto dos estudantes e dos problemas que eles encontram ao longo de suas trajetórias, como de questões institucionais. Essas duas vertentes/ possibilidades, ainda que sejam fundamentais, não podem apreender totalmente as problemáticas do campo universitário. Será necessário, no futuro, desenvolver pesquisas e estudos sobre o mundo dos professores, suas práticas pedagógicas, suas relações com os estudantes e sua im- 
plicação institucional e social. Com efeito, a profissão acadêmica sofrerá evoluções, notadamente no âmbito da articulação entre ensino e pesquisa, mas também na esfera da valorização do ato pedagógico, da formação dos docentes da educação superior, da avaliação de suas atividades, inclusive aquelas de caráter pedagógico.

A massificação do ensino superior se faz acompanhar de mutações sociais, científicas e tecnológicas, que produzem impactos tanto sobre o ensino quanto na pesquisa. Um exemplo flagrante é a irrupção das novas tecnologias da informação e da comunicação que transformam a paisagem universitária. O Brasil, como país emergente, necessita de uma universidade vigorosa, para apoiar seu desenvolvimento econômico e social futuro. Isso implica formar novos quadros superiores e médios a serviço desse desenvolvimento. Por essa razão, a universidade se tornará um ator central na sociedade brasileira. Será necessário, provavelmente, que ela continue a diversificar a oferta de formação e os públicos que beneficia. Nessa perspectiva, a França se colocou o objetivo de atingir, até 2012, a marca de 50\% de diplomados no ensino superior entre aqueles que se encontram na faixa etária de 17 a 33 anos. Os esforços orçamentários, recentes e contínuos, e as reformas estruturais em curso autorizam nossa esperança de atingir essa meta, uma vez que, em 2005, esse índice alcançava 41\% e, em 2008, 44,7\%.

O fenômeno da massificação da educação superior altera o cenário da universidade, seus programas e a oferta de formação, seus públicos, sua relação com a demanda social e sua pedagogia. A massificação confere novas missões à universidade, em termos do sucesso acadêmico dos estudantes de origem popular e de sua inserção profissional. Devemos, então, "inventar" uma universidade que se adapte continuamente aos seus públicos e à demanda social, no sentido mais amplo do termo, sem, contudo, renunciar à sua missão histórica como lugar da produção e difusão de conhecimentos.

É por isso que um dispositivo como o OVE torna-se tão primordial: é necessário observar e analisar a universidade permanentemente. Os efeitos da massificação são sempre múltiplos e podem ser inespera- 
dos, tanto positiva como negativamente. Realizar pesquisas sistemáticas sobre o ensino superior é, assim, um caminho incontornável para acompanhar a orientação, formação e inserção profissional de todos os públicos estudantis. É necessário seguir e estudar as mudanças consideráveis que se produzirão ao longo dos próximos anos do desenvolvimento brasileiro. Essa é a condição sine qua non para evitar avançar às cegas.

Paris, 2 de maio de 2010. 


\section{Sobre os Autores}

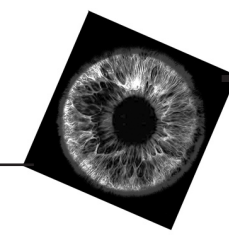

ALLAN JEFFREY VIDAL MAIA

Graduado em Psicologia pela Universidade Federal da Bahia.

Vinculado ao Centro de Referência Especializado de Assistência Social

do município de Olindina - BA. E-mail: allanjvmster@gmail.com

ALAIN COULON

Professor da Universidade Paris 8. Diretor do Departamento

de Estratégia para a Educação Superior e Inserção Profissional

do Ministério do Ensino Superior e Pesquisa da França.

E-mail: a.coulon@noos.fr

AMANDA ALMEIDA ALVES

Graduada em Psicologia pela Universidade Federal da Bahia.

E-mail: mann_alves@hotmail.com

ANA MARIA DE OLIVEIRA URPIA

Mestre e doutoranda em Psicologia pela Universidade Federal da Bahia.E-mail: aurpia@bol.com.br 
ANA MARIA FREITAS TEIXEIRA

Doutora em Ciências da Educação pela Universidade de Paris 8.

Professora Adjunta da Universidade Federal de Sergipe vinculada ao Programa de Pós-Graduação em Educação.

ARLETE PiRES De CARVALHo E Figueiredo

Estudante do Instituto de Psicologia da Universidade Federal da Bahia.

AVA DA SILVA CARVALHO CARNEIRO

Mestre em Psicologia pela Universidade Federal da Bahia. Email:

avacarvalho@yahoo.com.br

CAMILA PEREIRA LISBOA

Graduada em Psicologia pela Universidade Federal da Bahia. E-mail: milalisb@gmail.com

CHRISSIE FERREIRA DE CARVALHO

Mestranda em Psicologia pela Universidade Federal da Bahia. E-mail: chrissieca@gmail.com

CIRO FREDERICO ARÃO DA SILVA OLIVEIRA

Graduado em Psicologia pela Universidade Federal da Bahia. E-mail: cirofrederico@yahoo.com.br

DJENANE BRASIL DA CONCEIÇÃO

Mestre em Psicossociologia de Comunidade e Ecologia Social pela Universidade Federal do Rio de Janeiro. Professora Assistente do Centro de Ciências e Saúde da Universidade Federal do Recôncavo da Bahia. E-mail: djenanebc@yahoo.com

FÁBIO NIETO LOPEZ

Doutorando em Psicologia pela Universidade Federal da Bahia.

E-mail: fabionieto@gmail.com

GABRIELA SOUZA COTRIM

Graduada em Psicologia pela Universidade Federal da Bahia. Email: gscotrim@hotmail.com 
GEORGINA GONÇALVES DOS SANTOS

Doutora pela Universidade de Paris 8. Professora Adjunta da Universidade Federal do Recôncavo da Bahia e pesquisadora do Conselho Nacional de Desenvolvimento Científico e Tecnológico. E-mail: georgina@ufrb.edu.br

ÍTALO MAZONI

Graduada em Psicologia pela Universidade Federal da Bahia. E-mail: italomazoni@gmail.com

JOANA PEREZ

Estudante de Psicologia em intercâmbio na Universidade Federal da Bahia em 2008.

JOSINEIDE VIEIRA ALVES

Doutorado. Universidade Federal do Recôncavo da Bahia.

E-mail: joalves99@hotmail.com

JULIANIN ARAÚJO SANTOS

Graduação em Psicologia pela Universidade Federal da Bahia. Bolsista de Apoio Técnico a Pesquisa do Conselho Nacional de Desenvolvimento Científico e Tecnológico. Email: julianinaraujo@ yahoo.com.br

JULINI ARAÚJO SANTOS

Graduação em Psicologia pela Universidade Federal da Bahia.

Residente do Programa de Residência Multiprofissional de Saúde da Família da Escola Bahiana de Medicina e Saúde Pública.

E-mail: juliniaraujosantos@yahoo.com.br

KARLA GEYB DA SILVA QUEIROZ

Estudante de Psicologia Centro de Ciências e Saúde da Universidade Federal do Recôncavo da Bahia. E-mail: karla_geyb@hotmail.com

LÉLIA CUSTÓDIO DA SILVA

Mestranda em Psicologia pela Universidade Federal da Bahia. E-mail: leliacustodio@yahoo.com.br 


\section{LETÍCIA SILVEIRA VASCONCELOS}

Mestranda em Psicologia do Desenvolvimento no Programa de Pós-graduação em Psicologia da Universidade Federal da Bahia e Pesquisadora do Observatório da Vida Estudantil.

E-mail: leticiasvasconcelos@gmail.com

LUís ALBERTO MENEZES CERQUEIRA

Graduando em Psicologia na Universidade Federal da Bahia. Email: luisufba@yahoo.com.br

LUIZ FERNANDO CALAÇA DE SÁ JÚNIOR

Especialista em Gestalt-Terapia pelo Instituto de Gestalt-Terapia da Bahia. Psicólogo da Empresa Brasileira de Infraestrutura Aeroportuária. E-mail: lfcalaca@gmail.com

LUZIA MASCARENHAS DE ALMEIDA

Graduada em Psicologia pela Universidade Federal da

Bahia.E-mails: luziamascarenhas.ba@gmail.com ou lilamasc@yahoo. com.br

MARCELO NAVARRO

Psicólogo graduado pela Universidade Federal da Bahia. E-mail: marccelonavarro@hotmail.com

MARIA GORETTI F. C. PONTES

Mestre, Professora do Centro de Ciências e Saúde da Universidade Federal do Recôncavo da Bahia. E-mail: gorettipontes@ufrb.edu.br MATHEUS BATALHA MOREIRA NERY

Doutor em Psicologia pela Universidade Federal da Bahia. Professor da Universidade Tiradentes. E-mail: matheusbatalha@ig.com.br

NAOMAR DE ALMEIDA FILHO

Doutor em Epidemiologia pela University of North Carolina, bolsista 1 A de produtividade do Conselho Nacional de Desenvolvimento Científico e Tecnológico, reitor da UFBA até 31 de julho de 2010. E-mail: naomar@ufba.br 
SÔNIA MARIA ROCHA SAMPAIO

Doutora (UFBA) Pós-doutora (Paris 8). Professora Associada III, Pesquisadora da Universidade Federal da Bahia, Coordenadora do Observatório da Vida Estudantil UFBA/UFRB.E-mail: sampaios@ ufba.com

SUELI BARROS DA RESSUREIÇÃO

Doutoranda no Programa de Pós-Graduação em Psicologia pela Universidade Federal da Bahia. Professora assistente da UNEB. E-mail: suelibarros13@gmail.com

RAQUEL TRINCHÃO DE JESUS BAROUH TORRES

Graduada em Psicologia pela Universidade Federal da Bahia.

Servidora (assistente em administração) da Universidade Federal da Bahia.E-mail: rqbarouh@hotmail.com

RENATA MOREIRA DA SILVA

Mestranda em Psicologia pelo Programa de Pós-Graduação em Psicologia da Universidade Federal da Bahia. E-mail: renatamoreirapsi@yahoo.com.br

RITA DE CÁSSIA NASCIMENTO LEITE

Mestre em Psicologia. Professora do Curso de Psicologia do Centro de Ciências da Saúde da Universidade Federal do Recôncavo da Bahia.E-mail: rcnleite@ig.com.br 


\begin{tabular}{r|l} 
Formato & Colofão \\
Tipologia & Leitura News e leitura Sans 10/16 $\mathrm{cm}$ \\
Papel & $\begin{array}{l}\text { Alcalino } 75 \mathrm{~g} / \mathrm{m}^{2}(\text { miolo }) \\
\text { Cartão Supremo } 300 \mathrm{~g} / \mathrm{m}^{2} \text { (capa) }\end{array}$ \\
Impressão & $\begin{array}{l}\text { Edufba } \\
\text { Cian Gráfica } \\
\text { Capa e Acabamento }\end{array}$ \\
Tiragem & 400
\end{tabular}

